Doktori $(\mathrm{PhD})$ értekezés

\title{
KÁRPÁT-MEDENCEI ALMAFAJTÁK JELLEMZÉSE POMOLÓGIAI VIZSGÁLATOKKAL ÉS MIKROSZATELLIT ALAPÚ MOLEKULÁRIS MARKEREZÉSSEL
}

\author{
Király Ildikó
}

Témavezető: Dr. Tóth Magdolna, DSc

egyetemi tanár

Budapesti Corvinus Egyetem

Gyümölcstermő Növények Tanszék

Budapest

2013 


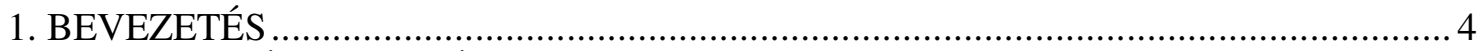

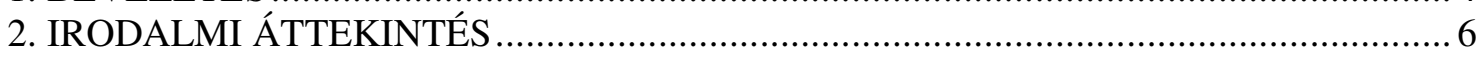

2.1. Régi almafajták szerepe a biodiverzitás megőrzésében ...................................... 6

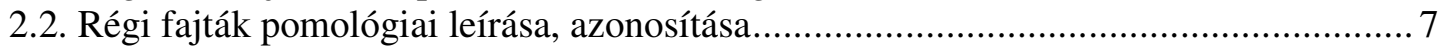

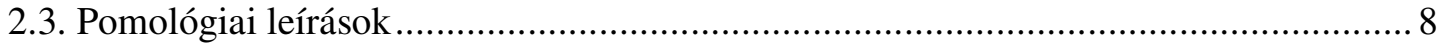

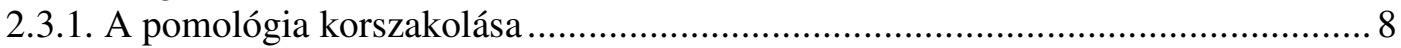

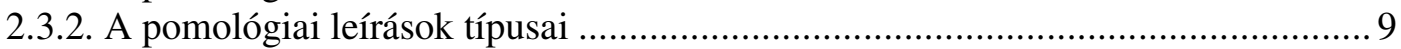

2.3.3. Pomológiai leíró módszerek..................................................................... 10

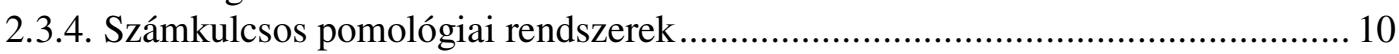

2.3.5. Almafajták rendszerezése a pomológiai müvekben ...................................... 11

2.3.6. Régi magyar fajtákra vonatkozó forrásmunkák a virágzásfenológia és morfológia

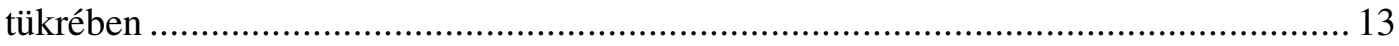

2.4. Mikroszatellit (SSR) markerek fejlesztése és alkalmazási lehetőségei almánál.......... 15

2.4.1. Mikroszatellit primerek fejlesztése ............................................................ 15

2.4.2. Mikroszatellit markerek alkalmazási lehetőségei............................................ 16

2.4.2.1. A génbanki gyüjtemények genetikai diverzitásának felmérésétől a

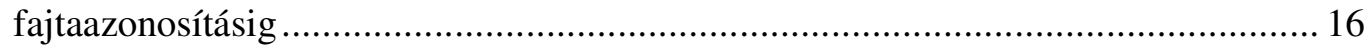

2.4.2.2. Rügymutációval létrejött fajták azonosításának nehézségei ........................ 20

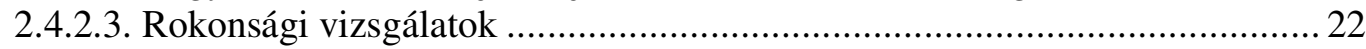

2.4.2.4. Filogenetikai vizsgálatok................................................................ 23

2.4.2.5. Az SSR markerek genetikai diverzitás vizsgálatokban való alkalmasságának összevetése egyéb molekuláris technikákkal .................................................... 25

2.4.2.6. Rezisztenciagének SSR markerezése................................................. 25

2.4.2.7. Egyéb (növekedéssel, gyümölcsminőséggel kapcsolatos) tulajdonságok SSR

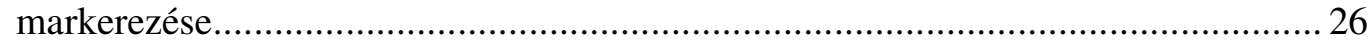

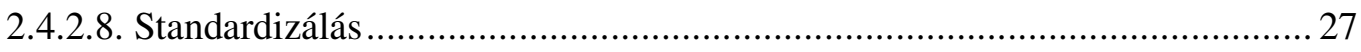

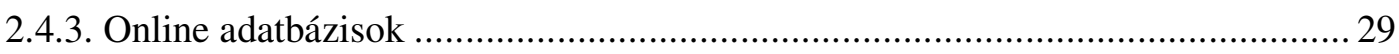

2.5. A morfológiai és a molekuláris jellemzések együttes alkalmazása ............................29

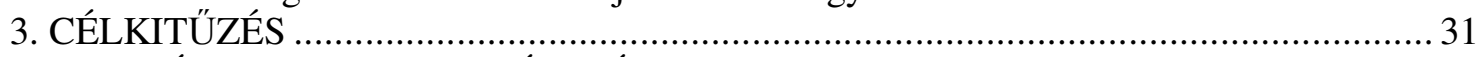

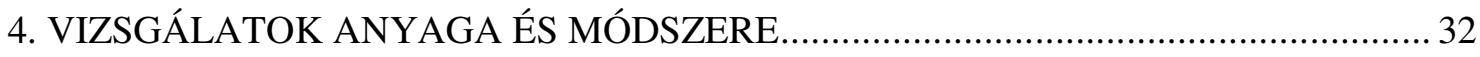

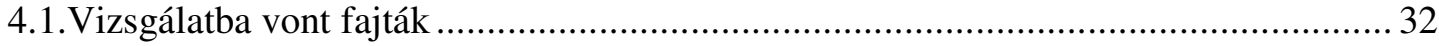

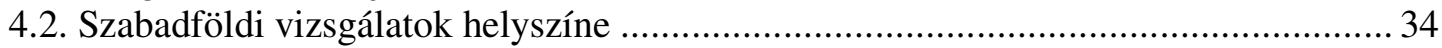

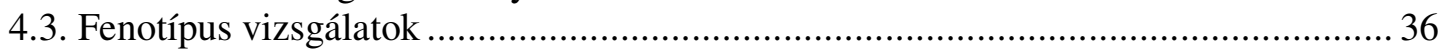

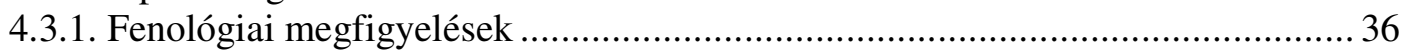

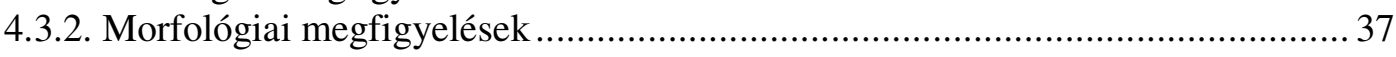

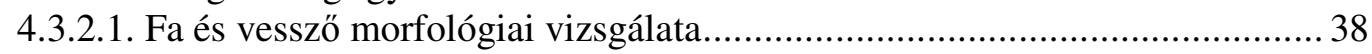

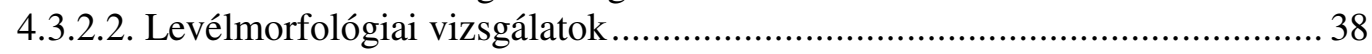

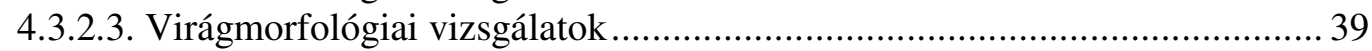

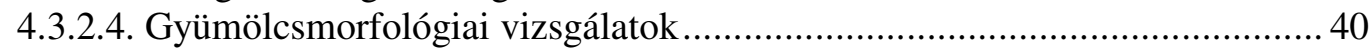

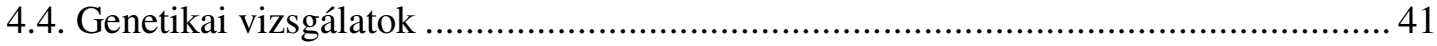

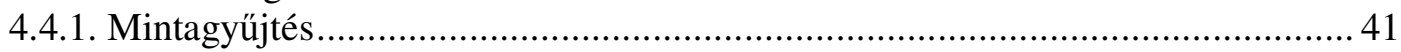

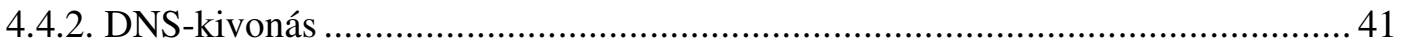

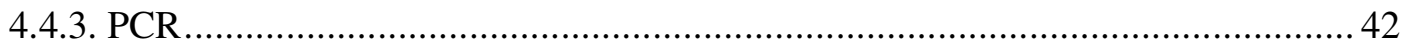

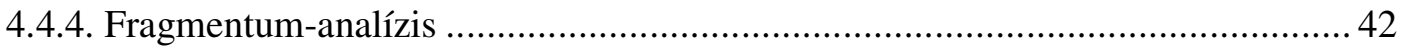

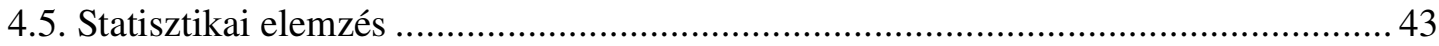

4.5.1. A morfológiai adatok statisztikai kiértékelése ............................................. 43

4.5.2. Az SSR fragmentumhosszok statisztikai kiértékelése .................................... 44

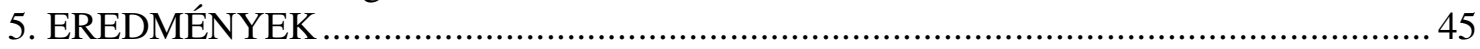

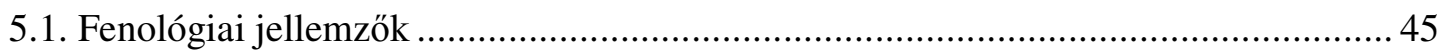

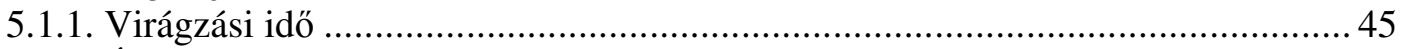

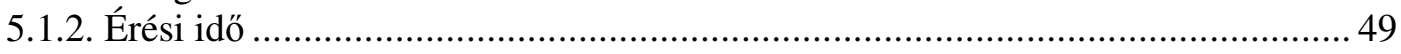




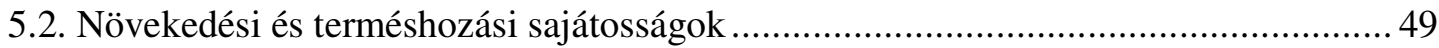

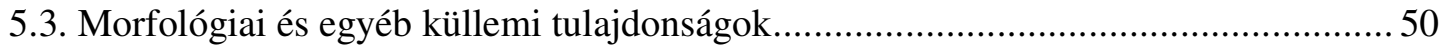

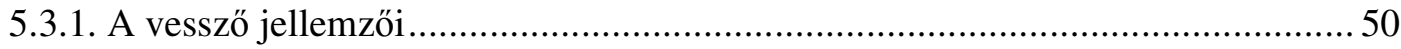

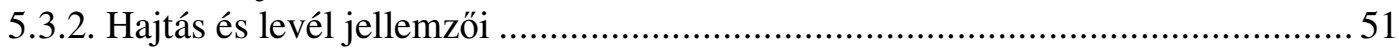

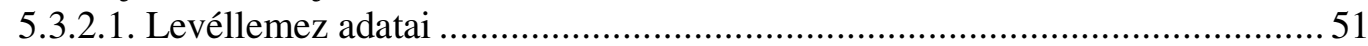

5.3.2.2. A hajtás és a levél egyéb jellemzői ........................................................... 56

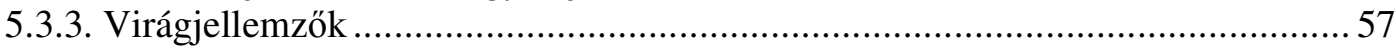

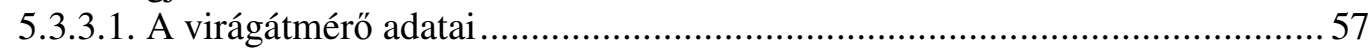

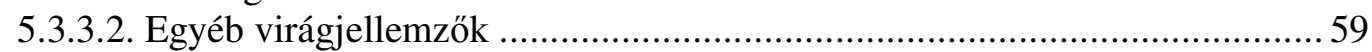

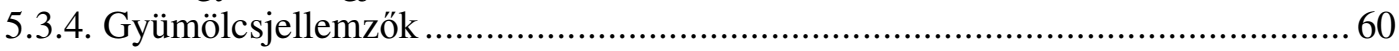

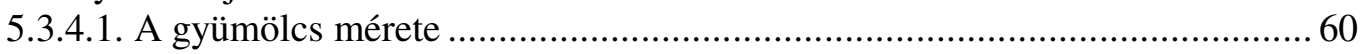

5.3.4.2. A gyümölcs alakja, a csésze- és kocsánymélyedés jellemzői .......................6 63

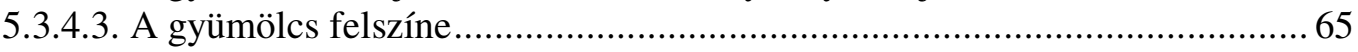

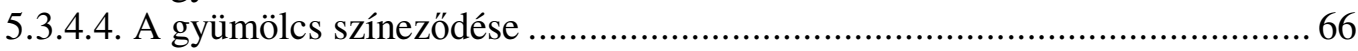

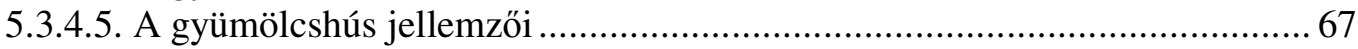

5.4. A fajták jellemzése a számkulcsos besorolásuk szerint ..........................................6 68

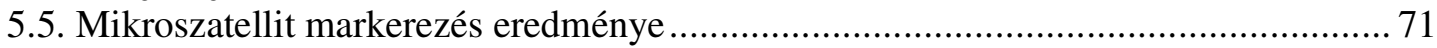

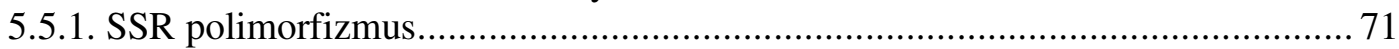

5.5.2. Fajtaazonosítás és a fajtacsoportok értékelése az allélösszetétel és klaszteranalízis

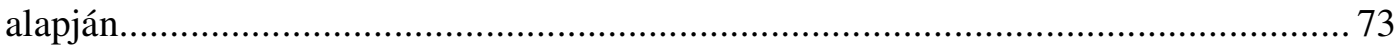

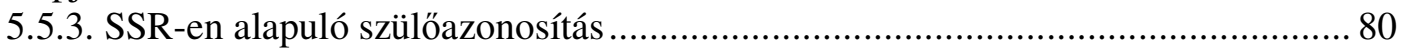

5.5.4. Korreláció a morfológia és a molekuláris vizsgálat között................................ 83

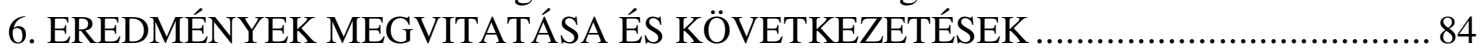

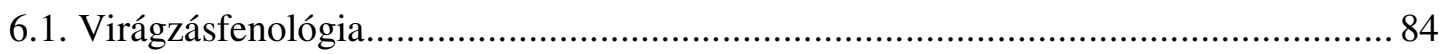

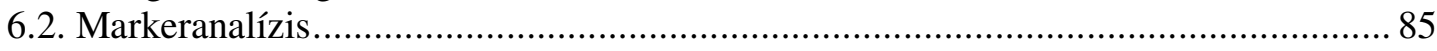

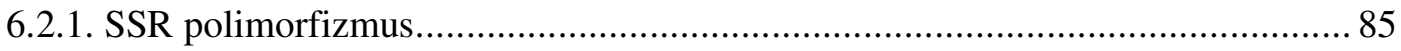

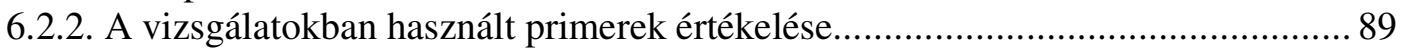

6.2.3. A fajták allélösszetétele, genetikai ujjlenyomata .......................................... 90

6.3. Fajtacsoportok, szinonimák, fajtaazonosság a morfológiai és a molekuláris vizsgálatok

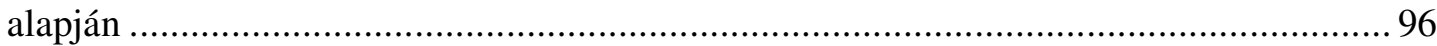

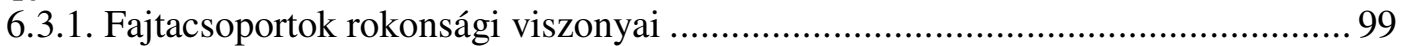

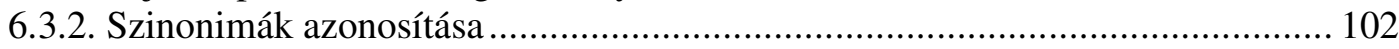

6.4. Az SSR markerek és az UPOV bélyegek alkalmassága a fajtaazonosítás során....... 107

6.5. A morfológiai és molekuláris adatok közti összefüggés .......................................... 108

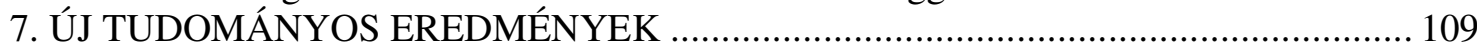

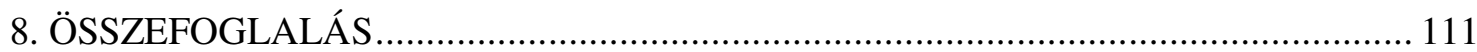

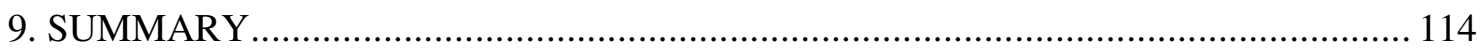

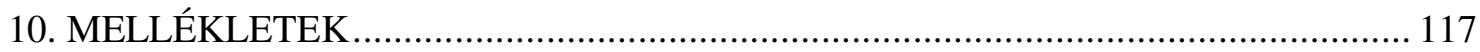

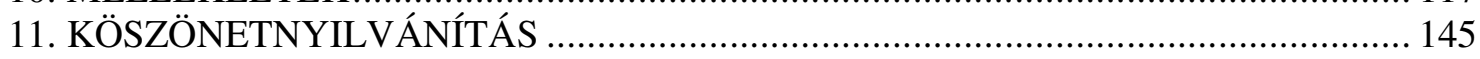




\section{Rövidítések jegyzéke}

AFLP=Amplified Fragment Length Polymorphism=amplifikált fragmentumhossz polimorfizmus

BEVOG-projekt =Beschreibung von Obstgenressourcen=Gyümölcs génforrások leírására irányuló projekt

CPVO=Community Plant Variety Office=Közösségi Fajtaoltalmi Hivatal

DUS= Distinctness, Uniformity, Stability= megkülönböztethetőség, egynemüség, állandóság

ECPGR=European Cooperative Programme for Crop Genetic Resources Network=Genetikai

Erőforrás Hálózatok Európai Együttmüködési Programja

EST-SSR= Expressed Sequence Tag-derived Simple Sequence Repeat

IPGRI=International Plant Genetic Resources Institute

MAS=Marker Assisted Selection=markerekre alapozott szelekció

PCR=Polymerase Chain Reaction=polimeráz láncreakció

QTL=Quantitative Trait Loci=kvantitatív tulajdonságokat meghatározó lókusz

RAPD=Randomly Amplified Polymorphic DNA=véletlen amplifikált polimorf DNS

RFLP=Restriction Fragment Lenght Polymorphism=restrikciós fragmentumhossz polimorfizmus

SCAR=Sequence Charecterized Amplified Region=ismert szekvenciájú amplifikált régió

$\mathrm{S}-\mathrm{SAP}=$ Sequence-Specific Amplified Polymorphism=szekvencia-specifikus amplifikált polimorfizmus

SSR=Simple Sequence Repeat=egyszerü szekvenciaismétlődés

UPOV=Union Internationale pour la Protection des Obtentions Végétales=Új Növényfajták Nemzetközi Fajtaoltalmi Szervezete 


\section{BEVEZETÉS}

A világon a banán és a citrusfélék után, a harmadik legnagyobb mennyiségben termesztett faj az alma. A világ almatermesztése azonban csak pár tucat fajtára alapul. Napjainkra a helyi és tájfajták üzemi termesztésben betöltött szerepe jelentéktelenné vált. A beszükült fajtahasználat ökológiai katasztrófa (klímaváltozás, új kórokozó fajok megjelenése stb.) esetén veszélyezteti a termesztés biztonságát, illetve jövedelmezőségét.

A régi almafajták a biodiverzitás szempontjából hatalmas értékkel bírnak. Megtalálhatók közöttük jó ellenállóképességü, kiváló beltartalmi értékü vagy speciális fogyasztói igényeket kielégítő fajták is. A változatos gyümölcsfogyasztás érdekében bővíteni kell a piaci kínálatot. Ezt nemcsak a régi fajták termesztésbe vonásával érhetjük el, hanem szülőfajtaként is felhasználhatjuk azokat új fajták előállításához.

Az elmúlt évtizedben számos országban megindult a génbankok diverzitásának felmérése. Ezzel jól jellemezhető egy adott térség korábbi fajtahasználatának genetikai sokszínüsége, más térségek fajtaösszetételével való azonossága vagy különbözősége. A munka során feltárják a tételek között előforduló téves elnevezésből adódó fajtaazonosságokat, félredokumentálásokat. A nemzeti és nemzetközi együttműködések és a közös adatbankok elősegítik a fajtaazonosság ellenőrzését, és lehetőséget nyújtanak az ismeretlen származású fajták keletkezési helyének meghatározására a leggyakoribb elterjedési területük felmérésével. Ehhez szükség van az azonos vizsgálati módszerekre, amelyek ECPGR általi kidolgozása folyamatban van.

Célszerü a fenológiai és a morfológiai leírások mellett a genotípus vizsgálata is. A fajták genetikai ujjlenyomatának meghatározása nemcsak a génbanki tételek azonosítása érdekében fontos, hanem a gyakorlatban, a faiskolai szaporítóanyagok fajtaazonosságának ellenőrzésére is felhasználhatjuk ezeket az adatokat. A fajtákra jellemző allélösszetétel ismerete lehetőséget nyújt a származásuk ellenőrzésére is. Jól kiválasztott genetikai markerekkel felmérhetjük a rezisztencia tulajdonságaikat, termékenyülési sajátosságaikat, növekedési és termésjellemzőiket is.

A génbankokban végzett diverzitásvizsgálatok lehetőséget adnak fajták azonosítására, és a pomológia vitatott kérdéseinek megválaszolására pl. a szinonim fajtanevek felülvizsgálatára, a fajtacsoportok elemzésére. A genetikai vizsgálatoknak szerepe van a filogenetikai kutatásokban is. Egy adott térségben keletkezett, illetve elterjedt fajtaválaszték elemzésével választ kaphatunk a pedigrére és esetleg - nagy mintaszám esetén - a származásra is. 
$\mathrm{Az}$ újabb szakirodalmakban nem találhatók meg a régi fajták leírásai. A régi szakirodalmak viszont nem adnak korszerü jellemzést, és hozzáférhetőségük is korlátozott. Ezért szükség van a fajták korszerü szempontok szerinti leírására. A nemesítőnek is érdeke, hogy ismerje a felhasználásra kerülő fajta tulajdonságait. Akár újbóli termesztésbe vonásról, akár nemesítésben való felhasználásról van szó, a régi fajták pomológiai és genetikai jellemzőinek ismerete kulcsfontosságú.

Napjainkban a régi almafajták iránti nosztalgiával találkozhatunk, divatos lett a régi fajták termesztése. Ez leginkább az ökológiai gazdálkodásban és a házikerti termesztésben jelenik meg, de az értékes fajták akár kisüzemi szinten is újra termesztésbe vonhatók. Ez nem feltétlenül jelent intenzív művelésmódot. A régi fajták többsége növekedési és terméshozási sajátosságaik miatt nem is alkalmas korszerü termesztésre. Ezzel szemben magas törzsü szórványgyümölcsös, hagyományos, illetve félintenzív ültetvényekben, erős vagy középerös alanyokon sikeresen termeszthetök.

Kutatásaink eredményeivel a génbanki vizsgálatokat és a fajták tulajdonságainak jobb megismerését kívánjuk elősegíteni, amely információk a kutatók és termesztők számára is hasznosak lehetnek. 


\section{IRODALMI ÁTTEKINTÉS}

\subsection{Régi almafajták szerepe a biodiverzitás megőrzésében}

Az alma a mérsékelt égöv legjelentősebb gyümölcsfaja, és bár bizonyos vélemények szerint tízezernél is több különböző almafajtát tartanak nyilván, napjaink almatermesztése csak pár tucat fajtára korlátozódik. Az ENSZ 1992-ben Rio de Janeiróban rendezett Környezet és Fejlődés Konferenciáján számos globálissá vált környezeti problémáról folytak tárgyalások. Ekkor született meg a Biológiai Sokféleség Egyezmény, amely a földi élet minden formáját védi, függetlenül attól, hogy az vadon élő, vagy az ember által termesztett növény, vagy tenyésztett állat. Alapelve, hogy az élővilág sokszínűségét meg kell őrizni, fenntartható módon kell használni, és a genetikai erőforrások hasznosításából (az élővilágból) származó hasznot igazságosan kell elosztani a fejlödő és a fejlett világ között. Az egyezmény a sokszínüség csökkenésének mértékét szeretné lassítani, ha megállítását már nem érheti el (Rodics 2008).

A tájfajta alatt az egyes tájakon a vidék éghajlatához jól alkalmazkodott, jellegzetes fajtát értünk. A helyi fajta egyes tájakon az önellátásra vagy közeli piacokra való értékesítésre termesztett fajta. Magyarországon sajátos, egyedi fajtaszerkezet jött létre az 1800-as évekre. A táji keretek és adottságok erős determináló hatással voltak a tájfajták kialakulására. Keletkezésük pontos módja az idő homályába vész, és már mint egy-egy tájegység jellemző fajtája váltak ismertté (Szani 2007, Holler 2007).

Surányi (2002) Gyümölcsöző sokféleség címü könyvében a tudományos, gazdasági és társadalmi-kulturális hatásuk szempontjából értékeli a régi fajták, helyi változatok előnyeit és hátrányait. Összességében megállapítja, hogy a történelmi és tájfajták használata növeli a biodiverzitást, hozzájárul a táj- és természetvédelem sikerességéhez, egészségesebb táplálékot biztosít, és az elmaradott térségek népessége számára pedig jobb megélhetést kínál.

Az idős gyümölcsösökben helyenként még fellelhető régi fajták jelentős genetikai és kulturális értéket képviselnek, melyek kiemelt fontosságúak a biodiverzitás megőrzése szempontjából. Az idős szórványgyümölcsösök állapota azonban nagyon leromlott, amióta a régi tulajdonosok felhagytak a müvelésükkel. A metszetlen, kaszálatlan ültetvények állapota évről évre egyre rosszabb (Tóth 2005a). A régi fajták in situ megőrzése csak nehezen megoldható a környezeti és antropogén tényezők miatt. Ex situ megőrzés lehetséges újonnan létesített tájgyümölcsösben, tankertekben, vagy növényi génbankokban. Egy 22 országban végzett svéd felmérés szerint a génbankokban fentartott fajták száma országonként 90 és 
2000 között változik, átlagban 750. Az endemikus fajták aránya 3-82\%, átlagban $33 \%$ (Nybom és Garkava-Gustavsson 2009).

A jövőben lehetséges változások pl. környezeti változás, új kórokozók és betegségek megjelenése vagy a fogyasztói szokások módosulása új fajták előállítását teszi szükségessé (Lespinasse et al. 2000). A nemesítő munkája a megfelelő szülők kiválasztásával kezdődik. A BCE Gyümölcstermő Növények Tanszéken végzett almanemesítési program (Tóth et al. 1994) keretében az egyik fő kutatási irány az új nemesítési génforrások felkutatása. Az elmúlt két évtizedben a Kárpát-medencében ismert régi genotípusok közül mindmáig közel 200 helyi fajtát gyüjtöttünk be tanszékünk génbanki ültetvényébe (G. Tóth 2005a, Tóth 2005a). Más európai almanemesítőkhöz hasonlóan (Tartarini et al. 2004, Kellerhals et al. 2012, Nybom et al. 2012) Magyarországon is vizsgáltuk a régi fajták betegségekkel szembeni ellenállóságát, s kiemeltünk közülük ellenálló és elfogadható minőségü fajtákat (G. Tóth 2005b, Tóth 2005c, Tóth et al. 2005a, 2005b, 2005c, 2013).

A génbankban található fajták egy része nemcsak a nemesítésben hasznosítható, hanem pl. a biogazdálkodásban is, ezért szükségessé vált a régi almafajták újraértékelése (Tóth 2005c, Papp et al. 2011, 2012, Szalay et al. 2012). A 150/2004. (X. 12.) FVM rendelet 5. számú melléklete (Kultúrtörténeti és genetikai szempontból kiemelkedő jelentőségü veszélyeztetett ritka szőlő- és gyümölcsfajták jegyzéke) 15 megőrzésre érdemes, régi almafajtát tartalmaz. A vidékfejlesztési miniszter gyümölcstájfajták állami elismeréséröl, valamint szaporítóanyagaik előállítási és forgalombahozatali feltételeiröl szóló 27/2012. (III. 24.) VM rendelete új lehetőségeket nyitott Magyarországon a régi fajták állami elismerésbe, illetve termesztésbe vonására, ezért a régi fajták pomológiai jellemzőinek ismerete kulcsfontosságúvá válik.

\subsection{Régi fajták pomológiai leírása, azonosítása}

A régi fajtákról fellelhető pomológiai leírások részletességükben és a leírás módszerében nem egységesek. Egyes szerzők nagyon részletes leírásokat adnak a magvak, rügyek, levelek tulajdonságaira vonatkozóan is, míg mások csak a gyümölcsök pomológiai jellemzését ismertetik. Több fajtaleíró kötetben is fellelhető, hogy egy fajtát több néven, vagy több fajtát azonos néven illetnek. Régi almafajták esetében gyakori, hogy egy fajtának több különböző neve is van (szinonímia). Almánál ritkább a homonímia, hogy azonos fajtanévvel több, morfológiailag jól elkülöníthető fajtát illetnek. Továbbá a régi gyümölcsfajták között is sok fajtacsoport ismert. A legtöbb pomológus az alapfajta jellemzése után csak felsorolja az egyes fajtaváltozatokat, s ezek pontos leírása vagy elkülönítése általában hiányzik vagy 
kevésbé informatív. Másfelől a hosszú ideje népi szaporítással terjesztett fajták esetében értékes rügymutációkat vagy magoncokat is kiválaszthattak, amelyek önálló fajtaként való elkülönítése indokolt lehet, ha az önálló genotípus morfológiai és genetikai vizsgálatokkal igazolható.

Különösen a génbanki gyüjtemények fajtaazonossága fontos, hiszen ha fajtakeveredés miatt egy fajtát a kívánatosnál több példányban tartunk fenn, akkor azzal értékes területet veszítünk, és a fenntartási költségek is növekednek. A génbanki állomány jellemzését elvégezhetjük taxonómiai, biogeográfiai, morfológiai és agronómiai szempontok szerint, vagy biokémiai, molekuláris jellemzők és markerek vizsgálatával. A régi almafajták esetében - az utóbbi pár évet leszámítva - elkülönülten alkalmazták a fajták azonosítására a genetikai, avagy a morfológiai vizsgálatokat, illetve pomológiai leírásokat. A morfológiai jellemzések mellett egyre terjed a DNS-szintü azonosítás, leggyakrabban mikroszatellitek (SSR=simple sequence repeats) alkalmazásával (Szalatnay et al. 2009, Santesteban et al. 2009, Gasi et al. 2010). Az UPOV a körtéhez hasonlóan az alma esetében is be akarja vezetni, hogy a DUS leírás mellett genetikai markerekkel is ellenőrzik a fajták megkülönböztethetőségét. Már részben kijelölték a használandó SSR markereket (UPOV 2003, 2010, 2011).

\subsection{Pomológiai leírások}

A pomológia a latin pomum = alma (átvitt értelemben gyümölcs) és a görög $\operatorname{logos}=\tan$, ismeret szavakból alakult ki. A XIV-XVI. században kezd elválni az egyéb kertészeti ismeretektől. A XVII-XIX. századra önálló alkalmazott tudomány lett. A pomológia tágabb értelemben a gyümölcstermő növényekkel, szükebb értelemben a fajtaismerettel foglalkozó tudományt jelenti. Sokféle értelmezése, ill. fordítása ismert: gyümölcsök tudománya, gyümölcsismerés, gyümölcsismeret, gyümölcsfajta-ismeret, gyümölcsfajta-rendszertan, gyümölcsészet (G. Tóth 2001).

\subsubsection{A pomológia korszakolása}

Tomcsányi (1998) a pomológia fejlődését 4 korszakra bontja. A pomográfia (leíró pomológia) korszakában legnagyobb jelentőséggel bírt Bereczki Máté munkássága, akinek saját fajtagyüjteményében végzett fajtamegkülönböztető leírásai eredményezték a négy kötetes Gyümölcstermesztési vázlatok (Bereczki 1877, 1882, 1884, 1887) címü müvet, amely a mai napig a régi fajták iránt érdeklődők elsőszámú forrásmunkája. Ehhez a korszakhoz sorolható a hazai kertészeti szakoktatás megalapozója, Entz Ferenc munkássága is. 
A pomometria (értékelő pomológia) korszakában a fajtaértékelés mérésen alapul, amikor is a fajtakutatók már nemcsak megismerni, hanem javítani is akarják a fajtákat. Ebben az időszakban indult a tudatos szelekció és a keresztezéses nemesítés. A leíró fajtaismeret és a fajtaértékelés összeolvadása tapasztalható, és a szöveges jellemzést kiegészíti, ill. alátámasztja a mérésen alapuló számokkal való jellemzés. A korszak legjelentősebb nemesítői Budai József, Magyar Gyula és Porpáczy Aladár, Brózik Sándor, Maliga Pál és Nyujtó Ferenc.

A pomológia harmadik korszaka a pomonómia (gazdasági pomológia), amely a morfológiai fajtajellemzésen túl a fajta gazdasági jellemzőit (pl. termőképesség) is vizsgálja, és ismerteti, ezáltal racionalizálja a fajtaválasztékot.

A negyedik korszak a fogyasztóorientált pomozófia (fajta- és piacformáló pomológia), amit Tomcsányi (1998) a jövő pomológiájának nevezett, de a tanulmány publikálása óta eltelt másfél évtizedben egyes elemek (pl. markeranalízissel és gyümölcsanalitikai vizsgálatokkal támogatott rezisztencianemesítés a BCE Gyümölcstermő Növények Tanszékén) már megvalósultak. A versenyhelyzet fokozódik, de nem szabad megfeledkeznünk a régi fajták termesztésben, nemesítésben és biodiverzitásban betöltött szerepéről sem.

\subsubsection{A pomológiai leírások típusai}

A pomológiai leírások a gyümölcstermő növények morfológiai és biológiai tulajdonságait ismertetik. A leírásokban szereplő tulajdonságokat Brózik (1974) három csoportba sorolta: vegetatív és reproduktív szervek tulajdonságai, továbbá biológiai tulajdonságok.

A vegetatív és reproduktív tulajdonságokat külső (pl. nagyság, alak) és belső (pl. gyümölcshús) morfológiai tulajdonságokra bonthatjuk. A vegetatív szervek tulajdonságai közé tartozik a gyümölcstermö növények növekedési erélye, a korona (bokor) habitusa, sürüsége, a termőrészek képződésének helye, a vessző és hajtás tulajdonságai. A reproduktív szervek tulajdonságai közé a gyümölcs (termés) méretére, alakjára, felszínére vonatkozó tulajdonságok (héjminőség, színeződés stb.), a kocsány- és csészemélyedés jellemzői, és a gyümölcshús tulajdonságai (pl. szín, íz, lédússág) tartoznak. Néhány pomológiai leírás a virág vagy virágzat tulajdonságait is ismerteti. A biológiai tulajdonságok közül leggyakrabban a virágzási és érési időt, a tárolhatóságot és a beltartalmat ismertetik a leírások (Brózik, 1974). 


\subsubsection{Pomológiai leíró módszerek}

A pomológiai leírásokat elkészíthetjük szubjektív és/vagy objektív adatok alapján (Brózik, 1974). A szubjektív leírás történhet teljesen szubjektív módon, vagy alapulhat bonitáláson vagy becslésen. Ebben az esetben általában vannak referenciafajták, amelyek alapján a tulajdonságok kifejeződési fokozatait felállítjuk. Az objektív leírások pontos pomometriai méréseken alapulnak. Ilyenkor megadhatjuk a pontos mért értéket (pl. a gyümölcsnek a tömegét), vagy a mért értékek alapján soroljuk be a fajtákat kifejeződési fokozatokba.

Objektív leírásra ad lehetőséget a mért adatok relatív értékben (pl. gyümölcsalakindex=gyümölcs magassága/átmérője) kifejezése, vagy egy standardhoz vagy egymáshoz viszonyított \%-ban (pl. hús-mag arány; $x$ fajta növekedési erélye $y \%$-kal gyengébb, mint $z$ fajtáé) megadása.

A legkorszerübb törekvések arra irányulnak, hogy a leírások a legjellemzőbb és a megkülönböztetésre alkalmas legeltérőbb alaktani és biológiai tulajdonságokat taratlmazzák. Elterjedt az objektív (pomometriai) és szubjektív (becslési és bonitálási) leíró módszerek együttes használata, amely gyors rögzíthetőséget biztosít, könnyen értelmezhető, de mégis tényszerü ismeretet nyújt.

\subsubsection{Számkulcsos pomológiai rendszerek}

A leírások egységes formátumú megjelenítéséhez jól felhasználhatók a számkulcsos leírások. Ezt már több külföldi és hazai pomológus is alkalmazta. Vercier (1948) három kötetes mủvében a legfontosabb pomológiai jellemzők (érési idő, tárolhatóság, gyümölcs alakja, csésze és kocsánymélyedés jellemzői, héj színe, gyümölcshús) számkulcsát ismerteti.

Brózik (1974) a korona és a gyümölcs morfológiai tulajdonságai mellett a biológiai, például a termőképességre, rezisztenciára és türőképességre vonatkozó sajátosságokat is számkulcsos rendszerbe illesztette. Rendkívül részletes leírás készíthető az általa kialakított kategóriák szerint, hiszen pl. a rügyek hajlása és alakja, pálha-, szirom- és csészelevelek hosszúsága, szélessége és alakja, magvak mérete és alakja stb. is szerepel az útmutatóban. Ez a részletes jellemzés viszont nem feltétlen szükséges a fajták megkülönböztetéséhez. Ezenkívül Brózik a levéllemez szélén belül pl. a klasszikus 4 (szimplán/ duplán csipkézett vagy fürészes) helyett 15 (az előző 4 változatai) kategóriát határozott meg, ami tovább bonyolítja a leírást.

Ma leggyakrabban az UPOV (Union Internationale pour la Protection des Obtentions Végétales, 2005) és a CPVO (Community Plant Variety Office, 2006) DUS-teszt elvégzéséhez ajánlott irányelveit használják, amelyek rövid leíró és számkulcsos megjelenítésben elegendő segédletet nyújtanak a fajták elkülönítéséhez. Előnyük, hogy 
nemzetközi szinten is alkalmazhatók, és a különböző kutatómühelyek eredményei jól összevethetők. A mai korszellemnek megfelelően az UPOV vizsgálati elvek célja a fajtákra vonatkozó szellemi tulajdonjog keletkeztetésének megalapozása, nem a fajták bemutatása. Ennek megfelelően egyáltalán nem törekszik teljeskörü leírások elkészítésére, hanem kizárólag a kielégítően fajta-szelektív, munka-, idő-, költség- hatékony fajtaleírásra. Az alma esetében az UPOV 14/8 számú irányelve 47-re csökkentette a vizsgálandó tulajdonságok számát, és csak ennek elégtelenségét tapasztalva emelték meg ismét 57-re. A gyümölcs szektorban 2006 óta törekszenek az UPOV és CPVO vizsgálati módszerek és a tulajdonság táblázatok harmonizálására, és időközben a CPVO is UPOV tag lett.

A növényfajták DUS-vizsgálata a megkülönböztethetőség, egyöntetüség és állandóság megállapítását szolgálja, de a fajta leírására is alkalmas, hiszen a legfontosabb megkülönböztető bélyegeket vizsgálja (UPOV, 2002). A DUS vizsgálatok végrehajtására az irányelvek tartalmazzák többek között a vizsgálat módját, a vizsgálandó növények számát, a megfigyelések helyét és időpontját, a szükséges mintaszámot, a tulajdonságtáblázatot és a csoportosító tulajdonságokat. A vizsgálandó tulajdonságok között megtalálhatók a fa habitusára, a vessző, hajtás, virág, gyümölcs morfológiájára és a fenológiához köthető tulajdonságokra vonatkozók is. A tulajdonságokat az UPOV a következők szerint csoportosítja: minőségi (kvalitatív) tulajdonságok (pl. fa típusa), mennyiségi (kvantitatív) tulajdonságok (pl. méret, molyhosság), minőségiként kezelt mennyiségi (pszeudokvalitatív) (pl. virágszín, gyümölcsfedőszín). Az UPOV 8 csoportosító tulajdonságot határoz meg, a hasonló fajták kiválasztásának elösegítésére, mint a fa típusa és habitusa, a gyümölcs alakja, a fedőszín kiterjedése, árnyalata és jellege, valamint a virágzás és érés időpontja. Ezen kívül a tulajdonság táblázatban kiemel csillaggal jelölve egyes jellemzőket, amelyeket nagyobb jelentőségünek tart.

Szalatnay (2005, 2006) és Szalatnay és Hunziker (2011) a gyümölcs génforrások leírására irányuló projekt (BEVOG) keretén belül a gyümölcs génforrások jellemzésére nagyrészt az ECPGR és UPOV leíró tulajdonságainak felhasználásával kidolgozott egy értékelő módszert, amely igen részletes, szöveges és számkulcsos jellemzésre ad lehetőséget.

\subsubsection{Almafajták rendszerezése a pomológiai múvekben}

A XVIII-XIX. században az almafajták nagy száma szükségessé tette azok valamilyen szempontok szerinti csoportosítását. Ezeket a rendszerezéseket leggyakrabban a gyümölcs alakja, színeződése és a gyümölcshús íze alapján készítették el. Legismertebbek Diel, Lucas és Hogg rendszerezései, de számos további pomológus készített hasonló rendszereket. 
Diel (1799) német pomológus rendszere az almafajtákat külső jellegeik alapján 7 főcsoportba sorolja, és ezen belül alcsoportokat tartalmaz különböző szempontok szerint (pl. alak, felület, magház alapján stb.). Ezek az alcsoportok nem egységesek, és nem találhatók meg minden föcsoportban. Mivel a XIX-XX. századi pomológiai müvekben ez a leggyakrabban alkalmazott, ismertetjük a föcsoportokat:

1. Bordás almák:
a. Valódi kálvil almák
b. Csörgő almák
c. Aranykák

2. Rózsaalmák

3. Rambúr almák

4. Renetek

a. Egyszínü renetek

b. Piros renetek

c. Szürke renetek

d. Aranyrenetek

5. Csíkos almák

6. Csúcsos almák

7. Pogácsa almák

Később Diel rendszerét a szintén német Lucas (1875b) finomította. A Diel által megadott fö csoportokon belül a gyümölcs héj színe (a: alapszínű, b: fedőszínü=mosott, c: csíkozott) és a csésze (a: nyitott, b: zárt) tulajdonságai alapján minden főcsoportban további alcsoportokat képezett, és Diel rendszerét kiegészítette további 3 föcsoporttal is (Galambkák, Rambúr-renetek, Borsdorfi-renetek).

Hogg (1851) nem tudta az angol fajtákra Diel rendszerét alkalmazni, ezért kialakított egy jellegében eltérő rendszert. A fő csoportokat az érési idők adják: nyári, őszi és téli fajták. Ezen belül következik az alak (a: kerek, kerekded vagy lapított, b: megnyúlt, kúpos vagy ovális) és a színeződés (a: alapszínü=gyenge színeződésü, b: csíkozott, c: mosott, d: parás) szerinti besorolás.

Warder (1867) amerikai pomológus az alak, íz és színeződés alapján alakította ki a csoportokat. Négy főcsoportot képezett: lapított, kúpos, kerek és megnyúlt. Ezeken belül az íz alapján megkülönbözteti az édes és a savas fajtákat, majd a szín szerint további 3 alcsoportot (mosott, csíkozott, parás) képez.

A szintén amerikai Thomas (1903) az almafajtákat Hogg rendszerére alapozva az érési idő szerint nyári, őszi és téli érésűekre bontotta. Ezeken belül megkülönböztette az édes, valamint a mérsékelten savas és savas, és ezen belül a piros fedőszínű vagy fedőszín nélküli fajtákat. Így összesen 12 csoportba sorolta a fajtákat.

Hasonló szempontok szerint alakította ki a csoportokat Beach et al. (1905), viszont a csoportok elnevezését észak-amerikai fajták adták: Fall Pippin, Northern Spy, Rhode Island 
Greening, Blue Pearmain, Winesap, Ralls Genet, Fameuse, Wealthy, Alexander, Duchess of Oldenburg és Orosz almák csoportokba.

Bunyard (1920) az angol almafajtákat a gyümölcs alakja, színeződése és íze alapján 7 csoportba sorolja, szintén sajátos nevezéktant alkalmazva: Lord Derby, Lanes, Peasgood, Golden Noble, Baumann, Blenheim és Cox’s, valamint Russet csoport.

Ezek a csoportosítások a hazai fajtákra nem, vagy csak részben adaptálhatók. Bereczki Máté (1877) „Az almák természetes családai” -nak ismertetésekor Lucas rendszerét vette alapul, és ezt alkalmazta a magyar fajták csoportba sorolásakor. Mivel kissé eltér a korábban bemutatott Diel-féle rendszertől, ezt is ismertetjük a Bereczki által megadott német és francia nevekkel együtt:

I. Ka1vi1 almák (Calvillen; calvilles)

II. Csörgő almák (Schlotteräpfel; cliquets)

III. Aranka almák (Gülderlinge; calvilles batârdes)

IV. Rózsa almák (Rosenäpfel; pommes roses)

V. Galambka almák (Taubenäpfel; pigeons)

VI. Fontos almák (Pfundäpfel; rambours)

VII. Fontos renetek (Rambourreinetten; canadas)

VIII. Egyszinü, vagy viasz-renetek (Wachsreinetten; reinettes blanches)

IX. Masánczki a1mák (Borsdorferreinetten; reinettesbatârdes)

$\mathrm{X}$. Piros renetek (Rothe Reinetten; reinettes rouges)

XI. Kormos vagy szürke renetek (Graue Reinetten; reinettes grises)

XII. Arany renetek (Gold-Reinetten; reinettes d' orées)

XIII. Csíkos almák (Streiflinge; pommes rayées)

XIV. Csúcsos almák (Spitzäpfel; pommes aigues)

XV. Pogácsa vagy tányér-almák (Plattäpfel; pommes plátes)

A Kárpát-medencében elterjedt fajták fenti rendszerekbe való besorolása nagyon nehézkes volt, s az új fajták számának gyarapodásával ez a probléma fokozódott. Ezért legújabban Tóth (2013) tett javaslatot egy modern pomológiai rendszerezésre. Ez a rendezési elv a Magyarország kultúrflórája megjelenés alatt álló 77. kötetében tanulmányozható.

\subsubsection{Régi magyar fajtákra vonatkozó forrásmunkák a virágzásfenológia és morfológia tükrében}

Régi magyar almafajták virágzási sajátosságaira vonatkozóan nagyon kevés szakirodalom áll rendelkezésre. A legtöbb használható és pontos adatot Brózik és Régius (1957) Termesztett gyümölcsfajtáink című müve ismerteti, amelyben az 1950-es évek nagyüzemi gyümölcstermesztésében megtalálható, de ma már régi, „,nosztalgia” fajtának számító fajtákra ('Húsvéti rozmaring', 'Batul', 'Londoni pepin', 'Nemes sóvári', 'Baumann renet', 'Nyári fontos', 'Simonffy piros', 'Sárga szépvirágú', 'Budai Domokos’) vonatkozó ismereteket kaphatunk. Néhány régi fajta ('Húsvéti rozmaring', 'Nyári fontos', 'Batul', 'Sárga 
szépvirágú', 'Simonffy pios', 'Budai Domokos’) esetében használhatók még Brózik és Nyéki (1975), valamint Soltész (1980, 1982, 1992, 2002) munkái is.

Morfológiai tulajdonságok tekintetében már jobb a helyzet, bár főleg a XIX. században keletkeztek ezek a pomológiai munkák. A legtöbb fajtát Bereczki (1877, 1882, 1884, 1887) négy kötetes Gyümölcsészeti vázlatok címü müve tartalmazza. Nagyon pontos és részletes leírást ad a fajtákról, bár helyenként a túlságosan részletes leírás, és a régi (bár nagyon szép) nyelvezet nehezíti a megértést. Szintén jól használható fajtaazonosításra Angyal Dezső (1926) Gyümölcsismeret című könyve, amely kevesebb fajtát ismertet, de nagyon szép ábrákat tartalmaz. Brózik és Régius (1957) Termesztett gyümölcsfajtáink címü müve a hagyományos, szavakkal leírás mellett a fajták számkulcsos jellemzését is megadja, és a fajták megismerését fényképek, rajzok segítik. Nagy-Tóth (1998) Régi erdélyi almák címü könyvében a Bolyai Tudományegyetem Növényélettani Intézetének, később az Erdélyi Múzeum-Egyesület tulajdonában lévő gyümölcsészeti kutatások szöveg és képanyagát dolgozta fel. Surányi (2002) Gyümölcsöző sokféleség című müvében szintén megtalálhatók a régi magyar almafajták leírásai.

A közös történelmi múltunkra tekintettel néhány szomszédos országban írt pomológiai munkában is megtalálható néhány magyar fajta leírása (Bordeianu et al. 1964, Stoll 1888). Néhány német és angol nyelvű pomológia (Hinterthür ca. 1890, Lucas és Oberdieck 1875, Oberdieck és Lucas 1860, Diel 1799-1816, Morgan és Richards 1993) szintén ismerteti a legjelentősebb magyar fajtákat, mert az 1800-as évek végén, az 1900-as évek elején divatos volt a szaporítóanyag csere.

Inkább csak kedvtelésből használhatjuk a faiskolai katalógusok (Kovács 1861, Molnár 1898a, 1898b) és kisebb pomológiai müvek (Girókúti 1863, Herszényi 1934) fajtaleírását, mert többnyire csak nagyon rövid jellemzést adnak, bár utóbbiak nagyon szép rajzokat is tartalmaznak.

Szakcikkek közül szintén kevés foglalkozik a régi fajtákkal. Elősorban a génbanki gyüjteményekben vagy szórványgyümölcsösökben végzett vizsgálatok eredményeit közlik (Komonyi 2010, Racskó et al. 2005, Szani 2007, Tóth és Szani 2004, Tóth 2005b). Tóth (2005b) öt régi magyar fajta ('Pónyik', 'Szemes alma', 'Sikulai', 'Szabadkai szercsika', 'Tordai piros kálvil') UPOV számkulcsos jellemzését készítette el, amelyek génforrásként javasolhatók a rezisztencianemesítési programokban. Ezek bővebb értékelését is ismerteti az akadémiai doktori értekezésében (Tóth 2005d). Szani (2011) doktori értekezésében történelmi alma- és körtefajtákat ismertet és jellemez a népi fajtaismeret és -használat tükrében. 


\subsection{Mikroszatellit (SSR) markerek fejlesztése és alkalmazási lehetőségei almánál}

\subsubsection{Mikroszatellit primerek fejlesztése}

A mikroszatellitek ( $\mathrm{SSR}=$ simple sequence repeat) 1-5 bp hosszúságú nagy polimorfizmust mutató DNS-szalkaszok, melyek a genomban szórtan helyezkednek el (Hajósné Novák, 1999). Weber és May (1989) a humán genomban, míg Morgante és Olivieri (1993) a növényi genomban található polimorf mikroszatellitek detektálásának PCR-technikán alapuló általános módszerét fejlesztették ki, amely során az SSR (Simple Sequence Repeat) régiót határoló, konzervált DNS-szakaszokhoz kötődő primerpárokat használnak. A PCR termék nagy elválasztóképességü gélen történő futtatásával detektálni lehet az ismétlődő egységek számának különbségét. A PCR módszer széles körü elterjedését a hőstabil DNS-polimeráz (TAQ polimeráz) alkalmazása, valamint az automatizált fütőblokk (PCR készülék, thermocycler) kialakítása tette lehetővé.

Az elmúlt 10-15 évben leggyakrabban a mikroszatellit markereket választották fajtaazonosság meghatározására és a diverzitás vizsgálatokhoz, mert gyakran fordulnak elő a növényi genomban, nagy polimorfizmus jellemzi őket, használatuk egyszerü és automatizálásra alkalmasak. Kodominánsak, Mendeli öröklődésủek, ezért származás vizsgálatra is alkalmasak (Varshney et al. 2005). A fenti tulajdonságaik, a PCR-technikán alapuló mérés kis DNS-szükséglete, és az adatok laboratóriumok közti könnyü kicserélhetősége, a viszonylag olcsó, egyszerü, gyors használatuk, az év bármely időszakában, már fiatal növényeken is alkalmazhatóságuk miatt gyorsan elterjedtek főleg a fajtaazonosítás és diverzitás vizsgálatok céljára. Kiválóan alkalmazhatók az új egyedek genotipizálására. Ráadásul a lókuszonként kettőnél több allél megjelenése esetén a triploid és tetrapolid egyedek is kiemelhetők. Az SSR-en alapuló kapcsoltsági térképek segítséget nyújtanak a varasodás-, lisztharmat- és tüzelhalás-rezisztenciáért, valamint a morfológiai és fiziológiai tulajdonságokért felelős főgének és QTL-ek azonosításában és pozícionálásában.

Napjainkban az alma esetében már több mint 300 mikroszatellit marker áll a kutatók rendelkezésére. Guilford et al. (1997) készítették az első alma SSR markereket a 'Royal Gala’ fajtából létrehozott genomi könyvtár segítségével, és az egylókuszos SSR markereket sikeresen alkalmaztaák 21 fajta azonosítására.

Hokanson et al. (1998) 8 új GD-elnevezésủ SSR markert állítottak elö, amellyel 66 fajtát teszteltek. Az eredmények alapján készített fenogram megegyezett a földrajzi származással, és az ismert pedigrével, ezért a fajtavizsgálatokhoz javasolják az SSR markerek használatát.

Gianfranceschi et al. (1998) 16 új alma SSR markert (CH-sorozat) fejlesztettek ki, amelyeket 19 almafajtán és a Malus floribunda 821-en is teszteltek. Két nagy polimorfizmust 
mutató marker segítségével két fajta (a 'Red Delicious' és szomatikus mutánsa, a 'Starking') kivételével sikeresen meg tudták különböztetni egymástól a fajtákat.

Liebhard et al. (2002) 140 új alma mikroszatellit primert (CH-sorozat) fejlesztettek ki, és alkalmazhatóságukat tesztelték 8 fajtán. Vizsgálatba vontak korábban kifejlesztett primereket is, úgy, mint az MS-, NZ- és COL-SSR markerek (Guilford et al. 1997, Hemmat et al. 1997). Ebböl 115 markernek a helyzetét feltérképezték a 'Fiesta' × 'Discovery' kapcsoltsági térképen, és a 17 almakromoszámának megfelelően 17 kapcsoltsági csoportot azonosítottak. Tizenöt SSR marker alkalmazhatóságát tesztelték 43 Rosaceae fajnál. Megállapították, hogy a Maloideae alcsaládba tartozó fajoknál mindegyik jól alkalmazható, míg az Prunoideae fajainál csak egy marker adott használható eredményt.

Silfverberg-Dilworth et al. (2006) 148 új SSR (Hi-sorozat) markert fejlesztettek ki, jellemezték és helyezték el a 'Fiesta' × 'Discovery' alma referencia kapcsoltsági térképen. Azt tapasztalták, hogy a dinukleotid ismétlődő szekvenciákból álló markerek sokkal informatívabbak voltak, mint a trinukleotid ismétlődéseket tartalmazók. Továbbá tesztelték néhány körtére és Sorbus torminalis-ra kifejlesztett SSR marker alkalmazhatóságát alma esetében.

Yao et al. (2010) 147 új EST-SSR (Expressed Sequence Tag-derived Simple Sequence Repeat) markert fejlesztettek ki (MES-sorozat), melyek közül 18-cal Malus fajok és fajták genetikai diverzitását tesztelték. Vizsgálták továbbá a Malus markerek Pyrus fajokon való alkalmazhatóságát is. Az EST-SSR-ek elméletben könnyebben átvihetők, azaz alkalmazhatók rokon fajoknál, mert a genom konzerváltabb kódoló régióiban helyezkednek el. Valójában éppen azért, mert az átíró régióban helyezkednek el, sokkal konzerváltabbak, és kevésbé polimorfak, mint a genomi SSR markerek. Hasonló eredményeket kapott Hu et al. (2011) uborkafajták vizsgálatakor. Ezzel szemben Zhang et al. (2012) vizsgálataiban az ESTSSR-ek nagyobb polimorfizmust mutattak, mint a genomi SSR-ek.

\subsubsection{Mikroszatellit markerek alkalmazási lehetőségei}

\subsubsection{A génbanki gyüjtemények genetikai diverzitásának felmérésétől a fajtaazonosításig}

Hokanson et al. (1998) a GD-sorozatba tartozó 8 SSR markerrel végezték a génbanki állomány diverzitásának felmérését, amely vizsgálatban 66 almafajtát azonosítottak. A markeranalízis során a rügymutációval keletkezett fajtákat nem tudták elkülöníteni egymástól, ill. az alapfajtától, továbbá a genevai gyüjtemény két fajtájának fajtazonossága is megkérdőjeleződött. A klaszteranalízis nem minden esetben adott meggyőző eredményt a származásra vonatkozóan. 
Kenis et al. (2001) almafajták és hibridek azonosítására és a származás ellenőrzésére használták a Guilford et al. (1997) és Gianfranceschi et al. (1998) által fejlesztett SSR markereket.

Laurens et al. (2004) francia génbankok morfológiai és agronómiai adatainak összegzésekor számos szinonim fajtát és fajtakeveredést tapasztalt. A tévedések kizárása érdekében molekuláris markereket alkalmaztak 142 francia helyi fajta vizsgálatba vonásával. Hét pár azonos genotípusú fajtát találtak, amelyeket szinonim fajtaként kell kezelni. Nagyfokú genetikai diverzitást mértek, csak néhány kisebb fajtacsoportot tudtak klaszterbe sorolni. A molekuláris adatok alapján elvégzett klaszteranalízis nem sorolta egy csoportba a francia fajtáknál használt három fenotípus szerinti fajtacsoport ('Reinette', 'Calville', 'CourtPendu’) tagjait. A földrajzi származás szintén nem befolyásolta a csoportosítást.

Galli et al. (2005) 66 világfajtát, köztük számos rügymutációval keletkezett fajtát vizsgáltak 6 SSR markerrel. Néhány fajta esetében a szülőfajtákat is azonosítani tudták, ráadásul pár triploid fajtánál meg tudták határozni, hogy melyik fajta volt az anyapartner, és melyik a pollenadó. A rügymutációval keletkezett fajtákat nem tudták elválasztani az alapfajtától.

Guarino et al. (2006) olasz fajtagyüjteményben 48 olasz és 8 világfajta bevonásával, 9 SSR marker alkalmazásával végzett vizsgálatai során felmérte a gyüjtemény genetikai diverzitását, elvégezte a fajtaazonosítást és 27 genotípust azonosított mint szinonimát. Néhány esetben azonban az azonos nevü fajtáknál (homonímák) eltérő SSR profilt találtak, de erre az eltérésre az előzetes fenotípusos jellemzések nem hívták fel a figyelmet.

Song et al. (2006) ipari (ivólé és cider) és friss étkezési fajtákat vizsgáltak 12 SSR markerrel. A klaszteranalízis 4 csoportot eredményezett: az igen savas ipari fajta, a nagy tannintartalmú cider fajták, a kínai vad fajoktól származó kettős hasznosítású (cider és frisspiaci) fajták, és a többi ipari (ivólé) és frisspiaci fajta.

Pereira-Lorenzo et al. (2007) 114 helyi (Spanyolország észak-nyugati részéről származó) és 26 nemzetközi fajtán vizsgálták SSR markerekkel a genetikai diverzitást, továbbá céljuk volt a duplikációk és tévedések kiszürése. Néhány duplikációt és 6 szinonima csoportot azonosítottak, melyeket csupán morfológia alapján nehéz lett volna kiszürni a nagyszámú gyüjteményben. Nagyfokú genetikai diverzitást tapasztaltak a helyi fajták között. Jelentős számú triploid fajtát (28 \%) és egyedi vagy ritka allélt ( $8 \%$ ) találtak.

Későbbi munkájukban (Pereira-Lorenzo et al. 2008) ezeket a fajtákat összevetik kanáriszigeteki helyi fajtákkal, melyeket a feltételezések szerint a XV. században vittek a szigetekre. A vizsgálatok jelentős eltéréseket mutattak a spanyol és a nemzetközi fajták 
között. A galliciai és a la palmai fajták között kisebb genetikai távolságot találtak, ami a közös származásra enged következtetni.

Wichmann et al. $(2007,2010)$ 40, többségében régi magyar almafajta genetikai ujjlenyomatát készítették el az általuk választott hat, ill. az Európai Alma Munkacsoport (European Apple Workshop, Laurens et al. 2004) által kijelölt nyolc SSR marker alapján. Azt tapasztalták, hogy az általuk választott primerek a legtöbb esetben nagyobb heterozigótasági értéket mutattak, tehát jobb elkülönítőképességgel rendelkeznek. Javaslatot tettek az ECPGR által kijelölt markerkörben megtalálható többlókuszos markerek kicserélésére.

Rouston et al. (2009) Arizóna, Utah és Új Mexikó államokban régi farmokon 280 alma genotípust gyüjtöttek be morfológiai és SSR markerekkel végzett fajtaazonosítás és diverzitás vizsgálatok céljára. A minták $43 \%$-át (120 fajta) sikerült azonosítaniuk, de 160 minta (110 egyedi ujjlenyomatot hordozó genotípus) esetében nem találtak azonosságot a kontroll fajtákkal. Mivel a kontroll fajtákat faiskolák és a nemzeti fajtagyüjtemény adták, így ezek a genotípusok értékes egyedi fajták, helyi magoncok, a faiskolai frogalomból kimaradt, vagy más területekről százmazó fajták lehetnek, amelyek ezekre a farmokra a 19. század végén, a 20. század elején kerülhettek. Az „egyedi fajta” kifejezést azokra a fajtákra alkalmazták, amelyek mikroszatellit ujjlenyomata nem mutatott egyezést a rendelkezésre álló referencia fajtákkal, és a többi kérdéses fajtával sem. A minták földrajzi elkülönülése jelezte, hogy különböző forrásból származtak az almafák. Már a XVII. század elején spanyol lelkipásztorok, kutatók és telepesek behurcolták az almafajtákat Új-Mexikóba. A XVIIXVIII. században magonc almafákból ültetvényeket hoztak létre cider készítési és takarmányozási célokra. Amely egyedek kiváló gyümölcsminőséggel rendelkeztek, elnevezték őket, megőrizték és tovább szaporították.

Patzak et al. (2009) 102 régi és helyi cseh fajta bevonásával bizonyították a génbanki állomány nagy genetikai variabilitását, viszont nagyobb hasonlósági csoportokat nem kaptak. Későbbi vizsgálatokban (Patzak et al. 2012) a cseh fajták mellett számos nemzetközi fajtát (összesen 130) is elemeztek. Ekkor már három nagy csoportba ('Cox’s Orange Pippin', 'McIntosh’ és ‘Golden Delicious’ leszármazottai) sorolódtak a fajták a klaszteranalízis során. Megállapították, hogy a klaszterbe sorolás nagymértékben függ a fajták pedigréjétől és a származásától. Az alkalmazott 10 SSR markerrel nem sikerült az alapfajtától a rügymutációval keletkezett fajtákat elkülöníteni. Azt tapasztalták, hogy a 10 marker hatékonyabb diverzitás vizsgálatot tett lehetővé, mint a korábban alkalmazott kevesebb számú marker.

Bassil et al. (2009) az Azori-szigetcsoportba (Portugália) tartozó Terceira-sziget almaés körtefajtáit hasonlították össze portugál és amerikai fajtákkal 9 SSR marker segítségével. 
Főként olyan helyi fajtákat gyüjtöttek be különböző településekről, amelyek hasonló morfológiai bélyegekkel rendelkeznek, de mégis eltérő az elnevezésük (szinonimák), vagy az eltérő a morfológiájuk ellenére, mégis azonos néven ismertek (homonimák). Az SSR vizsgálatokat morfológiai és fenológiai megfigyelésekkel egészítették ki. Az amerikai fajták között nagyobb diverzitást találtak, mint a terceirai fajták között, de a megfigyelt heterozigótaság mindkét csoportban nagyobb volt, mint a várható érték. A klaszteranalízis az alma- és körtefajtákat két külön csoportba sorolta, és a tercierai almafajtákat a „maçā” és a „reinette” csoportra bontotta. A 17 őshonos fajta között hét egyedi genotípust és négy szinoním elnevezést vagy lehetséges fajtacsoportot, továbbá 1 homoním elnevezésű fajtapárt találtak. Az amerikai és a terceirai fajták között nem találtak rokonságot.

Van Treuren et al. (2010) 695 holland génbanki fajta diverzitását vizsgálta 16 SSR markerrel, melynek során 475 különbözö genotípust tudtak elkülöníteni. Számos esetben a mikroszatellit és a törzskönyvi, illetve morfológiai adatok nem mutattak egyezést, azaz a fajtaazonosság megkérdőjeleződött. Számos duplikációt mutattak ki a gyüjteményben, továbbá 45 tévesen nyilvántartott genotípust sikerült meghatározniuk. A duplikációk kizárása után a gyűjtemény $40 \%$-a a törzskönyvi adatokkal megegyezett, míg $60 \%$-a nem mutatott egyezést. Ez felhívja a figyelmet arra, hogy a génbanki gyüjteményekben még gondosabb leltárt kell vezetni, hiszen számos kutató az innen szerzett minták, ill. adatok alapján végzi a kutatást, és a fajtakeveredés téves eredmények közléséhez vezethet. További céljuk volt a vizsgálatba vont SSR markerek fajtaazonosításban való használhatóságának értékelése. A használt markerek közül három az ECPGR által fajtaazonosításra kijelölt markerkörben is megtalálható. Multiplex PCR tesztelésekor a CH02c02b/CH05e04 és CH02d08/U50187-SSR primerek együttes kiértékelése nehéz volt.

Gasi et al. (2010) 24 bosznia-hercegovinai és 15 nemzetközi fajta bevonásával, 23 morfológiai és 10 SSR marker használatával mérték fel a génbanki gyüjtemény genetikai variabilitását. A rügymutációval keletkezett fajták kivételével valamennyi fajtát sikerült elkülöníteniük SSR markerekkel. A molekuláris adatok alapján a nemzetközi fajták jól elkülönültek a hagyományos fajtáktól, viszont a morfológiai adatok alapján ez nem jelenthető ki egyértelmủen. A nemesítés szempontjából azonban mindkét módszer egyformán fontos, föként azért, mert nem találtak összefüggést a kétféle adatsor között.

Farrokhi et al. (2011) iráni fajták és tájfajták genetikai variabilitását mérték fel 16 SSR lókuszon. Más országok kutatói által korábban végzett génbanki diverzitásvizsgálatok eredményeihez képest meglepően kis allélszámot (2-5 allél, átlagban 2,8) tapasztaltak, amit az elválasztási technikával magyaráztak. 
Sikorskaite et al. (2012) régi litván és nemzetközi almafajták genetikai diverzitását vizsgálták 11, az ECPGR által első körben javasolt SSR markerrel (ld. 2.4.2.8. fejezet). Két fajta kivételével az összes fajtát meg tudták különböztetni egymástól. A litván fajták között 38 egyedi allélt találtak, ami a régi fajták nagy genetikai variabilitását bizonyítja.

Storti et al. (2012) három fajta ('Antonovka', 'Laxton's Superb' és 'Worcester Pearmain’) mintáit gyüjtötte be Európa több génbanki gyüjteményéből, és 14 SSR marker használhatóságát vizsgálta a fajtaazonosítás és az adatok összevethetősége szempontjából. Az 'Antonovka' minták két különböző genotípust mutattak, ami nem meglepő, hiszen az Oroszországból származó fajta számos változattal rendelkezik. A 'Worcester Pearmain' esetében szintén két eltérő genotípust kaptak, és különböző fajták pedigréjéből (amelyekben a ‘Worcester Pearmain' szerepelt) következtetve az angliai minta bizonyult fajtaazonosnak. Az eredmények ismét rámutatnak a génbanki gyüjtemények dokumentálási hibáira.

\subsubsection{Rügymutációval létrejött fajták azonosításának nehézségei}

A mutáció a sejt genetikai anyagában bekövetkezett és fennmaradt változás (Patthy 1999). Mutáció bekövetkezhet a testi vagy az ivarsejtekben. A szomatikus mutációk a soksejtü szervezetek testi sejtjeiben keletkeznek és az osztódással adódnak tovább. A fejlődés korai szakaszában fellépő mutáció a szervezet valamennyi sejtjére kiterjedhet az osztódás és a növekedés folyamán. A szomatikus mutációk bekövetkezhetnek a rügy-, illetve virágképződés folyamatába is (rügymutáció). A mutációk egy része a fenotípusban is megjelenik, míg a többi változásra csak a DNS vizsgálata deríthet fényt. A gyümölcstermö növényeknél leggyakrabban a morfológiai és a színmutációk fordulnak elő, amelyek alak, méret (pl. kompakt növekedés) vagy színváltozást eredményeznek (Velich 2001). A mutáció keletkezési helye szerint megkülönböztetünk periklinális és szektoriális mutációt. A periklinális mutáció gyakran csak egyetlen (L-1) sejtréteget érint a merisztéma zónában, de érintheti az L-2 sejtréteget is. Vegetatív szaporítással örökíthető, de instabil, és gyakori a visszamutálás. A szektoriális vagy meriklinális mutáció a hajtáscsúcs iniciálisban (szektorban) bekövetkező mutáció, amelynek öröklődése bizonytalan (Brown és Maloney 2003).

A mutáció útján keletkezett változatokat a keresztezéses nemesítésben szülőfajtaként felhasználhatjuk, de ez csak azon mutációknál lehet sikeres, amelyeknél a mutáció az L-2 réteget is érintette. Számos nemesítő (Kelsey és Brown 1992, Ogjanov et al. 1999, Blazek és Krelinová 2011) ezért tudta sikerrel alkalmazni az oszlopos habitusú ‘Wijcik McIntosh' fajtát szülőfajtaként. Ezzel szemben a ‘McIntosh’ sugárkezeléssel indukált mutációja, amelynél a 
mutáció csak egy sejtréteget érintett a csúcsmerisztémában, a 'Golden Delicious'-szel kombinálva egyetlen kompakt hibridet sem eredményezett, mert ez a változat valójában egy kiméra (Lapins 1969, cit. Janick et al. 1996).

Az úgynevezett „óriás” mutáció esetében a ploidszint változás, leggyakrabban a kromoszóma-kettőződés figyelhető meg: diploidból tetraploid vagy triploidból hexaploid lesz. Ezek a mutánsok óriási, néha kétszer akkora gyümölcsöket nevelnek, mint a diploid változatuk, és a gyümölcs alakja gyakran lapított, és szabálytalan. Ezek a mutánsok gyakran periklinális mutációval keletkeznek (Janick et al. 1996).

A szomatikus mutációval (leggyakrabban rügymutáció) keletkezett fajták nagyon gyakoriak az alma esetében. Pl. a 'Delicious', 'Elstar', 'Gala', 'Jonagold' fajták számos rügymutánsa van jelen a termesztésben, amelyek leginkább a gyümölcs színeződésében, vagy a héj parásodásának mértékében különböznek egymástól. Ezek azonos SSR ujjlenyomatot mutathatnak annak ellenére, hogy néhány morfológiai tulajdonságban (pl. gyümölcs színeződése) egyértelmü különbséget mutatnak (Bassil 2009).

A közeli rokonság vizsgálatára alkalmasak az SSR markerek, viszont a rügymutációval keletkezett fajták elkülönítésére eddig sikertelenül alkalmazták azokat (Gianfranceschi et al. 1998, Hokanson et al. 1998, Galli et al. 2005, Gasi et al. 2010, Patzak et al. 2012). A rügymutációval keletkezett fajtáknak gyakran azonos az allélösszetételük, hiszen a szomatikus mutánsok csak egy vagy néhány kisebb régióban különböznek, ezért kicsi az esélye, hogy éppen egy olyan SSR markert találunk, amely lehetővé teszi a szomatikus mutációval létrejött fajták elkülönítését. A rügymutációval keletkezett fajták elválasztásához nagyobb polimorfizmussal rendelkező markerek szükségesek, mint pl. AFLP, ISSR, retrotranszpozonok, amelyek várhatóan jobb eredményt adnak, mint az SSR (Tignon et al. 2001, Venturi et al. 2006).

Az SSR markerek polimorfizmusa nagy, de a genomban csak viszonylag kis mennyiségben fordulnak elő, és gyakran a nem kódoló régióban. Ezért kicsi az esélye, hogy a mutáns fajták esetében a pontmutáció éppen a vizsgált régióban következett be. Az AFLP, ISSR és transzpozonon alapuló markerek nagyobb felbontóképességgel rendelkeznek, nagyobb számban hasítják a DNS-t. A rügymutációk kialakulásának genetikai háttere még nem teljesen tisztázott, de valószínüleg retrotranszpozonok állhatnak a mutációk kialakulásának hátterében. A retrotranszpozonok szekvenciái mind fajon belül, mind a fajok között rendkívül nagy változatosságot mutatnak. Ezek az egyedi, de mégis nagy változatosságot mutató szekvenciák, jó alapul szolgálhatnak, speciális marker rendszerek kidolgozására, melyek alkalmasak lehetnek az egy fajtakörbe tartozó fajták (rügymutánsok) azonosítására és megkülönböztetésére. 
Venturi et al. (2006) S-SAP (sequence-specific amplified polymorphism) technikával azonosítottak retrotranszpozon régiókat, amelyek alapján sikeresen megkülönböztették a 'Gala' és 'Braeburn' rügymutációval keletkezett fajtáit. Galli et al. (2008) szintén S-SAP retrotranszpozonokkal csak a 'Jonathan' alapfajtát tudta a többi 'Jonathan' fajtától elkülöníteni, de a fajták között nem tudtak különbséget tenni. Zhao et al. (2010) szintén SSAP markerekkel különböztette meg a 'Fuji’ fajtákat egymástól és az alapfajtától.

\subsubsection{Rokonsági vizsgálatok}

Az újabb fajták többsége irányított keresztezésből származik, így ismert a pedigréjük, viszont sok termesztésben lévő fajta szabadmegporzású vagy véletlen magoncállományból került kiemelésre. A fajták származásának ismerete különösen a nemesítők számára fontos, hiszen ha ismerjük a fajta pedigréjét, tudjuk, milyen tulajdonságokat örökölhetett, illetve örökíthet a keresztezéses nemesítés során.

Kitahara et al. (2005) S-allél vizsgálatok során számos ismeretlen és bizonytalan származású japán fajtát találtak, amelyek szülőfajtájának pontos meghatározását SSR markerekkel végezték el. Cabe et al. (2005) 11 SSR marker segítségével elvetették a 'Honeycrisp' fajta feltételezett származását, és javaslatot tettek a valódi szülőkre vonatkozóan. Egy másik nagy jelentőségű minesotai fajta, a 'Haralson’ származását viszont kétséget kizáróan igazolni tudták.

Reim et al. (2009) pillnitzi almafajták (Pi- és Re-sorozat) szülőfajtáit ellenőrizték. A fajták nagy részénél helyes volt a dokumentált származás, viszont néhány esetben ('Realka', 'Reanda', 'Rebecka', 'Reglindis') a nyilvántartott anya vagy a pollenadó fajta nem volt helyes. Egy fajtánál ('Rebella') pedig egyik feltételezett szülő sem szerepel a vizsgált fajta pedigréjében, valószínűleg az oltóvesszők elcserélése okozza a tévedést.

Király et al. (2009) magyar nemesítésből származó hibridek és fajták nemesítő által leîrt szülőfajtáinak egyezését vizsgálták. A legtöbb hibrid és a Kov-fajták származását bizonyították, de az MR-11 és A-75 hibridek pollenadó szűlője nem egyezett a nemesítő által közöltekkel. Tóth et al. (2012a) új hazai nemesítésü almafajták ('Artemisz', 'Cordelia', 'Hesztia’ és 'Rosmerta') származását igazolta 12 SSR marker használatával.

Evans et al. (2011) a HiDRAS program keretében hat európai ország 307 ismert származású fajtájának és hibridjének pedigréjét ellenőrizték 80 SSR marker használatával. 125 fajtánál mindkét szülőt azonosítani tudták. 23 fajtánál csak az anyafajtát tudták meghatározni az ismeretlen vagy helytelenül dokumentált származás miatt, további 26 tételnél vagy az anya- vagy az apafajtát sikerült azonosítani a minta hiánya miatt, valamint 12 
tétel esetében szintén csak az egyik szülőt tudták meghatározni, mert a másik szülő nem mutatott rokoni viszonyt a vizsgált fajtával. Három fajta, ill. hibrid ('Dayton', 'Liberty' és X2773) származását tévesnek találták, és nem is sikerült azt meghatározni. A vizsgált fajták között 8 triploidot találtak, ebből 7-nek meg tudták határozni a pontos származását. A nagyszámú vizsgált fajta között arányaiban jóval kevesebb triploidot találtak, mint más kutatók, ezért javasolják, hogy vegyük figyelembe az almagenom 17 kromószómájának kialakulásakor végbement kromoszóma duplikációból vagy homológ kromoszómákról származó esetleges többletallélokat.

Moriya et al. (2011) 45 almafajtát először 42, majd szükítve a legnagyobb polimorfizmust mutatókra, 14 SSR marker használatával vizsgáltak. A rügymutációval keletkezett fajtákat nekik sem sikerült elkülöníteni az alapfajtától. Vizsgálták a fajták nyilvántartott szülőfajtáinak azonosságát is, és néhány esetben eltérést találtak a leírtakhoz képest.

Baric et al. (2012) a Dél-Tirolban nagy jelentőségü, szabadalomra bejegyzett Meran fajta szülőfajtáit vizsgálta 14 SSR markerrel. Megállapították, hogy a 'Golden Delicious' × 'Morgenduft' kombinációban a 'Morgenduft' biztosan nem lehet a pollenadó. Az előállítás évében (1975) legnagyobb arányban termesztett fajtákat vonták be a vizsgálatokba, melyek közül a 'Jonathan' bizonyult a Meran lehetséges pollenadó szülőjének. Ez mind a molekuláris, mind az előzetes morfológiai vizsgálat alapján kijelenthető.

\subsubsection{Filogenetikai vizsgálatok}

Hokanson et al. (2001) 142 vad Malus genotípust vizsgált a korábban általuk leírt nyolc primerrel (Hokanson et al. 1998). Meghatározták a gyüjtemény genetikai variabilitását, és próbáltak következtetni a rokonsági viszonyaikra, és összefüggést keresni a molekuláris adatok és a fajok földrajzi származása között, de a klaszteranalízis nem támasztotta alá a származásra vonatkozó ismereteket.

Garghani et al. (2009) Irán termőhelyeinek szerepét vizsgálták a termesztett almafajták kialakulásában, ezért a világ különböző részéröl begyüjtött, 159 vad és termesztett almafajt, fajtát (köztük régi iráni fajtákat is), ill. alanyfajtákat elemeztek SSR markerekkel. A klaszteranalízis alapján az iráni fajták közelebbi rokonságban állnak a közép-ázsiai (kazahsztáni) Malus sieversiihez, és a törökországi és oroszországi Malus orientalishoz, mint más vad Malus fajokhoz. A világ más részéről begyüjtött régi fajták is közelebbi rokonságot mutatnak a Malus sieversiihez, Malus orientalishoz, és az iráni fajtákhoz, mint más vad Malus fajokhoz. Ez alapján feltételezik, hogy az iráni almafajták a termesztett régi fajták és a 
vad fajok között helyezkednek el, így Iránnak jelentős szerepe lehetett az alma domesztikációjában és a fajok Közép-Ázsiából a nyugati országokba szállításában. Forte et al. (2002) szintén arra a következtetésre jutottak morfológiai és RAPD-analízis és ITS1, 5.8S rRNA, ITS2 és a matK gén kódoló régiójának szekvenciaadatai alapján, hogy a Malus sieversii áll a legközelebbi rokonságban a termesztett fajtákkal. Másodlagos szerepe pedig a Malus sylvestris fajnak lehetett. Ezt a megállapítást a 'Nemes sóvári' esetében $S$-genotípus vizsgálatokkal és az $S_{1}$-allél parciális szekvenálásával Halász et al. (2011) is megerősítették.

Zhang et al. (2012) 17 világfajta és 12 Kínában fellelhető Malus vad faj bevonásával végezték a genetikai variabilitás jellemzését, és a Malus sieversii vad faj és a termesztett fajták közötti rokonsági viszonyok elemzését. A klaszteranalízis során két nagy csoportot kaptak. Az egyik csoportba 16 fajta és a Malus sieversii került, míg a másik csoportba a többi vizsgált vad faj és egy orosz fajta, mely vélhetően közeli rokonságban áll ezekkel a vad fajokkal. A termesztett fajták Malus sieversiivel való rokonságát már korábbi irodalmakban is fellelhetjük, amelyek feltételezik, hogy a Malus sieversii a Selyemúton került be Európába, és fontos szerepe volt a termesztett alma kialakulásában (Juniper et al. 1996, Harris et al. 2002).

Velasco et al. (2010) molekuláris vizsgálatai alátámasztották, hogy a Malus × domestica közelebbi rokoni kapcsolatban áll a M. sieversiivel, mint a Malus sylvestris, M. baccata, M. micromalus és $M$. prunifolia fajokkal. Megerősítették a Malus sieversii genetikai hasonlóságát a $M$. orientalishoz és a $M . \times$ asiaticához, továbbá alátámasztották a $M . \times$ domestica génállományának a $M$. sieversiiéből való kialakulását.

Urbanovich és Kazlovskaya (2009) 108 fehéroroszországi régi és modern fajtát, továbbá vad fajt vizsgáltak 20 SSR marker használatával. Sok ritka allélt csak a vad fajokban, vagy azok leszármazottaiban találtak meg. A klaszteranalízis által kialakított csoportok összefüggést mutattak a fajták pedigréjével és földrajzi származásával, és a Malus fajok külön csoportot alkottak.

Potts et al. (2012) az Illinoisi Egyetem génbanki gyüjteményében található Malus fajok, fajták és hibridek (összesen 164 egyed) diverzitását mérték fel a 17 kapcsoltsági csoportnak megfelelő 17 SSR markerrel. A rügymutációval keletkezett fajták kivételével minden fajt, ill. fajtát meg tudtak különböztetni egymástól. A gyüjteményben 39\%-ban találtak ritka allélokat, ami <5\% alatti gyakoriságot jelent az adott lókuszt tekintve. A földrajzi származás és a kapott klaszterek között nem találtak összefüggést. 


\subsubsection{Az SSR markerek genetikai diverzitás vizsgálatokban való alkalmasságának összevetése egyéb molekuláris technikákkal}

Goulão és Oliviera (2001) a mikroszatelliten alapuló módszerek (SSR és ISSR) és a RAPD és AFLP technikák használhatóságát hasonlította össze ugyanazon fajták vizsgálatba vonásával. A szomatikus mutációkból származó fajták kivételével az összes fajtát el tudták különíteni az SSR és ISSR markerekkel. A portugál fajták valamennyi vizsgálati módszer esetén a nemzetközi fajtáktól külön klaszterbe kerültek, ami azt mutatja, hogy ezeket a fajtákat nem vonták be a nemzetközi nemesítési programokba. Megállapították, hogy a négy alkalmazott technika eredményei korrelálnak egymással. Viszont a heterozigótaság a mikroszatelliten alapuló technikáknál jóval nagyobb volt, mint az AFLP és RAPD esetében, ezért alkalmasabbak a fajták megkülönböztetésére. A mikroszatelliten alapuló módszerek (SSR és ISSR) és a RAPD és AFLP technikák eredményei között pozitív korrelációt találtak $(r=0.558-0.737, p=1.00)$.

Muzher et al. (2007) szíriai fajtákon vizsgálta a genetikai variabilitást RAPD, AFLP és SSR markerekkel. A módszerek összehasonlításakor megállapították, hogy a legnagyobb polimorfizmust az SSR markerek adták, ezért a leghatékonyabb markernek tartják a diverzitásvizsgálatokhoz.

Garkava-Gustavsson et al. (2008) 68 régi svéd fajta genetikai ujjlenyomatát készítették el SSR és S-allél vizsgálatokkal, továbbá ez alapján felmérték a gyüjtemény genetikai diverzitását és a fajták származására is találtak lehetséges rokoni szálakat. A vizsgálatok során 21 egyedi allélt azonosítottak. Szignifikáns negatív korrelációt $(\mathrm{r}=-0.863, \mathrm{p}<0.0001)$ mutattak ki az SSR adatokon alapuló Roger-féle genetikai távolság és a Jaccard hasonlósági együttható mátrixok között. Ezzel szemben az SSR és a Garkava-Gustavsson és Nybom (2007) által korábban közölt RAPD fragmentumok Jaccard hasonlósági együtthatója között szignifikáns pozitív korrelációt találtak $(\mathrm{r}=0.377$, p<0.001).

\subsubsection{Rezisztenciagének SSR markerezése}

Az SSR-re alapozott kapcsoltsági térképek alapvető fontosságúak a varasodással, lisztharmattal és tüzelhalással szembeni rezisztencia főgének, illetve QTL-ek azonosításában és pozícionálásában. Az European D.A.R.E., EU-HiDRAS, COST 864 “'Pome Fruit Health” (2006-2011) stb. projektek keretén belül is sikeresen alkalmazták az SSR-eket markerfejlesztésre, a nemesítési programokban markerekre alapozott szelekcióra (MAS), vagy pl. a varasodás rezisztenciáért felelős főgének azonosítására (Kellerhals et al. 1999, 
Lespinasse et al. 2000, Gianfranceschi és Soglio 2004, Patocchi et al. 2009a, Kellerhals et al. 2012, Kumar et al. 2012).

A növények tűzelhalással (kórokozó: Erwinia amylovora (Burrill) Winslow et al.) szembeni ellenállósága QTL-en alapul, melyek térképezése napjainkban is folyamatban van. Már van néhány sikeresen használható SCAR és SSR marker, amelyek komplex használata esetén információt kaphatunk a fajták fogékonyságára vonatkozóan (Calenge et al. 2005, Peil et al. 2007, Khan et al. 2007, 2012, Gardiner et al. 2012, Nybom et al. 2012, Tóth et al. 2013).

A fajták lisztharmattal (kórokozó: Podosphaera leucotricha (Ellis \& Everh.) E.S. Salmon) szembeni ellenállósága összetett. Sikeresen azonosítottak fögéneket, de feltételezik a poligénes hátteret. Néhány főgénre már kifejlesztettek SCAR és SSR markereket, amelyeknek jelentős szerepe lehet a hibrid magoncok genotípuson alapuló korai szelekciójára (MAS) (James et al. 2004, Calenge and Durel 2006, Dunemann et al. 2004, Dunemann és Schuster 2009).

A ventúriás varasodással (kórokozó: Venturia inaequalis (Cooke) G. Wint.) szembeni rezisztencia szintén komplex, fő és mellékgének határozzák meg, s a rasszspecifikusság is bizonyítást nyert (Gessler et al. 2006). A legtöbb esetben a korábban monogénesnek hitt rezisztenciáról is bebizonyosodott a komplexitás. Az alma három legjelentősebb kórokozója közül a varasodás genetikai háttere a leginkább feltárt, és számos SCAR és SSR marker áll a kutatók rendelkezésére (Vinatzer et al. 2004, Bus et al. 2005, Galli et al. 2010, Patocchi et al. 2004, 2005, 2009b).

\subsubsection{Egyéb (növekedéssel, gyümölcsminőséggel kapcsolatos) tulajdonságok SSR markerezése}

A növekedéssel kapcsolatos tulajdonságok markerezése kevésbé népszerü, mint pl. a rezisztenciagének markerezése, hiszen az utóbbi a jelentős kártétel, és az ebből következő terméskiesés miatt rendkívül fontos. Néhány tanulmány az oszlopos növekedésért felelös géneket kutatta, és napjainkra már rendelkezésre állnak SSR markerek is, melyekkel korai szelekciót tudunk végezni (Hemmat et al. 1997, Moriya et al. 2009). Mások a fa magasságával, és egyéb növekedési jellemzőkkel kapcsolatos kvantitatív tulajdonságokhoz kerestek markereket (Conner et al. 1998, Liebhard et al. 2003a). Stoeckli et al. (2008) a növekedéssel és a levéltetü-rezisztenciával kapcsolatos QTL-eket, és az azokkal kapcsolt SSR markereket kereste.

A gyümölcsminőséggel kapcsolatos tulajdonságok szintén QTL háttérrel rendelkeznek. Ezek markerezése még nem rutinszerüen alkalmazott, mivel a pontos genetikai 
háttér még nem ismert. Különböző tanulmányokban azonban fellelhető néhány SSR marker, amely pl. a gyümölcsméret, húskeménység, lédússág, húsbarnulás, C-vitamin-tartalom, savasság stb. tulajdonságokkal kapcsolatos QTL-ek markerezésére használható (King et al. 2000, Liebhard et al. 2003a, Gianfranceschi és Soglio 2004, Oraguzie et al. 2004, Cevik et al. 2009, Kenis et al. 2008, Yao et al. 2008, Sun et al. 2012)

Viszonylag új kutatási téma a vörös gyümölcshús markerezése, amely tulajdonság szintén QTL-en alapul, térképezéséhez SSR markereket is használnak. Magoncok korai szelekciójára már elérhetők markerek (főként SCAR) (Chagné et al. 2007).

A térképezési programokban szintén jelentős szerepe van az SSR markereknek, amelyek pozícionálását a 17 kromoszómán már többen elvégezték (Liebhard et al. 2002, 2003b, Kenis és Keulemans, 2005, Silfverberg-Dilworth et al. 2006, Patocchi et al. 2009a). A teljes almagenom ('Golden Delicious’ fajta) szekvencia meghatározása kiváló lehetőséget jelent a DNS-polimorfizmusok felkutatására (Velasco et al. 2010).

\subsubsection{Standardizálás}

Alma esetében a különböző kutatómühelyek főleg Gianfrancheschi et al. (1998) és Liebhard et al. (2002) listájáról választanak SSR (CH-jelü) primereket, míg Új-Zélandon főként a Guilford et al. (1997) által fejlesztett NZ-, az USA-ban pedig a Hokanson et al. (1998) által fejlesztett GD-jelzésü markereket használják. Időnként a Hi-sorozatot (Silfverberg-Dilworth et al. 2006) és a COL jelüeket (Hemmat et al. 1997) is alkalmazzák. Mivel a különböző laboratóriumok eltérő SSR markerköröket használnak, ezért a tanulmányok sikeres összehasonlítása gyakran lehetetlen. Ez jelentős gondokat okoz, mert mind a kutatásoknak, mind a nemesítésnek pontosan meghatározott génbanki anyagra lenne szükségük.

Ezt a problémát az ECPGR (European Cooperative Programme for Crop Genetic Resources Network) Malus/Pyrus Munkacsoportja korán felismerte (King et al. 1998), és javasolták a markerek kiválasztását. Munkacsoportokat jelölt ki az SSR lókuszok szelektálására, amelyeket világszerte használni tudnak a laboratóriumok. Egy 2000-ben kezdett előtanulmányban 142 francia fajtán, kilenc SSR markert (CH01d03, CH02c06, CH02c09, CH01h02, CH04c06, CH04e05, COL, CH02c11, CH02d08) vizsgáltak (Laurens et al. 2004, Maggioni et al., 2004). A kilenc, első körben kiválasztott primer egy részét számos kutató (Guarino et al. 2006, Wichmann et al. 2010) nem javasolja, mert multilókuszosak, vagy kis polimorfizmus jellemzi őket.

Az ECPGR Malus/Pyrus Munkacsoportjának következő találkozóján, 2002-ben kiválasztották a kontroll fajtákat is: 'Golden Delicious', 'Fiesta' és 'Prima' (Maggioni et al. 
2004). 2006 májusában, az ECPGR harmadik Malus/Pyrus Munkacsoport találkozóján a 9 tesztelt markerböl 4 könnyen használható, és nagyfokú polimorfizmust mutató markert választottak ki: CH02c06, CH02c09, CH02c11 és CH04c06 (Laurens és Feugey 2010).

Közben Silfverberg-Dilworth et al. (2006) szintén három referenciafajta ('Fiesta', 'Discovery', 'Prima') használatát javasolta, amely fajták a legtöbb alma SSR markerrel már tesztelve lettek, és számos genetikai tanulmány magába foglalta azokat, mint a genetikailag térképezett populációk szülőfajtáját Európában. Javasolták, hogy a kontroll fajták fragmentumhosszát szekvenálással határozzák meg.

A 2006 decemberében tartott ad hoc ECPGR találkozón újabb primereket jelöltek ki. A körte és a cseresznye esetében az ECPGR (European Cooperative Programme for Crop Genetic Resources Network) már nyilvánosságra hozta a genetikai ujjlenyomat készítéshez javasolt standard SSR lókuszokat és fajtákat (Evans et al. 2009, Clarke és Tobutt 2009). Xuan et al. (2010) tesztelte az újonnan kijelölt 12 alma SSR markert 249 helyi és a 8 (szintén újonnan kijelölt) kontroll fajtán. Az ECPGR negyedik Malus/Pyrus Munkacsoport találkozóján, 2012 márciusában jóváhagyták ezt a 12 markert, és az alkalmazási módszereket, amelyet a közeljövőben elérhetővé tesznek (Lateur et al. 2013). Az ECPGR által fajtaazonosításra kijelölt markerkörben megtalálható 12 SSR marker a következő: CH01h10, CH04c07, CH01h01, Hi02c07, CH01f03b, GD147, CH01f02, GD12, CH02d08, CH04e05, CH02c11, CH02c09 (Xuan et al. 2010).

Garkava-Gustavsson et al. (2008) az újonnan javasolt standard markereket sikeresen alkalmazta a svéd fajtagyüjtemény fajtáinak vizsgálatakor. Néhány általuk használt SSR markert más kutató is használt, így össze tudták hasonlítani az eredményeket. Sehic et al. (2013) almafajtákra vonatkozó 31 nemzetközi kutatásban használt SSR markert és annak hivatkozásait foglalta össze táblázatos formában, amely felhívja a figyelmet az eltérő primerhasználatból adódó nehézségekre, hiszen a kijelölt SSR markerek és a közös adatbázis hiánya nagy akadályt jelent a génbanki azonosításban.

Számos félreértés adódik a markerkör folyamatos változtatásából. Pl. Wichmann et al. (2010) és Sikorskaite et al. (2012) az ECPGR által javasolt markerkört használta, de ezek az első (Maggioni et al. 2004), és nem a végleges kijelölésből származtak. Xuan et al. (2010) már az újonnan kijelölt primereket használta, pontosabban alkalmasságukat tesztelte. Potts et al. (2012) az előkísérletekben 17 SSR markert használtak (közülük 12-őt az ECPGR is javasolt), de a további elemzést már csak 10 lókuszon (ebből nyolc a kiemelt csoport része) végezték el. Baric et al. (2009) felhívja a figyelmet, hogy nem csupán a standard markerek és referenciafajták meghatározása fontos, hanem az alkalmazott protokollt is standardizálni kell az adatok összehasonlíthatósága érdekében. 
A legutóbbi ad hoc találkozó jegyzőkönyve szerint a Malus, Pyrus és Prunus SSR markerekre vonatkozó információkat 2013. március végén fogják közölni az ECPGR honlapján (Lateur et al. 2013). Ameddig a végleges listát és protokollt nem publikálják, számos további félreértések fordulhatnak elő, ráadásul nehéz a kutatási projektek tervezése, illetve az adatok összevetése, így a szinonimák kiszürése is nehezebb. Aztán a jövő kérdése lesz az, hogy a véglegesnek szánt lista valóban véglegesnek bizonyul-e.

\subsubsection{Online adatbázisok}

A HiDRAS projekt keretében végzett térképezési és markerfejlesztési munkák eredményei elérhetők az interneten is. A www.hidras.unimi.it oldalon, a Markers \& maps menüpontban a CH-, Hi-, NZ-, GD-sorozat SSR markereinek jellemzőit tudjuk megkeresni a marker neve, kapcsoltsági csoportja, típusa, kifejlesztője, a lókusz típusa alapján. Az egyes találatoknál megnézhetjük a primer szekvenciáját, hosszúságát, olvadási hőmérsékletét, a fenti tulajdonságokat, és a referencia publikációban közölt aléllszámot és a várt heterozigótasági értéket. Ezenkívül nyolc referenciafajta allélméreteit is megtalálhatjuk, ami segíti az adatok harmonizálását. Az oldalon saját adatok feltöltése és megjegyzések hozzáfüzése is lehetséges (Gianfrancheschi és Soglio 2004, Patocchi et al. 2009a).

GDR (Genom Database for Rosaceae) adatbázisban megtalálható szekvencia-adatok lehetőséget nyújtanak további SSR markerek tervezésére, a kódoló régiókban található mikroszatellit ismétlődések felhasználásával (Jung et al. 2008). A http://www.rosaceae.org oldalon megtekinthetjük és letölthetjük a Velasco et al. (2010) által publikált teljes almagenom-szekvenciát. Rákereshetünk a kromoszómák, gének, markerek és transzkriptomok adataira.

Magyar Alma Mikroszatellit Adatbázis (http://mkk.szie.hu/dep/genetika/Alma mikroszatellit/Uj/Fooldal.html) a Szent István Egyetemen végzett vizsgálatok eredményeit mutatja be. Megtalálhatjuk kereskedelmi világfajták és régi magyar fajták 6 SSR lókuszban mért allélméreteit, valamint a kapcsolódó publikációkat (Galli et al. 2005, Wichmann et al. 2007).

\subsection{A morfológiai és a molekuláris jellemzések együttes alkalmazása}

A fajták leírásához és azonosításához sokáig csak a fenotípusos tulajdonságokat, ezen belül is föként a gyümölcsök pomológiai jellemzését vették alapul. A környezeti tényezők fenotípusra gyakorolt hatása, és a hosszú juvenilis szakasz azonban megnehezíti ezeknek a vizsgálatoknak az elvégzését, és befolyásolja a pontosságát. Az almafajták UPOV által 
javasolt morfológiai markerekkel való leírásához ajánlott rendelkezni az összes példafajtával, vagy más termőhelyröl származó adatokat kell felhasználni, ami nem javasolt, vagy pedig jelentős szubjektivitást kell alkalmazni, ami rontja a vizsgálatok minőségét, ráadásul a vizsgálat időigényes (Santesteban et al. 2009). Éppen ezért a fásszárú gyümölcsfajok esetében kifejlesztették a DNS-szintü analízist, amit az 1990-es évek óta alkalmaznak az egyedi genetikai ujjlenyomat készítésére (Wünsch és Hormaza 2002, Zhang et al. 2012).

A nehézségek ellenére a génbanki gyüjtemény morfológiai jellemzése nagy jelentőséggel bír a termesztők és a nemesítők számára. Számos kutató felhívja a figyelmet arra, hogy a molekuláris adatokat célszerü kombinálni a morfológiai és egyéb fenotípusos tulajdonságokkal a pontosabb eredmények érdekében (Hokanson et al. 2001, Goerre 2001).

Royo és Itoiz (2004) javasolták a diverzitás vizsgálatok során mind a morfológiai, mind a molekuláris azonosítást, célszerü azonban a vizsgált fajták körét azokra csökkenteni, amelyeken mindkét módszert alkalmazzuk. Royo és Itoiz (2004) a RAPD, izoenzim és morfológiai markerek génbanki azonosításokra alkalmazhatóságát hasonlította össze almafajtákon. A RAPD és izoenzim markereket alkalmasnak találták a fajták közti különbségek kimutatására, és gyors vizsgálatot tesznek lehetővé. Az izoenzimek a variábilitás vizsgálatára önmagukban nem voltak alkalmasak, csak valamilyen molekuláris vizsgálattal kiegészítve. A három klaszterezési módszer közti korreláció meghatározására Mantel-tesztet végeztek. Az izoenzim és RAPD mátrixok között erős ( $r=0.73)$, míg a morfológiai és a másik két mátrix között gyenge ( $r=0.25$, ill. $r=0.27)$ korrelációt tapasztaltak.

Szalatnay et al. (2009), Pereira-Lorenzo et al. (2003, 2007), Santesteban et al. (2009) a morfológiai (főként UPOV és IPGRI) leírásokat kiegészítették izoemzim és/vagy molekuláris vizsgálatokkal is, aminek köszönhetően számos fajtakeveredést és szinonimát sikerült tisztázni. Federico et al. (2008) a morfológiai és molekuláris adatmátrixok között különbséget találtak, ami felhívja a figyelmet arra, hogy a morfológiai tulajdonságokat jelentősen befolyásolhatják a környezeti hatások, míg a DNS-alapú molekuláris markerek függetlenek a környezeti hatásoktól. 


\section{CÉLKITŰZÉS}

A PhD kutatásban kárpát-medencei származású, valamint külföldi származású, de a Kárpátmedencében elterjedt, régi almafajtákat vizsgáltuk a fajták jellemzése és a rokonsági viszonyaik felmérése érdekében. A dolgozat célja a régi almafajták fenológiai, morfológiai és genetikai sajátosságainak megfigyelése és értékelése az alábbi vizsgálatokon keresztül:

- Virágzásfenológiai sajátosságok megfigyelése és a fajták virágzási időcsoportokba sorolása.

- A génbanki gyűjtemény jellemzése és diverzitásának felmérése morfológiai és molekuláris markerek segítségével:

- számkulcsos jellemzés elkészítése az UPOV irányelvei szerinti morfológiai és biológiai tulajdonságok alapján,

- genetikai ujjlenyomat elkészítése 12 SSR marker használatával,

- a vizsgált gyüjtemény diverzitásának felmérése,

- a fajtacsoportokon belüli variabilitás értékelése, a fajtaváltozatok elkülönítése.

- A fenotípus és genotípus vizsgálatok eredményei közötti korreláció vizsgálata.

- A nemesítő által közölt szülő-utód kapcsolatok ellenőrzése SSR markerekkel.

- A hagyományos és molekuláris módszerek - különös tekintettel a fajtaazonosításra és a szinonimák azonosítására - használhatóságának értékelése a génbanki állomány kezelésében. 


\section{VIZSGÁLATOK ANYAGA ÉS MÓDSZERE}

\subsection{Vizsgálatba vont fajták}

A kontroll fajtákat nem számítva a fenológiai megfigyelésekbe 57, az UPOV morfológiai jellemzéshez 60, míg a molekuláris vizsgálatokba 73 különböző, a Kárpát-medencében fellelhető régi almafajtát/genotípust vontunk be (1. táblázat). 1948-ban Mohácsy Mátyás az egyetem egykori Kamaraerdei Törzsgyümölcsöséből magyar fajtákat küldött az Angol Nemzeti Fajtagyüjteménybe (Apple Collection at Brogdale in Kent). Ezt Tóth (2005a) visszahozta, és további gyüjtő utakat szervezett a Kárpát-medencében, melynek eredményeként a BCE Gyümölcstermő Növények Tanszék létrehozott egy fajtagyüjteményt. A vizsgálatainkba ezeket a magyar fajtákat, továbbá Kárpátalján, Erdélyben, az Aggteleki Nemzeti Park és a Mecsek területén szórványgyümölcsösökböl gyüjtött, magyar tájfajtákat és változatokat vontuk be a fajtaazonosítás és jellemezés miatt. A 'Fertődi téli' és a 'Budai Domokos' fajták pedigréjének vizsgálatához további fajták ('Jonathan', 'Téli arany parmen', 'Török Bálint') bevonása is szükséges volt. Néhány fajtánál a fajtaazonosság megkérdőjeleződött, így a genetikai vizsgálatokhoz több gyűjtési helyről származó mintát is

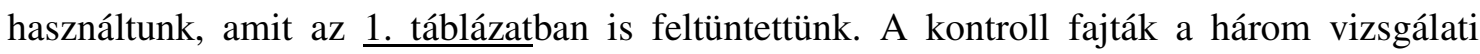
módszerben nem voltak azonosak, hanem az adott vizsgálathoz igazítottuk őket. A fenológiai megfigyelések során a virágzási időcsoportok alapján választottunk kontrollt Bodor et al. (2008) ajánlásait figyelembe véve. A morfológiai vizsgálatokhoz az UPOV (2005) által javasolt példafajtákat használtuk, amelyek megtalálhatók a TG/14/9 számú útmutatóban. A molekuláris vizsgálatokhoz a HiDRAS honlapján referencia fajtaként javasoltak közül a 'Florina', 'Gala', 'Prima' képezte a kontrollt, míg a 'McIntosh' és a 'Pinova' kontrollként alkalmazását az indokolja, hogy számos szakirodalom ezeket használja referencia fajtaként. 
1. táblázat. A különböző vizsgálatokban szereplö fajták listája és a származása

\begin{tabular}{|c|c|c|c|c|c|c|}
\hline Vizsgált fajta & Termőhely & $\begin{array}{c}\text { Eredeti begyüjtés } \\
\text { helye }^{*}\end{array}$ & $\begin{array}{l}\text { Szakirodalom } \\
\text { szerinti } \\
\text { származás } \\
\end{array}$ & $\begin{array}{c}\text { Fenológiai } \\
\text { vizsgálat }\end{array}$ & $\begin{array}{c}\text { Morfológiai } \\
\text { jellemzés } \\
\text { (UPOV) }\end{array}$ & $\begin{array}{c}\text { Marker- } \\
\text { analízis } \\
\text { (SSR) }\end{array}$ \\
\hline Bánffy Pál & Soroksár & Anglia & Erdély & $\mathrm{X}$ & $\mathrm{x}$ & $\mathrm{x}$ \\
\hline Batul 1 & Soroksár & Anglia & Erdély & $\mathrm{X}$ & $\mathrm{x}$ & $\mathrm{x}$ \\
\hline Batul 2 & Soroksár & Kárpátalja & Erdély & $\mathrm{x}$ & $\mathrm{x}$ & $\mathrm{x}$ \\
\hline Batul 3 & Soroksár & Kárpátalja & Erdély & $\mathrm{x}$ & $\mathrm{x}$ & $\mathrm{x}$ \\
\hline Baumann renet & Soroksár & Kárpátalja & Franciaország & $\mathrm{X}$ & $\mathrm{x}$ & $\mathrm{x}$ \\
\hline Beregi sóvári 1. & Soroksár & Anglia & Kárpátalja & $\mathrm{x}$ & $\mathrm{x}$ & $\mathrm{x}$ \\
\hline Beregi sóvári 2. & Soroksár & Kárpátalja & Kárpátalja & $\mathrm{x}$ & $\mathrm{x}$ & $\mathrm{x}$ \\
\hline Bőrkormos renet & Soroksár & Kárpátalja & $?$ & $\mathrm{x}$ & $\mathrm{x}$ & $\mathrm{x}$ \\
\hline Budai Domokos & Soroksár & Erdély & Erdély & $\mathrm{X}$ & $\mathrm{x}$ & $\mathrm{x}$ \\
\hline Budai Domokos & Fadd & & Erdély & & & $\mathrm{x}$ \\
\hline Budai Domokos & Újfehértó & & Erdély & & & $\mathrm{x}$ \\
\hline Budai Ignác & Soroksár & Anglia & Erdély & $\mathrm{X}$ & $\mathrm{x}$ & $\mathrm{x}$ \\
\hline Cigány alma & Soroksár & Anglia & Németország & $\mathrm{x}$ & $\mathrm{x}$ & $\mathrm{x}$ \\
\hline Cserepánya & Soroksár & Kárpátalja & Kárpátalja & $\mathrm{x}$ & $\mathrm{x}$ & $\mathrm{x}$ \\
\hline Csíkos óriás halasi & Soroksár & Anglia & $?$ & $\mathrm{x}$ & $\mathrm{x}$ & $\mathrm{x}$ \\
\hline Dániel féle renet & Soroksár & Anglia & Németország & $\mathrm{x}$ & $\mathrm{x}$ & $\mathrm{x}$ \\
\hline Daru sóvári & Soroksár & Anglia & Kárpátalja & $\mathrm{x}$ & $\mathrm{x}$ & $\mathrm{x}$ \\
\hline Édes escoar & Soroksár & Kárpátalja & $?$ & $\mathrm{x}$ & $\mathrm{x}$ & $\mathrm{x}$ \\
\hline Entz Rozmaring & Soroksár & Anglia & Alföld & $\mathrm{x}$ & $\mathrm{x}$ & $\mathrm{x}$ \\
\hline Fehér batul & Fadd & & Erdély & & & $\mathrm{x}$ \\
\hline Fekete tányéralma & Soroksár & Anglia & Erdély & $\mathrm{X}$ & $\mathrm{x}$ & $\mathrm{x}$ \\
\hline Fertődi téli & Pölöske & & Magyarország & & & $\mathrm{xx}$ \\
\hline Fertődi téli & Szigetcsép & & Magyarország & & & $\mathrm{xx}$ \\
\hline Florina & Soroksár & $\begin{array}{l}\text { hazai } \\
\text { oltványforgalmazás }\end{array}$ & Franciaország & $\mathrm{xxx}$ & & $\mathrm{XxX}$ \\
\hline Gala & Soroksár & $\begin{array}{l}\text { hazai } \\
\text { oltványforgalmazás }\end{array}$ & Új-Zéland & & & $\mathrm{XXX}$ \\
\hline Gegesi piros & Soroksár & Erdély & Erdély & $\mathrm{x}$ & $\mathrm{x}$ & $\mathrm{x}$ \\
\hline Gomba Károly & Soroksár & Anglia & Erdély & $\mathrm{X}$ & $\mathrm{x}$ & $\mathrm{x}$ \\
\hline Gyógyi piros & Soroksár & Anglia & Erdély & $\mathrm{x}$ & $\mathrm{x}$ & $\mathrm{x}$ \\
\hline Harang alma & Soroksár & Anglia & Alföld & $\mathrm{x}$ & $\mathrm{x}$ & $\mathrm{x}$ \\
\hline Herceg Batthyány & Soroksár & Anglia & Dunántúl & $\mathrm{x}$ & $\mathrm{x}$ & $\mathrm{x}$ \\
\hline Honti alma & Fadd & Aggtelek & Felvidék & & & $\mathrm{x}$ \\
\hline Honti alma & Fadd & Garamente & Felvidék & & & $\mathrm{x}$ \\
\hline Hosszúfalusi & Soroksár & Anglia & $?$ & $\mathrm{X}$ & $\mathrm{x}$ & $\mathrm{x}$ \\
\hline Húsvéti rozmaring & Soroksár & $\begin{array}{l}\text { hazai } \\
\text { oltványforgalmazás }\end{array}$ & Alföld & & $\mathrm{x}$ & $\mathrm{x}$ \\
\hline Ízletes zöld & Soroksár & Anglia & Erdély & $\mathrm{x}$ & $\mathrm{x}$ & $\mathrm{x}$ \\
\hline Jászvadóka & Soroksár & Anglia & Alföld & $\mathrm{x}$ & $\mathrm{x}$ & $\mathrm{x}$ \\
\hline Jonathan & Soroksár & Szigetcsép & USA & & & $\mathrm{xx}$ \\
\hline Kanadai renet 1 & Soroksár & Kárpátalja & Franciaország & $\mathrm{x}$ & $\mathrm{x}$ & $\mathrm{x}$ \\
\hline Kanadai renet 2 & Soroksár & Kárpátalja & Franciaország & $\mathrm{x}$ & $\mathrm{x}$ & $\mathrm{x}$ \\
\hline Kanadai renet 3 & Soroksár & Kárpátalja & Franciaország & $\mathrm{x}$ & $\mathrm{x}$ & $\mathrm{x}$ \\
\hline Királyi renet & Soroksár & Aggtelek & Franciaország & $\mathrm{x}$ & $\mathrm{x}$ & $\mathrm{x}$ \\
\hline Kisasszony & Soroksár & Kárpátalja & Kárpátalja & $\mathrm{x}$ & $\mathrm{x}$ & $\mathrm{x}$ \\
\hline Lóci cirmos alma & Soroksár & Erdély & $?$ & $\mathrm{x}$ & $\mathrm{x}$ & $\mathrm{x}$ \\
\hline Lóci édes almája & Soroksár & Erdély & $?$ & $\mathrm{x}$ & $\mathrm{x}$ & $\mathrm{x}$ \\
\hline Londoni pepin & Soroksár & Kárpátalja & Anglia & $\mathrm{x}$ & $\mathrm{x}$ & $\mathrm{x}$ \\
\hline Marosszéki piros & Soroksár & Anglia & Erdély & $\mathrm{x}$ & $\mathrm{x}$ & $\mathrm{x}$ \\
\hline Masánszki & Soroksár & Erdély & Németország & $\mathrm{x}$ & $\mathrm{x}$ & $\mathrm{x}$ \\
\hline Máté Dénes & Soroksár & Anglia & $?$ & $\mathrm{x}$ & $\mathrm{x}$ & $\mathrm{x}$ \\
\hline McIntosh & Soroksár & $\begin{array}{l}\text { hazai } \\
\text { oltványforgalmazás }\end{array}$ & Kanada & & & $\mathrm{XXX}$ \\
\hline Mosolygós batul & Soroksár & Erdély & Erdély & $\mathrm{x}$ & $\mathrm{X}$ & $\mathrm{x}$ \\
\hline
\end{tabular}


1. táblázat (folyt). A különböző vizsgálatokban szereplő fajták listája és a származása

\begin{tabular}{|c|c|c|c|c|c|c|}
\hline Vizsgált fajta & Termóhely & $\begin{array}{c}\text { Eredeti begyüjités } \\
\text { helye* }^{*}\end{array}$ & $\begin{array}{c}\text { Szakirodalom } \\
\text { szerinti } \\
\text { származás } \\
\end{array}$ & $\begin{array}{c}\text { Fenológiai } \\
\text { vizsgálat }\end{array}$ & $\begin{array}{l}\text { Morfológiai } \\
\text { jellemzés }\end{array}$ & $\begin{array}{c}\text { Marker- } \\
\text { analízis } \\
\text { (SSR) }\end{array}$ \\
\hline Nemes sóvári & Soroksár & Kárpátalja & Kárpátalja & $\mathrm{x}$ & $\mathrm{x}$ & $\mathrm{x}$ \\
\hline $\begin{array}{l}\text { Nemes sóvári } \\
\text { (Sóvári nobil) }\end{array}$ & Soroksár & Anglia & Kárpátalja & $\mathrm{x}$ & $\mathrm{x}$ & $\mathrm{x}$ \\
\hline Nemes szercsika & Soroksár & Anglia & Délvidék & $\mathrm{x}$ & $\mathrm{x}$ & $\mathrm{x}$ \\
\hline Nyári fontos & Soroksár & & $\begin{array}{l}\text { Franciaország / } \\
\text { Magyarország ? }\end{array}$ & & $\mathrm{x}$ & $\mathrm{x}$ \\
\hline Ontario & Soroksár & & Kanada & $\mathrm{x}$ & $\mathrm{x}$ & $\mathrm{x}$ \\
\hline Orbai alma & Soroksár & Anglia & Erdély & $\mathrm{x}$ & $\mathrm{x}$ & $\mathrm{X}$ \\
\hline Pinova & Soroksár & Drezda-Pillnitz & Németország & & & $\mathrm{xxx}$ \\
\hline Prima & Soroksár & Szigetcsép & USA & & & $\mathrm{xxx}$ \\
\hline Reglindis & Soroksár & Drezda-Pillnitz & Németország & $\mathrm{xxx}$ & & \\
\hline Rewena & Soroksár & Drezda-Pillnitz & Németország & $\mathrm{xxx}$ & & \\
\hline Sándor cár & Soroksár & Erdély & Oroszország & $\mathrm{x}$ & $\mathrm{x}$ & $\mathrm{x}$ \\
\hline Sárga szépvirágú & Soroksár & Erdély & USA & $\mathrm{x}$ & $\mathrm{x}$ & $\mathrm{x}$ \\
\hline Sikulai & Soroksár & Anglia & Erdély & $\mathrm{x}$ & $\mathrm{x}$ & $\mathrm{x}$ \\
\hline Simonffy piros & Soroksár & Anglia & Alföld & $\mathrm{x}$ & $\mathrm{x}$ & $\mathrm{x}$ \\
\hline $\begin{array}{l}\text { Szabadkai } \\
\text { szercsika }\end{array}$ & Soroksár & Anglia & Délvidék & $\mathrm{x}$ & $\mathrm{x}$ & $\mathrm{X}$ \\
\hline Szászpap alma & Soroksár & Anglia & Erdély & $\mathrm{x}$ & $\mathrm{x}$ & $\mathrm{x}$ \\
\hline Széchenyi renet & Soroksár & Anglia & Dunántúl & $\mathrm{x}$ & $\mathrm{x}$ & $\mathrm{x}$ \\
\hline Tartós Gusztáv & Soroksár & Erdély & Svájc & $\mathrm{x}$ & $\mathrm{x}$ & $\mathrm{x}$ \\
\hline Téli arany parmen & Pölöske & & Franciaország & & & $\mathrm{xx}$ \\
\hline Téli arany parmen & Szigetcsép & $\begin{array}{l}\text { hazai } \\
\text { oltványforgalmazás }\end{array}$ & Franciaország & & & $\mathrm{xx}$ \\
\hline Téli sóvári & Fadd & & Kárpátalja & & & $\mathrm{x}$ \\
\hline Tordai alma & Soroksár & Anglia & Erdély & $\mathrm{x}$ & $\mathrm{x}$ & $\mathrm{x}$ \\
\hline Tordai piros kálvil & Soroksár & Anglia & Erdély & $\mathrm{x}$ & $\mathrm{x}$ & $\mathrm{x}$ \\
\hline Török Bálint & Törökbálint & & Németország / & & & $\mathrm{xx}$ \\
\hline Török Bálint & Újfehértó & & Magyarország ? & & & $\mathrm{xx}$ \\
\hline Tükör alma & Soroksár & Anglia & Alföld & $\mathrm{x}$ & $\mathrm{x}$ & $\mathrm{x}$ \\
\hline Vajki alma & Soroksár & Anglia & Felvidék & $\mathrm{x}$ & $\mathrm{x}$ & $\mathrm{x}$ \\
\hline Vilmos renet & Soroksár & Kárpátalja & Kárpátalja & $\mathrm{x}$ & $\mathrm{x}$ & $\mathrm{x}$ \\
\hline Zöld batul & Soroksár & Erdély & Erdély & $\mathrm{x}$ & $\mathrm{x}$ & $\mathrm{x}$ \\
\hline Zöld sóvári & Soroksár & Kárpátalja & Kárpátalja & & $\mathrm{x}$ & $\mathrm{x}$ \\
\hline
\end{tabular}

\subsection{Szabadföldi vizsgálatok helyszíne}

A vizsgálatok alapját képező génbanki és fajtagyüjtemények a BCE Gyümölcstermő Növények Tanszék soroksári kísérleti telepén (ÉSZ 4700', KH 19¹5') találhatók. A szabadföldi megfigyeléseket (fenológia és morfológia) 2007-2011-ben végeztük. Az ültetvényt 2001-ben telepítették, MM106-os alanyon szabadorsó koronaformát kialakítva (1. ábra). Az ültetvény egy részében (első 10 sorban) 5 x 2,5 m térállásban, összesen négy fa/fajta található, 2 x 2-es blokkokban, két szomszédos sorban egymás mellett elhelyezve. Az ültetvény kisebbik részén (11-13. sor) 3,5 x 1,2 m térállásban, fajtánként 3 fa található, egy 
soron belül blokkosítva. Az ültetvény kiépített öntözőrendszerrel rendelkezik, és integrált növényvédelmet alkalmaznak.

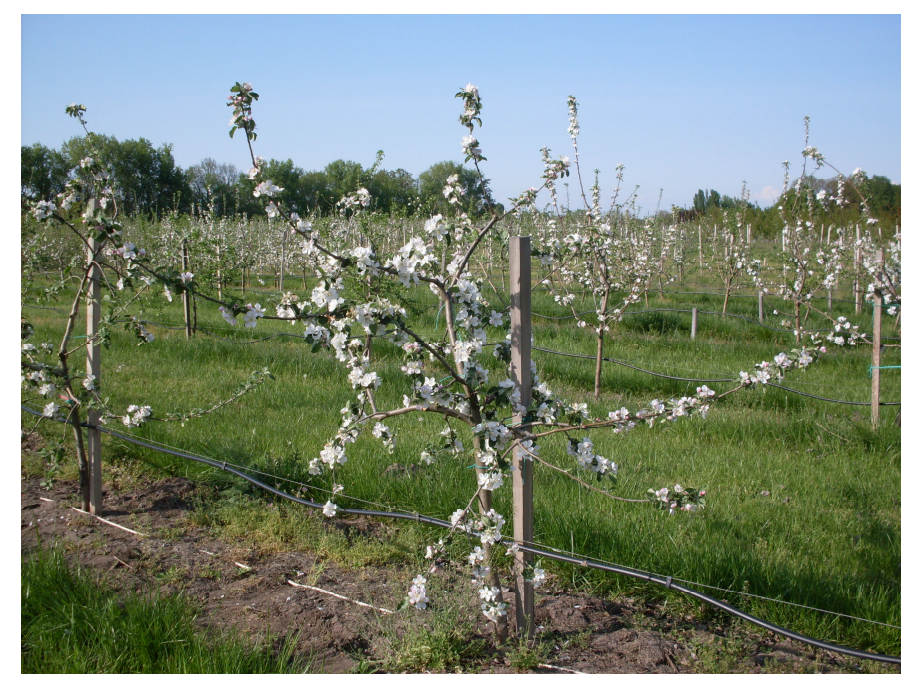

1. ábra. A történelmi fajtagyüjtemény virágzáskor (Soroksár, 2009).

Soroksár az Alföld északnyugati részén, a Duna öntésterületén helyezkedik el, így a talajok nagy része a Duna meszes homokhordalékán képződött. A területre jellemző a száraz, gyakran aszályos alföldi klíma. Szász és Tőkei (1997) szerint a terület évi átlaghőmérséklete $11,3{ }^{\circ} \mathrm{C}$, napsütéses órák száma 2079 óra, az átlagos éves csapadékmennyiség $560 \mathrm{~mm}$. 2010es talajvizsgálati adataink szerint az ültetvény talaja alacsony kalciumtartalmú $(2,44 \%)$ homokos vályogtalaj, a szénsavas mésztartalom 5,04\%. A talaj pH-ja 7,86, Arany-féle kötöttsége $(\mathrm{KA})<30$, a humusztartalom $0,891 \%$, amit a talajvizsgálatot követően vinaszozással javítottunk.

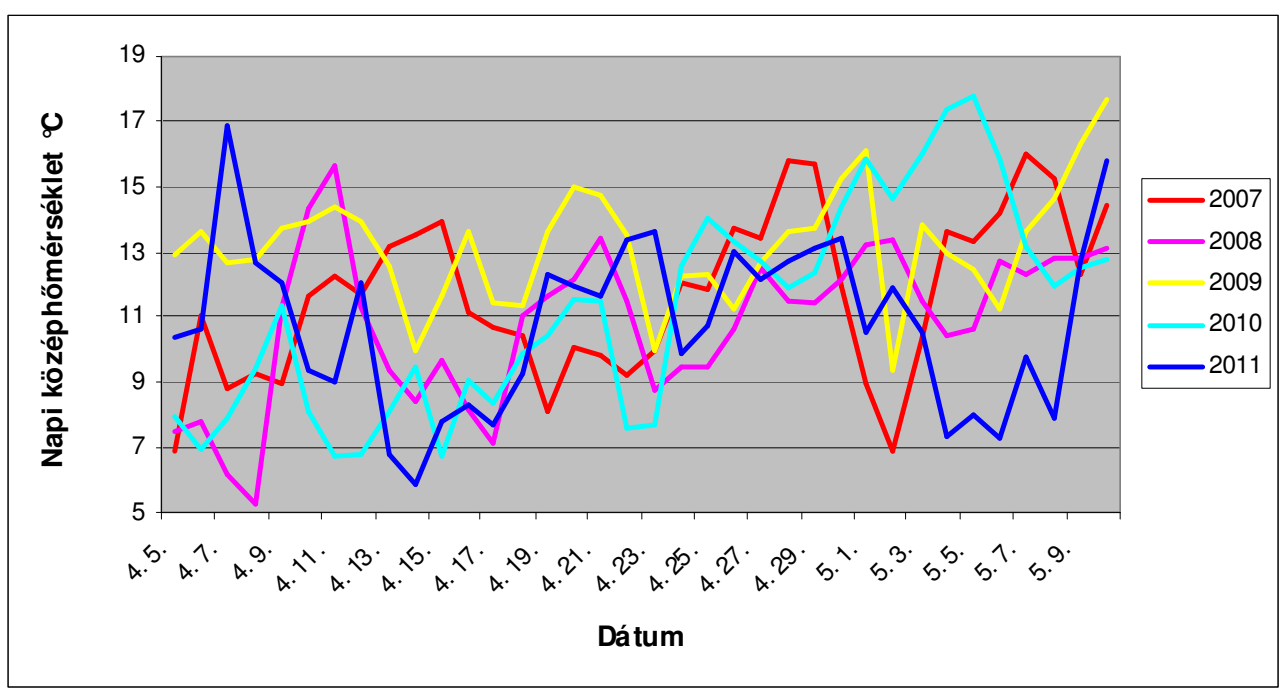

2. ábra. A Kísérleti Üzemben mért hőmérsékleti átlagértékek (Soroksár, 2007-2011). 
Az öt vizsgálati év virágzási időszakában mért hőmérsékleti adatokat a $\underline{2}$ a ábrán grafikusan ábrázolva mutatjuk be. A meteorológiai adatok a Soroksári Kísérleti Üzemben elhelyezett mérőállomás online adatbázisából származnak (Pessl Instrument 2009). Jelentősebb mennyiségü csapadék egyik vizsgálati évben sem volt a virágzást megelőző és a virágzás időszakában, így az adatokat nem ismertetjük.

\subsection{Fenotípus vizsgálatok}

\subsubsection{Fenológiai megfigyelések}

A virágzásfenológiai megfigyeléseket 2007-2011-ben végeztük a fent megjelölt génbanki ültetvényben. A virágzást közvetlenül megelőző fenofázisokat (zöld bimbós és piros bimbós stádium) is megfigyeltük, amely alapján felkészülhetünk a virágzáskor végzett megfigyelésekre. Virágzás idején kétnaponta végeztünk felméréseket a fajtagyüjteményben a virágzás tartamának és a fővirágzás idejének minél pontosabb meghatározása érdekében. Szubjektív megfigyeléssel, az UPOV irányelveinek megfelelően virágzás kezdetének (UPOV TG/14/9 - 55. jellemző) azt az időpontot tekintettük, amikor a virágok $10 \%$-a teljesen kinyílt állapotban volt. A DUS-teszt során csak a virágzás kezdetét kell meghatározni, így az UPOV nem ad a fővirágzásra és a virágzás végére meghatározást. Fővirágzásnak tekintettük azt az időpontot, amikor a kinyílt virágok aránya a legnagyobb volt (Ifjú, 1980), míg a virágzás végének, amikor a virágok 100 \%-a elvirágzott (Nyéki 1989).

A megfigyelt Gergely naptári napokat január 1-től számítva átalakítottuk Julián nappá (pl. január 1.=1, ..., április 12.=102), és a több éves adatok rangszámátlaga alapján állítottuk fel a virágzási sorrendet a fajták között. A rangszámátlag szerint sorba rendezett fajtákat a kontroll fajták relatív virágzási ideje alapján soroltuk virágzási időcsoportokba.

A stabil virágzási idejű kontroll (referencia) fajtákat Bodor et al. (2008) ajánlása alapján választottuk ki a leggyakoribb virágzási időcsoportokhoz: 'Reglindis' (korai), 'Florina' (közepes), 'Rewena' (kései). Öt virágzási időcsoportba soroltuk a fajtákat: nagyon korai (1), korai (3), közepes (5), kései (7), nagyon kései (9) virágzású. Az UPOV a fenológiai tulajdonságokat mennyiségi tulajdonságként kezeli, így ezeket 9 kifejeződési fokozatba lehetne sorolni, és a kiemelt fokozatokon túlmenően (1-3-5-7-9) köztes értéket is meglehet adni (2-4-6-8). Azonban ha az 5 helyett 9 kifejeződési fokozatba soroljuk a fajtákat, akkor az nehezítené az értékelést és a munka további felhasználhatóságát, így az értékelés során csak a kiemelt fokozatokat használtuk.

Az UPOV irányelve a virágzás kezdete alapján sorolja virágzási időcsoportba a fajtákat, viszont Soltész (1996) szerint a fővirágzás alapján kialakított csoportosítás sokkal 
informatívabb, és gyakrabban alkalmazzák, mert a fajták együttvirágzása, illetve kölcsönös pollenellátása szempontjából a fővirágzás a legmeghatározóbb. A szakirodalmi összevetés érdekében a virágzási sorrendet, illetve a virágzási időcsoportokat a virágzás kezdete és a fővirágzás alapján is kialakítottuk. Az UPOV (2005) irányelvei szerint a virágzás kezdete alapján 5 csoportba sorolhatjuk a fajtákat: nagyon korai, korai, közepes, kései és nagyon kései.

A fenológiához kapcsolódó gyümölcstulajdonság a szedési és a fogyasztási érettség időpontja. Az UPOV (2005) irányelveinek megfelelően a szedési érettség esetében öt, a fogyasztási érettség esetében pedig kilenc kifejeződési fokozatba soroltuk a fajtákat a nagyon koraitól a nagyon késői érésű kategóriáig.

\subsubsection{Morfológiai megfigyelések}

A morfológiai leírást az UPOV TG/14/9 szempontjai alapján végeztük. Összesen 53 morfológiai tulajdonságot figyeltünk meg a nyugalmi és a vegetációs periódusban (2. táblázat). Megfigyelési adatokat rögzítettünk lomb nélküli állapotban, virágzáskor, intenzív hajtásnövekedés végén és gyümölcséréskor. Az összes megfigyelt tulajdonságot és a

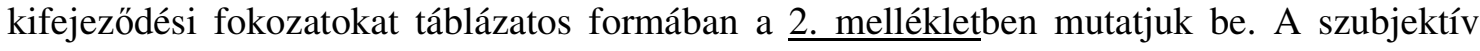
megfigyelések mellett mért adatokkal is dolgoztuk, amely során fajtánként 20-20 db virágot, levelet, gyümölcsöt vizsgáltunk. A vizsgálatokhoz a mintákat véletlenszerüen gyűjtöttuik 3 vagy 4 fáról, virágzatonként, illetve hajtásonként legfeljebb 1 mintát gyüjtve. A vizsgálatokat 2007 és 2011 között végeztük, minden fajta esetében legalább két évben végeztünk megfigyeléseket. Fontos, hogy a többéves kifejeződési fokozatokat ne átlagoljuk, hanem minden évben külön-külön végezzük el a kategóriába sorolást. A DUS-tesztek során az UPOV legalább két vizsgálati évet ír elő. Ha a két év adatai alapján nem végezhető el egyértelmüen a kifejeződési fokozatba sorolás, további 1-2 vizsgálati év szükséges az egyértelmü besoroláshoz.

2. táblázat. A különböző növényi részeken megfigyelt és mért tulajdonságok száma

\begin{tabular}{lccc}
\hline \multicolumn{1}{c}{ Megfigyelt tulajdonságok } & \multicolumn{3}{c}{ Tulajdonságok száma } \\
\cline { 2 - 4 } & mért & megfigyelt & összesen \\
\hline I. Morfológiai jellemzés & & 9 & 9 \\
- fa, vesszö & 3 & 6 & 9 \\
- levél & 1 & 3 & 4 \\
- virág & 2 & 29 & 31 \\
- gyümölcs & & 3 & 3 \\
II. Fenológiai megfigyelés & & & 56 \\
\hline Összesen & & & \\
\hline
\end{tabular}

Az UPOV a mért adatok kifejeződési fokozatba sorolására két módszer alkalmazását javasolja. Az egyik, hogy minden évben megmérjük a példafajtákat is, és ezek alapján 
végezzük el a besorolást. A másik módszer akkor alkalmazható, ha nagy diverzitású fajtagyüjteményben végezzük a vizsgálatokat, és nem áll rendelkezésünkre az UPOV által ajánlott összes példafajta. Mi ezt az utóbbi módszert alkalmaztuk a mérésen alapuló tulajdonságok számkódos rendszerbe konvertálására. Az éves adatok alapján évenként különkülön megállapítottuk az adott évben adott tulajdonságnál mért legkisebb és legnagyobb átlagértéket, és a különbséget lineáris skálán felosztottuk annyi részre, ahány UPOV kategória van az adott tulajdonságra. Ezzel meghatároztuk az egyes kategóriákhoz tartozó határértékeket, amely alapján a kifejeződési fokozatba sorolást végezhetjük. A megfigyelt és a mért többéves adatok alapján alakítottuk ki a fajták végleges számkulcsos besorolását.

\subsubsection{Fa és vessző morfológiai vizsgálata}

Nyugalmi állapotban, kora tavasszal végeztük a fa és vessző jellemzőinek felmérését. A kvantitatív tulajdonságokat szubjektív megfigyelés alapján soroltuk be a kifejeződési fokozatokba. A megfigyeléseket 3 vagy 4 fán végeztük, a vizsgált tulajdonságnak megfelelően a vessző középső vagy felső harmadát figyelembe véve. Feljegyeztük a fa növekedési erélyét (nagyon gyenge, gyenge, közepes, erős), terméshozási típusát (csak termőnyársakon, termőnyársakon és hosszú vesszőkön, csak hosszú vesszőkön), és a fa típusát (oszlopos, elágazó). Az elágazó típusú fajtáknál habitus alapján négy kifejeződési fokozatba soroltuk a fajtákat: feltörő, elterülő, lehajló, csüngő.

A vesszőn megfigyelt tulajdonságok a következők: vastagság (vékony, közepes, vastag, nagyon vastag), ízköz hosszúsága (nagyon rövid, rövid, közepes, hosszú), szín a napos oldalon (zöldes-, pirosas-, világos-, közép-, sötétbarna), szőrözöttség a vessző felső felén (nincs vagy nagyon gyenge, gyenge, közepes, erős, nagyon erős) és a paraszemölcsök száma (kevés, közepes, sok).

\subsubsection{Levélmorfológiai vizsgálatok}

A vizsgálatokhoz a leveleket az intenzív hajtásnövekedés végén szedtük 2007-2009-ben. Véletlenszerü mintavétellel, fajtánként 20-20 db levelet gyüjtöttünk 3 vagy 4 fáról, hajtásonként legfeljebb 1 mintát gyüjtve az erős növekedésü hajtások középső harmadáról. Vonalzóval mértük a kiterített levéllemez hosszúságát és szélességét, továbbá a levélnyél hosszát. Mivel a két évben az átlagértékek minimuma és maximuma között alig tapasztaltunk eltérést (max. 1-2 mm), ezért nem készítettünk külön skálát a két vizsgálati évre. A levéllemez hosszúsága szerint a következő kategóriákat állítottuk fel: nagyon rövid (<77 mm), rövid (77-85 mm), közepes (86-95 mm), hosszú (>95 mm). A levéllemez szélességére felállított kategóriák: keskeny (<56 mm), közepes (56-64mm), széles (>64mm). A levélnyél 
kategóriákat az alábbiak szerint állapítottuk meg: rövid (<20 mm), közepes $(21-27 \mathrm{~mm})$, hosszú (>27 mm).

A levéllemez hosszúság/szélesség arányából számoltuk a levél alakindexet. Feljegyeztük a levéllemez hajtáshoz viszonyított állását (felálló, kiálló, csüngő), a levelek zöld színének intenzitását (világos, közepes, sötét), a levéllemez szélének bemetszését a levél felső felét figyelembe véve (csipkés, kétszeresen csipkés, fürészes 1. típusú, fürészes 2. típusú, kétszeresen fürészes) (3. melléklet), a szőrözöttségét a fonákon (nincs vagy nagyon gyenge, közepes, erős) és a levélnyél antociános színeződésének kiterjedését az alaptól (kicsi, közepes, nagy).

\subsubsection{Virágmorfológiai vizsgálatok}

Fajtánként 20-20 db virágot vizsgáltunk. A vizsgálatokhoz a mintákat véletlenszerüen gyüjtöttük 3 vagy 4 fáról, virágzatonként legfeljebb 1 oldalsó helyzetü virágot gyüjtve. Fővirágzás állapotában lévő fákon a sziromlevelek egy síkba kiterítése után, vonalzóval mértük az oldalsó helyzetü virágok átmérőjét, s ez alapján méretkategóriákba soroltuk be a fajtákat. 2007 és 2008-ban tudtuk a legtöbb fajta virágát lemérni, míg 2009-ben csak a Batul és Sóvári fajtacsoportba tartozó fajtákat vizsgáltuk. 2010-ben nem végeztünk pontos méréseket, hanem szubjektív megfigyelés alapján kategorizáltuk a fajtákat. Mint az előző fejezetben utaltunk rá, a mért adatok kategóriába sorolását évente végeztük, és az így kapott értékek alapján végeztük a fajták végleges besorolását. A 2007- és 2008-as év kifejeződési fokozatainak határértékeit a 3. táblázatban mutatjuk be. Mivel 2009-ben csak kevés fajtát mértünk, nem tudtunk reális méretkategóriákat kialakítani, ezért a besorolásnál a 2008-as skálát használtuk.

3. táblázat. A virágok átmérője alapján kialakított kifejeződési fokozatok

\begin{tabular}{lcccc}
\hline \multirow{2}{*}{$\mathbf{E} v$} & \multicolumn{4}{c}{ Kifejeződési fokozat } \\
\cline { 2 - 5 } & nagyon kicsi & kicsi & közepes & nagy \\
\hline 2007 & $<42 \mathrm{~mm}$ & $42-48 \mathrm{~mm}$ & $49-54 \mathrm{~mm}$ & $>54 \mathrm{~mm}$ \\
2008 & $<45 \mathrm{~mm}$ & $45-52 \mathrm{~mm}$ & $53-59 \mathrm{~mm}$ & $>59 \mathrm{~mm}$ \\
\hline
\end{tabular}

A virágokon az átmérő mellett az alábbi tulajdonságokat jegyeztük fel: a virágok színe szirombimbó állapotban (fehér, sárgás rózsaszín, világos rózsaszín, sötét rózsaszín, középpiros, sötétpiros, bíborszínü), sziromlevelek elrendeződése (szabadon álló, közbülső, átfedő), bibék helyzete a portokokhoz viszonyítva (alattuk, egy szintben, felettük). 


\subsubsection{Gyümölcsmorfológiai vizsgálatok}

2007-2011 években végeztük a gyümölcsök morfológiai leírását. A gyümölcsöket az optimális szüreti időpontban szedtük le. A méréseket közvetlenül a szedés után vagy rövid idejű tárolás után végeztük el. Tolómérővel mértük a gyümölcsök magasságát és átmérőjét, a többi vizsgált tulajdonságot szubjektív megfigyelés alapján soroltuk be kifejeződési fokozatokba. A gyümölcs magasságát és átméröjét csak abban az esetben mértük, ha az adott fajtából legalább egy rekesznyi gyümölcs állt rendelkezésünkre. Ebből véletlenszerü mintavétellel 20 darab gyümölcsöt mértünk le.

Az öt vizsgálati év adatainak minimum és maximum átlagértékei csekély eltérést mutattak (max. 5-7 mm), ezért a kifejeződési fokozatokba besorolást egységes skála alapján végeztük. A gyümölcs magassága alapján kicsi (<55 mm), közepes (55-65 mm) és nagy (>65 mm), míg a gyümölcs átméröje alapján szintén a kicsi $(<70 \mathrm{~mm})$, közepes $(70-80 \mathrm{~mm})$ és nagy (>80 mm) kifejeződési fokozatokat alakítottuk ki. A gyümölcsök jellemzését összesen 31 (ebből kettő mérésen alapult) morfológiai tulajdonság alapján végeztük a következő tulajdonságcsoportok alapján: a gyümölcs alakjára, felszínére, kocsány- és csészemélyedésre, gyümölcshúsra és a magházra vonatkozó jellemzők. Az egyes tulajdonságok kifejeződési

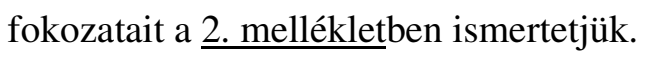

A gyümölcsök alakjával kapcsolatos vizsgált tulajdonságok:

- méret;

- magasság;

- átmérö;

- magasság/átmérő aránya;

- alak (4. melléklet).

A gyümölcsök felszínén megfigyelt tulajdonságok:

- bordázottság;

- héj hamvassága;

- héj zsírossága;

- alapszín;

- fedőszín viszonylagos felülete;

- fedőszín árnyalata - hamvasság letörlése után;

- fedőszín intenzitása;

- fedőszín jellege;

- csíkok szélessége;

- parásodás felülete a gyümölcs oldalán;

- paraszemölcsök száma;

- paraszemölcsök mérete.

A kocsány- és csészemélyedés környékén megfigyelt tulajdonságok:

- kocsány hosszúsága;

- kocsány vastagsága; 
- parásodás felülete a kocsány körül;

- kocsánymélyedés mélysége;

- kocsánymélyedés szélessége;

- barázdáltság a csészemélyedés szélén;

- csésze mérete;

- csészelevél hosszúsága;

- parásodás felülete a csészemélyedés körül;

- csészemélyedés mélysége;

- csészemélyedés szélessége.

A gyümölcshúsra és magházra vonatkozó tulajdonságok:

- hús szilárdsága;

- hús színe;

- magrekeszek nyitottsága (keresztmetszetben).

\subsection{Genetikai vizsgálatok}

A markeranalízist a Budapesti Corvinus Egyetem Gyümölcstermő Növények Tanszék Molekuláris biológiai laboratóriumában végeztük. A markeranalízisbe vont fajtákat az $\underline{1}$. táblázat tartalmazza. Belső kontrollként a 'Prima', referenciafajtaként pedig további négy ('Florina', 'Gala', 'McIntosh', 'Pinova') fajtát is használtunk, annak érdekében, hogy eredményeink más kutatómühelyek eredményeivel összevethetők legyenek.

\subsubsection{Mintagyüjtés}

A mintákat a BCE Gyümölcstermő Növények Tanszék soroksári kísérleti telepén megtalálható, valamint az Újfehértói Gyümölcstermesztési Kutató és Szaktanácsadó Nonprofit Közhasznú Kft. génbanki gyüjteményeiben gyüjtöttük. A vizsgálatba vont egyedek fajtaazonossága bizonyított, csupán néhány fajta (pl. 'Budai Domokos', 'Fertődi téli') fajtaazonosságának tisztázása érdekében további termőhelyekröl (NÉBIH Növényfajta kísérleti Állomás pölöskei telepe, egy törökbálinti árugyümölcsös, egy faddi magángyüjtemény) is begyüjtöttünk mintákat. A mintavételezés során lehetőség szerint fiatal, 1-2 cm hosszú, még összesodrott leveleket gyüjtöttünk tavasszal, kora nyáron. A mintákat hütve szállítottuk, és a DNS-izolálás megkezdéséig -20 ${ }^{\circ} \mathrm{C}$-on tároltuk. Néhány esetben téli végi mintavételre nyílt lehetőség, amikor is a rügyeket használtuk fel a DNS kinyeréséhez.

\subsubsection{DNS-kivonás}

A genomi DNS-t a friss vagy fagyasztott fiatal levelekből vagy rügyekből DNeasy Plant Mini Kit (Qiagen) használatával, a gyártó leírása alapján vontuk ki. A DNS minőségét 1 \%-os agaróz gélen futtatva ellenőriztük. 


\subsubsection{PCR}

A DNS-szakaszok felszaporítása Applied Biosystems (Foster City, USA) Thermal Cycler 2720 típusú PCR készülékben történt $25 \mu$ végtérfogattal, DreamTaq ${ }^{\mathrm{TM}}$ Green PCR Master Mix (2X) kit (Fermentas) (összetétel: DreamTaq DNA Polymerase, 2x DreamTaq Green buffer, dNTP, $4 \mathrm{mM} \mathrm{MgCl}_{2}$ ) használatával (․ táblázat).

4. táblázat. A gyártó által javasolt és a PCR-reakció során alkalmazott összetevők

\begin{tabular}{lcc}
\hline & Javasolt mennyiség & Használt mennyiség \\
\hline DreamTaq Green PCR Master Mix (2X) & $25 \mu \mathrm{l}$ & $12,5 \mu \mathrm{l}$ \\
Forward primer & $0.1-1.0 \mu \mathrm{M}$ & $0,2 \mu \mathrm{M}$ \\
Reverse primer & $0.1-1.0 \mu \mathrm{M}$ & $0,2 \mu \mathrm{M}$ \\
Templát DNS & $10 \mathrm{pg}-1 \mu \mathrm{g}$ & $\sim 25 \mathrm{ng}$ \\
Steril desztillált víz & $50 \mu \mathrm{l}$-re kiegészítve & $25 \mu \mathrm{l}$-re kiegészítve \\
\hline Végtérfogat & $50 \mu \mathrm{l}$ & $25 \mu \mathrm{l}$ \\
\hline
\end{tabular}

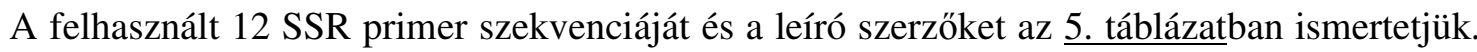
A használt primerpárok közül három (CH02c09, CH02c11, CH02d08) a Laurens et al. (2004) és Maggioni et al. (2004) által leírt, míg öt (CH01f02, CH01h01, CH02c09, CH02c11, CH02d08) az ECPGR (Xuan et al. 2010) által SSR vizsgálatokhoz javasolt markerkörben is megtalálható. A primerpárok forward tagja fluoreszcens festékkel (JOE; FAM) volt jelölve. Az amplifikálás körülményeit Galli et al. (2005) által javasolt program szerint állítottuk be (6. táblázat).

\subsubsection{Fragmentum-analízis}

A PCR-termékeket előzetesen 1 \%-os agaróz gélen GR Safe (Lab Supply Mall) festéssel UV fényben teszteltük. A fluoreszcens festékkel (JOE; FAM) jelölt PRC termékből a különböző fragmentumok detektálását ABI Prism 3100 Genetic Analyzer (Applied Biosystems, Foster City, USA) szekvenáló készülékkel a Biomi Kft. (Gödöllő) készítette. A fragmentumok hosszúságának meghatározása, eredmények kiértékelése Genographer 1.6 software segítségével készült (Benham 2001). 
5. táblázat. A felhasznált SSR primerek jellemzői (*=ECPGR által kijelölt primer)

\begin{tabular}{|c|c|c|c|c|}
\hline Primer neve & $\begin{array}{l}\text { Szekvencia } \\
\quad\left(5^{\prime}-3^{\prime}\right)\end{array}$ & $\begin{array}{l}\text { Allélméret } \\
\text { tartomány }\end{array}$ & $\begin{array}{l}\text { Kapcsoltsági } \\
\text { csoport }\end{array}$ & Referencia \\
\hline $\begin{array}{l}\mathrm{CH} 01 \mathrm{f0} 2 \mathrm{~F} * \\
\mathrm{CH} 01 \mathrm{f0} 2 \mathrm{R}\end{array}$ & $\begin{array}{l}\text { JOE-ACCACATTAGAGCAGTTGAGG } \\
\text { CTGGTTTGTTTTCCTCCAGC }\end{array}$ & 174-206 & 12 & $\begin{array}{l}\text { Gianfranceschi } \\
\text { et al. } 1998\end{array}$ \\
\hline $\begin{array}{l}\text { CH01h01 F* } \\
\text { CH01h01 R }\end{array}$ & $\begin{array}{l}\text { JOE-GAAAGACTTGCAGTGGGAGC } \\
\text { GGAGTGGGTTTGAGAAGGTT }\end{array}$ & $114-134$ & 17 & $\begin{array}{l}\text { Gianfranceschi } \\
\text { et al. } 1998\end{array}$ \\
\hline $\begin{array}{l}\mathrm{CH} 02 \mathrm{c} 02 \mathrm{a} \mathrm{F} \\
\mathrm{CH} 02 \mathrm{c} 02 \mathrm{a} \mathrm{R}\end{array}$ & $\begin{array}{l}\text { JOE-CTTCAAGTTCAGCATCAAGACAA } \\
\text { TAGGGCACACTTGCTGGTC }\end{array}$ & $129-176$ & 2 & $\begin{array}{l}\text { Liebhard et al. } \\
2002\end{array}$ \\
\hline $\begin{array}{l}\mathrm{CH} 02 \mathrm{c09} \mathrm{F} * \\
\mathrm{CH} 02 \mathrm{c09} \mathrm{R}\end{array}$ & $\begin{array}{l}\text { FAM-TTATGTACCAACTTTGCTAACCTC } \\
\text { AGAAGCAGCAGAGGAGGATG }\end{array}$ & $233-257$ & 15 & $\begin{array}{l}\text { Liebhard et al. } \\
2002\end{array}$ \\
\hline $\begin{array}{l}\text { CH05e03 F } \\
\text { CH05e03 R }\end{array}$ & $\begin{array}{l}\text { FAM-CGAATATTTTCACTCTGACTGGG } \\
\text { CAAGTTGTTGTACTGCTCCGAC }\end{array}$ & $158-190$ & 2 & $\begin{array}{l}\text { Liebhard et al. } \\
2002\end{array}$ \\
\hline $\begin{array}{l}\mathrm{CH} 04 \mathrm{e} 03 \mathrm{~F} \\
\mathrm{CH} 04 \mathrm{e} 03 \mathrm{R}\end{array}$ & $\begin{array}{l}\text { FAM-TTGAAGATGTTTGGCTGTGC } \\
\text { TGCATGTCTGTCTCCTCCAT }\end{array}$ & $179-222$ & 5 & $\begin{array}{l}\text { Liebhard et al. } \\
2002\end{array}$ \\
\hline $\begin{array}{l}\text { CH05d11 F } \\
\text { CH05d11 R }\end{array}$ & $\begin{array}{l}\text { JOE-CACAACCTGATATCCGGGAC } \\
\text { GAGAAGGTCGTACATTCCTCAA }\end{array}$ & $171-211$ & 12 & $\begin{array}{l}\text { Liebhard et al. } \\
2002\end{array}$ \\
\hline $\begin{array}{l}\text { CH03g07 F } \\
\text { CH03g07 R }\end{array}$ & $\begin{array}{l}\text { FAM-AATAAGCATTCAAAGCAATCCG } \\
\text { TTTTTCCAAATCGAGTTTCGTT }\end{array}$ & 119-181 & 3 & $\begin{array}{l}\text { Liebhard et al. } \\
2002\end{array}$ \\
\hline $\begin{array}{l}\mathrm{CH} 02 \mathrm{c} 11 \mathrm{~F} * \\
\mathrm{CH} 02 \mathrm{c} 11 \mathrm{R}\end{array}$ & $\begin{array}{l}\text { FAM-TGAAGGCAATCACTCTGTGC } \\
\text { TTCCGAGAATCCTCTTCGAC }\end{array}$ & 219-239 & 10 & $\begin{array}{l}\text { Liebhard et al. } \\
2002\end{array}$ \\
\hline $\begin{array}{l}\mathrm{CH} 02 \mathrm{~d} 08 \mathrm{~F} * \\
\mathrm{CH} 02 \mathrm{~d} 08 \mathrm{R}\end{array}$ & $\begin{array}{l}\text { FAM-TCCAAAATGGCGTACCTCTC } \\
\text { GCAGACACTCACTCACTATCTCTC }\end{array}$ & $210-254$ & 11 & $\begin{array}{c}\text { Liebhard et al. } \\
2002\end{array}$ \\
\hline $\begin{array}{l}\mathrm{CH} 03 \mathrm{a} 02 \mathrm{~F} \\
\mathrm{CH} 03 \mathrm{a} 02 \mathrm{R}\end{array}$ & $\begin{array}{l}\text { FAM-TTGTGGACGTTCTGTGTTGG } \\
\text { CAAGTTCAACAGCTCAAGATGA }\end{array}$ & $124-184$ & 14 & $\begin{array}{l}\text { Liebhard et al. } \\
2002\end{array}$ \\
\hline $\begin{array}{l}\mathrm{CH} 05 \mathrm{c0} 4 \mathrm{~F} \\
\mathrm{CH} 05 \mathrm{c0} 4 \mathrm{R}\end{array}$ & $\begin{array}{l}\text { FAM-CCTTCGTTATCTTCCTTGCATT } \\
\text { GAGCTTAAGAATAAGAGAAGGGG }\end{array}$ & $186-258$ & 13 & $\begin{array}{l}\text { Liebhard et al. } \\
\quad 2002\end{array}$ \\
\hline
\end{tabular}

6. táblázat. A PCR reakció során alkalmazott program (Galli et al. 2005)

\begin{tabular}{llll}
\hline Ciklusszám & Folyamat & Hömérséklet & Időtartam \\
\hline \multirow{3}{*}{$35 \mathrm{x}$} & Elödenaturáció & $94^{\circ} \mathrm{C}$ & 2 perc \\
& Denaturáció & $94^{\circ} \mathrm{C}$ & 20 másodperc \\
& Primerek bekötése & $56^{\circ} \mathrm{C}$ & 30 másodperc \\
& Lánchosszabbítás & $72^{\circ} \mathrm{C}$ & 1 perc \\
\hline & Utóbefoltozás & $72^{\circ} \mathrm{C}$ & 5 perc \\
\hline
\end{tabular}

\subsection{Statisztikai elemzés}

\subsubsection{A morfológiai adatok statisztikai kiértékelése}

Az UPOV számkulcsos jellemzése lehetőséget ad arra, hogy statisztikai elemzést végezzünk az adatsorral. Az egyes tulajdonságokon belüli kifejeződési fokozatok százalékban megadott gyakoriságát a PASW 18.0 statisztikai programcsomaggal elemeztük. 
Az UPOV akkor tekint két fajtát különbözőnek, ha legalább egy tulajdonságban világos eltérést mutatnak. Mégpedig úgy, hogy a kvalitatív (QL) és pszeudo-kvalitatív (PQ) tulajdonságoknál egy fokozat eltérés, míg a kvantitatív (QN) tulajdonságoknál két fokozat eltérés jelenti az egyértelmü különbséget.

A statisztikai kiértékelés során a fajták számkódos jellemzéséből kiindulva Excelben egy mátrixot készítettünk, amelynél figyelembe vettuik a tulajdonságok fent bemutatott jellegét. A fajták páronkénti összehasonlításakor 0 értéket kapott az a kifejeződési fokozat, ahol nem volt egy (QL és PQ), ill. két (QN) fokozat eltérés, és 1 értéket kapott, ahol ez az eltérés teljesült. Ezután a 0-1 kódolás értékeit fajtánként összeadtuk, és így kaptuk meg a hasonlósági mátrixot, amit a további statisztikai elemzésekhez használtunk fel.

A hierarchikus klaszteranalízist, ill. a dendrogramot Ward-féle módszerrel, a fent bemutatott mátrix alapján az R-programban (R Development Core Team 2008) készítettük el.

\subsubsection{Az SSR fragmentumhosszok statisztikai kiértékelése}

A lókuszok jellemzését az Identity 1.0 programmal (Wagner és Sefc 1999) készítettük el kizárólag a diploid fajták adatai alapján, mert ez a program a triploidokat nem tudja kezelni.

A következő tulajdonságokat határoztuk meg:

- allélok száma lókuszonként;

- $\quad$ allélgyakoriság (p);

- várt heterozigótaság $\left(H_{\mathrm{e}}=1-\Sigma \mathrm{p}_{\mathrm{i}}^{2}\right.$, ahol $\mathrm{p}_{\mathrm{i}}$ a vizsgált lókusz i-edik alléljának gyakorisága) (Nei 1973);

- megfigyelt heterozigótaság $\left(\mathrm{H}_{\mathrm{o}}\right)$ : a heterozigóta egyedek aránya a teljes egyedszámhoz képest a populációban;

- $\quad$ null allélok előfordulásának valószínüsége $\left(\mathrm{r}=\left(\mathrm{H}_{\mathrm{e}}-\mathrm{H}_{\mathrm{o}}\right) /\left(1+\mathrm{H}_{\mathrm{e}}\right)\right)$ (Brookfield 1996);

- azonos genotípus előfordulásának valószínüsége $\left(\mathrm{PI}=\Sigma \mathrm{p}_{\mathrm{i}}{ }^{4}+\Sigma \Sigma\left(2 \mathrm{p}_{\mathrm{i}} \mathrm{p}_{\mathrm{j}}\right)^{2}(\right.$ Paetkau et al. 1995).

A hierarchikus klaszteranalízishez a fragmentumokat tartalmazó adatsort bináris formába alakítottuk át, tehát minden egyes fragmentum jelenlétét 1 , míg hiányát 0 jelzi. A bináris adatokból a Jaccard-indexen alapuló genetikai távolság mátrix (Jaccard 1908) alapján dendrogramot szerkesztettünk a PAST program (Hammer et al. 2001) segítségével.

A morfológiai és molekuláris eredmények közti összefüggés vizsgálatát Mantelteszttel (Mantel és Valand 1970) végeztük a PASSaGE v2 programmal (Rosenberg és Anderson 2011). Ehhez a 4.5.1. fejezetben ismertetett UPOV adatokon alapuló, és a bináris SSR adatok Jaccard-indexén alapuló genetikai távolság mátrixokat használtuk fel. 


\section{EREDMÉNYEK}

\subsection{Fenológiai jellemzők}

\subsubsection{Virágzási idő}

2007. április elején a léghőmérséklet egyenletesen emelkedett (2. ábra), majd a hónap közepén bekövetkezett lehűlés és az azt követő lassú felmelegedés miatt a gyüjteményben a virágzás 20 napig tartott (․ táblázat). 2008-ban a gyors kivirágzást elhúzódó, lassú elvirágzás követett, amely a virágzás kezdetén és egy hét múlva, a fővirágzás idején bekövetkezett enyhe (kb. $\left.5{ }^{\circ} \mathrm{C}\right)$ lehüléseknek tudható be. Az öt vizsgálati év közül ebben az évben tapasztaltuk a leghosszabb, 26 napos virágzástartamot a fajtagyüjteményben. 2009-ben a tartósan $10{ }^{\circ} \mathrm{C}$ feletti napi középhőmérséklet gyors virágzást eredményezett. 2010. április első két dekádjában a korábbi évek adott időszakához képest $2-3{ }^{\circ} \mathrm{C}-\mathrm{kal}$ alacsonyabb hőmérsékletet mértek, amelynek következtében a virágzás átlagosan 7-8 nappal később kezdődött, mint az előző három évben. Hasonlót tapasztaltunk 2011-ben is: az április 13-15. közötti jelentős hőmérséklet csökkenés miatt 5-6 nappal később kezdődött, viszont gyorsan lezajlott a virágzás.

7. táblázat. A virágzás időtartama (Soroksár, 2007-2011)

\begin{tabular}{llccc}
\hline \multirow{2}{*}{ Vizsgálati év } & \multicolumn{2}{c}{ Teljes gyüjtemény virágzási időtartama } & \multicolumn{2}{c}{ Fajták virágzási időtartama } \\
\cline { 2 - 5 } & virágzási időszak & virágzás tartama & minimum & maximum \\
\hline 2007 & április 10-30. & 20 nap & 4 nap & 15 nap \\
2008 & április 14-május 10. & 26 nap & 4 nap & 15 nap \\
2009 & április 14-28. & 14 nap & 4 nap & 12 nap \\
2010 & április 21-május 5. & 14 nap & 4 nap & 10 nap \\
2011 & április 18-május 3. & 15 nap & 3 nap & 8 nap \\
\hline
\end{tabular}

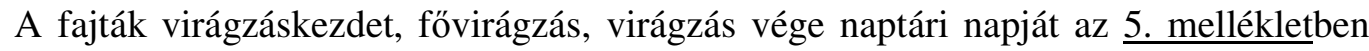
mutatjuk be. A virágzási időtartam szempontjából említést érdemel az elhúzódó virágzású 'Zöld batul' és 'Beregi sóvári’ 2. genotípusa, amelyeknél igen hosszú (10-15 nap) virágzási időtartamot tapasztaltunk, míg a gyüjteményben a virágzás átlagosan 7-8 napig tartott (ㅁ․ táblázat). Az egyes vizsgálati években tapasztalt igen rövid, 4-6 napos virágzási időtartamok elsősorban a gyenge-közepes virágberakódottságból adódnak. Ez fajtabélyegre utal abban az esetben, ha minden évben tapasztalható, mint azt a 'Cigány alma', 'Gegesi piros', 'Gyógyi piros', 'Ízletes zöld’ és a ‘Tordai alma’ példája mutatja. 
8. táblázat. A vizsgált fajták virágzási időtartama (nap) (Soroksár, 2007-2011)

\begin{tabular}{|c|c|c|c|c|c|c|c|c|c|c|c|}
\hline Vizsgált fajta & 2007 & 2008 & 2009 & 2010 & 2011 & Vizsgált fajta & 2007 & 2008 & 2009 & 2010 & 2011 \\
\hline Bánffy Pál & & 8 & 8 & 9 & 5 & Lóci cirmos alma & 7 & 6 & 4 & 7 & \\
\hline Batul 1 & & 7 & 6 & 10 & 5 & Lóci édes almája & & 9 & 4 & 7 & 8 \\
\hline Batul 2 & 7 & 11 & 8 & 7 & 8 & Londoni pepin & 11 & 9 & 12 & 9 & 8 \\
\hline Batul 3 & 6 & 7 & 8 & 10 & 8 & Marosszéki piros & & 7 & 8 & 5 & 6 \\
\hline Baumann renet & & 11 & 8 & 10 & 8 & Masánszki & & 9 & 12 & 7 & 8 \\
\hline Beregi sóvári 1 & & 13 & 8 & 7 & 6 & Máté Dénes & & 8 & 4 & 10 & 8 \\
\hline Beregi sóvári 2 & 15 & 11 & 8 & 10 & 8 & Mosolygós batul & & 7 & 8 & 7 & 5 \\
\hline Bőrkormos renet & 7 & 11 & 8 & 10 & 6 & Nemes sóvári & & 6 & 8 & & 6 \\
\hline Budai Domokos & & & 8 & & 6 & Nemes szercsika & & 6 & 8 & 7 & 5 \\
\hline Budai Ignác & & 10 & 4 & 7 & & Ontario & & 8 & 8 & 10 & 8 \\
\hline Cigány alma & 4 & 6 & 8 & 5 & 6 & Orbai alma & 6 & 7 & 6 & & 7 \\
\hline Cserepánya & & 14 & 8 & 10 & 6 & Sándor cár & & 9 & 8 & 9 & 8 \\
\hline Csíkos óriás halasi & & 11 & 4 & 7 & & Sárga szépvirágú & 6 & 13 & 8 & 5 & 5 \\
\hline Dániel féle renet & 8 & 8 & 8 & 9 & 8 & Sikulai & 11 & 6 & 8 & 7 & 6 \\
\hline Daru sóvári & & 10 & & 9 & 6 & Simonffy piros & 11 & 11 & & 10 & \\
\hline Édes escoar & 6 & 7 & 10 & 5 & 8 & Sóvári nobil & & 7 & & 9 & \\
\hline Entz Rozmaring & & 8 & 8 & 7 & 3 & Szabadkai szercsika & & & 8 & 7 & 8 \\
\hline Fekete tányéralma & & 7 & 4 & 7 & & Szászpap alma & & 7 & 8 & 7 & 5 \\
\hline Gegesi piros & & 4 & 8 & 4 & 6 & Széchenyi renet & 8 & 7 & 10 & 5 & 5 \\
\hline Gomba Károly & & 7 & 4 & 7 & 3 & Tartós Gusztáv & 7 & 12 & 12 & 9 & 8 \\
\hline Gyógyi piros & & 6 & 4 & 7 & 5 & Tordai alma & & 6 & 6 & 7 & 5 \\
\hline Harang alma & & 7 & 8 & 9 & & Tordai piros kálvil & & & & 7 & 6 \\
\hline Herceg Batthyány & 5 & 11 & 8 & 7 & 5 & Tükör alma & & 7 & & 10 & \\
\hline Hosszúfalusi & 8 & 8 & 8 & 5 & 5 & Vajki alma & 6 & 9 & 8 & 7 & 8 \\
\hline Ízletes zöld & & 6 & 4 & 5 & 8 & Vilmos renet & 7 & 7 & 8 & 10 & 8 \\
\hline Jászvadóka & 8 & 7 & 6 & 5 & 4 & Zöld batul & 10 & 15 & & & 5 \\
\hline Kanadai renet 1 & 11 & 6 & & 5 & 5 & & & & & & \\
\hline Kanadai renet 2 & & 6 & 8 & 5 & 8 & Kontroll: & & & & & \\
\hline Kanadai renet 3 & & 9 & 8 & 7 & 5 & Reglindis & 8 & 10 & 5 & 6 & \\
\hline Királyi renet & 11 & 8 & 8 & & 8 & Florina & 7 & 7 & 6 & 7 & 7 \\
\hline Kisasszony & & 8 & 12 & 4 & 8 & Rewena & & 3 & 6 & 7 & 7 \\
\hline Átlag & & \multicolumn{2}{|c|}{2007} & \multicolumn{2}{|c|}{2008} & 2009 & \multicolumn{2}{|c|}{2011} & & & \\
\hline & & \multicolumn{2}{|c|}{8,2} & \multicolumn{2}{|c|}{8,2} & 7,5 & \multicolumn{2}{|c|}{6,5} & & & \\
\hline
\end{tabular}

A fajtatársításhoz indokolt a virágzási időcsoport megadása. Az ötéves felmérések alapján - a Bodor et al. (2008) által ajánlott referenciafajták figyelembevételével - öt virágzási időcsoportba soroltuk a fajtákat (9. táblázat). Az egyes csoporton belül a fajtákat nem rendeztük $\mathrm{ABC}$ sorrendbe, hanem meghagytuk a tényleges virágzási sorrendet. Feltüntettük a virágzás kezdete és fővirágzás szerinti sorrendet is, mert a különböző szakirodalmak nem egységesek abban a tekintetben, hogy a két jellemző közül melyiket javasolják figyelembe venni a fajtatársításnál. A 60 fajtán végzett megfigyeléseink alapján elmondható, hogy az igen korai és az igen kései virágzású fajták mind a virágzás kezdete, mind pedig a fővirágzás alapján azonos csoportba sorolhatók. A legjelentősebb eltérés a kétféle csoportosítási mód között a közepes és a kései virágzású fajták esetében tapasztalható. 
9. táblázat. A virágzás kezdete és a fővirágzás alapján kialakított virágzási időcsoportok (Soroksár, 2007-2011)

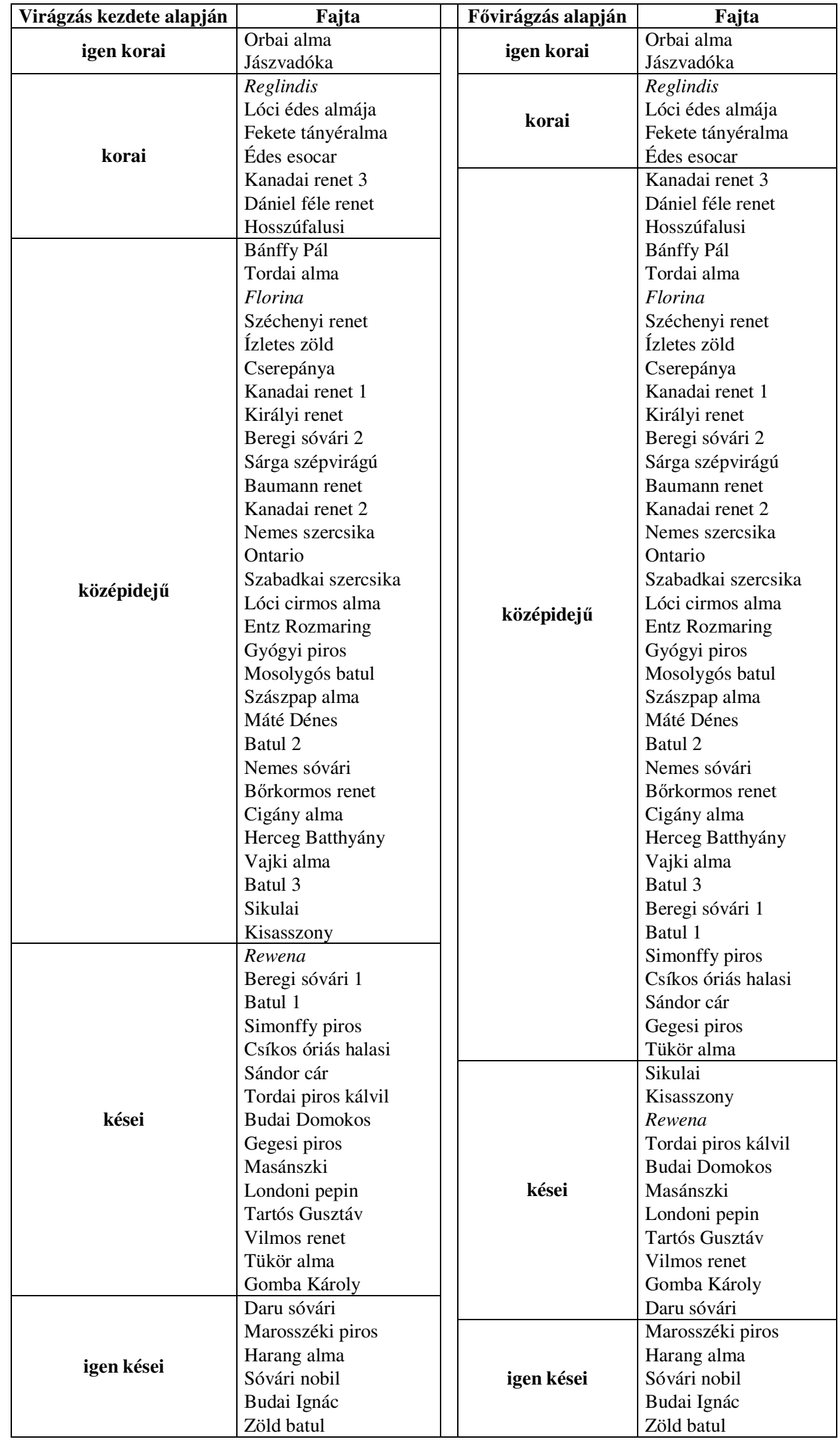


A legtöbb vizsgált fajta közepes vagy kései virágzási csoportba került. Igen korai virágzásúnak csak az 'Orbai alma’ és a 'Jászvadóka' bizonyult. A gyüjteményünk legkésőbb virágzó fajtái minden évben az igen kései virágzási időcsoportba sorolt 'Daru sóvári', 'Marosszéki piros', 'Harang alma', 'Sóvári nobil', 'Budai Ignác' és 'Zöld batul'. Ez utóbbi fajta a legtöbb évben akkor kezd el virágozni, amikor a gyüjtemény legtöbb fajtája már elvirágzott. Eddigi megfigyeléseink alapján az igen korai, korai és az igen kései virágzású fajták stabil virágzási idejünek tekinthetők, viszont a középidejü és a kései virágzású fajták többségénél további vizsgálati évek szükségesek a virágzási időcsoportba való pontos besoroláshoz.

Az UPOV irányelvei szerinti fajtajellemzést 60 fajtán végeztük. Ezek közül a részletes virágzásfenológiai vizsgálatokba 57 fajtát vontunk be. Az első vizsgálati években a 'Húsvéti rozmaring', 'Nyári fontos’ és 'Zöld sóvári’ fajták gyenge virágzási erélyt mutattak, csak 2011-ben kaptunk megfelelő mennyiségű virágot. A virágzási időcsoportba az egyéves vizsgálat alapján soroltuk be ezt a három fajtát, a teljes körü UPOV jellemzés érdekében, így az ezekre a fajtákra vonatkozó adatok is szerepelnek a virágzás kezdete szerinti kifejeződési kategóriák \%-os megoszlását bemutató táblázatban. Nagyon korai virágzási kezdetű fajta csak kettő volt a vizsgált fajták között. A fajták $10 \%$-a korai, 52 \%-a közepes, $25 \%$-a kései és $10 \%$-a nagyon késői virágzási időcsoportba került (10. táblázat).

10. táblázat. Fenológiához köthető tulajdonságok kifejeződési fokozatainak megoszlása a 60 vizsgált fajtán

\begin{tabular}{|c|c|c|c|c|c|}
\hline $\begin{array}{l}\text { TG/14/9 } \\
\text { sorszám }\end{array}$ & Tulajdonság & Kifejeződési fokozat & Kód & $\begin{array}{l}\text { Fajták } \\
\text { száma }\end{array}$ & $\%$ \\
\hline \multirow[t]{5}{*}{55.} & Virágzás kezdetének időpontja & nagyon korai & 1 & 2 & 3,3 \\
\hline & & korai & 3 & 6 & 10 \\
\hline & & közepes & 5 & 31 & 51,7 \\
\hline & & kései & 7 & 15 & 25 \\
\hline & & nagyon kései & 9 & 6 & 10 \\
\hline \multirow[t]{5}{*}{56.} & Szedési érettség időpontja & nagyon korai & 1 & 0 & 0 \\
\hline & & korai & 3 & 8 & 13,3 \\
\hline & & közepes & 5 & 11 & 18,3 \\
\hline & & kései & 7 & 38 & 63,3 \\
\hline & & nagyon kései & 9 & 3 & 5 \\
\hline \multirow[t]{9}{*}{57.} & Fogyasztási érettség időpontja & nagyon korai & 1 & 0 & 0 \\
\hline & & nagyon korai - korai & 2 & 4 & 6,7 \\
\hline & & korai & 3 & 1 & 1,7 \\
\hline & & korai - közepes & 4 & 8 & 13,3 \\
\hline & & közepes & 5 & 9 & 15 \\
\hline & & közepes - kései & 6 & 6 & 10 \\
\hline & & kései & 7 & 13 & 21,7 \\
\hline & & kései - nagyon kései & 8 & 12 & 20 \\
\hline & & nagyon kései & 9 & 7 & 11,7 \\
\hline
\end{tabular}




\subsection{2. Érési idő}

Fenológiához kapcsolódó gyümölcstulajdonságok a szedési érettség és a fogyasztási érettség időpontja. Nagyon korai érésủ fajta nem található a vizsgált fajták között (10. táblázat). 8 fajta ('Hosszúfalusi’, 'Jászvadóka', 'Nyári fontos’, 'Orbai alma', 'Sándor cár', 'Tordai alma', 'Vajki alma' és a 'Zöld batul') korai (augusztus eleje-közepe) szedési érettségü. 11 fajtát közepes (augusztus vége-szeptember eleje), 38 fajtát kései (szeptember közepe-vége) és 3 fajtát ('Masánszki', 'Ontario', 'Zöld sóvári') nagyon kései (október eleje-közepe) szedési idő jellemez. A fogyasztási érettséget tekintve a korai szedési idejü fajták nagyon korai-korai csoportba kerültek, míg a fajták többsége közepes vagy kései fogyasztási idővel jellemezhető, és csupán $12 \%$ nagyon kései fogyasztási érettségü.

\subsection{Növekedési és terméshozási sajátosságok}

Lomb nélküli állapotban vizsgáltuk 60 fajtán a fa növekedési és terméshozási jellemzőit. A összes vizsgált fajta elágazódó típusú fával rendelkezik (11. táblázat). Nagyon gyenge növekedési erélyü és oszlopos típusú fajtát nem találtunk a gyüjteményben. A fajták $55 \%$-a közepes, $25 \%$-a gyenge, és $20 \%$-a erős növekedéssel bír. Az elágazódó fajtákat habitus szerint négy csoportba lehet sorolni az UPOV útmutatója szerint. Csüngő habitusú fajtát nem találtunk, míg a feltörő habitus is csak két fajtánál fordult elő. A fajták egyötöde lehajló, míg a $77 \%$-a elterülő habitust mutatott. A leggyakoribb - és gyakorlati szempontból legkedvezőbb - terméshozási típus volt az, amikor a termőnyársakon és hosszú vesszőkön (70\%) is kaptunk termést. A fajták $30 \%$-a vagy csak nyársakon, vagy csak hosszú vesszőkön termett.

11. táblázat. Növekedési és terméshozási tulajdonságok kifejeződési fokozatainak megoszlása a 60 fajtán

\begin{tabular}{|c|c|c|c|c|c|}
\hline $\begin{array}{l}\text { TG/14/9 } \\
\text { sorszám }\end{array}$ & Tulajdonság & Kifejeződési fokozat & Kód & $\begin{array}{c}\text { Fajták } \\
\text { száma }\end{array}$ & $\%$ \\
\hline \multirow[t]{4}{*}{1.} & Fa: növekedési erély & nagyon gyenge & 1 & 0 & 0 \\
\hline & & gyenge & 3 & 15 & 25 \\
\hline & & közepes & 5 & 33 & 55 \\
\hline & & erös & 7 & 12 & 20 \\
\hline \multirow[t]{2}{*}{2.} & Fa: típus & oszlopos & 1 & 0 & 0 \\
\hline & & elágazó & 2 & 60 & 100 \\
\hline \multirow[t]{4}{*}{3.} & Csak elágazó típusú fajták: & feltörő & 1 & 2 & 3,3 \\
\hline & Fa: habitus & elterülő & 2 & 46 & 76,7 \\
\hline & & lehajló & 3 & 12 & 20 \\
\hline & & csüngő & 4 & 0 & 0 \\
\hline \multirow[t]{3}{*}{4.} & Fa: terméshozás típusa & csak termőnyársakon & 1 & 10 & 16,7 \\
\hline & & termőnyársakon és hosszú vesszőkön & 2 & 42 & 70 \\
\hline & & csak hosszú vesszőkön & 3 & 8 & 13,3 \\
\hline
\end{tabular}




\subsection{Morfológiai és egyéb küllemi tulajdonságok}

A mért paraméterek (virágátmérő, levéllemez hosszúság, szélesség, levélnyél hosszúság, gyümölcsmagasság, -átmérő) egyes években tapasztalt átlag-, minimum- és maximumértékeit táblázatos formában összesítve a $\underline{6}$. mellékletben mutatjuk be.

\subsubsection{A vessző jellemzői}

A vessző kvantitatív tulajdonságait szubjektív megfigyelés alapján soroltuk kifejeződési fokozatokba. Az öt vizsgált vessző tulajdonság mindegyik kategóriájába tudtunk besorolni fajtákat (kivétel a nagyon vastag vessző kategória). A fajták többsége közepes vastagságú (53\%), $25 \%$-uk vékony, és $22 \%$-uk vastag vesszővel rendelkezik (12. táblázat). A vessző ízköz hosszúsága többnyire közepes (40 \%) volt, de jelentős arányban találtunk rövid (32\%) és hosszú (27 \%) ízközü fajtát is.

A vessző napos oldalán megfigyelt színe alapján a legritkábban a sötétbarna (7 \%) szín fordult elő, míg a többi kifejeződési fokozat (zöldes-, pirosas-, világos- és középbarna) eloszlása arányos (20-28\%) volt. A vessző felső végén megjelenő szőrözöttség csak ritkán volt nagyon gyenge ( $8 \%$ ), gyenge (15\%) vagy nagyon erős (13\%), a fajták 60 \%-a közepes vagy erős szőrözöttséggel rendelkezett. A sok paraszemölccsel rendelkező fajták (53\%) voltak többségben.

12. táblázat. Vessző tulajdonságok kifejeződési fokozatainak megoszlása a 60 fajtán

\begin{tabular}{|c|c|c|c|c|c|}
\hline $\begin{array}{l}\text { TG/14/9 } \\
\text { sorszám } \\
\end{array}$ & Tulajdonság & Kifejeződési fokozat & Kód & $\begin{array}{l}\text { Fajták } \\
\text { száma }\end{array}$ & $\%$ \\
\hline \multirow[t]{4}{*}{5.} & Vessző: vastagság & vékony & 3 & 15 & 25 \\
\hline & & közepes & 5 & 32 & 53,3 \\
\hline & & vastag & 7 & 13 & 21,7 \\
\hline & & nagyon vastag & 9 & 0 & 0 \\
\hline \multirow[t]{4}{*}{6.} & Vessző: ízköz hosszúsága & nagyon rövid & 1 & 1 & 1,7 \\
\hline & & rövid & 3 & 19 & 31,7 \\
\hline & & közepes & 5 & 24 & 40 \\
\hline & & hosszú & 7 & 16 & 26,7 \\
\hline \multirow[t]{5}{*}{7.} & Vessző: színe a napos oldalon & zöldesbarna & 1 & 14 & 23,3 \\
\hline & & pirosasbarna & 2 & 12 & 20 \\
\hline & & világosbarna & 3 & 17 & 28,3 \\
\hline & & középbarna & 4 & 13 & 21,7 \\
\hline & & sötétbarna & 5 & 4 & 6,7 \\
\hline \multirow[t]{5}{*}{8.} & Vessző: szőrözöttség (a vessző & nincs vagy nagyon gyenge & 1 & 5 & 8,3 \\
\hline & felső felén) & gyenge & 3 & 9 & 15 \\
\hline & & közepes & 5 & 18 & 30 \\
\hline & & erös & 7 & 20 & 33,3 \\
\hline & & nagyon erős & 9 & 8 & 13,3 \\
\hline \multirow[t]{3}{*}{9.} & Vessző: paraszemölcsök száma & kevés & 3 & 17 & 28,3 \\
\hline & & közepes & 5 & 11 & 18,3 \\
\hline & & sok & 7 & 32 & 53,3 \\
\hline
\end{tabular}




\subsubsection{Hajtás és levél jellemzői}

\subsubsection{Levéllemez adatai}

2007-ben 54, 2008-ban pedig 27 fajta levelét vontuk vizsgálatba. A mintaszám csökkentésének az az oka, hogy a pontos mérésen alapuló kifejeződési fokozatba sorolás sok adatot eredményez, de rendkívül munkaigényes. Ezért az első évben több fajtán végeztünk pontos méréseket, a további években pedig csak ellenőrzésképpen mértünk néhány fajtát, a többi fajta esetében, és a további évek során a kifejeződési fokozatba sorolás már csak megfigyelés alapján történt. 2007-ben a fajták átlagos levéllemez hosszúsága 69-99mm között volt, átlagban 86 mm (․ melléklet). Ebben az évben a fajták 2/3-ánál rövid (35\%) vagy közepes (40\%) levéllemez hosszúságot mértünk (3. ábra). Nagyon rövid és hosszú levéllemeze a fajták 10-10\%-ának volt. Az átlagos levéllemez szélesség 48-74 mm, átlagban 62 mm. A fajták $15 \%$-a keskeny, $48 \%$-a közepes és $37 \%$-a széles levéllemezzel rendelkezett (․ ábra). A levélnyél hosszúsága 16-33 mm között változott, az átlag $24 \mathrm{~mm}$. A vizsgált fajták 59 \%-a a közepes levélnyél hosszúság kategóriába volt besorolható (․ ábra).

2008-ban a levéllemez hosszúsága 68 és 106 mm közé esett (átlag 88 mm) (ㅁ․ melléklet). Ebben az évben a fajták $11 \%$-ánál nagyon rövid, $26 \%$-ánál rövid, 44 \%-ánál közepes és $22 \%$-ánál hosszú levéllemez hosszúságot mértünk (ㅁa ábra). Az átlagos levéllemez szélesség 48-72 mm, átlagban 60 mm volt. A fajták megoszlása: keskeny $33 \%$, közepes $41 \%$, széles $26 \%$ (7. ábra). A levélnyél hosszúságának tekintetében a vizsgált fajták $15 \%$-a rövid, $59 \%$-a közepes és $26 \%$-a hosszú kategóriába tartozott (ㅁábra).

A 2009-es, 'Batul' és 'Sóvári' fajtákra vonatkozó adatokat a 6. mellékletben táblázatos formában mutatjuk be. A levéllemez hosszúság, szélesség és a levélnyél hosszúság adatok átlagos értékei csak pár mm eltérést mutattak az előző években mértekhez képeset, tehát a fajták ugyanabba vagy legfeljebb a szomszédos kifejeződési fokozatba kerültek.

A három év kifejeződési fokozatai alapján készítettük el a fajták végleges kategóriába sorolását (13. táblázat) úgy, hogy a leggyakoribb kifejeződési fokozatot tekintettük a fajtára jellemzőnek.

A levéllemez hosszúsága szerint a fajták harmadát rövid (32\%), másik harmadát közepes $(38 \%)$ kategóriába tudtuk besorolni a több éves mért adatok alapján. A levéllemez szélességét tekintve a fajták nagyjából azonos arányban oszlottak meg a három kategória között. A levéllemez hosszúság/szélesség aránya csak kevés fajtánál volt nagy (13\%), ami igen megnyúlt alakú levélre utal. A fajták $38 \%$-a kicsi hosszúság/szélesség arányt mutatott, ami a gömbölydedhez közelítő levélalakra jellemző. 


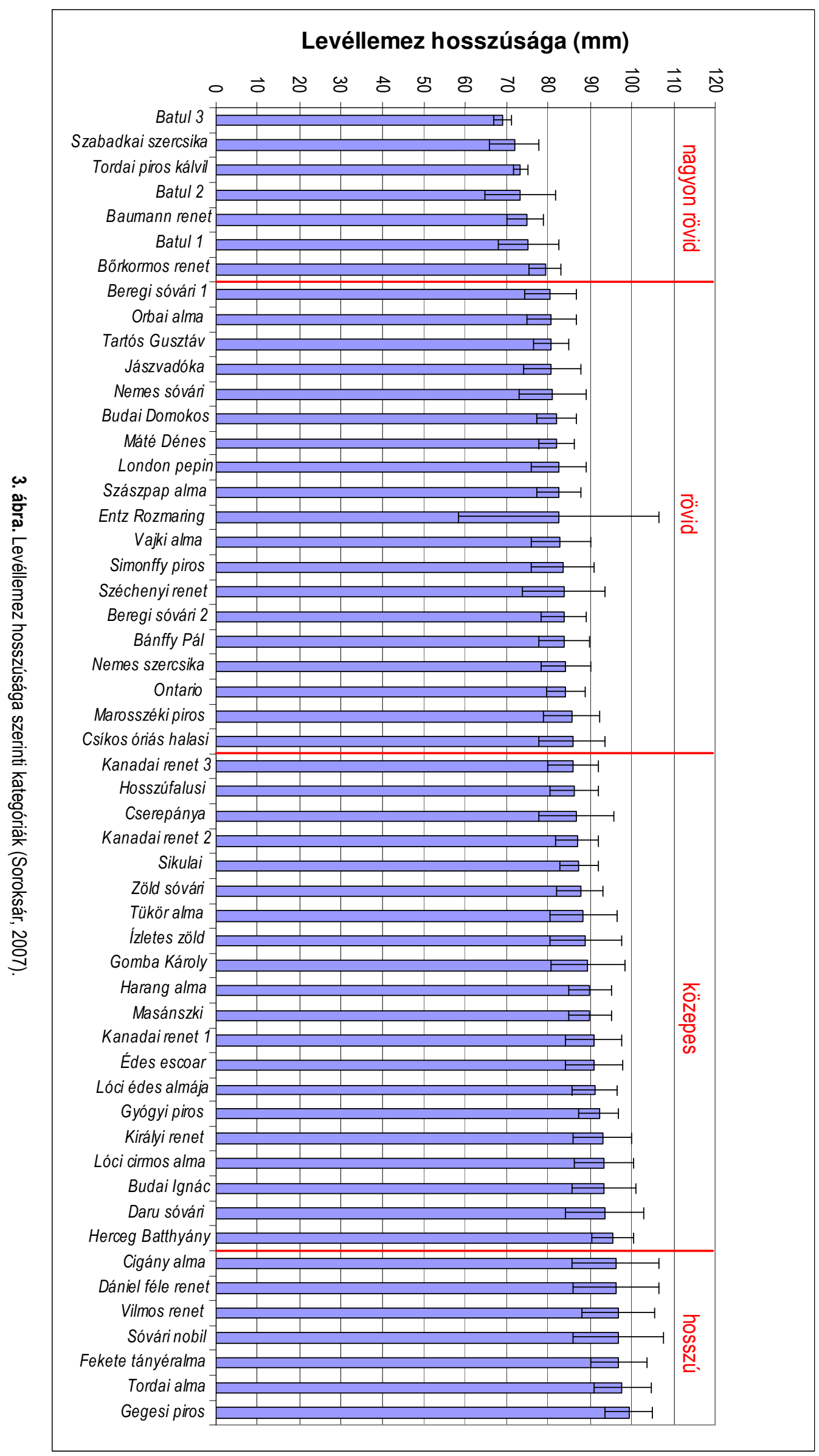




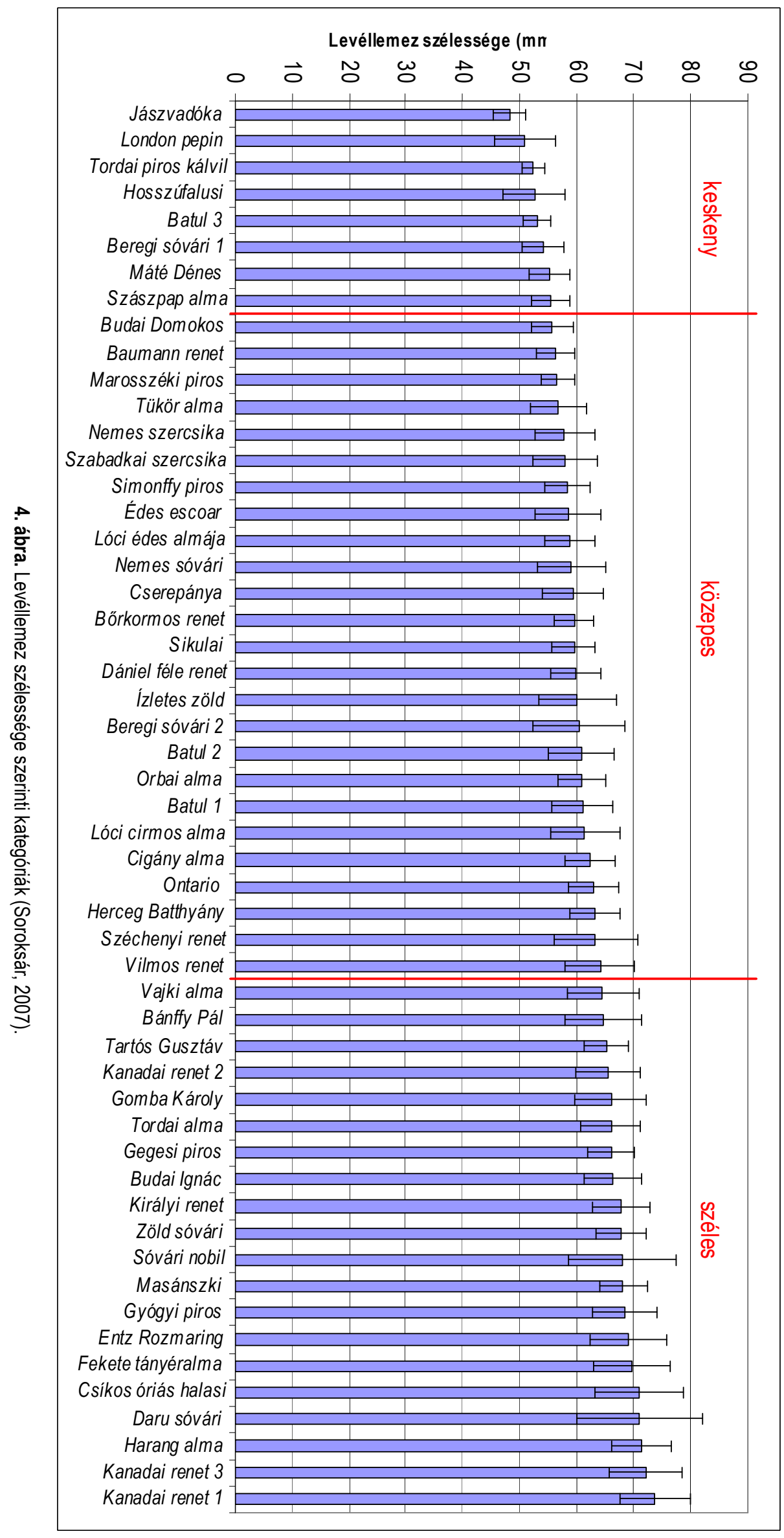




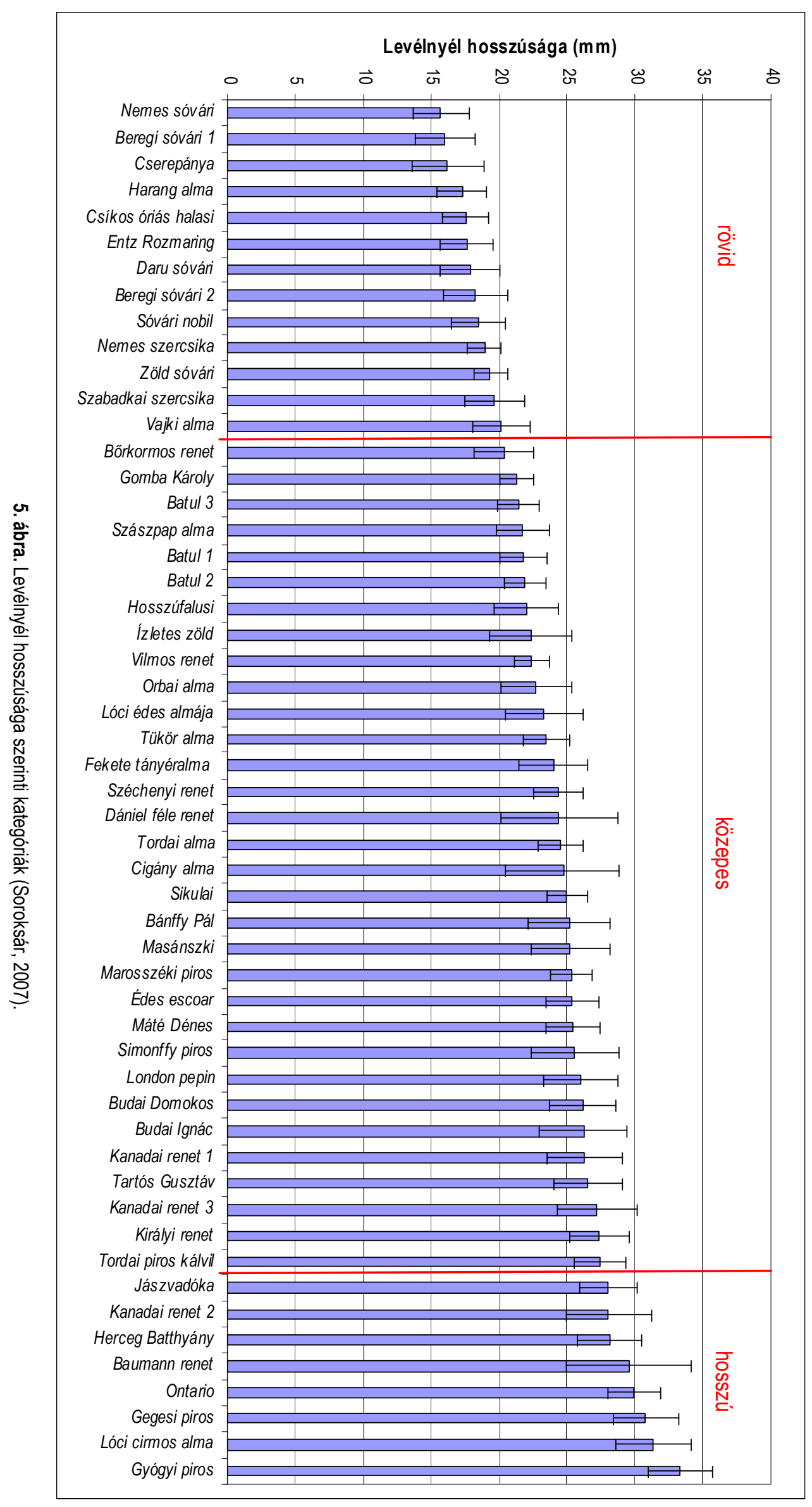



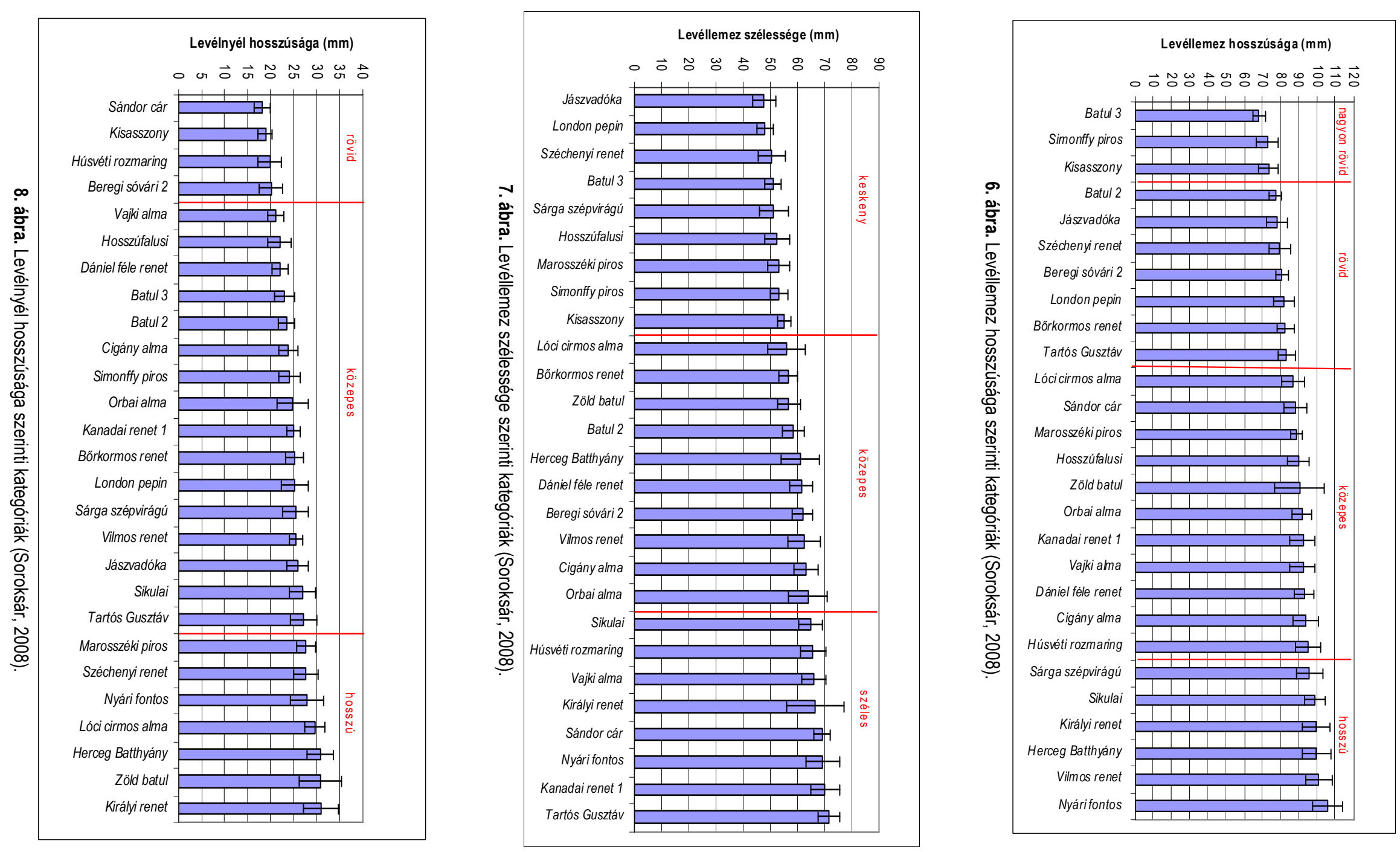
13. táblázat. A levéllemez és levélnyél tulajdonságok mérésen alapuló kifejeződési fokozatainak megoszlása

\begin{tabular}{|c|c|c|c|c|c|}
\hline $\begin{array}{l}\text { TG/14/9 } \\
\text { sorszám }\end{array}$ & Tulajdonság & Kifejeződési fokozat & Kód & $\begin{array}{l}\text { Fajták } \\
\text { száma }\end{array}$ & $\%$ \\
\hline \multirow[t]{4}{*}{11.} & Levéllemez: hosszúság & nagyon rövid & 1 & 8 & 13,3 \\
\hline & & rövid & 3 & 19 & 31,7 \\
\hline & & közepes & 5 & 23 & 38,3 \\
\hline & & hosszú & 7 & 10 & 16,7 \\
\hline \multirow[t]{3}{*}{12.} & Levéllemez: szélesség & keskeny & 3 & 16 & 26,7 \\
\hline & & közepes & 5 & 22 & 36,7 \\
\hline & & széles & 7 & 22 & 36,7 \\
\hline \multirow[t]{3}{*}{13.} & Levéllemez: hosszúság/szélesség & kicsi & 3 & 23 & 38,3 \\
\hline & aránya & közepes & 5 & 29 & 48,3 \\
\hline & & nagy & 7 & 8 & 13,3 \\
\hline \multirow[t]{3}{*}{17.} & Levélnyél: hosszúság & rövid & 3 & 16 & 26,7 \\
\hline & & közepes & 5 & 31 & 51,7 \\
\hline & & hosszú & 7 & 13 & 21,7 \\
\hline
\end{tabular}

A levélnyélen két tulajdonságot (levélnyél hossza és színeződése) vizsgáltunk. A mért adatok kifejeződési fokozatba konvertálása után azt tapasztaltuk, hogy a levélnyél hosszúsága a fajták felénél közepes (52\%), a többi fajta pedig kb. fele-fele arányban rendelkezik rövid (22\%) vagy hosszú (27\%) levélnyéllel.

\subsubsection{A hajtás és a levél egyéb jellemzői}

A hajtás és levél kvantitatív és kvalitatív tulajdonságainak kifejeződési kategóriák szerinti megoszlását a 14. táblázatban mutatjuk be. A levéllemez hajtáshoz viszonyított állása a fajták többségénél $(75 \%)$ kiálló, azaz a hajtás tengelyére merőleges, $25 \%$ pedig a felálló kategóriába sorolható. Csüngő helyzetü levelekkel egyetlen vizsgált fajta sem rendelkezik.

14. táblázat. A hajtás és levél tulajdonságok kifejeződési fokozatainak megoszlása a 60 fajtán

\begin{tabular}{|c|c|c|c|c|c|}
\hline $\begin{array}{l}\text { TG/14/9 } \\
\text { sorszám }\end{array}$ & Tulajdonság & Kifejeződési fokozat & Kód & $\begin{array}{l}\text { Fajták } \\
\text { száma }\end{array}$ & $\%$ \\
\hline \multirow[t]{3}{*}{10} & Levéllemez: hajtáshoz & felálló & 1 & 15 & 25 \\
\hline & viszonyított állása & kiálló & 2 & 45 & 75 \\
\hline & & csüngő & 3 & 0 & 0 \\
\hline \multirow[t]{3}{*}{14.} & Levéllemez: zöld szín intenzitása & világos & 3 & 6 & 10 \\
\hline & & közepes & 5 & 50 & 83,3 \\
\hline & & sötét & 7 & 4 & 6,7 \\
\hline \multirow[t]{5}{*}{15.} & Levéllemez: szélének & csipkés & 1 & 7 & 11,7 \\
\hline & bemetszése (felső fele) & kétszeresen csipkés & 2 & 2 & 3,3 \\
\hline & & fürészes 1. típusú & 3 & 22 & 36,7 \\
\hline & & fürészes 2. típusú & 4 & 17 & 28,3 \\
\hline & & kétszeresen fürészes & 5 & 12 & 20 \\
\hline \multirow[t]{3}{*}{16.} & Levéllemez: szőrözöttség a & nincs vagy nagyon gyenge & 1 & 11 & 18,3 \\
\hline & fonákán & közepes & 2 & 29 & 48,3 \\
\hline & & erös & 3 & 20 & 33,3 \\
\hline \multirow[t]{3}{*}{18.} & Levélnyél: antociános színeződés & kicsi & 3 & 28 & 46,7 \\
\hline & kiterjedése az alaptól & közepes & 5 & 23 & 38,3 \\
\hline & & nagy & 7 & 9 & 15 \\
\hline
\end{tabular}


A levéllemez szélének bemetszése leggyakrabban a fürészes valamelyik változata (1. típus (37\%), 2. típus (28\%), kétszeresen fürészes (20\%)) volt. Kétszeresen csipkézett levélszél a hatvan fajtából csak kettőnél (3\%) fordult elö, csipkézett levélszél pedig a fajták $12 \%$-át jellemezte.

A zöld szín intenzitása a legtöbb esetben közepes volt, világos- vagy sötétzöld színű levelet összesen csak 17 \%-ban tapasztaltunk. A fajták több mint 80 \%-ánál feltünő, közepes (48\%) vagy erős (33\%) a levélfonák szörözöttsége. Csak $18 \%$-ban tapasztaltuk a szőrözöttség hiányát vagy gyenge molyhosságot. A levélnyélen az antociános színeződés kiterjedése a leggyakrabban kicsi, alig észrevehető (47 \%) vagy közepes mértékü (38\%) volt.

\subsubsection{Virágjellemzők}

\subsubsection{A virágátmérő adatai}

8 fajtáról ('Édes escoar', 'Húsvéti rozmaring', 'Lóci édes almája', 'Masánszki', 'Nyári fontos', 'Sárga szépvirágú', 'Tordai piros kálvil’, 'Zöld sóvári’) a kevés virágzat miatt nem tudtunk mért adatot gyüjteni egyik évben sem.

2007-ben 29 fajta virágát tudtuk lemérni. Nagyon nagy eltérést találtunk a fajták virágátmérőjében, 36 és $61 \mathrm{~mm}$ közötti átlagértékeket kaptunk (․ melléklet). A kategóriák megoszlása a következő: a fajták 17 \%-a nagyon kicsi, 38 \%-a kicsi, 24 \%-a közepes, és a $21 \%$-a nagy virág átmérővel rendelkezett (9. ábra).

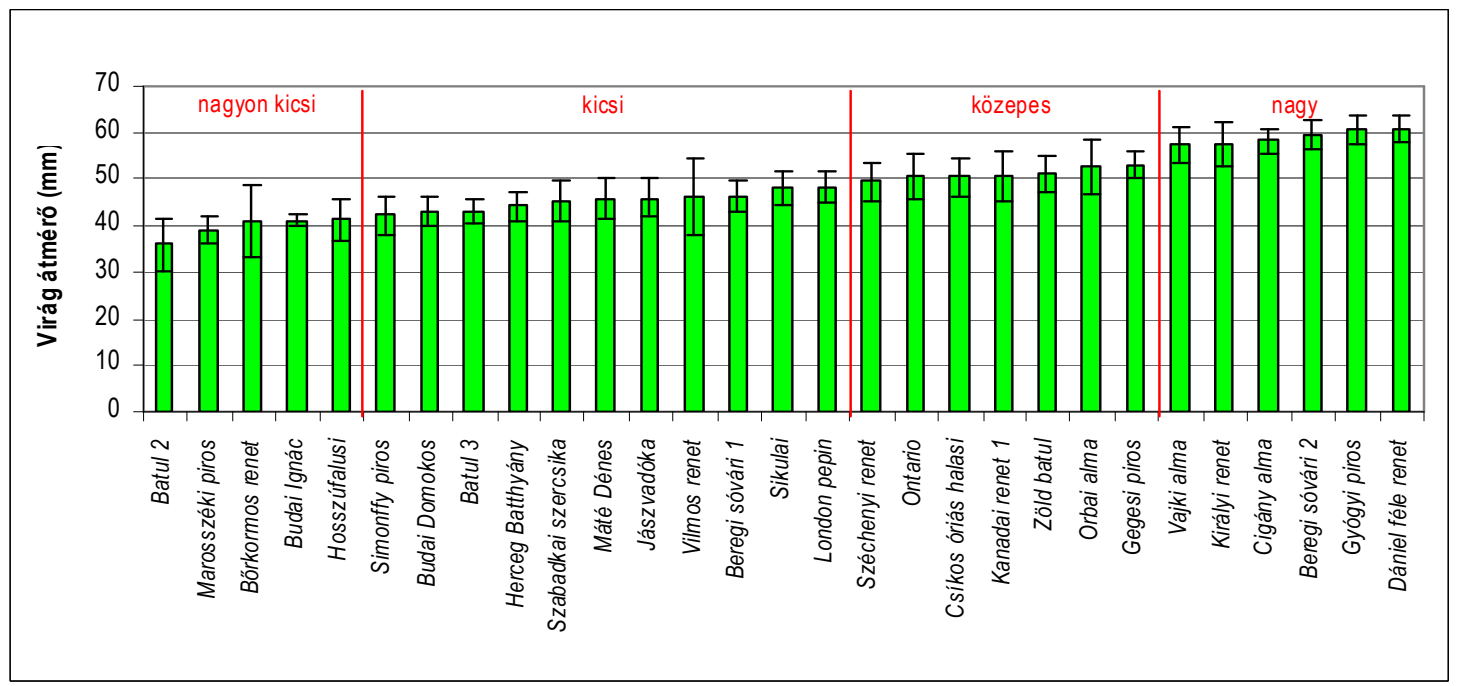

9. ábra. A virágok átmérője szerinti kategóriák (Soroksár, 2007).

2008-ban a 43 fajta mért virág átmérőinek átlagai az előző évhez hasonló értékeket mutattak, 40-66 mm közötti átlagokat kaptunk. A fajták többségét kicsi (42\%) vagy közepes (37 \%) kategóriába tudtuk besorolni, míg nagyon kicsi, ill. nagy virág átmérőt csak 3 fajtánál (7 \%), ill. 6 fajtánál (14\%) tapasztaltunk (10. ábra). 


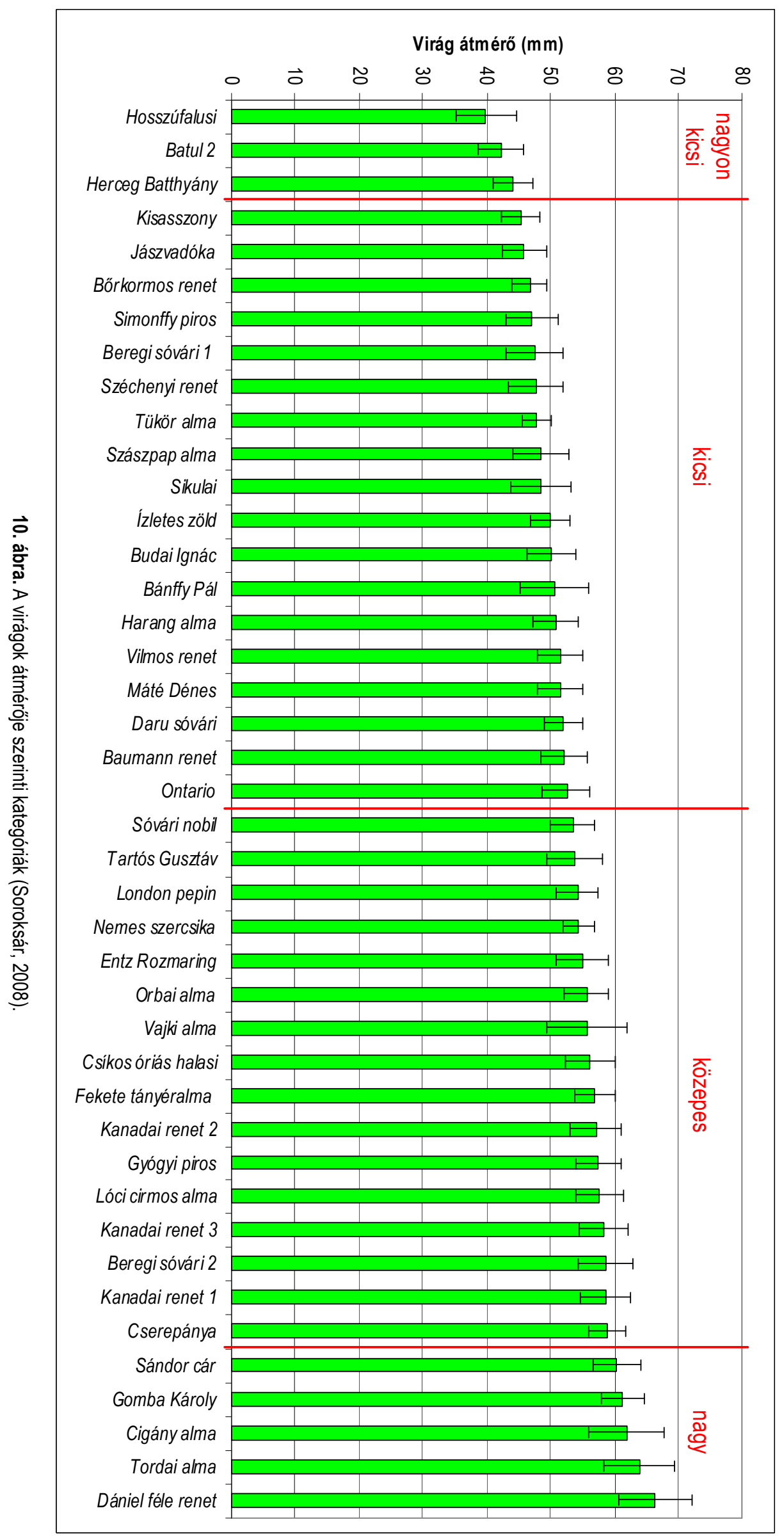


A 2009-ben csak a Batul és Sóvári fajtacsoportokba tartozó fajtákat, illetve változatokat mértük, míg a többi fajta esetében a kifejeződési fokozatba sorolás már csak megfigyelés alapján történt. A Batul és Sóvári fajták virága 37 és $50 \mathrm{~mm}$ közötti átlagos értékeket mutatott. A 2008-as év adataira felállított skála alapján virágaik a nagyon kicsi (56\%) és kicsi (44\%) csoportba sorolható (‥ melléklet).

A három 'Batul' alapfajta és a 'Mosolygós batul', továbbá a három 'Kanadai renet' minden vizsgálati évben hasonló adatokat mutatott. Viszont a 'Beregi sóvári' két szelekciójánál mindegyik évben jelentős méretbeli különbségeket tapasztaltunk.A több éves mért, és számkódos rendszerbe átalakított, valamint a kvalitatív tulajdonságok tényleges számkódos besorolása a leggyakrabban előforduló kifejeződési fokozat alapján történt. Ez alapján a fajták $10 \%$-a nagyon kicsi, 22 \%-a kicsi, míg a 2/3-a közepes (33 \%) vagy nagy (35\%) méretű virágokkal rendelkezik (15. táblázat).

15. táblázat. A virág tulajdonságok kifejeződési fokozatainak megoszlása a 60 fajtán

\begin{tabular}{cllccc}
\hline $\begin{array}{c}\text { TG/14/9 } \\
\text { sorszám }\end{array}$ & \multicolumn{1}{c}{ Tulajdonság } & \multicolumn{1}{c}{ Kifejezödési fokozat } & Kód & $\begin{array}{c}\text { Fajták } \\
\text { száma }\end{array}$ & $\%$ \\
\hline 19. & Virág: meghatározó szín & fehér & 1 & 0 & 0 \\
& szirombimbó állapotban & sárgás rózsaszín & 2 & 1 & 1,7 \\
& & világos rózsaszín & 3 & 16 & 26,7 \\
& & sötét rózsaszín & 4 & 35 & 58,3 \\
& & középpiros & 5 & 8 & 13,3 \\
& & sötétpiros & 6 & 0 & 0 \\
& & bíborszínű & 7 & 0 & 0 \\
\hline 20. & Virág: átmérő vízszintes & nagyon kicsi & 1 & 6 & 10 \\
& helyzetbe nyomott & kicsi & 3 & 13 & 21,7 \\
& sziromlevelekkel & közepes & 5 & 20 & 33,3 \\
& & nagy & 7 & 21 & 35 \\
\hline 21. & Virág: sziromlevelek & szabadon álló & 1 & 10 & 16,7 \\
& elrendeződése & közbülső & 2 & 21 & 35 \\
& & átfedő & 3 & 29 & 48,3 \\
\hline 22. & Virág: bibék helyzete a & alattuk & 1 & 0 & 0 \\
& portokokhoz viszonyítva & egy szintben & 2 & 32 & 53,3 \\
& & felettük & 3 & 28 & 46,7 \\
\hline
\end{tabular}

\subsubsection{Egyéb virágjellemzők}

A virágok meghatározó színe szirombimbó állapotban a fajták többségénél (58\%) sötét rózsaszín, 27 \%-nál világos rózsaszín (15. táblázat). Középpiros színü virággal csak 8 fajta $(13 \%)$ rendelkezik, ebből négy a Batul fajtacsoportba tartozik. Sárgás rózsaszín virága egyedül a 'Tükör alma'-nak van, míg teljesen fehér, sötétpiros vagy bíborszínü virágú fajta nem található a vizsgált fajták között.

A virágszirmok állása a fajták közel felénél (48 \%) átfedő, harmadánál (35\%) közbülső, és csupán a fajták $16 \%$-a rendelkezik szabadon álló szirmokkal. A bibék a 
portokokhoz viszonyítva a fajták $53 \%$-nál egy szintben, 47 \%-nál felette helyezkednek el. Alsó helyzetü bibéket egyetlen esetben sem tapasztaltunk.

\subsubsection{Gyümölcsjellemzők}

\subsubsection{A gyümölcs mérete}

2007-2011-ben összesen 50 fajta gyümölcsén végeztünk méréseket. 2008-ban végeztünk a legtöbb fajtán pontos méréseket, míg a további években csak ellenőrzésképpen mértünk néhány fajtát, a többi fajta esetében, és a további évek során a kifejeződési fokozatba sorolás már csak megfigyelés alapján történt. Az egyes évek fajtára jellemző gyümölcsmagasság és -

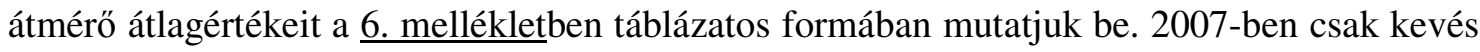
fajtát tudtunk lemérni, így ezek értékeit nem ábrázoljuk külön diagramon. 10 fajtáról ('Budai Domokos', 'Gyógyi piros', 'Marosszéki piros', 'Nemes sóvári', 'Nemes szercsika', 'Orbai alma', 'Szászpap alma', 'Tordai piros kálvil', 'Vajki alma', 'Zöld sóvári’) nincsenek pontos mért adatok, mert nem állt rendelkezésre a minimum 20 darab, megfelelő minőségü, fajtára jellemző alakú, méretü gyümölcs. Ezeknél a kifejeződési fokozat meghatározása becsléssel történt.

A 2008-ban vizsgált 34 fajta gyümölcsének magassága 49-76 mm közé esett, átlagban 63 mm (11. ábra). A fajták többségénél (több mint $80 \%$-a) közepes (50\%) vagy nagy (35\%) gyümölcsmagasságot mértünk. Csupán a fajták $15 \%$-a került a kicsi magasságú kategóriába. A gyümölcsök átmérője 62-92 mm között volt, átlagosan 78 mm (12. ábra). A gyümölcs magasságához hasonlóan az átmérő tekintetében is a közepes (47\%) vagy nagy (41\%) kategóriába került a legtöbb fajta, míg csak 12 \% került a kicsi átmérőjü kategóriába.

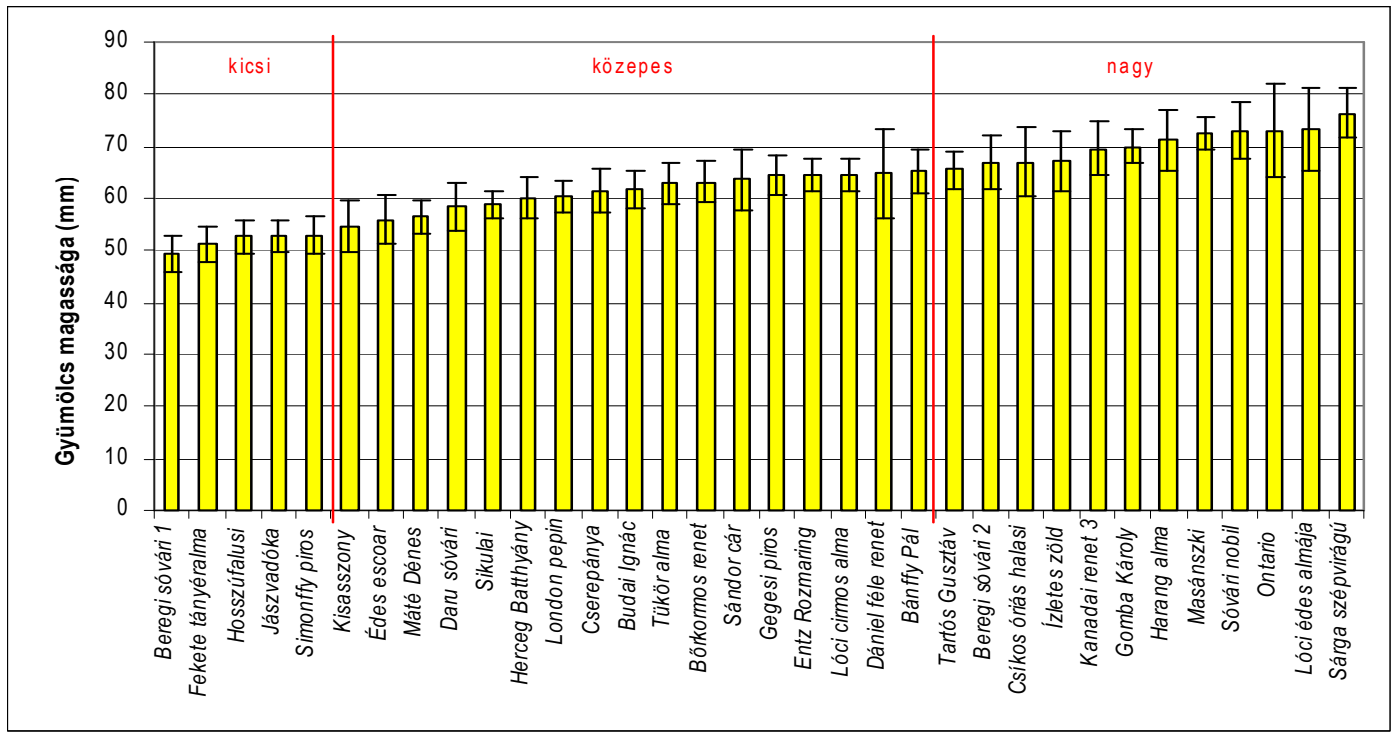

11. ábra. A gyümölcsök magassága szerint kialakított kategóriák (Soroksár, 2008). 
2009-2011-ben a Batul, Sóvári, Renet csoportba tartozó fajtákat, továbbá az 'Entz rozmaring', 'Húsvéti rozmaring', 'Tordai alma', 'Nyári fontos' fajták gyümölcsét mértük le és vizsgáltuk részletesen a fajták hasonlóságának, illetve a fajtacsoportok diverzitásának felmérése érdekében. A három 'Batul' alapfajta és a 'Mosolygós batul' hasonló adatokat mutatott, míg a gyümölcsök magassága alapján a 'Zöld batul' jelentősen magasabb értéket mutatott (13-14. ábra). A Sóvári és Renet fajtacsoportban valamennyi kifejeződési fokozatba kerültek fajták (13-16. ábra). A három 'Kanadai renet' szelekció, valamint a két vélt szinonima fajtapár ('Entz és 'Húsvéti rozmaring', illetve 'Tordai alma' és 'Nyári fontos') nem mutatott nagy eltéréseket, minden esetben egy kifejeződési fokozatot mutattak (13-16. ábra). Ugyanakkor a 'Beregi sóvári' két szelekciója mindegyik évben jelentős méretbeli különbségeket mutatott.

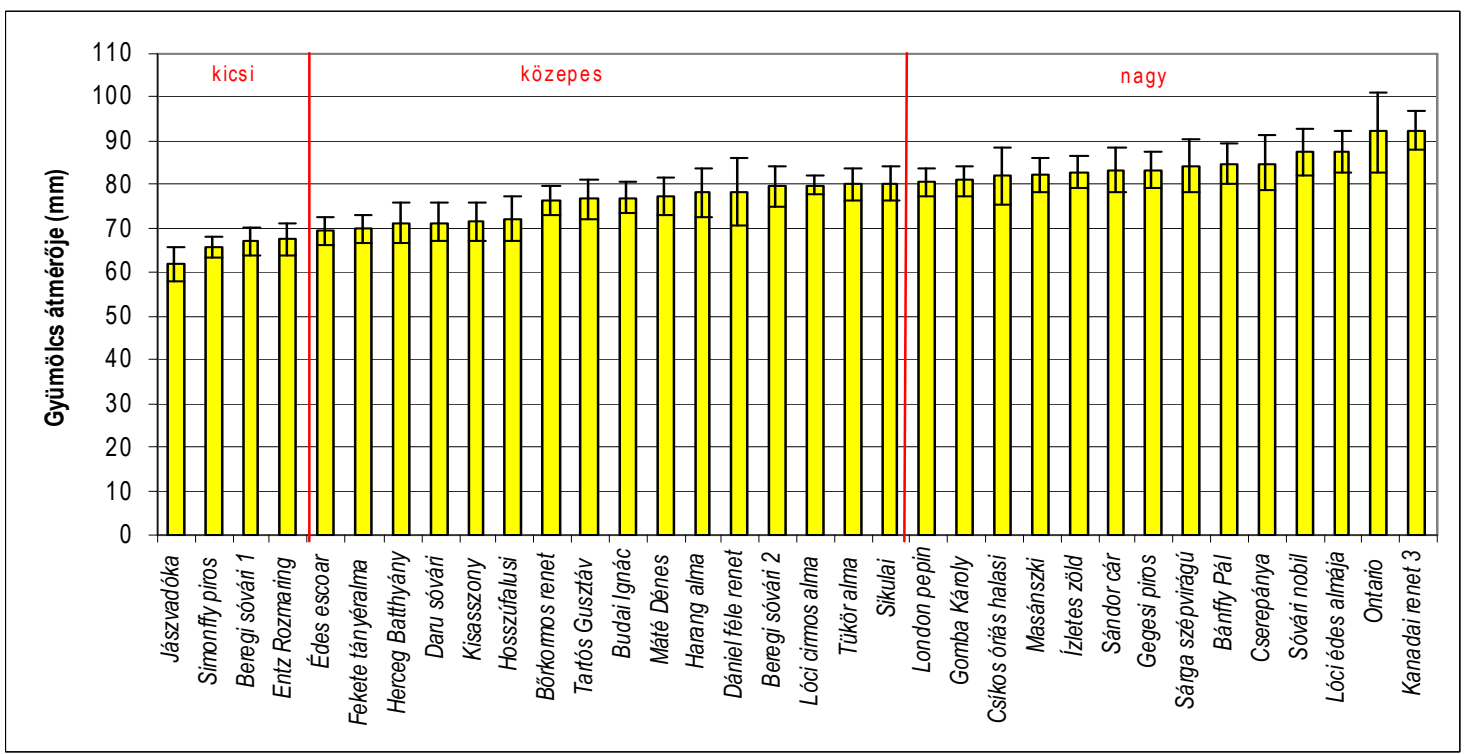

12. ábra. A gyümölcsök átméröje szerint kialakított kategóriák (Soroksár, 2008).

Általában véve a gyümölcsök méretével kapcsolatos vizsgált tulajdonságok egy része mérésen alapul (magasság és átmérö), más része (magasság/átmérő aránya, méret) szubjektív megfigyelés alapján került besorolásra. A 60 fajta tényleges kifejeződési kategóriáit a több éves vizsgálatok alapján készítettük el úgy, hogy a leggyakrabban előforduló kifejeződési fokozatot tekintettük a fajtára jellemzőnek, mint azt a levél és virág esetében már említettük. 

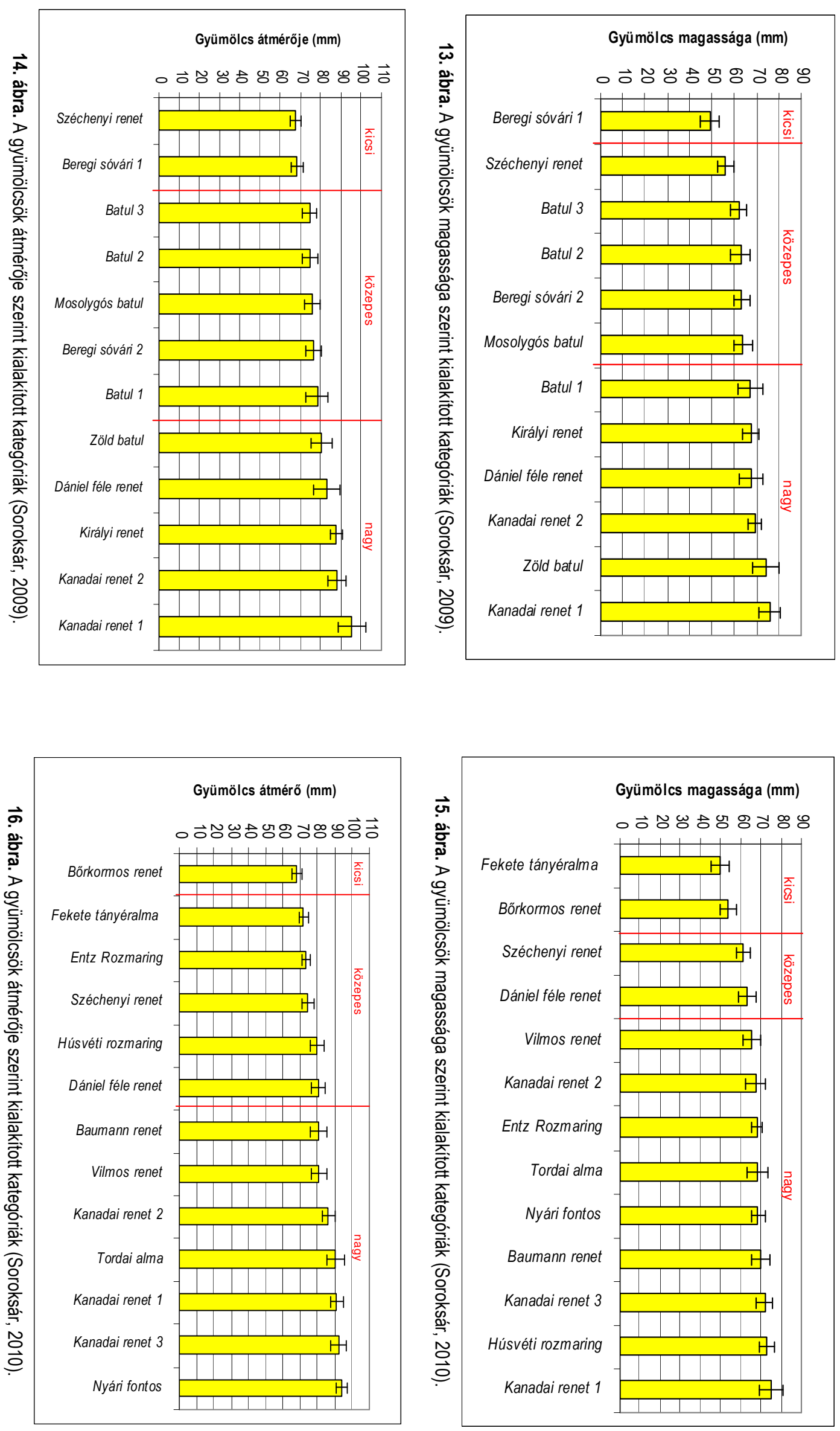
A több éves adatsor alapján a gyümölcsök méretére kialakított 9 kifejezödési fokozatból a fajták 8 csoportba kerültek, mert nagyon kicsi gyümölcsü fajtát nem találtunk az ültetvényben (16. táblázat). A nagyon kicsi-kicsi átmeneti kategóriába csak egy fajtát soroltunk be, és a kicsibe is csak három fajta (5\%) került. A nagyon nagy gyümölcsméret szintén ritka volt, csak 4 fajtánál (7\%) tapasztaltuk. A kicsi-közepestől a nagy-nagyon nagyig terjedő két konkrét és három átmeneti kategóriába került a fajták nagy része, 12 $25 \%$-os arányban.

A több éves mért adatokból kialakított magasság és átmérő kifejeződési fokozatok megoszlása - mindkettő esetében - a következő: 15 \% kicsi, 45 \% közepes és 40 \% nagy (16. táblázat). A magasság/átmérő aránya megadja a gyümölcsök alakindexét. A nagynagyon nagy alakindex a megnyúlt fajtákra jellemző. Nagyon nagy alakindexü, igen megnyúlt fajtát csak egyet találtunk a vizsgált fajták között, míg a megnyúlt alakot jelző nagy alakindex a fajták $18 \%$-át jellemezte. A legtöbb fajta közepes alakindexet mutatott, ami a gömbölyded alakra jellemző. A kicsi alakindex a lapított gömbölyded fajtákat jellemzi, ezt a fajták $13 \%$-ánál tapasztaltuk.

16. táblázat. A gyümölcs méretére vonatkozó tulajdonságok kifejeződési fokozatainak megoszlása a 60 fajtán

\begin{tabular}{|c|c|c|c|c|c|}
\hline $\begin{array}{l}\text { TG/14/9 } \\
\text { sorszám }\end{array}$ & Tulajdonság & Kifejeződési fokozat & Kód & $\begin{array}{l}\text { Fajták } \\
\text { száma }\end{array}$ & $\%$ \\
\hline \multirow[t]{9}{*}{24.} & Gyümölcs: méret & nagyon kicsi & 1 & 0 & 0 \\
\hline & & nagyon kicsi - kicsi & 2 & 1 & 1,7 \\
\hline & & kicsi & 3 & 3 & 5 \\
\hline & & kicsi - közepes & 4 & 7 & 11,7 \\
\hline & & közepes & 5 & 15 & 25 \\
\hline & & közepes - nagy & 6 & 10 & 16,7 \\
\hline & & nagy & 7 & 13 & 21,7 \\
\hline & & nagy - nagyon nagy & 8 & 7 & 11,7 \\
\hline & & nagyon nagy & 9 & 4 & 6,7 \\
\hline \multirow[t]{3}{*}{25.} & Gyümölcs: magasság & kicsi & 3 & 9 & 15 \\
\hline & & közepes & 5 & 27 & 45 \\
\hline & & nagy & 7 & 24 & 40 \\
\hline \multirow[t]{3}{*}{26.} & Gyümölcs: átmérő & kicsi & 3 & 8 & 13,3 \\
\hline & & közepes & 5 & 27 & 45 \\
\hline & & nagy & 7 & 25 & 41,7 \\
\hline \multirow[t]{5}{*}{27.} & Gyümölcs: magasság/átmérő & nagyon kicsi & 1 & 0 & 0 \\
\hline & aránya & kicsi & 3 & 8 & 13,3 \\
\hline & & közepes & 5 & 40 & 66,7 \\
\hline & & nagy & 7 & 11 & 18,3 \\
\hline & & nagyon nagy & 9 & 1 & 1,7 \\
\hline
\end{tabular}

\subsubsection{A gyümölcs alakja, a csésze- és kocsánymélyedés jellemzői}

Az UPOV által meghatározott hét gyümölcsalak (․ melléklet) közül csak négy fordult elö a vizsgált fajták között (17. táblázat). Nem találtunk befüződve hengeres, hengeres és ellipszoid alakú gyümölcsökkel bíró fajtát. Leggyakoribb a gömbölyded (33 \%) és a lapított 
ellipszoid (47\%) alak volt. A fajták $18 \%$-a kúpos alakot mutatott, és csupán az Orbai almánál tapasztaltunk tojás alakú gyümölcsöket.

A gyümölcsök alakjához tartozó bordázottság tekintetében a fajták több mint 80 \%-a nem vagy csak gyengén bordázott a felszínen, és ugyanez érvényes a csészemélyedés szélén megfigyelhető barázdáltságra is. Erősen bordázott felszín és csészemélyedés csak a Londoni pepin-t jellemzi. Enyhe bordázottság a fajták 10 \%-ánál figyelhető meg.

17. táblázat. A gyümölcs alakjára vonatkozó tulajdonságok kifejeződési fokozatainak megoszlása a 60 fajtán

\begin{tabular}{cllccc}
\hline $\begin{array}{c}\text { TG/14/9 } \\
\text { sorszám }\end{array}$ & \multicolumn{1}{c}{ Tulajdonság } & \multicolumn{1}{c}{ Kifejezödési fokozat } & Kód & $\begin{array}{c}\text { Fajták } \\
\text { száma }\end{array}$ & $\%$ \\
\hline 28. & Gyümölcs: alak & befüzödve hengeres & 1 & 0 & 0 \\
& & kúpos & 2 & 11 & 18,3 \\
& & tojás alakú & 3 & 1 & 1,7 \\
& & hengeres & 4 & 0 & 0 \\
& & ellipszoid & 5 & 0 & 0 \\
& & gömbölyded & 6 & 20 & 33,3 \\
& & lapított ellipszoid & 7 & 28 & 46,7 \\
\hline 29. & Gyümölcs: bordázottság & nincs vagy gyenge & 1 & 53 & 88,3 \\
& & közepes & 2 & 6 & 10 \\
& & erös & 3 & 1 & 1,7 \\
\hline 30. & Gyümölcs: barázdáltság a & nincs vagy gyenge & 1 & 52 & 86,7 \\
& csészemélyedés szélén & közepes & 2 & 6 & 10 \\
& & erös & 3 & 2 & 3,3 \\
\hline
\end{tabular}

A 60 vizsgált fajtánál a közepes csészeméret (57\%) fordul elö leggyakrabban, de a kicsi és a nagy kategóriákba is tudtunk sorolni fajtákat (18. táblázat). A csészelevél hosszúságának vizsgálatakor nagyjából azonos arányban sorolódtak a fajták a kicsi, közepes és hosszú kategóriákba. A kocsány- és csészemélyedés mélységére és szélességére vonatkozóan nem találtunk kiemelkedően ritka vagy gyakori elöfordulást, így ezek részletezésétől eltekintünk, a kifejeződési fokozatok pontos arányai megtalálhatók a $\underline{18}$. táblázatban.

A jelenleg üzemi termesztésben szereplő fő árufajták között ritkán előforduló nagyon rövid vagy rövid kocsány a vizsgálatainkban szereplő régi fajták $73 \%$-nál volt megfigyelhető. A nagyon rövid kocsány a gyakorlatban gyakran eredményez szüret elötti gyümölcshullást, mert a gyümölcsök a növekedésük során lenyomják saját magukat a termővesszőről. Nemcsak a mai üzemi fajták között, hanem a vizsgálatainkban is ritkán (csak 3 fajtánál: 'Daru sóvári', 'Édes escoar', ‘Tordai piros kálvil') tapasztaltunk hosszú gyümölcskocsányt. Kocsányvastagság tekintetében a közepes, vagy a vastag volt a leggyakoribb, míg vékony kocsányvastagsággal csak a 'Bőrkormos renet' és a 'Budai Ignác' esetében találkoztunk. 
18. táblázat. A csésze- és kocsánymélyedés jellemzők kifejeződési fokozatainak megoszlása a 60 fajtán

\begin{tabular}{|c|c|c|c|c|c|}
\hline $\begin{array}{l}\text { TG/14/9 } \\
\text { sorszám }\end{array}$ & Tulajdonság & Kifejeződési fokozat & Kód & $\begin{array}{l}\text { Fajták } \\
\text { száma }\end{array}$ & $\%$ \\
\hline \multirow[t]{3}{*}{31.} & Gyümölcs: csésze mérete & kicsi & 3 & 14 & 23,3 \\
\hline & & közepes & 5 & 34 & 56,7 \\
\hline & & nagy & 7 & 12 & 20 \\
\hline \multirow[t]{3}{*}{32.} & Gyümölcs: csészelevél & rövid & 3 & 17 & 28,3 \\
\hline & hosszúsága & közepes & 5 & 22 & 36,7 \\
\hline & & hosszú & 7 & 21 & 35 \\
\hline \multirow[t]{5}{*}{46.} & Gyümölcs: kocsány hosszúsága & nagyon rövid & 1 & 16 & 26,7 \\
\hline & & rövid & 3 & 28 & 46,7 \\
\hline & & közepes & 5 & 13 & 21,7 \\
\hline & & hosszú & 7 & 2 & 3,3 \\
\hline & & nagyon hosszú & 9 & 1 & 1,7 \\
\hline \multirow[t]{3}{*}{47.} & Gyümölcs: kocsány vastagsága & vékony & 3 & 2 & 3,3 \\
\hline & & közepes & 5 & 30 & 50 \\
\hline & & vastag & 7 & 28 & 46,7 \\
\hline \multirow[t]{3}{*}{48.} & Gyümölcs: kocsánymélyedés & sekély & 3 & 19 & 31,7 \\
\hline & mélysége & közepes & 5 & 22 & 36,7 \\
\hline & & mély & 7 & 19 & 31,7 \\
\hline \multirow[t]{3}{*}{49.} & Gyümölcs: kocsánymélyedés & keskeny & 3 & 26 & 43,3 \\
\hline & szélessége & közepes & 5 & 21 & 35 \\
\hline & & széles & 7 & 13 & 21,7 \\
\hline \multirow[t]{3}{*}{50.} & Gyümölcs: csészemélyedés & sekély & 3 & 8 & 13,3 \\
\hline & mélysége & közepes & 5 & 22 & 36,7 \\
\hline & & mély & 7 & 30 & 50 \\
\hline \multirow[t]{3}{*}{51.} & Gyümölcs: csészemélyedés & keskeny & 3 & 17 & 28,3 \\
\hline & szélessége & közepes & 5 & 21 & 35 \\
\hline & & széles & 7 & 22 & 36,7 \\
\hline
\end{tabular}

\subsubsection{A gyümölcs felszíne}

A héj felszínén észlelhető hamvasság a fajták 68 \%-nál nem jellemző, vagy nagyon gyengén jelenik meg (19. táblázat). A vizsgált fajták $25 \%$-a közepesen hamvas, míg csak négy fajta ('Beregi sóvári' 2. genotípusa, 'Harang alma', 'Masánszki', 'Nemes sóvári') héja erősen hamvas. A zsírosság a fajták 60 \%-nál gyenge vagy nem tapasztalható, 25 \%-nál közepes, és csak 15 \%-nál jegyeztünk fel erösen zsíros héjfelszínt.

A gyümölcshéjon a parásodás megjelenhet a gyümölcs oldalán, a kocsány- és/vagy a csészemélyedés körül. Felületi parásodás esetén gyakorlatilag mindig megfigyelhető a csésze és a kocsány környéki parásodás is. Erős felületi parásodás a vizsgált fajtákon belül csak a 'Kanadai renet' szelekcióknál volt megfigyelhető, míg közepes felületi parásodást tapasztaltunk a 'Bőrkormos renet', 'Édes escoar' és a 'Herceg Batthyány’ fajtáknál. A többi 54 fajtánál nem fordult elő parásodás a gyümölcs oldalán.

A paraszemölcsök száma és mérete tekintetében azt tapasztaltuk, hogy a három lehetséges kifejeződési fokozat előfordulási aránya nagyjából azonos. 
19. táblázat. A gyümölcsfelszín jellemzői és kifejeződési fokozatainak megoszlása a 60 fajtán

\begin{tabular}{|c|c|c|c|c|c|}
\hline $\begin{array}{l}\text { TG/14/9 } \\
\text { sorszám }\end{array}$ & Tulajdonság & Kifejeződési fokozat & Kód & $\begin{array}{l}\text { Fajták } \\
\text { száma }\end{array}$ & $\%$ \\
\hline \multirow[t]{3}{*}{33.} & Gyümölcs: héj hamvassága & nincs vagy gyenge & 1 & 41 & 68,3 \\
\hline & & közepes & 2 & 15 & 25 \\
\hline & & erös & 3 & 4 & 6,7 \\
\hline \multirow[t]{3}{*}{34.} & Gyümölcs: héj zsírossága & nincs vagy gyenge & 1 & 36 & 60 \\
\hline & & közepes & 2 & 15 & 25 \\
\hline & & erős & 3 & 9 & 15 \\
\hline \multirow[t]{3}{*}{41.} & Gyümölcs: parásodás felülete a & nincs vagy kicsi & 1 & 28 & 46,7 \\
\hline & kocsány körül & közepes & 2 & 11 & 18,3 \\
\hline & & nagy & 3 & 21 & 35 \\
\hline \multirow[t]{3}{*}{42.} & Gyümölcs: parásodás felülete a & nincs vagy kicsi & 1 & 54 & 90 \\
\hline & gyümölcs oldalán & közepes & 2 & 3 & 5 \\
\hline & & nagy & 3 & 3 & 5 \\
\hline \multirow[t]{3}{*}{43.} & Gyümölcs: parásodás felülete a & nincs vagy kicsi & 1 & 56 & 93,3 \\
\hline & csészemélyedés körül & közepes & 2 & 1 & 1,7 \\
\hline & & nagy & 3 & 3 & 5 \\
\hline \multirow[t]{3}{*}{44.} & Gyümölcs: paraszemölcsök & kevés & 3 & 18 & 30 \\
\hline & száma & közepes & 5 & 20 & 33,3 \\
\hline & & sok & 7 & 22 & 36,7 \\
\hline \multirow[t]{3}{*}{45.} & Gyümölcs: paraszemölcsök & kicsi & 3 & 24 & 40 \\
\hline & mérete & közepes & 5 & 19 & 31,7 \\
\hline & & nagy & 7 & 17 & 28,3 \\
\hline
\end{tabular}

A kocsány körül a fajták közel felénél (47 \%) nem tapasztaltunk parásodást, míg a fajták másik felét közepes (18\%) vagy erős (35\%) parásodás jellemzi. A csészemélyedés körül csupán négy fajtánál jegyeztünk fel közepes ('Bőrkormos renet') vagy nagy ('Kanadai renet' három szelekciója) kiterjedésü parásodást, a többi fajta nem parásodik a csésze környékén.

\subsubsection{A gyümölcs színeződése}

A gyümölcsök színeződésének vizsgálatakor azt tapasztaltuk, hogy két fajtánál ('Édes escoar', 'Herceg Batthyány’) egyáltalán nem fordult elő fedőszín. Ebben az esetben a teljes jellemzés során 0 értéket írtunk be a fedőszín jellemzőihez. A 'Simonffy piros’-nak viszont olyan nagy a fedőszín borítottsága, hogy az alapszíne nem is látható. A gyümölcsökön az alapszín leggyakrabban a sárga (47\%) és a sárgászöld (45\%) volt, de a nagyon ritkán előforduló fehéreszöld ('Ontario’) és zöld ('Beregi sóvári’ 2. genotípusa, 'Bőrkormos renet', 'Masánszki') alapszínü kategóriába is került pár fajta (20. táblázat).

A fedőszín viszonylagos felületét vizsgálva a fajták 80 \%-a gyenge-közepes mértékü színeződést mutatott. A hamvasság letörlése után látható fedőszín a fajták harmadánál narancsvörös (32\%), másik harmadánál piros (37\%), $18 \%$-nál rózsaszín-piros, és $8 \%$-nál bíborpiros. Barnáspiros fedőszínnel csak a 'Masánszki' fajta bír. A fedőszín intenzitás tekintetében nem tapasztaltunk kiugró arányokat, a világos, közepes és a sötét színintenzitás egyaránt előfordult. 
A fedőszín jellegének feljegyzésekor a csak mosott fedőszín 38 \%-ban, csak csíkozott 8 \%-ban fordult elö, míg a különböző mértékben (gyengén vagy erösen) mosott és csíkozott színeződés előfordulása volt a leggyakoribb, a fajták 50 \%-nál tapasztaltuk valamelyik típust. Márványozott fedőszínü fajtát nem találtunk a vizsgált fajták között. Az önmagában vagy mosott színnel kombinált csíkozottságot mutató fajták többsége közepes szélességü csíkokat mutatott, de keskeny és széles csíkozottság is megfigyelhető volt.

20. táblázat. A gyümölcsszíneződés kifejeződési fokozatainak megoszlása a 60 fajtán

\begin{tabular}{|c|c|c|c|c|c|}
\hline $\begin{array}{l}\text { TG/14/9 } \\
\text { sorszám }\end{array}$ & Tulajdonság & Kifejeződési fokozat & Kód & $\begin{array}{l}\text { Fajták } \\
\text { száma }\end{array}$ & $\%$ \\
\hline \multirow[t]{6}{*}{35.} & Gyümölcs: alapszín & nem látható & 1 & 1 & 1,7 \\
\hline & & fehéressárga & 2 & 0 & 0 \\
\hline & & sárga & 3 & 28 & 46,7 \\
\hline & & fehéreszöld & 4 & 1 & 1,7 \\
\hline & & sárgászöld & 5 & 27 & 45 \\
\hline & & zöld & 6 & 3 & 5 \\
\hline \multirow[t]{5}{*}{36.} & Gyümölcs: fedőszín & nincs vagy nagyon kicsi & 1 & 13 & 21,7 \\
\hline & viszonylagos felülete & kicsi & 3 & 21 & 35 \\
\hline & & közepes & 5 & 14 & 23,3 \\
\hline & & nagy & 7 & 9 & 15 \\
\hline & & nagyon nagy & 9 & 3 & 5 \\
\hline \multirow[t]{6}{*}{37.} & Gyümölcs: fedőszín árnyalata - & nincs & 0 & 2 & 3,3 \\
\hline & hamvasság letörlése után & narancsvörös & 1 & 19 & 31,7 \\
\hline & & rózsaszín-piros & 2 & 11 & 18,3 \\
\hline & & piros & 3 & 22 & 36,7 \\
\hline & & bíborpiros & 4 & 5 & 8,3 \\
\hline & & barnáspiros & 5 & 1 & 1,7 \\
\hline \multirow[t]{4}{*}{38.} & Gyümölcs: fedőszín intenzitása & nincs & 0 & 2 & 3,3 \\
\hline & & világos & 3 & 27 & 45 \\
\hline & & közepes & 5 & 18 & 30 \\
\hline & & sötét & 7 & 13 & 21,7 \\
\hline \multirow[t]{8}{*}{39.} & Gyümölcs: fedőszín jellege & nincs & 0 & 2 & 3,3 \\
\hline & & csak mosott & 1 & 23 & 38,3 \\
\hline & & mosott és gyengén csíkozott & 2 & 18 & 30 \\
\hline & & mosott és erősen csíkozott & 3 & 11 & 18,3 \\
\hline & & gyengén mosott és erősen csíkozott & 4 & 1 & 1,7 \\
\hline & & csak csíkozott (nem mosott) & 5 & 5 & 8,3 \\
\hline & & mosott és márványozott & 6 & 0 & 0 \\
\hline & & mosott, csíkozott és márványozott & 7 & 0 & 0 \\
\hline \multirow[t]{4}{*}{40.} & Gyümölcs: csíkok szélessége & nincs & 0 & 25 & 41,7 \\
\hline & & keskeny & 3 & 10 & 16,7 \\
\hline & & közepes & 5 & 20 & 33,3 \\
\hline & & széles & 7 & 5 & 8,3 \\
\hline
\end{tabular}

\subsubsection{A gyümölcshús jellemzői}

A gyümölcshús esetében vizsgáltuk a húskeménységet és hús színét, továbbá a magház nyitottságát. Nagyon kemény hússzilárdságú fajtát nem találtunk (21. táblázat). Nagyon puha húsa csak a korai érésü 'Orbai alma'-nak és 'Széchenyi renet'-nek van. A többi fajta puha (27\%), közepes (35\%) vagy kemény (35\%) hússzilárdságú. A hús színének vizsgálatakor azt tapasztaltuk, hogy a fajták fele fehér, a másik fele pedig krémszínủ (13\%) vagy sárgás 
(13\%) vagy zöldes (23\%) hússzínnel rendelkezik. Rózsaszínü vagy pirosas hússzínü fajta nem fordult elö, azonban egyes években a 'Simonffy piros' húsa a héj alatt rózsaszínes színeződést mutatott.

A magrekeszek nyitottságát a keresztbe vágott gyümölcsökön vizsgáltuk. A fajták 88 \%-a kedvező, zárt vagy kissé nyitott magházzal rendelkezik. Mérsékelten nyitott magrekeszü a 'Csíkos óriás halasi' és a 'Vajki alma', míg teljesen nyitott magrekeszü a 'Gegesi piros', 'Lóci édes almája', 'Orbai alma’, 'Tordai piros kálvil’, ‘Tükör alma'.

21. táblázat. A gyümölcshús jellemzők kifejeződési fokozatainak megoszlása a 60 fajtán

\begin{tabular}{|c|c|c|c|c|c|}
\hline $\begin{array}{c}\text { TG/14/9 } \\
\text { sorszám }\end{array}$ & Tulajdonság & Kifejeződési fokozat & Kód & $\begin{array}{l}\text { Fajták } \\
\text { száma }\end{array}$ & $\%$ \\
\hline \multirow[t]{5}{*}{52.} & Gyümölcs: hús szilárdsága & nagyon puha & 1 & 2 & 3,3 \\
\hline & & puha & 3 & 16 & 26,7 \\
\hline & & közepes & 5 & 21 & 35 \\
\hline & & szilárd & 7 & 21 & 35 \\
\hline & & nagyon szilárd & 9 & 0 & 0 \\
\hline \multirow[t]{6}{*}{53.} & Gyümölcs: hús színe & fehér & 1 & 30 & 50 \\
\hline & & krémszínü & 2 & 8 & 13,3 \\
\hline & & sárgás & 3 & 8 & 13,3 \\
\hline & & zöldes & 4 & 14 & 23,3 \\
\hline & & rózsaszínü & 5 & 0 & 0 \\
\hline & & pirosas & 6 & 0 & 0 \\
\hline \multirow[t]{3}{*}{54.} & Gyümölcs: magrekeszek & zárt vagy kissé nyitott & 1 & 53 & 88,3 \\
\hline & nyitottsága (keresztmetszetben) & mérsékelten nyitott & 2 & 2 & 3,3 \\
\hline & & teljesen nyitott & 3 & 5 & 8,3 \\
\hline
\end{tabular}

\subsection{A fajták jellemzése a számkulcsos besorolásuk szerint}

A fajták UPOV TG/14/9 irányelveiben meghatározott 56 tulajdonság szerinti teljes

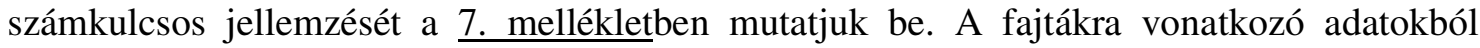

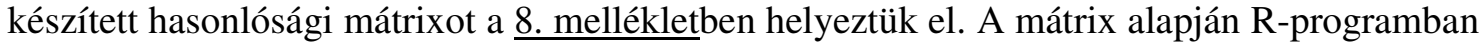
ward módszerrel készítettük el a hierarchikus klaszteranalízist (17. ábra). A fenotípus alapján készített hasonlósági mátrixot 56 tulajdonság figyelembe vételével készítettük, amely alaposabb elkülönítést tesz lehetővé, mintha csak az UPOV 8 csoportosító tulajdonságát vettuik volna figyelembe.

A dendrogramon jól látszik a hat csoport. Egy-egy külön föklasztert alkot a Batul fajtacsoport, ill. a 'Kanadai renet' genotípusok.

Az első főklaszterbe - a 'Zöld batul' kivételével - a Batul fajtacsoport fajtái kerültek. A 'Batul' 1. és 3. genotípusa $100 \%$ egyezést mutat az adatok alapján. A 'Batul' 2. genotípusa három tulajdonságban kissé eltér ezektől, de a dendrogramon mégis nagyon közel helyezkedik el a 'Batul' 1. és 3. genotípusához (mivel ez az eltérés kvantitatív tulajdonságokban van, és ezek közül csak egy tulajdonságnál van két fokozat eltérés, ami az 
egyértelmü különbséget jelezné). Hasonló a helyzet a 'Mosolygós batul'-lal is. A 'Zöld batul' egy teljesen másik föklaszterbe került, távol a többi vizsgált 'Batul' genotípustól.

A második föklasztert a 'Kanadai renet' egyedek alkotják (17. ábra). A különböző szórványgyümölcsösökből begyüjtött 'Kanadai renet' genotípusok esetében nem tudtunk különbséget tenni, ami jó eredménynek számít, hiszen az azonosság bizonyítása volt a cél. Két tulajdonságban (kocsány vastagsága és gyümölcshús színe) ugyan eltérő adatot kaptunk a 'Kanadai renet' 1. genotípusánál, de ez adódhat az eltérő időben történő vizsgálatból, ill. a vizsgálatot végző személy szubjektivitásából is.

A másik négy főklaszterbe került fajták között nem fedezhetők fel fajtacsoportok (17. ábra). Renet fajtákat mind a négy csoportban megtalálhatunk. A Sóvári fajtacsoport három fajtája ('Nemes sóvári', 'Zöld sóvári', 'Daru sóvári') egy kisebb klasztert alkot. Ugyanabban a főklaszterbe, de tőlük kicsit távolabb, külön alklaszterbe került a 'Sóvári nobil'. Az azonos fajtaként ismert 'Nemes sóvári' és a vizsgálatban szereplő 'Sóvári nobil' külön csoportba került, tehát nem nevezhetjük szinonimának. A 'Beregi sóvári' genotípusokat a többi Sóvárihoz képest teljesen külön föklaszterben találjuk. A két 'Beregi sóvári' genotípus (angliai és kárpátaljai) a számkulcsos jellemzés alapján (7. melléklet) nem mutat hasonlóságot, így két külön fajtáról lehet szó.

Közeli rokonságot fedezhetünk fel a 'Nyári fontos' és a 'Tordai alma', illetve az 'Entz rozmaring' és a 'Húsvéti rozmaring' fajták között. Az 'Entz rozmaring' és a 'Húsvéti rozmaring' fajták esetében ez nem meglepő, hiszen számos szakirodalmi leírás azonos fajtának tekinti őket. A 'Nyári fontos' és a 'Tordai alma' közel 100 \%-os morfológiai hasonlóságából levonható következtetésre viszont a markeranalízistől várjuk a választ. A gyakran szinonimaként ismert 'Cigány alma' és 'Simonffy piros' fajták viszont két külön klaszterbe kerültek (17. ábra). A számkulcsos jellemzés is azt mutatja, hogy a tulajdonságok közel $50 \%$-ában tapasztalható eltérést a két fajta között (․ melléklet).

Érdekes viszont, hogy a megfigyeléseink szerint parthenokarpiára nagymértékben hajlamos fajták ('Orbai alma', 'Tordai piros kálvil', 'Vajki alma') közös klasztert alkotnak a dendrogramon, bár a fajták közti távolság nagy (17. ábra).

A vizsgált fajták között nemcsak a Kárpát-medencében keletkezett, hanem hazánkban elterjedt, de vélhetően vagy biztosan nem magyar származású fajták is voltak pl. 'Kanadai renet', 'Ontario', 'Tartós Gusztáv', 'Londoni pepin', 'Sárga szépvirágú'. A fajták eredeti, szakirodalom szerinti származását a Vizsgálatok anyaga és helyszíne fejezetben, az 1. táblázatban feltüntettük. A $\underline{17}$. ábrán bemutatott, morfológián alapuló dendrogramon az endemikus fajták nem különülnek el élesen a külföldi származású fajtáktól, a 'Kanadai renet' kivételével, mely külön csoportot alkot. 


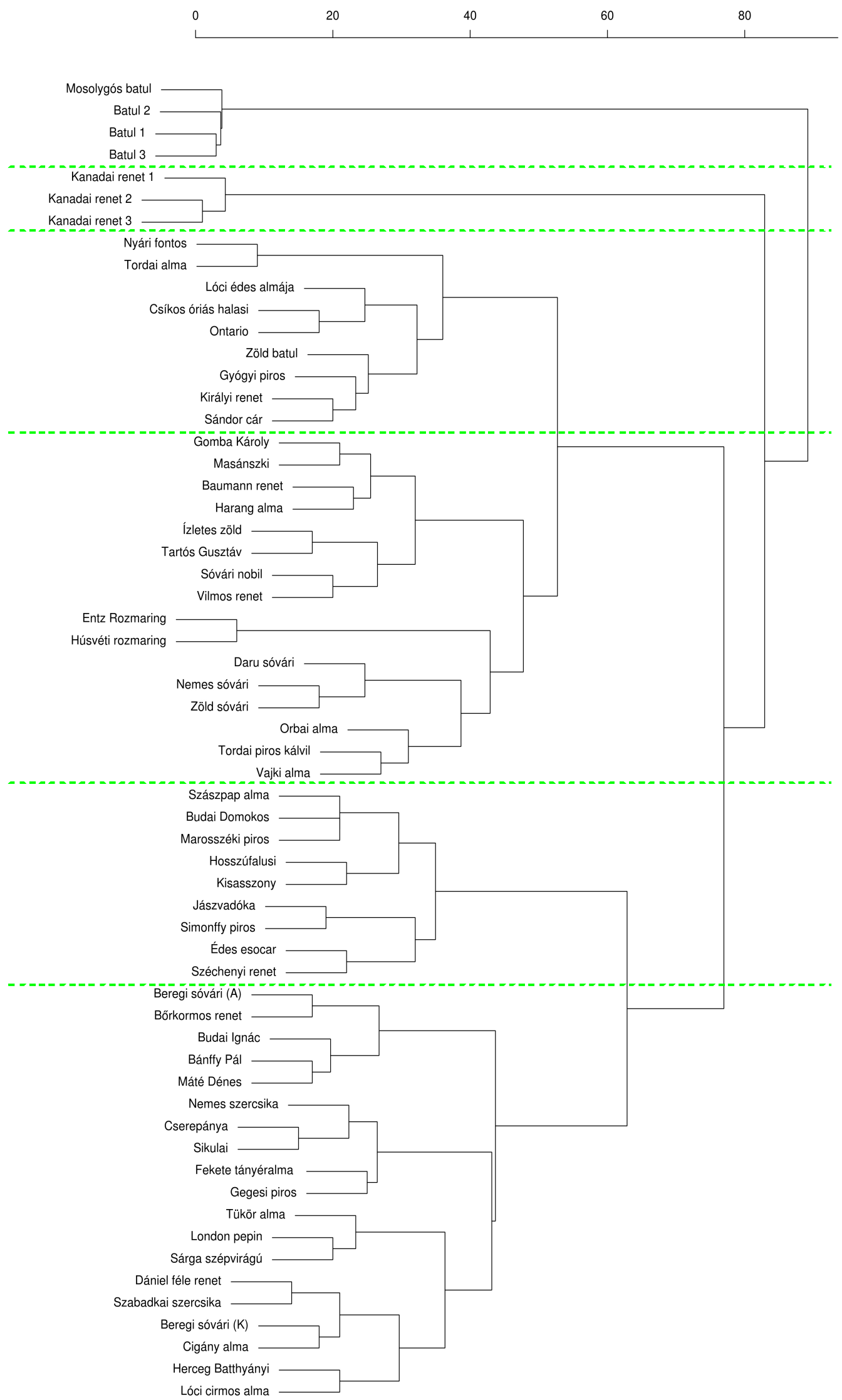

17. ábra. A faják rokonsági viszonyai a fenotípusos UPOV számkulcsokból készitett hasonlósági mátrix alapján ( $A=a n g l i a i$, K=kárpátaljai). 
Sajnos a vizsgálatba vont fajták származására nézve kevés az információ, kb. a 3/4ükről tudjuk biztosan, vagy sejtjük a keletkezés helyét (1. táblázat). A Kárpát-medence egész területéről származnak, de a legtöbb fajta erdélyi. Csak néhány fajta származik Kárpátalja (pl. Sóvári fajták, 'Vajki alma'), Délvidék (pl. 'Szabadkai szercsika'), Alföld (pl. 'Jászvadóka', 'Simonffy piros', 'Harang alma') vagy a Dunántúl ('Herceg Battyhyány’) területéről. A dendrogram nem tükrözi a tájegységeket sem, így a morfológiai hasonlóság nem fedi a származásra vonatkozó ismereteket.

A dendrogramon (17. ábra) az is jól látható, hogy a 'Batul' és 'Kanadai renet' genotípusok kivételével nem tudtunk egyértelmü fajtacsoportokat elkülöníteni. Az egyes alcsoportokba sorolt fajták közötti távolság nagy, ami a vizsgált gyüjtemény nagy biodiverzitását mutatja.

\subsection{Mikroszatellit markerezés eredménye}

\subsubsection{SSR polimorfizmus}

A 73 vizsgált almafajtánál mindegyik felhasznált SSR primerpárral felszaporítottunk mikroszatellit régiókat. A diploid fajták egy vagy kettő fragmentumot amplifikáltak lókuszonként. Abban az esetben, ha csak egy fragmentumot tudtunk detektálni, homozigótának tekintettuik a fajtát az adott lókuszon. Mivel a null allélok jelenlétét nem zárhatjuk ki, előfordulhat, hogy a heterozigótaság értékeket alábecsültük. Az SSR adatokat az Identity 1.0 programmal értékeltük ki, kizárólag a diploid fajták (55) adatai alapján, mert ez a program a triploidokat nem tudja kezelni.

Az 55 diploid fajtánál 12 primerpárral összesen 160 polimorf fragmentumot amplifikáltunk. Az átlagos allélszám 13,33/lókusz. A legtöbb allélt (19) a CH02c02a primerpárral kaptuk, míg a legkevesebbet (10) a CH02c09-cel (22. táblázat). A várható heterozigótaságot $(\mathrm{He})$ befolyásolja az allélok száma és az allélgyakoriság. A várt heterozigótaság (He) 0,77 (CH04e03) és 0,91 (CH02c02a) között alakult, míg az átlag 0,85. A megfigyelt heterozigótaság (Ho) 0,63 (CH05e03) és 0,98 (CH01h01) között volt, míg az átlag 0.83. A null allélok becsült gyakorisága 5 lókusznál $(\mathrm{CH} 02 \mathrm{c} 02 \mathrm{a}, \mathrm{CH} 02 \mathrm{c} 09, \mathrm{CH} 05 \mathrm{e} 03$, CH05d11, CH03a02) adott pozitív értéket, ez azonban nem jelenti szükségszerüen a null allélok jelenlétét, csak annak lehetőségét mutatja.

A további értékek, mint az allélméret intervallumok, a további várt $(\mathrm{He})$ és tapasztalt heterozigótaság (Ho), a null allélok száma (n), az azonosságok valószínüsége (PI) szintén a 22. táblázatban olvashatók.

A mért fragmentumhosszok gyakoriságát a (23. táblázat) mutatjuk be. 
22. táblázat. A 12 SSR lókusz jellemzése az 55 diploid fajta alapján (He=várt heterozigótaság, Ho=megfigyelt heterozigótaság, n=null allélok gyakorisága, PI=azonos genotípus valószínűsége; *=ECPGR által kijelölt primer)

\begin{tabular}{lcccccc}
\hline Lókusz & $\begin{array}{c}\text { Allélok } \\
\text { Száma }\end{array}$ & $\begin{array}{c}\text { Allélméret } \\
\text { intervallumok }\end{array}$ & He & Ho & n & PI \\
\hline CH01f02* & 15 & $170-212$ & 0.8823 & 0.9444 & -0.0329 & 0.0477 \\
CH01h01* & 15 & $104-144$ & 0.8395 & 0.9814 & -0.0771 & 0.0818 \\
CH02c02a & 19 & $127-199$ & 0.9142 & 0.7222 & 0.1003 & 0.0262 \\
CH02c09* & 10 & $231-255$ & 0.8556 & 0.7592 & 0.0519 & 0.0692 \\
CH05e03 & 14 & $146-198$ & 0.8153 & 0.6296 & 0.1022 & 0.0908 \\
CH04e03 & 12 & $185-223$ & 0.7738 & 0.8518 & -0.0439 & 0.1041 \\
CH05d11 & 15 & $163-213$ & 0.8691 & 0.7777 & 0.0488 & 0.0557 \\
CH03g07 & 12 & $116-180$ & 0.8317 & 0.9074 & -0.0412 & 0.0823 \\
CH02c11* & 13 & $206-236$ & 0.8936 & 0.9074 & -0.0072 & 0.0396 \\
CH02d08* & 12 & $207-255$ & 0.8329 & 0.8703 & -0.0203 & 0.0909 \\
CH03a02 & 12 & $119-183$ & 0.8616 & 0.7962 & 0.0350 & 0.0584 \\
CH05c04 & 11 & $179-259$ & 0.7767 & 0.8148 & -0.0214 & 0.1394 \\
\hline
\end{tabular}

23. táblázat. 12 mikroszatellit markerrel kapott allélméretek és allél gyakoriságok (csak a diploid fajtákra nézve, vastag betüvel emeltük ki a legnagyobb allél gyakoriságokat; *=ECPGR által kijelölt primer)

\begin{tabular}{|c|c|c|c|c|c|c|c|c|c|c|c|}
\hline \multicolumn{2}{|c|}{ CH01f02* } & \multicolumn{2}{|c|}{ CH01h01* } & \multicolumn{2}{|c|}{ CH02c02a } & \multicolumn{2}{|c|}{ CH02c09* } & \multicolumn{2}{|c|}{ CH05e03 } & \multicolumn{2}{|c|}{ CH04e03 } \\
\hline $\begin{array}{l}\text { Méret } \\
\text { (bp) }\end{array}$ & $\begin{array}{c}\text { Allél- } \\
\text { gyakoriság }\end{array}$ & $\begin{array}{l}\text { Méret } \\
\text { (bp) }\end{array}$ & $\begin{array}{c}\text { Allél- } \\
\text { gyakoriság }\end{array}$ & $\begin{array}{l}\text { Méret } \\
\text { (bp) }\end{array}$ & $\begin{array}{c}\text { Allél- } \\
\text { gyakoriság }\end{array}$ & $\begin{array}{l}\text { Méret } \\
\text { (bp) }\end{array}$ & $\begin{array}{c}\text { Allél- } \\
\text { gyakoriság }\end{array}$ & $\begin{array}{l}\text { Méret } \\
\text { (bp) }\end{array}$ & $\begin{array}{c}\text { Allél- } \\
\text { gyakoriság }\end{array}$ & $\begin{array}{l}\text { Méret } \\
\text { (bp) }\end{array}$ & $\begin{array}{c}\text { Allél- } \\
\text { gyakoriság }\end{array}$ \\
\hline 170 & 0.1759 & 104 & 0.0092 & 127 & 0.0833 & 231 & 0.2129 & 146 & 0.0092 & 185 & 0.0648 \\
\hline 172 & 0.0277 & 108 & 0.0092 & 129 & 0.0277 & 239 & 0.0185 & 160 & 0.0463 & 187 & 0.0370 \\
\hline 174 & 0.0555 & 110 & 0.0092 & 131 & 0.0092 & 241 & 0.0740 & 162 & 0.3425 & 193 & 0.0277 \\
\hline 176 & 0.0092 & 112 & 0.1111 & 141 & 0.0277 & 243 & 0.2129 & 164 & 0.1388 & 195 & 0.0185 \\
\hline 180 & 0.1666 & 114 & 0.1574 & 145 & 0.0277 & 245 & 0.0092 & 168 & 0.0370 & 197 & 0.4259 \\
\hline 182 & 0.0833 & 116 & 0.1481 & 157 & 0.1296 & 247 & 0.0833 & 170 & 0.0092 & 199 & 0.1481 \\
\hline 184 & 0.1481 & 118 & 0.2685 & 163 & 0.0185 & 249 & 0.0555 & 172 & 0.1759 & 201 & 0.0740 \\
\hline 186 & 0.0092 & 120 & 0.0277 & 167 & 0.1296 & 251 & 0.0925 & 178 & 0.0277 & 203 & 0.0370 \\
\hline 188 & 0.0092 & 122 & 0.0092 & 169 & 0.0092 & 253 & 0.1296 & 180 & 0.0185 & 205 & 0.0833 \\
\hline 190 & 0.0833 & 124 & 0.0092 & 171 & 0.0555 & 255 & 0.1111 & 184 & 0.0463 & 209 & 0.0277 \\
\hline 202 & 0.0092 & 126 & 0.0092 & 175 & 0.1296 & & & 188 & 0.0092 & 211 & 0.0277 \\
\hline 206 & 0.0463 & 128 & 0.0555 & 177 & 0.0370 & & & 190 & 0.0925 & 223 & 0.0277 \\
\hline 208 & 0.1203 & 130 & 0.1574 & 179 & 0.1018 & & & 192 & 0.0370 & & \\
\hline 210 & 0.0463 & 142 & 0.0092 & 181 & 0.0370 & & & 198 & 0.0092 & & \\
\hline 212 & 0.0092 & 144 & 0.0092 & 183 & 0.0648 & & & & & & \\
\hline & & & & 185 & 0.0648 & & & & & & \\
\hline & & & & 187 & 0.0092 & & & & & & \\
\hline & & & & 191 & 0.0092 & & & & & & \\
\hline & & & & 199 & 0.0277 & & & & & & \\
\hline & H05d11 & & H03g07 & & H02c11* & & I02d08* & & H03a02 & & H05c04 \\
\hline $\begin{array}{l}\text { Méret } \\
\text { (bp) }\end{array}$ & $\begin{array}{c}\text { Allél } \\
\text { gyakoriság }\end{array}$ & $\begin{array}{l}\text { Méret } \\
\text { (bp) }\end{array}$ & $\begin{array}{c}\text { Allél } \\
\text { gyakoriság }\end{array}$ & $\begin{array}{l}\text { Méret } \\
\text { (bp) }\end{array}$ & $\begin{array}{c}\text { Allél } \\
\text { gyakoriság }\end{array}$ & $\begin{array}{l}\text { Méret } \\
\text { (bp) }\end{array}$ & $\begin{array}{c}\text { Allél } \\
\text { gyakoriság }\end{array}$ & $\begin{array}{l}\text { Méret } \\
\text { (bp) }\end{array}$ & $\begin{array}{c}\text { Allél } \\
\text { gyakoriság }\end{array}$ & $\begin{array}{l}\text { Méret } \\
\text { (bp) }\end{array}$ & $\begin{array}{c}\text { Allél } \\
\text { gyakoriság }\end{array}$ \\
\hline 163 & 0.0185 & 116 & 0.1851 & 206 & 0.1388 & 207 & 0.0092 & 119 & 0.1388 & 179 & 0.0185 \\
\hline 169 & 0.1574 & 118 & 0.0277 & 214 & 0.0185 & 211 & 0.2129 & 121 & 0.0463 & 185 & 0.3425 \\
\hline 171 & 0.0925 & 120 & 0.0925 & 216 & 0.1111 & 213 & 0.0092 & 123 & 0.0463 & 187 & 0.0092 \\
\hline 173 & 0.1296 & 122 & 0.0277 & 218 & 0.0463 & 217 & 0.1296 & 133 & 0.0925 & 195 & 0.0092 \\
\hline 175 & 0.2314 & 124 & 0.1111 & 220 & 0.0555 & 223 & 0.0370 & 135 & 0.2685 & 199 & 0.1018 \\
\hline 177 & 0.1388 & 126 & 0.3055 & 222 & 0.0277 & 225 & 0.2129 & 137 & 0.0277 & 203 & 0.0092 \\
\hline 181 & 0.0463 & 136 & 0.0092 & 224 & 0.0092 & 227 & 0.0092 & 145 & 0.1296 & 205 & 0.0092 \\
\hline 187 & 0.0185 & 152 & 0.0463 & 226 & 0.0740 & 229 & 0.0740 & 155 & 0.0185 & 207 & 0.2777 \\
\hline 195 & 0.0277 & 166 & 0.0555 & 228 & 0.0833 & 247 & 0.0463 & 157 & 0.0555 & 209 & 0.0555 \\
\hline 197 & 0.0185 & 170 & 0.0185 & 230 & 0.1018 & 249 & 0.0092 & 179 & 0.0370 & 257 & 0.0648 \\
\hline 199 & 0.0092 & 176 & 0.0092 & 232 & 0.1759 & 253 & 0.0277 & 181 & 0.1018 & 259 & 0.1018 \\
\hline 205 & 0.0277 & 180 & 0.1111 & 234 & 0.0463 & 255 & 0.2222 & 183 & 0.0370 & & \\
\hline 207 & 0.0277 & & & 236 & 0.1111 & & & & & & \\
\hline 211 & 0.0463 & & & & & & & & & & \\
\hline 213 & 0.0092 & & & & & & & & & & \\
\hline
\end{tabular}


Minden mikroszatellit lókusz esetén megfigyelhető 1-3 allél, amely jóval nagyobb gyakorisággal fordul elő, mint az adott lókusz többi allélja. Általában a legnagyobb gyakoriságú allél, vagy allélok tekinthetők „vad típusúnak” és a többi allél ezekből mutációval alakulhatott ki. A 12 SSR lókuszon detektált allélokat gyakoriság szerinti négy kategóriába soroltuk (24. táblázat). A nagyon gyakori kategóriába $(0,20$ feletti gyakoriságú) csak 13 allél (8\%) került. Gyakorinak a 0,05 és 0,2 közötti allél gyakoriságot tekintettük, amely kategóriába 61 allél (38\%) került. Összesen 49 ritka (31\%) allélt találtunk, melyek gyakorisága 0,05-0,01 volt. Két lókusz (CH04e03 és CH03a02) kivételével minden lókuszon találtunk egyedi (0,01 alatti gyakoriságú) allélokat, a 12 lókuszon összesen 37 allélt (23\%). Az egyedi allélok lókuszonkénti száma 1 és 8 között változik.

24. táblázat. A 12 SSR lókuszon detektált allélok gyakoriság szerinti megoszlása (csak a diploid fajtákra nézve; *=ECPGR által kijelölt primer)

\begin{tabular}{lcccc}
\hline Lókusz & $\begin{array}{c}\text { Nagyon gyakori } \\
(\mathbf{0 , 2 <})\end{array}$ & $\begin{array}{c}\text { Gyakori } \\
(\mathbf{0 , 0 5}-\mathbf{0 , 2})\end{array}$ & $\begin{array}{c}\text { Ritka } \\
(\mathbf{0 , 0 5}-\mathbf{0 , 0 1})\end{array}$ & $\begin{array}{c}\text { Egyedi } \\
(\sim \mathbf{0 , 0 1}>)\end{array}$ \\
\hline CH01f02* & 0 & 7 & 3 & 5 \\
CH01h01* & 1 & 5 & 1 & 8 \\
CH02c02a & 0 & 8 & 6 & 5 \\
CH02c09* & 2 & 6 & 1 & 1 \\
CH05e03 & 1 & 3 & 5 & 5 \\
CH04e03 & 1 & 4 & 7 & 0 \\
CH05d11 & 1 & 4 & 8 & 2 \\
CH03g07 & 1 & 5 & 4 & 2 \\
CH02c11* & 0 & 8 & 4 & 1 \\
CH02d08* & 3 & 2 & 3 & 4 \\
CH03a02 & 1 & 5 & 6 & 0 \\
CH05c04 & 2 & 4 & 1 & 4 \\
\hline Összesen & 13 & 61 & 49 & 23,1 \\
\hline \% & 8,1 & 38,1 & 30,6 & \\
\hline
\end{tabular}

\subsubsection{Fajtaazonosítás és a fajtacsoportok értékelése az allélösszetétel és klaszteranalízis alapján}

A fenológiai és morfológiai vizsgálatokba bevont fajták körét bővítettük a molekuláris vizsgálatban. Ennek oka, hogy néhány fajta (pl. 'Téli sóvári', 'Fehér batul') nem található meg a gyüjteményünkben, de sikerült levélmintát szerezni, így a Batul és a Sóvári fajtacsoportba tartozó fajták körét bővíteni tudtuk a teljesebb körü vizsgálat érdekében. A 'Honti alma'-t azért vizsgáltuk, mert egyes szakirodalmak (Angyal 1926, Brózik és Régius 1957) a 'Honti alma' - 'Entz rozmaring' - 'Húsvéti rozmaring' fajtákat szinonimának tartják. A 'Jonathan', 'Téli arany parmen', 'Török Bálint' fajták, mint a 'Budai Domokos' és a 'Fertődi téli' nemesítő által leírt szülőfajtái szerepeltek a vizsgálatban, a fajtaazonosság érdekében több termőhelyröl származó mintával.

A vizsgálat során 78 (ebből öt kontroll) alma genotípus mikroszatellit ujjlenyomatát határoztuk meg, melyek között 47 régi kárpát-medencei származású, 7 ismeretlen, de 
vélhetően magyar származású, 16 régi a Kárpát-medencében elterjedt, de külföldi, 5 nemzetközi kontroll, valamint 3 bizonytalan (magyar vagy külföldi) származású fajta, illetve

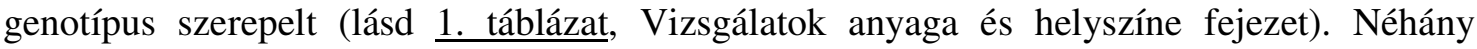
fajtából több genotípust is vizsgáltunk a fajtaazonosság, a számos változat vagy a vitatott származás miatt.

A fajták allélösszetételét a 25. táblázatban mutatjuk be. Összesen 68 különböző genetikai profilt kaptunk. A 'Kanadai renet' három mintája 100 \%-ban azonosnak bizonyult. A 'Téli arany parmen', a 'Honti alma', 'Fertődi téli', valamint a 'Török Bálint' fajták két különböző termőhelyről származó mintái szintén 100 \%-os allélegyezést mutattak, így ezek a minták fajtaazonosnak tekinthetők. $100 \%$-ban azonos genetikai ujjlenyomatot kaptunk a 'Nyári fontos' és 'Tordai alma', a 'Húsvéti rozmaring' és 'Entz rozmaring', valamint a 'Batul' 2. és 3. genotípusa és a 'Mosolygós batul' mintáknál.

A különböző termőhelyekröl begyüjtött, az azonosnak vélt 'Budai Domokos' minták nem mutattak teljes egyezést (részletesebben lásd a szülőazonosítás alfejezetben).

Három különböző allélt detektáltunk összesen 23 mintánál 2-9 számú lókuszon. A két 'Honti alma', illetve a három 'Kanadai renet' $100 \%$-ban azonos genotípusát egynek számítva, 14 régi magyar és 6 régi külföldi fajta mutatkozott triploidnak az allélösszetétele alapján, de a pontos ploidszintet más módszerekkel kiegészítve adhatjuk meg. A fajták flow cytométeres poliditás vizsgálatát megkezdtük, de még nincsenek végleges eredmények, így csak a mikroszatellit vizsgálatok eredményei alapján feltételezzük a ploidszintet.

A markeranalízis során kapott fragmentumhosszokból a Jaccard-indexen alapuló genetikai távolság mátrix alapján (9. melléklet) készített dendrogramon (18. ábra) kilenc nagy csoportot figyelhetünk meg. A morfológiai adatok alapján készített dendrogramhoz hasonlóan az egyes főklaszterekbe került fajták között nem tapasztaltunk származásbeli azonosságokat. Mind a külföldi régi és a modern fajták, mind a Kárpát-medence különböző részeiről származó fajták vegyes eloszlást mutatnak. Érdekes viszont, hogy a 'Tartós Gusztáv', valamint az 'Édes escoar' és a 'Marosszéki piros' egy-egy külön főklasztert képeznek.

A dendrogram egyik élesen elkülönülő kisebb klaszterét a Batul genotípusok adják, a 'Zöld batul' kivételével. A 'Batul' 2. és 3. genotípusa és a 'Mosolygós batul' azonos allélösszetétellel rendelkezik, a vizsgált 12 lókuszban 100 \%-ban ugyanazok az allélok voltak kimutathatók, míg a 'Batul' 1. genotípusa és a 'Fehér batul' csak egyetlen lókuszon (CH01h01) mutatott 2 bp különbséget a fenti három fajtától. Ezzel szemben a 'Zöld batul' csak négy lókusz egy-egy alléljában mutatott hasonlóságot a 'Batul' többi vizsgált típusához, és a dendrogramon is teljesen külön csoportba került. 
25. táblázat. A vizsgált fajták allélösszetétele a 12 SSR lókuszon (*=ECPGR által kijelölt primer)

\begin{tabular}{|c|c|c|c|c|c|c|c|c|c|c|c|c|}
\hline Fajta & CH01f02* & CH01h01* & CH02c02a & CH02c09* & CH05e03 & CH04e03 & CH05d11 & CH03g07 & CH02c11* & CH02d08* & CH03a02 & CH05c04 \\
\hline Bánffy Pál & 170:180 & 110:112 & 129:171 & $241: 253$ & 172 & 197 & 175 & 126:166 & $222: 236$ & $217: 225$ & 133:145 & 185 \\
\hline Batul 1 & 190:210 & 116 & 167 & 243:249 & 164 & 197 & $177: 211$ & 116:180 & $234: 236$ & 211:225 & 119:135 & $207: 259$ \\
\hline Batul 2 & $190: 210$ & $114: 118$ & 167 & 243:249 & 164 & 197 & $177: 211$ & 116:180 & $234: 236$ & 211:225 & 119:135 & $207: 259$ \\
\hline Batul 3 & 190:210 & 114:118 & 167 & 243:249 & 164 & 197 & 177:211 & 116:180 & $234: 236$ & 211:225 & 119:135 & $207: 259$ \\
\hline Baumann renet & 170:184 & $112: 120$ & 179 & $231: 243$ & 172 & $185: 223$ & $171: 173$ & $126: 136$ & 216:226 & 211:225 & 135:181 & 187:207 \\
\hline Beregi sóvári 1 & 184 & 114:128 & 127:181 & 251 & 160:164 & 193:197 & 175:205 & 124:126 & 206:216 & $211: 255$ & 135:145 & 185 \\
\hline Beregi sóvári 2 & 180:206 & 112:130 & 143:181 & 231 & $162: 172$ & 197 & 171:175 & 126:170 & 218:224 & $211: 225: 255$ & 119:133:145 & 185:207 \\
\hline Bőrkormos renet & 184:190 & 114:118 & 175:185 & $251: 253$ & 190 & 197:201 & 177:181 & $124: 126$ & $220: 230$ & $225: 255$ & 135:145 & $185: 207$ \\
\hline Budai Domokos (F) & 170:212 & 118:130 & 175:185 & $231: 245$ & 164:184 & 197:203 & 169:175 & 116:120 & $228: 232$ & $217: 255$ & 135 & $185: 207$ \\
\hline Budai Domokos (S) & 170:208 & $118: 130$ & $175: 185$ & $231: 247$ & $164: 184$ & 197:203 & $169: 175$ & $116: 120$ & $228: 232$ & $217: 255$ & 135 & $185: 207$ \\
\hline Budai Domokos (Ú) & 170:182 & 112:116 & 157:183 & 253 & 162:192 & 187:197 & 181 & 118:126 & $224: 230$ & 217 & 121:135 & 185 \\
\hline Budai Ignác & 180:184 & 118:128 & $127: 199$ & $247: 253$ & $164: 190$ & 199 & $169: 175$ & 126: 152 & 206:232 & $227: 229$ & 155:181 & $209: 259$ \\
\hline Cigány alma & 170:180:188 & 112:116 & 129:157 & $231: 239$ & 162:172 & 197:205 & 175:187 & 120:126:170 & 216:220 & 211:217:255 & 135:145 & 179:207 \\
\hline Cserepánya & 180:184:206 & 116:118:120 & 141:149:179 & 231:243:255 & 158:162:190 & 197:205 & 171:173:177 & 116:120 & 206:218:236 & 211 & $137: 145: 157$ & 185:199:207 \\
\hline Csíkos óriás halasi & 170:180:206 & 114:130 & 141:157:183 & $231: 249$ & 162:172 & 199:203 & $171: 175$ & 122:126:170 & 206:218:226 & $225: 255$ & 119:133 & 185:203 \\
\hline Dániel féle renet & 170:180:188 & 112:116 & 129:157 & $231: 239$ & $162: 172$ & 197:205 & 175:187 & 120:126:170 & 216:220 & 211:217:255 & 135 & 179:207 \\
\hline Daru sóvári & 170:208 & $114: 118$ & $157: 177$ & 243 & $162: 172$ & 197:201 & 169:177 & 126:180 & $222: 232$ & $225: 255$ & $135: 183$ & $185: 207$ \\
\hline Édes esocar & 182:190 & 118:120 & 175 & 251 & 160 & 197:205 & 181:195 & 122:170 & 216:232 & $217: 225$ & 137:145 & 185:195 \\
\hline Entz Rozmaring & 170:184 & 112 & 171:185:191 & $243: 247: 253$ & 162:172:190 & 193:197:203 & $187: 195: 205$ & 116:124:126 & $222: 232$ & $211: 217: 247$ & $135: 145$ & $185: 207$ \\
\hline Fehér batul & 190:210 & 116:118 & 167 & 243:249 & 164 & 197 & $177: 211$ & 116:180 & $234: 236$ & $211: 225$ & 119:135 & 207:259 \\
\hline Fekete tányéralma & $184: 206$ & 114:118 & 157:179 & 253:255 & 172:190 & 197:203 & 195 & 116:126:166 & 206:230:236 & $223: 225: 255$ & 119:157 & 185:197:207 \\
\hline Fertődi téli-P & $174: 208$ & $114: 130$ & $157: 175$ & 255 & $162: 168$ & $185: 197$ & $163: 173$ & 120:124 & 218:226 & $247: 255$ & 133:181 & 185:199 \\
\hline Fertődi téli-Sz. & 174:208 & 114:130 & $157: 175$ & 255 & 162:168 & 185:197 & 163:173 & 120:124 & 218:226 & $247: 255$ & 133:181 & 185:199 \\
\hline Florina & 184:208 & 116:130 & 145:175 & 243:247 & 162:190 & 197:199 & 173:197 & 120:124 & 228:232 & 211:229 & 119:145 & 185:207 \\
\hline Gala & 170:206 & 118:130 & 141:179 & 231:241 & 172:184 & 197:199 & 173 & 116:126 & 216:232 & $225: 255$ & 145:181 & 199:257 \\
\hline Gegesi piros & 180:182 & 118:130 & 141:175 & $231: 251$ & 162:192 & 197:211 & 177:207 & 126:166 & 232:236 & 217:225 & 121:133 & 185:259 \\
\hline Gomba Károly & 170:184 & 116:118 & 177:199 & $231: 243$ & 172:190 & 197:199 & 169:175 & 116:180 & 214:232 & $225: 247$ & 135:183 & 185:205 \\
\hline Gyógyi piros & 180:184 & 116:124 & 179:183 & $253: 255$ & 162:188 & 197:205 & $175: 213$ & 126:152 & $228: 232$ & $229: 255$ & 123:179 & 199:207 \\
\hline
\end{tabular}




\section{5. táblázat. (folyt.)}

\begin{tabular}{|c|c|c|c|c|c|c|c|c|c|c|c|c|}
\hline Fajta & CH01f02* & CH01h01* & CH02c02a & CH02c09* & CH05e03 & CH04e03 & CH05d11 & CH03g07 & CH02c11* & CH02d08* & CH03a02 & CH05c04 \\
\hline Harang alma & 170:208 & 114:118 & $157: 177$ & 243 & $162: 172$ & 197:201 & 169:177 & $126: 180$ & $222: 232$ & $225: 255$ & 183 & $185: 207$ \\
\hline Herceg Batthyányi & 180:182 & $116: 130$ & $127: 181$ & $243: 253$ & $162: 168$ & 195:199 & 175 & $116: 126$ & $206: 228$ & $229: 253$ & 123 & 185 \\
\hline Honti alma (A) & $170: 180$ & 114:118:130 & $141: 185$ & $231: 241: 243$ & 162 & 197:211 & 169:175:177 & $126: 166$ & $222: 232: 236$ & $217: 253$ & $135: 155$ & $185: 205: 259$ \\
\hline Honti alma (G) & $170: 180$ & 114:118:130 & $141: 185$ & $231: 241: 243$ & 162 & $197: 211$ & 169:175:177 & 126:166 & $222: 232: 236$ & $217: 253$ & $135: 155$ & $185: 205: 259$ \\
\hline Hosszúfalusi & 172:180 & 112:118 & 145:167 & 255 & 162 & 185:205 & 175 & 116 & $206: 236$ & $211: 217$ & 119:145 & $207: 257$ \\
\hline Húsvéti rozmaring & 170:184 & 112 & 171:185:191 & $243: 247: 253$ & $162: 172: 190$ & 193:197:203 & 187:195:205 & 116:124:126 & $222: 232$ & 211:217:247 & 135:145 & 185:207 \\
\hline Ízletes zöld & 172:182 & $128: 130$ & $167: 185$ & $231: 249$ & 164:192 & 187:209 & $175: 207$ & 118:126 & 232:236 & $211: 217$ & 121:145 & $257: 259$ \\
\hline Jászvadóka & $174: 202$ & 108:116 & 171 & $243: 247$ & 162 & $197: 203$ & 171:205 & 118:124 & 206 & $211: 247$ & 119:137 & 185 \\
\hline Jonathan & 208 & $114: 130$ & 175 & $247: 255$ & $162: 184$ & 187:197 & $173: 175$ & $116: 120$ & $226: 232$ & $229: 255$ & 119:133 & 185 \\
\hline Kanadai renet 1 & $184: 206$ & 104:126:130 & $167: 177: 181$ & $231: 247: 253$ & $164: 178: 198$ & 187:197:201 & $171: 175$ & 116:124:152 & 218:228:230 & 213:225:229 & $121: 137$ & 185 \\
\hline Kanadai renet 2 & 184:206 & 104:126:130 & 167:177:181 & $231: 247: 253$ & 164:178:198 & 187:197:201 & 171:175 & 116:124:152 & 218:228:230 & $213: 225: 229$ & 121:137 & 185 \\
\hline Kanadai renet 3 & 184:206 & 104:126:130 & 167:177:181 & $231: 247: 253$ & 164:178:198 & 187:197:201 & 171:175 & 116:124:152 & 218:228:230 & $213: 225: 229$ & 121:137 & 185 \\
\hline Királyi renet & $174: 180$ & 118:128 & 179 & $231: 241: 253$ & $162: 164$ & 197:205 & 177 & 116:120:178 & 206:224:230 & $225: 229$ & 119:139 & 185:205 \\
\hline Kisasszony & $170: 184$ & 114:118 & $127: 171$ & $231: 253$ & $162: 190$ & 193:209 & 169:205 & 126 & $206: 216$ & 211 & 119:135 & 199:207 \\
\hline Lóci cirmos alma & 180:190 & $112: 130$ & $145: 199$ & $243: 247$ & $146: 172$ & 197:199 & $171: 175$ & $126: 170$ & $206: 230$ & $217: 253$ & $135: 145$ & $257: 259$ \\
\hline Lóci édes almája & 182:184 & 114:116:130 & 171:179:203 & 253 & $162: 190$ & 193:197 & 169:187:195 & $116: 126$ & $214: 222$ & $225: 255$ & 119:137:155 & $187: 199$ \\
\hline Londoni pepin & 180:208 & 116:120 & $131: 183$ & 231:241 & 162 & 197:209 & 173 & 126 & 218:232 & 211 & 133:145 & 199:209 \\
\hline Marosszéki piros & 180:182 & 112:122 & 179 & $243: 251$ & $162: 190$ & 193:205 & 175:195 & 122:166 & 216 & 255 & 181 & 199:209 \\
\hline Masánszki & 170:172 & $114: 118$ & 175:179 & $241: 243$ & 160:172 & 197:223 & 177:199 & 124:180 & $232: 236$ & $211: 223$ & 145 & 207 \\
\hline Máté Dénes & 180:184 & $126: 144$ & 163 & $231: 247$ & $162: 172$ & 195:197 & 169 & 116 & $216: 226$ & $223: 225$ & $155: 179$ & $185: 199$ \\
\hline McIntosh & $174: 206$ & $114: 116$ & 179:183 & $231: 255$ & 162 & 185:199 & 173:175 & $126: 166$ & 226 & $211: 229$ & 119:157 & 207 \\
\hline Mosolygós batul & 190:210 & 114:118 & 167 & $243: 249$ & 164 & 197 & $177: 211$ & 116:180 & $234: 236$ & $211: 225$ & 119:135 & $207: 259$ \\
\hline Nemes sóvári & 180:184:206 & 116 & 141:149:179 & $231: 243: 255$ & 158:162:190 & 197:205 & 171:173:177 & $116: 120$ & $206: 218: 234$ & 211:213:247 & $135: 145$ & 185:199:207 \\
\hline $\begin{array}{l}\text { Nemes sóvári (Sóvári } \\
\text { nobil) }\end{array}$ & 170:208 & 114:118 & $157: 175$ & 243 & $162: 172$ & 197:201 & 169:177 & 126:180 & 220:230 & $225: 255$ & 135 & 185:207 \\
\hline Nemes szercsika & 170:208 & 112:114 & 145:177 & $239: 253$ & $158: 190$ & 197 & 169:195 & 124:166:180 & 206:216:232 & $223: 247$ & $133: 145$ & 199:259 \\
\hline Nyári fontos & 184:188 & 112:130 & 129:179 & 231:243:255 & 160:172 & 197:223 & 171:181:187 & $116: 126$ & 218:220:234 & $211: 225$ & 135:145 & 179:257 \\
\hline Ontario & $180: 182$ & $128: 130$ & 127:169 & $231: 243$ & $162: 198$ & 199:201 & $175: 197$ & $116: 120$ & $206: 228$ & $225: 249$ & $157: 181$ & $203: 259$ \\
\hline Orbai alma & 170:190:206 & 108:120:130 & $167: 179$ & $237: 251: 253$ & 172:178 & 187:197:201 & 171:187 & 120:166:176 & $214: 222$ & $211: 225: 255$ & 119:131:181 & 189:199:207 \\
\hline
\end{tabular}




\section{5. táblázat. (folyt.)}

\begin{tabular}{|c|c|c|c|c|c|c|c|c|c|c|c|c|}
\hline Fajta & CHO1f02* & CH01h01* & CH02c02a & CH02c09* & CH05e03 & CH04e03 & CH05d11 & CH03g07 & CH02c11* & CH02d08* & CH03a02 & CH05c04 \\
\hline Pinova & $170: 206$ & 118:130 & $157: 185$ & $241: 255$ & $172: 178$ & $187: 199$ & $171: 173$ & $126: 180$ & $226: 232$ & $217: 223$ & $133: 157$ & $185: 257$ \\
\hline Prima & 180:208 & 114:118 & 179 & $231: 241$ & 178:184 & $185: 205$ & $169: 173$ & 126:166 & $228: 232$ & $253: 255$ & $133: 157$ & $185: 209$ \\
\hline Sándor cár & 170:180:206 & 114:130 & 141:157:183 & $231: 249$ & $162: 172$ & 199:203 & 171:175 & $122: 126: 170$ & $206: 218: 226$ & $225: 227: 253$ & 119:133 & $185: 203$ \\
\hline Sárga szépvirágú & $174: 180$ & 116:130 & $157: 179$ & $231: 255$ & 168:184 & 185:197 & 169:173 & 116:124 & $218: 228$ & $223: 247$ & 119:181 & 185:199 \\
\hline Sikulai & 180:182 & 118:130 & $141: 175$ & $231: 251$ & $162: 192$ & $197: 211$ & 177:207 & $126: 166$ & $232: 236$ & $217: 225$ & $121: 133$ & $185: 259$ \\
\hline Simonffy piros & 170:206 & 118:142 & 181 & $231: 247$ & $160: 172$ & 197:201 & 171 & 126 & 206:218 & 255 & 135 & 185 \\
\hline Szabadkai szercsika & 170:202 & 108:114 & $153: 157: 185$ & $239: 243: 253$ & 170:188:190 & 195:197:203 & $177: 195: 207$ & 116:126:166 & $222: 226$ & $229: 255$ & 119:145 & 185:199 \\
\hline Szászpap alma & 170:180 & 112:116 & $167: 187$ & $231: 255$ & 162 & 197:205 & 175 & 116:120 & $206: 236$ & $211: 255$ & 119:145 & 207 \\
\hline Széchenyi renet & $184: 206$ & 118:130 & $157: 167$ & $231: 253$ & $172: 178$ & $197: 223$ & $171: 175$ & 126:152 & $206: 230$ & $213: 255$ & $121: 157$ & 185:199 \\
\hline Tartós Gusztáv & $186: 208$ & $114: 118$ & $183: 185$ & $241: 253$ & 180 & 199:211 & 171:195 & $116: 124$ & $214: 232$ & $225: 229$ & 123 & 257 \\
\hline Téli arany parmen $(\mathrm{P})$ & 184 & 112:128 & $127: 183$ & 253 & 162 & 197:199 & 169:175 & $126: 152$ & $216: 230$ & 229:255 & 119:135 & 185:209 \\
\hline Téli arany parmen $(\mathrm{Sz})$ & 184 & 112:128 & $127: 183$ & 253 & 162 & 197:199 & 169:175 & 126:152 & $216: 230$ & $229: 255$ & 119:135 & 185:209 \\
\hline Téli sóvári & 170:176 & 114:118 & 171 & 231:247 & 172:190 & 199:205 & 175:177 & 116:124 & 228:232 & $225: 255$ & 137:179 & $185: 207$ \\
\hline Tordai alma & 184:188 & 112:130 & 129:179 & $231: 243: 255$ & 160:172 & $197: 223$ & 171:181:187 & 116:126 & 218:220:234 & 211:225 & 135:145 & $179: 257$ \\
\hline Tordai piros kálvil & 180:188 & 104:118 & 127 & $231: 243$ & 162 & 199 & 171 & 120:176 & 206 & 211 & 133:179 & $185: 207$ \\
\hline Török Bálint (T) & 170:180 & 112:116 & 129:157 & 231:239 & 162:172 & 197:205 & $175: 187$ & $120: 126$ & 216:220 & $211: 217$ & 135 & 179:207 \\
\hline Török Bálint (Ú) & 170:180 & 112:116 & 129:157 & $231: 239$ & 162:172 & 197:205 & $175: 187$ & 120:126 & $216: 220$ & 211:217 & 135 & 179:207 \\
\hline Tükör alma & 182:208 & 118:130 & 175:191 & $241: 255$ & 162:170 & 187:197 & 169 & 116:124 & $206: 226$ & $207: 255$ & 119:157 & $185: 207$ \\
\hline Vajki alma & 170:180:206 & 114:130 & $141: 157: 183$ & $231: 249$ & $162: 172$ & 199:203 & $171: 175$ & 122:126:170 & 206:218:226 & $225: 255$ & 119:133 & $185: 203$ \\
\hline Vilmos renet & 170:208 & 114:118 & $157: 177$ & 243 & $162: 172$ & 197:201 & 169:177 & 126:180 & 220:230 & 225 & 135:181 & $185: 207$ \\
\hline Zöld batul & 174:208 & 116:130 & 157 & $231: 247$ & 162 & 197:203 & 173 & 122:126 & 230 & 211:255 & 133:181 & 199:207 \\
\hline Zöld sóvári & 184:190 & 112:118 & $175: 185$ & 251 & 190 & 197:201 & $177: 181$ & $124: 126$ & $220: 230$ & $225: 255$ & $135: 145$ & 185:207 \\
\hline
\end{tabular}




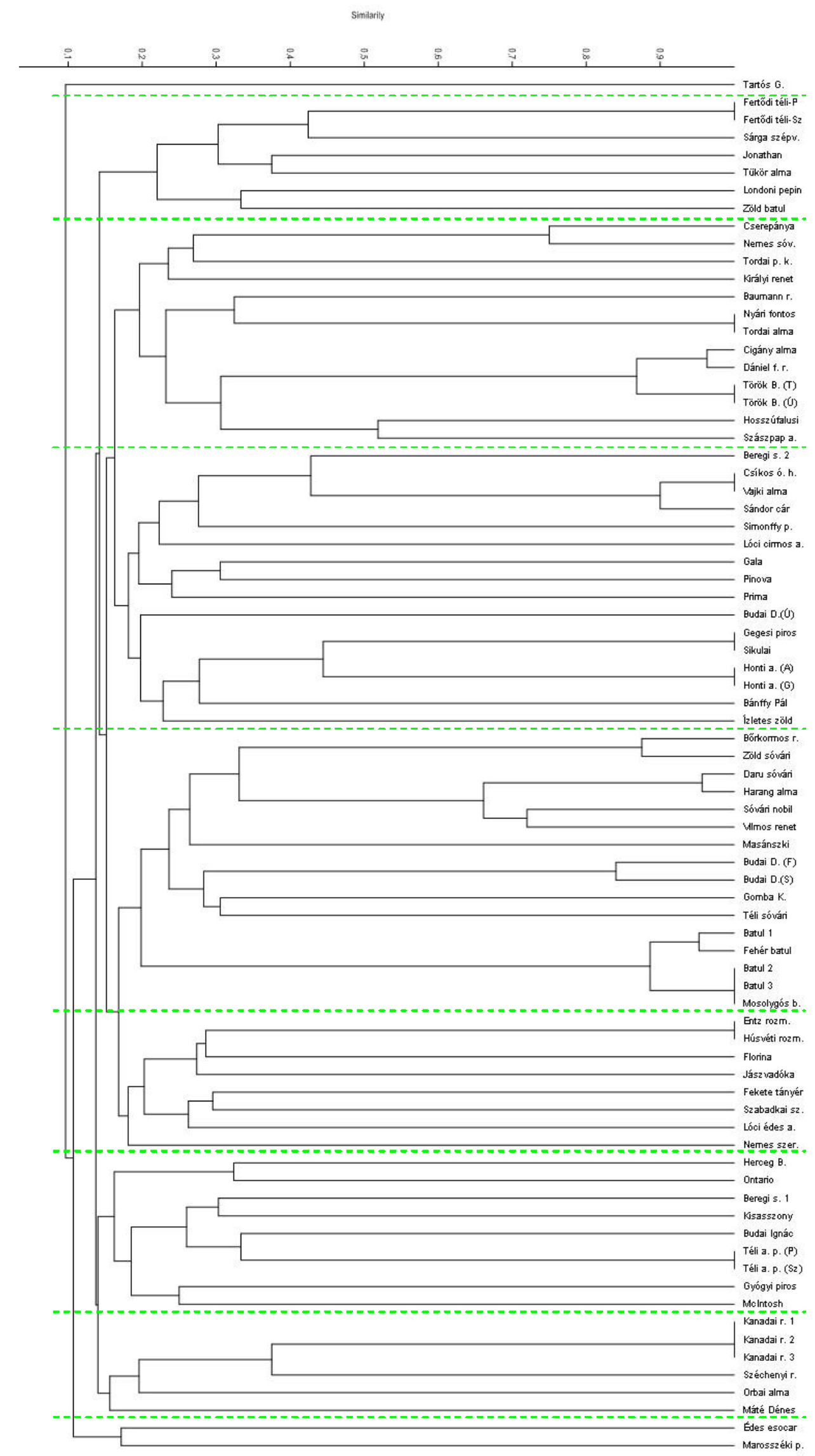

18. ábra. A fajták rokonsági viszonyai az SSR fragmentumok Jaccard-indexén alapuló genetikai távolság mátrix alapján. 
A Sóvári fajtákat a legtöbb irodalom a 'Közönséges sóvári' fajta változataként ismerteti. Az SSR vizsgálatba hét Sóvári genotípust vontunk be. Az allélösszetételük alapján még feltételezhető a rokonságuk, hiszen néhány lókuszon néhány fajtapár között találunk azonos allélokat, de ez inkább csak távoli rokonságra, és nem közvetlen leszármazásra enged következtetni. A dendrogramon elfoglalt helyzetük alapján a 'Sóvári nobil' és a 'Daru sóvári' áll legközelebb egymáshoz, de ez a távolság is viszonylag nagy, tehát nem jelenthető ki egyértelműen a rokonság. Ugyanebbe a főklaszterbe került a 'Téli sóvári' és a 'Zöld sóvári' is, de a távolság itt is nagyon nagy. Ettől eltérő két külön főklaszterbe került a 'Nemes sóvári' és a 'Beregi sóvári' két genotípusa. A szinonimának tartott 'Nemes sóvári' és 'Sóvári nobil' - a morfológiai eredményekhez hasonlóan - nem tekinthető azonos fajtának. A 'Beregi sóvári’ két vizsgált típusa igen nagy genetikai távolságot mutatott a dendrogramon, annak ellenére, hogy hat lókuszon egy-egy közös allélt találtunk, tehát a két vizsgált egyed nem azonos.

A szinonimaként ismert 'Cigány alma' és 'Simonffy piros' már a morfológiai vizsgálatok alapján is egyértelmüen elkülöníthető volt egymástól, amit a markeranalízis is alátámasztott. A szintén sokak által szinonimaként ismert 'Entz rozmaring', 'Húsvéti rozmaring', 'Honti alma' hármas közül az 'Entz rozmaring' és a 'Húsvéti rozmaring' genetikai ujjlenyomata $100 \%$-ban megegyezett. A 'Honti alma' 10 lókusz egy-egy allélja mutatott azonosságot a másik két fajtával, ezért vélhetően szülö-utód, vagy testvéri rokonságban vannak (ezt a dendrogram nem tükrözi), de a 'Honti alma' nem szinonimája egyik vizsgálta rozmaringnak sem. A hasonló morfológiai bélyegekkel rendelkező 'Nyári fontos’ és ‘Tordai alma’ páros allélösszetétele 100 \%-os egyezést mutatott.

Az SSR adatok kielemzésekor (mind az Identity, mind a dendrogram alapján) felfigyeltünk két meglepő egyezőségre. A 'Gegesi piros' és 'Sikulai', valamint a 'Csíkos óriás halasi' és 'Vajki alma' párosok az összes lókuszon 100 \%-os egyezést mutattak. Ezt az egyezést viszont a morfológiai vizsgálatok nem támasztották alá.

A mikroszatellit ujjlenyomatok a genotípusok nagy genetikai diverzitását mutatják. A dendrogramon is jól látható, hogy az azonos fajtákon, és a 'Batul' fajtákon kívül az összes fajta távol helyezkedik el egymástól. Csak néhány esetben találtunk 80\%-nál nagyobb egyezést. A felhasznált alma mikroszatellit primerek - a rügymutációval keletkezett fajták kivételével - minden esetben alkalmasnak bizonyultak a vizsgált fajták egyedi DNSprofiljának felállításához, mindazonáltal érdekes egyezésekre is felhívták a figyelmet. 


\subsubsection{SSR-en alapuló szülőazonosítás}

A régi fajták származására vonatkozóan nagyon kevés információ található a szakirodalomban, ami föként abból adódik, hogy ezek a régi fajták gyakran magról keletkeztek, nem irányított keresztezésekből. A vizsgált régi magyar fajták közül csak a 'Budai Domokos' ('Téli arany parmen’ × 'Jászvadóka'), és a kevésbé régi, de mai értelmezésben mégis nosztalgiafajtának számító 'Fertődi téli' ('Jonathan' × 'Török Bálint') származására találtunk pontos leírást (Angyal 1926).

A 'Fertődi téli', a 'Téli arany parmen' és a ‘Török Bálint' két-két különböző helyről begyüjtött mintája megegyezik, így csak az egyiket használtuk a további adatelemzések során. A 'Fertődi téli' fajtát a nemesítő, id. Porpáczy Aladár a 'Jonathan' × 'Török Bálint' keresztezésével állította elő. A vizsgálataink alapján a 'Jonathan' valóban lehetséges szülő (allélegyezőség mértéke: 100 \%), viszont a 'Török Bálint' nem lehet szülőfajta (26. táblázat). A két termőhelyről begyüjtött és tesztelt 'Török Bálint' és 'Fertődi téli' minták egyezése kizárja a fajtakeveredés lehetőségét. A 'Fertődi téli' fajtát eredményező magonc vagy szabadmegporzásból származik, vagy a polleneket felcserélték a keresztezés során, tehát a jövőben az apai fajtát ismeretlenként kell kezelni.

26. táblázat. A Fertődi téli és feltételezett szülőfajtáinak allélösszetétele (az allélok feltételezett származását színnel jelöltük)

\begin{tabular}{lccc}
\hline Primer & $\begin{array}{c}\text { Fertódi téli } \\
\text { (utód) }\end{array}$ & $\begin{array}{c}\text { Jonathan } \\
(+)\end{array}$ & $\begin{array}{c}\text { Török Bálint } \\
\left({ }^{đ}\right)\end{array}$ \\
\hline CH01f02 & $174: 208$ & 208 & $170: 180$ \\
CH01h01 & $114: 130$ & $114: 130$ & $112: 116$ \\
CH02c02a & $157: 175$ & 175 & $129: 157$ \\
CH02c09 & $255: 255$ & $247: 255$ & $231: 239$ \\
CH05e03 & $162: 168$ & $162: 184$ & $162: 172$ \\
CH04e03 & $185: 197$ & $187: 197$ & $197: 205$ \\
CH05d11 & $163: 173$ & $173: 175$ & $175: 187$ \\
CH03g07 & $120: 124$ & $116: 120$ & $120: 126$ \\
CH02c11 & $218: 226$ & $226: 232$ & $216: 220$ \\
CH02d08 & $247: 255$ & $229: 255$ & $211: 217$ \\
CH03a02 & $133: 181$ & $119: 133$ & 135 \\
CH05c04 & $185: 199$ & $185: 185$ & $179: 207$ \\
\hline
\end{tabular}

A 'Budai Domokos' fajta Erdélyből származik, nemesítője Budai József. A feljegyzések szerint a 'Téli arany parmen' × 'Jászvadóka' keresztezésből származik. A markeranalízis során a soroksári gyüjteményünkben megtalálható ‘Budai Domokos’ mintáját használva azt tapasztaltuk, hogy a nemesítő által megadott anya és apa sem lehet a szülő, mert az allélegyezés mértéke 41, ill. $16 \%$ volt (27. táblázat). Ekkor a 'Téli arany parmen'ből újabb mintát szereztünk be Pölöskéről, aminek az SSR ujjlenyomata azonosnak mutatkozott a korábban használt mintáéval, így fajtaazonosnak tekintettük. A 'Jászvadóka'- 
ból sajnos nem sikerült másik mintát szerezni, így ennek fajtaazonosságát nem tudtuk ellenőrizni, de a szakirodalmi leírás (Bereczki 1882) alapján vélhetően fajtaazonos. A szülők fajtakeveredéséből származó hibát a 'Téli arany parmen' esetében kizártuk, és ugyanez feltételezhető a 'Jászvadóka'-nál is, így a továbbiakban szükségessé vált a 'Budai Domokos' fajtaazonosságának ellenőrzése.

27. táblázat. A soroksári génbankban megtalálható Budai Domokos és feltételezett szülöfajtáinak allélösszetétele (az allélok feltételezett származását színnel jelöltük)

\begin{tabular}{lccc}
\hline Primer & $\begin{array}{c}\text { Budai Domokos } \\
\text { (Soroksár) } \\
\text { (utód) }\end{array}$ & $\begin{array}{c}\text { Téli arany } \\
\text { parmen } \\
(+)\end{array}$ & $\begin{array}{c}\text { Jászvadóka } \\
(\text { đ) }\end{array}$ \\
\hline CH01f02 & $170: 208$ & $184: 184$ & $174: 202$ \\
CH01h01 & $118: 130$ & $112: 128$ & $108: 116$ \\
CH02c02a & $175: 185$ & $127: 183$ & $171: 171$ \\
CH02c09 & $231: 247$ & $253: 253$ & $243: 247$ \\
CH05e03 & $164: 184$ & $162: 162$ & $162: 162$ \\
CH04e03 & $197: 203$ & $197: 199$ & $197: 203$ \\
CH05d11 & $169: 175$ & $169: 175$ & $171: 205$ \\
CH03g07 & $116: 120$ & $126: 152$ & $118: 124$ \\
CH02c11 & $228: 232$ & $216: 230$ & $206: 206$ \\
CH02d08 & $217: 255$ & $229: 255$ & $211: 247$ \\
CH03a02 & $135: 135$ & $119: 135$ & $119: 137$ \\
CH05c04 & $185: 207$ & $185: 209$ & $185: 185$ \\
\hline
\end{tabular}

Az Újfehértói Génbankból beszereztük a ‘Budai Domokos’ gyümölcs- és levélmintáit. Ugyan még nem a teljes érés állapotában voltak a gyümölcsök, így a színeződés még nem alakult ki, de az alakból arra következtettünk, hogy nem azonos a soroksári gyüjteményben megőrzött fajtával. A soroksári és az újfehértói 'Budai Domokos' minta az SSR ujjlenyomatuk alapján sem tekinthető azonosnak. Az újfehértói 'Budai Domokos' minta pedigré vizsgálata azt mutatta, hogy az allélegyezőség mértéke a feltételezett szülőkkel $75 \%$, ill. 25 \%. Bár a 'Téli arany parmen' alléljaival egyezés ebben az esetben nagyobb volt, mint a soroksári minta esetében, de nem 100 \%, így a nemesítő által közölt származást nem tudtuk bizonyítani (28. táblázat).

A ‘Budai Domokos’ morfológiai leírása és rajza (Angyal 1926, Brózik és Régius 1957) szerint a soroksári genotípus fajtaazonosnak tünik, de a soroksári és az újfehértói egyedek fajtaazonosságának tisztázása érdekében a jövőben célszerü lenne a további genetikai vizsgálatokhoz Erdélyből, a bodosi Egyed Dániel-féle kertben álló, a keresztezésből származó anyafáról mintát gyüjteni. 
28. táblázat. Az újfehértói génbankban megtalálható Budai Domokos és feltételezett szülöfajtáinak allélösszetétele (az allélok feltételezett származását színnel jelöltük)

\begin{tabular}{lccc}
\hline Primer & $\begin{array}{c}\text { Budai Domokos } \\
\text { (Újjfehértó) } \\
\text { (utód) }\end{array}$ & $\begin{array}{c}\text { Téli arany } \\
\text { parmen } \\
(\text { ○) }\end{array}$ & $\begin{array}{c}\text { Jászvadóka } \\
(\text { đ) }\end{array}$ \\
\hline CH01f02 & $170: 182$ & $184: 184$ & $174: 202$ \\
CH01h01 & $112: 116$ & $112: 128$ & $108: 116$ \\
CH02c02a & $157: 183$ & $127: 183$ & $171: 171$ \\
CH02c09 & $253: 253$ & $253: 253$ & $243: 247$ \\
CH05e03 & $162: 192$ & $162: 162$ & $162: 162$ \\
CH04e03 & $187: 197$ & $197: 199$ & $197: 203$ \\
CH05d11 & $181: 181$ & $169: 175$ & $171: 205$ \\
CH03g07 & $118: 126$ & $126: 152$ & $118: 124$ \\
CH02c11 & $224: 230$ & $216: 230$ & $206: 206$ \\
CH02d08 & $217: 217$ & $229: 255$ & $211: 247$ \\
CH03a02 & $121: 135$ & $119: 135$ & $119: 137$ \\
CH05c04 & $185: 185$ & $185: 209$ & $185: 185$ \\
\hline
\end{tabular}

Az Identity program az adatok elemzésekor elkészíti a lehetséges szülő-utód kombinációkat is. Az értékelés során két lehetséges származásra irányította rá a figyelmet, amelyeknek szakirodalom szerinti megalapozottsága nincs, de érdemes figyelembe venni:

'Harang alma' = 'Daru sóvári' $\times$ 'Gomba Károly'

'Daru sóvári' = 'Gomba Károly' × 'Harang alma'

A 'Daru sóvári' és a 'Harang alma' között csak egyetlen allélban van különbség, ezért szerepelhet szülőként, és a másik kombinációban utódként. A 29. táblázatban az egyik lehetséges változatot szemléltetjük.

29. táblázat. A Daru sóvári, Harang alma és a Gomba Károly fajták lehetséges rokoni viszonyai az allélösszetételük miatt (az allélok feltételezett származását színnel jelöltük)

\begin{tabular}{|c|c|c|c|}
\hline Primer & $\begin{array}{c}\text { Harang alma } \\
\text { (utód) }\end{array}$ & $\begin{array}{c}\text { Daru sóvári } \\
\left(()_{)}\right)\end{array}$ & $\begin{array}{c}\text { Gomba Károly } \\
\left(\varrho^{\lambda}\right)\end{array}$ \\
\hline CH01f02 & 170:208 & 170:208 & 170:184 \\
\hline CH01h01 & 114:118 & 114:118 & 116:118 \\
\hline $\mathrm{CH} 02 \mathrm{c} 02 \mathrm{a}$ & 157:177 & 157:177 & 177:199 \\
\hline $\mathrm{CH} 02 \mathrm{c} 09$ & 243:243 & 243:243 & 231:243 \\
\hline $\mathrm{CH} 05 \mathrm{e} 03$ & 162:172 & 162:172 & 172:190 \\
\hline $\mathrm{CH} 04 \mathrm{e} 03$ & 197:201 & 197:201 & 197:199 \\
\hline CH05d11 & 169:177 & 169:177 & 169:175 \\
\hline $\mathrm{CH} 03 \mathrm{~g} 07$ & 126:180 & 126:180 & 116:180 \\
\hline $\mathrm{CH} 02 \mathrm{c} 11$ & 222:232 & 222:232 & 214:232 \\
\hline $\mathrm{CH} 02 \mathrm{~d} 08$ & $225: 255$ & $225: 255$ & 225:247 \\
\hline $\mathrm{CH} 03 \mathrm{a} 02$ & 183:183 & $135: 183$ & 135:183 \\
\hline $\mathrm{CH} 05 \mathrm{c} 04$ & 185:207 & $185: 207$ & $185: 205$ \\
\hline
\end{tabular}




\subsubsection{Korreláció a morfológia és a molekuláris vizsgálat között}

A morfológiai (UPOV) adatokból készített mátrix (․ melléklet) és az SSR adatokból

Jaccard-indexen alapuló genetikai távolság mátrix (9. melléklet) közötti összefüggés bizonyítása érdekében Mantel-tesztet végeztünk. A Mantel-teszt szignifikáns, közepes erősségü korrelációt $(r=0,33343, p=0,00000)$ mutatott ki a morfológiai és a molekuláris eredmények között. 


\section{EREDMÉNYEK MEGVITATÁSA ÉS KÖVETKEZETÉSEK}

\subsection{Virágzásfenológia}

Virágzásfenológiai megfigyeléseinkben 57 fajtát vizsgáltunk. Ezek közül csak kevés fajta virágzási sajátosságaival találkozhatunk a szakirodalomban. Soltész (1982) megfigyelései szerint a rügymutációval keletkezett fajták virágzásának kezdete között csak 1-2 nap eltérés van, amit mi is tapasztaltunk a Batul fajtacsoportba tartozó fajták esetében. Brózik és Nyéki (1975) szerint minél korábban kezdődik a virágzás, annál tovább tart, de ezzel a megállapítással Soltész (1996) nem ért egyet. A korai virágzáskezdet virágzástartamra való hatását mi is tapasztaltuk a 2007 és 2008 években, amikor a virágzás időszaka 5-12 nappal hosszabb volt, mint a 2009-2011 években, amikor 4-10 nappal később kezdődött a virágzás.

A Brózik és Nyéki (1975) és Soltész (1992) által ismertetett virágzási időt befolyásoló tényezők közül az időjárást a kísérlet rövidebb (5 év) időtartama miatt nem tudjuk értékelni, csak feltételezni tudjuk a hatását. Viszont a virágberakódottságnak a virágzás tartamát befolyásoló hatása jól megfigyelhető volt pl. a ‘Cigány alma', 'Gegesi piros’, ‘Gyógyi piros’, 'Ízletes zöld' és a 'Tordai alma' esetében, ahol a gyenge-közepes virágberakódottságból kifolyólag igen rövid, 4-6 napos virágzási időtartamot tapasztaltunk.

A szakirodalom (Soltész 1996, 2002) szerint a fővirágzás szerinti relatív virágzási sorrend ugyanolyan instabil, mint a virágzás kezdete szerinti besorolás, és a különböző években sem tapasztalható azonos sorrend. Soltész (1992) szerint a 'Batul' és 'Nyári fontos' labilis, a 'Húsvéti rozmaring' stabil, míg a 'Londoni pepin' nagyon stabil virágzási idejü. 5 éves vizsgálatainkban a fajták stabilitását nem tudjuk pontosan megadni, de annyit meg tudtunk állapítani, hogy az igen korai, korai és az igen kései virágzású fajták stabil virágzási idejünek tekinthetők, viszont a középidejü és a kései virágzású fajták többségénél további vizsgálati évek szükségesek a pontos csoportba soroláshoz.

Az egyes fajták relatív virágzási ideje alapján virágzásiidő-csoportokba sorolhatjuk a fajtákat. A Bodor et al. (2008) által kontrolként javasolt igen korai virágzású 'Reglindis' vizsgálatainkban is minden évben stabilan a legkorábban virágzó fajták közé tartozott. Mivel a különböző szakirodalmak nem egységesek abban a tekintetben, hogy melyiket javasolják figyelembe venni a fajtatársításnál, elkészítettük a virágzás kezdete és fővirágzás szerinti csoportosítást is. Soltész (1996) szerint a fővirágzás alapján kialakított csoportosítás sokkal informatívabb, és gyakrabban alkalmazzák. A szakirodalommal összevetést nehezíti, hogy gyakran nem közlik, hogy melyik időpont alapján történt a virágzási időcsoportba sorolás, továbbá különböző számú (3-6) csoportot alakítanak ki. A gyümölcstermesztés gyakorlatában a fajtákat a fő virágzási idejük alapján három (korai, közepes és késői) 
virágzásiidő-csoportokba sorolják (Brózik és Nyéki 1974). Soltész (1992) hat (nagyon korai, korai, középkorai, középkései, kései és nagyon kései) virágzási csoportot alkalmaz. Brózik és Régius (1957) és az UPOV (2005) irányelvei szerint a virágzás kezdete alapján öt csoportba sorolhatjuk a fajtákat: nagyon korai, korai, közepes, kései és nagyon kései.

Soltész (1996) megadja a virágzás kezdetét és a fővirágzást is, de a fővirágzás alapján való csoportosítást javasolja. Ezzel szemben Brózik és Régius (1957) az átlagos virágzás kezdetének ideje szerint határozza meg a csoportokat. A mi megfigyeléseinkben az igen korai és az igen kései virágzású fajták mind a virágzás kezdete, mind pedig a fővirágzás alapján azonos csoportba sorolhatók, míg jelentős eltérés figyelhető meg a közepes és a kései virágzású fajtáknál.

Brózik (in Brózik és Nyéki 1975) adatai szerint a 'Simonffy piros’ korai virágzású, de a mi vizsgálatainkban a virágzás kezdete alapján kései, a fővirágzás alapján közepes virágzású volt. Brózik (in Brózik és Nyéki 1975), Bödecs és Tomcsányi (1979), valamint Soltész (1982) a 'Húsvéti rozmaring'-ot középidőben virágzónak írja le. Mi nem vizsgáltuk ezt a fajtát, csak az 'Entz rozmaring'-ot, amelyet mi is középidőben virágzónak találtuk mind a virágzás kezdete, mind a fővirágzás szerint. A 'Budai Domokos' és a 'Londoni pepin' késői, a 'Sárga szépvirágú' közepes virágzási idejü, ami megegyezik a Brózik és Soltész által közölttel, de Bödecs és Tomcsányi (1979) szerint a 'Londoni pepin’ középkorai virágzású.

A fajták virágzási idejének jellemzőit csak több év vizsgálata alapján tisztázhatjuk megnyugtatóan, ezért az eredményeink alapján ismertetett virágzási időcsoportokat csak tájékoztató jellegünek kell tekinteni.

\subsection{Markeranalízis}

\subsubsection{SSR polimorfizmus}

Vizsgálatainkban a 12 SSR lókuszban kapott átlagos allélszám 13,33 volt, ami hasonló számos kutató (Hokanson et al. 1998, Guarino et al. 2006, Wichmann et al. 2007, Laurens et al. 2004, Pereira-Lorenzo et al. 2007, Bassil et al. 2009) génbankokban megtalálható fajták variabilitásának vizsgálatakor kapott adataihoz. Szintén fajtagyüjtemények variabilitásának felmérésekor Garkava-Gustavsson et al. (2008), Gasi et al. (2010) ennél kicsit kevesebb, 10,4 átlagos allélszámot kapott. Viszont számos kutató (Guilford et al. 1997, Liebhard et al. 2002) jóval kisebb átlagos allélszámot (4-6) mutattak ki, ami annak köszönhető, hogy kevesebb fajtát vizsgáltak. Ugyanis ők 8-20, főként modern árufajtával dolgoztak, míg a korábban

idézett kutatók minimum 40, és főként helyi tájfajta bevonásával végezték a diverzitásvizsgálatokat, ami felhívja a figyelmet a tájfajták szerepére a genetikai variabilitás 
megőrzése, illetve szélesítése érdekében. Meglepően kis átlagos allélszámot $(2,8)$ detektáltak Farrokhi et al. (2011) 44 iráni fajta 16 SSR marker használatával. Ezt az elválasztási technikával magyarázzák, ugyanis a nagy elválasztóképességü poliakrilamid helyett agaróz gélen választották el a fragmentumokat. Saját eredményünknél jóval nagyobb $(16,5-18,5)$ átlagos allélszámot tapasztalt van Treuren et al. (2010), Gharghani et al. (2009), Urbanovich és Kazlovskaya (2009), viszont ők igen nagy mintaszámmal (500, 160, 110 fajta, ill. genotípus) dolgoztak.

A 30. táblázatban összevetjük a saját vizsgálatainkban kapott lókuszonkénti allélszámokat és allélméret tartományokat néhány szakirodalmi adattal. Az allélméret tartományban nem találtunk kiemelkedően eltérő értékeket más kutatók eredményeihez képest. A vizsgálatainkban szereplő lókuszokon kapott allélszámok - Liebhard et al. (2002) és Potts et al. (2012) adatait leszámítva - hasonlóak a korábban publikáltakhoz. Liebhard et al. (2002) adatai valószínúleg azért kisebbek, mert - mint azt korábban már megjegyeztük csak 8 világfajtát vizsgáltak. Potts et al. (2012) 164 Malus faj, fajta és hibrid bevonásával végezte a vizsgálatait, így a kis allélszámot a vizsgált genotípusok kisebb változatossága eredményezhette. Van Treuren et al. (2010) igen nagy (19-37) allélszámot detektált - a Potts et al. (2012) által használt markerekkel is -, ami a nagyobb variabilitással rendelkező minták eredménye.

A cikkekben nem minden szerző tünteteti fel a várt és a megfigyelt heterozigótaságot.

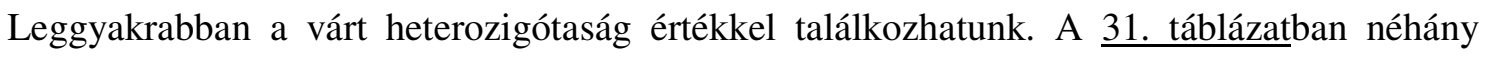
szakirodalomban fellelhető, általunk is vizsgált lókusz várt és megfigyelt heterozigótaság értékeit mutatjuk be. A saját adataink alapján a várt heterozigótaság (He) 0,77 és 0,91 között mozgott (átlag: 0,85), ami hasonló Rouston et al. (2009) és Sikorskaite et al. (2012) által közölt eredményekhez $(\mathrm{He}=0,75-0,86$, ill. 0,73-0,88). Más kutatók (pl. Garkava-Gustavsson et al. 2008) fajtagyüjteményben végzett vizsgálatai hasonló várt heterozigótaság átlagot $(0,74)$ eredményeztek, de a mérési tartomány jóval szélesebb volt $(\mathrm{He}=0,36-0,88)$, ami az igen különböző lókuszonkénti allélszámból (2-15 allél/lókusz) adódik. Mivel a heterozigótaság értéke az allélok számával és gyakoriságával van összefüggésben, így a kevesebb génváltozattal rendelkező fajták vizsgálatakor kisebb heterozigótaság érték várható, mint azt Liebhard et al. (2002) és Potts et al. (2012) adatai is mutatják. 
30. táblázat. A vizsgált lókuszokon kapott allélszámok és allélméret tartományok a szakirodalomban (*=ECPGR által kijelölt primer)

\begin{tabular}{|c|c|c|c|c|c|c|c|c|c|c|c|c|c|c|c|c|c|c|c|c|}
\hline \multirow[b]{2}{*}{$\stackrel{\Xi}{\Xi}$} & \multicolumn{2}{|r|}{ 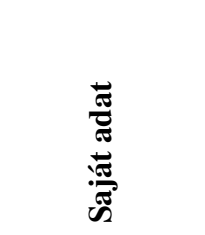 } & \multicolumn{2}{|c|}{ 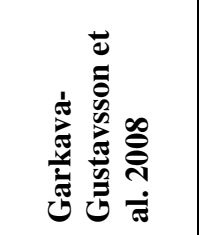 } & \multicolumn{2}{|r|}{ 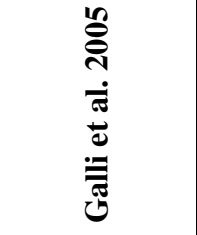 } & \multicolumn{2}{|r|}{ 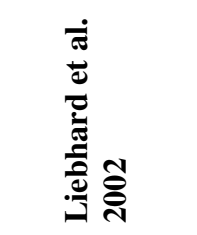 } & \multicolumn{2}{|r|}{ 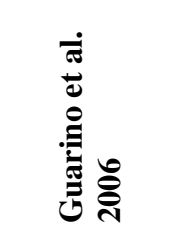 } & \multicolumn{2}{|r|}{ 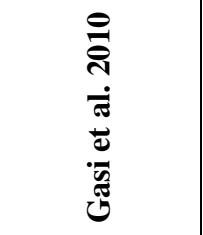 } & \multicolumn{2}{|r|}{ 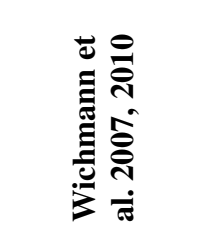 } & \multicolumn{2}{|r|}{ 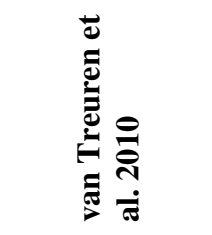 } & \multicolumn{2}{|r|}{ 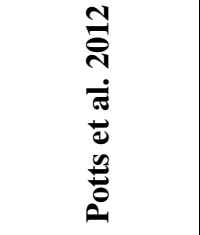 } & \multicolumn{2}{|c|}{ 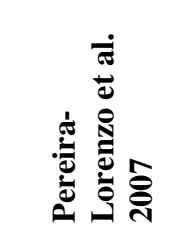 } \\
\hline & 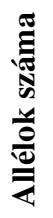 & 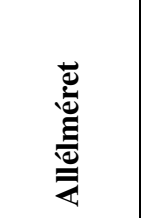 & 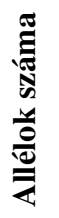 & 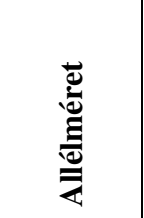 & 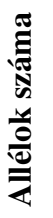 & & 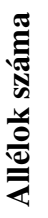 & 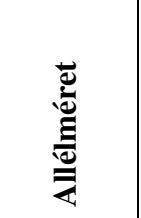 & 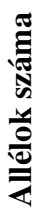 & & 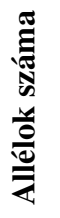 & 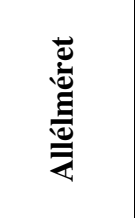 & 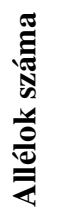 & 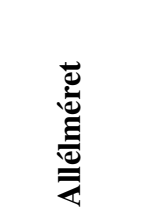 & 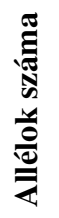 & 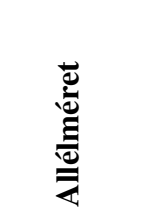 & 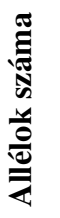 & 总 & 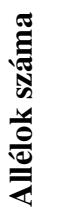 & 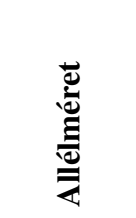 \\
\hline $\mathrm{CH} 01 \mathrm{f0} 2 *$ & 15 & $170-212$ & & & & & 7 & $174-206$ & & & & & & & & & 7 & $174-206$ & & \\
\hline CH01h01* & 15 & $104-144$ & & & & & 6 & $114-134$ & & & 9 & $111-145$ & & & 19 & $94-149$ & 6 & $114-134$ & & \\
\hline $\mathrm{CH} 02 \mathrm{c} 02 \mathrm{a}$ & 19 & $127-199$ & & & & & 9 & $129-176$ & & & 17 & $130-192$ & & & 35 & $137-219$ & & & & \\
\hline $\mathrm{CH} 02 \mathrm{c} 09^{*}$ & 10 & $231-255$ & 10 & $231-255$ & & & 6 & $233-257$ & 9 & $226-259$ & & & 11 & $229-257$ & & & 6 & $233-257$ & & \\
\hline $\mathrm{CH} 05 \mathrm{e} 03$ & 14 & $146-198$ & & & 13 & $160-193$ & 10 & $158-190$ & & & 13 & $153-193$ & 15 & $149-193$ & 37 & $140-216$ & & & & \\
\hline $\mathrm{CH} 04 \mathrm{e} 03$ & 12 & $185-223$ & & & 12 & $178-222$ & 11 & $179-222$ & & & & & 13 & $161-222$ & & & & & & \\
\hline CH05d11 & 15 & $163-213$ & & & 10 & $169-211$ & 5 & $171-211$ & & & & & 12 & $169-227$ & & & & & & \\
\hline $\mathrm{CH} 03 \mathrm{~g} 07$ & 12 & $116-180$ & & & 7 & $119-179$ & 5 & 119-181 & & & & & 8 & $119-179$ & & & & & 12 & 119-179 \\
\hline $\mathrm{CH} 02 \mathrm{c} 11 *$ & 13 & $206-236$ & 12 & $206-236$ & & & 7 & 219-239 & 11 & $209-240$ & & & 8 & $206-228$ & & & 7 & 219-239 & & \\
\hline $\mathrm{CH} 02 \mathrm{~d} 08 *$ & 12 & $207-255$ & 13 & $205-254$ & & & 7 & $210-254$ & 12 & $210-256$ & 11 & $212-254$ & 7 & $209-229$ & 23 & $212-266$ & 7 & $210-254$ & 13 & $206-254$ \\
\hline $\mathrm{CH} 03 \mathrm{aO} 2$ & 12 & $119-183$ & & & & & 9 & $124-184$ & & & & & & & & & & & & \\
\hline $\mathrm{CH} 05 \mathrm{c} 04$ & 11 & $179-259$ & & & & & 7 & $186-258$ & & & & & & & & & & & & \\
\hline $\begin{array}{l}\text { Vizsgált } \\
\text { fajtaszám }\end{array}$ & & 55 & & 68 & & 66 & & 8 & & 56 & & 39 & & 40 & & 695 & & 164 & & 140 \\
\hline
\end{tabular}


Vizsgálatainkban a megfigyelt heterozigótaság (Ho) 0,63 és 0,98 között mozgott (átlag: 0,83), ami hasonló Sikorskaite et al. (2012) $(\mathrm{Ho=0,84)}$ és Pereira-Lorenzo et al. (2007) $(\mathrm{Ho}=0,83)$ eredményeihez, és nagyobb, mint a Guilford et al. (1998) $(\mathrm{Ho}=0,69)$ és Bassil et al. (2009) $(\mathrm{Ho=}=0,76)$ által közölt adatok. Guarino et al. (2006) eredményeihez hasonlóan a megfigyelt heterozigótaság öt vizsgált lókusz esetében kicsit kisebb volt, mint a várt heterozigótaság (He-Ho különbség=0,1-0,2). Garghani et al. (2009) jelentős különbséget tapasztalt a várt és a megfigyelt heterozigótasági érték között az összes lókusz átlagában $(\mathrm{He}=0,83, \mathrm{Ho}=0,63)$, és az egyes lókuszokon (pl. CH05e03: He=0,86, Ho=0,45).

31. Táblázat. A vizsgált lókuszok várt (He) és megfigyelt (Ho) heterozigótaság értéke a szakirodalomban $(*=$ ECPGR által kijelölt primer)

\begin{tabular}{|c|c|c|c|c|c|c|c|c|c|c|c|}
\hline \multirow[t]{2}{*}{ 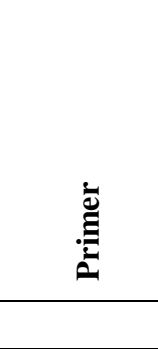 } & \multicolumn{2}{|c|}{ 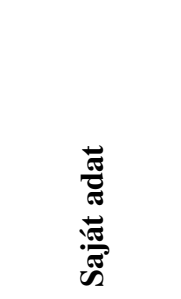 } & \multirow[t]{2}{*}{ 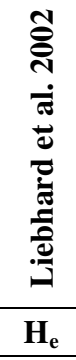 } & \multirow[t]{2}{*}{ 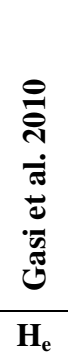 } & \multirow[t]{2}{*}{ 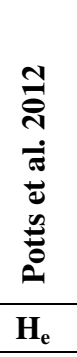 } & \multicolumn{2}{|c|}{ 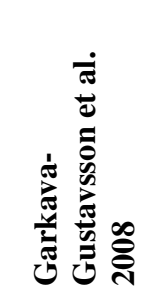 } & \multicolumn{2}{|c|}{ 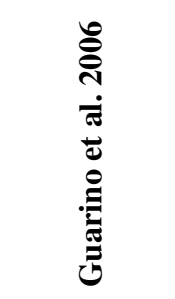 } & \multicolumn{2}{|c|}{ 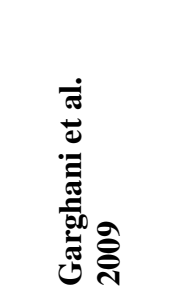 } \\
\hline & $\mathbf{H}_{\mathrm{e}}$ & $\mathbf{H}_{\mathbf{o}}$ & & & & $\mathbf{H}_{\mathbf{e}}$ & $\mathbf{H}_{\mathbf{o}}$ & $\mathbf{H}_{\mathrm{e}}$ & $\mathbf{H}_{\mathbf{o}}$ & $\mathbf{H}_{\mathrm{e}}$ & $\mathbf{H}_{\mathbf{o}}$ \\
\hline CH01f02* & 0,88 & 0,94 & 0,79 & & 0,79 & & & & & & \\
\hline CH01h01* & 0,84 & 0,98 & 0,8 & 0,86 & 0,80 & & & & & & \\
\hline $\mathrm{CH} 02 \mathrm{c} 02 \mathrm{a}$ & 0,91 & 0,72 & 0,88 & 0,91 & & & & & & & \\
\hline $\mathrm{CH} 02 \mathrm{c} 09 *$ & 0,86 & 0,76 & 0,77 & & 0,77 & 0,85 & 0,85 & 0,84 & 0,82 & & \\
\hline $\mathrm{CH} 05 \mathrm{e} 03$ & 0,82 & 0,63 & 0,87 & 0,88 & & & & & & 0,86 & 0,45 \\
\hline $\mathrm{CH} 04 \mathrm{e} 03$ & 0,77 & 0,85 & 0,88 & & & & & & & & \\
\hline $\mathrm{CH} 05 \mathrm{~d} 11$ & 0,87 & 0,78 & 0,69 & & & & & & & & \\
\hline $\mathrm{CH} 03 \mathrm{~g} 07$ & 0,83 & 0,91 & 0,77 & & & & & & & & \\
\hline $\mathrm{CH} 02 \mathrm{c} 11 *$ & 0,89 & 0,91 & 0,78 & & 0,78 & 0,86 & 0,90 & 0,88 & 0,82 & & \\
\hline $\mathrm{CH} 02 \mathrm{~d} 08 *$ & 0,83 & 0,87 & 0,82 & 0,86 & 0,82 & 0,70 & 0,74 & 0,87 & 0,89 & & \\
\hline $\mathrm{CH} 03 \mathrm{a} 02$ & 0,86 & 0,80 & 0,87 & & & & & & & & \\
\hline $\mathrm{CH} 05 \mathrm{c} 04$ & 0,78 & 0,81 & 0,8 & & & & & & & & \\
\hline
\end{tabular}

Vizsgálatainkban a CH02c02a marker eredményezte a legnagyobb allélszámot (19), amely marker más kutatóknál (Urbanovich és Kazlovskaya 2009, Gasi et al. 2010, van Treuren et al. 2010) is kiemelkedő számú allélt adott (0. táblázat). A legkevesebb allélt a CH02c09 marker adta, ami szintén egybevág más kutatók eredményeivel (Liebhard et al. 2002, Guarino et al. 2006). Guarino et al. (2006) és Garkava-Gustavsson et al. (2008) vizsgálataiban a CH02c11 marker kétlókuszosnak bizonyult, amiből az egyik lókusz monomorf, 197 bp hosszúságú fragmentumot eredményez. Liebhard et al. (2002), Wichmann et al. (2010) és az általunk végzett mérések ezt nem támasztják alá, a legkisebb detektált fragmentum 206 bp hosszúságú volt. Farrokhi et al. (2011) a CH05e03 és CH05d11 lókuszok 
esetében minden genotípusnál 3 allélt detektált, ami multilókuszosságra utal, de ezt a saját és más kutatók (Galli et al. 2005, Gasi et al. 2010) eredményei szintén nem támasztják alá.

Az allélgyakoriság alapján 49 darab (31\%) ritka (allélgyakoriság 0,05-0,01), és 37 darab (23\%) egyedi allélt találtunk az összesen 160 allél között. Az egyedi allélok száma 1 és 8 között változik lókuszonként. Ezek az értékek hasonlók a szakirodalomban megtalálhatókhoz. Gasi et al. (2010) bosznia-hercegovinai helyi fajták vizsgálatakor 41 (39\%), míg Sikorskaite et al. (2012) litván fajtákban 38 (31\%) egyedi allélt azonosított. Potts et al. (2012) vizsgálataiban az összes allél 39 \%-a ritka allél, míg Garkava-Gustavsson et al. (2008) 53 \%-ban, Hokanson et al. (1998) $59 \%$-ban ritka allélokat detektált. Urbanovich és Kazlovskaya (2009) fehérorosz vad fajokban szintén sok ritka allélt talált. Mivel az egyedi allélok arányát leginkább az alkalmazott markerek és a vizsgált fajták száma, továbbá milyensége (SSR polimorfizmus foka, a vizsgált fajták régi, helyi fajták vagy új, modern fajták) befolyásolja, meglepő, hogy van Treuren et al. (2010) közel 500 fajta vizsgálatakor 16 SSR lókuszon összesen csak 37 (12,5\%) egyedi allélt talált, továbbá Pereira-Lorenzo et al. (2007) 114 galliciai fajtán végzett tanulmányában az összes allél $8 \%$-a bizonyult csak ritkának.

A markeranalízis során tapasztalt ritka és egyedi allélok nagy száma, és a fajták dendrogramon látható nagy távolsága (18. ábra) alátámasztják, hogy a régi fajták óriási értékkel bírnak a genetikai diverzitás szempontjából. Számos kutató felhívja a figyelmet, hogy a fajtahasználat beszükülése a termesztésben ökológiai katasztrófákhoz vezethet. Ennek megakadályozására a régi fajtákat, mint génforrásokat, fel kellene használni (Kellerhals et al. 2012, Tóth et al. 2013).

\subsubsection{A vizsgálatokban használt primerek értékelése}

A kutatásban használt primerek nagyszámú (10-19) allélt és nagy heterozigótasági értéket eredményeztek, ezért alkalmasnak találjuk azokat a fajtagyüjtemények genetikai variabilitásának felmérésére. Az ECPGR által kijelölt markerek (CH01f02, CH01h01, CH02c09, CH02c11, CH02d08) nagy polimorfizmust mutattak. Ezeknél a lókuszonkénti allélok száma 10 és 15 között volt. A várt heterozigótaság nagy volt, 0,83-0,89, és a megfigyelt heterozigótaság egy kivételével ( $\mathrm{CH02c09)}$ minden esetben nagyobb volt a várt értéknél. A Liebhard et al. (2002) által közölt listáról a nagy ploimorfizmus alapján kiválasztott többi primer, ami nincs az ECPGR által kijelölt markerkörben, ugyanolyan nagy allélszámot (11-19) eredményezett, sőt a CH02c02a primer még nagyobb allélszámot (19) is adott. Ezeknél a várt heterozigótaság 0,77-0,91 között volt, tehát nem maradt el jelentősen az ECPGR által kijelölt markerek értékeitől. 
A fragmentumhosszok GenoGrapher szoftverrel történő kiértékelése során azt tapasztaltuk, hogy két primer (CH02d08 és CH05c04) kivételével az összes primer könnyen kiértékelhető csíkokat (band), ill. csúcsokat (peak) adott. E két primer esetében gyakran két csúcsot, köztük pedig két bázispár különbséget tapasztaltunk, és nehéz volt eldönteni, melyik csík, ill. csúcs rendelkezik nagyobb intenzitással. Fontos megemlíteni, hogy a CH02d08 primer szerepel az ECPGR által kijelölt markerkörben. Az is megállapítható, hogy az újabb típusú szekvenálók újabb kiértékelő szoftvereket igényelnek. A PhD kutatásban szereplő markeranalízist még a GenoGrapher szoftverrel értékeltük, de a későbbi vizsgálatokhoz már a Peak Scanner-t használtuk, amivel könnyebben kiértékelhető volt a két problémás primer.

\subsubsection{A fajták allélösszetétele, genetikai ujjlenyomata}

A markeranalízisben szereplő szülőként vizsgálatba vont 'Jonathan', illetve az öt nemzetközi kontroll fajta allélméreteit összevetettük néhány szakirodalomban fellelhető adattal (32. táblázat). A különböző kutatómühelyek eredményeinek összevetését akkor tudjuk sikeresen elvégezni, ha valamennyi rendelkezik egy vagy több azonos fajtával, azaz külső kontrollal, amelyhez viszonyítani tudjuk az adatokat. A legtöbb esetben a saját adatainkkal egyezők, vagy 1-6 bp eltérést mutatnak a különböző kutatómühelyek adatai. Az 1-2 bp a különbség adódhat az eltérő molekulatömegü festékek használatából fakadó mérési hibából. Gyakran azonos kutatómühelyek különböző időben végzett vizsgálatai is pár bp-nyi különbségeket eredményezhetnek, ami felhívja a figyelmet a belső standard használatára, amit minden alkalommal újra bemérünk, és ehhez kalibráljuk a mérést. További okként sorolható fel, hogy a különböző kutatók eltérő kerekítést alkalmaznak az adott lókuszon. A páros ismétlődő egységekből álló lókuszoknál páros számra, míg a páratlan nukleotidszámú ismétlődéseket tartalmazó lókuszoknál páratlanra kellene kerekíteni. Azonban van, aki mindig páros számra, van, aki mindig páratlan számra kerekítve közli az adatokat, míg az újabb publikációk kerekítés nélkül ismertetik az allélméreteket, annak ellenére, hogy így adott lókuszon belül páros és páratlan értékek is lesznek.

A legnagyobb eltéréseket Sikorskaite et al. (2012) által közölt allélhosszok esetén találtuk, így ezeknek az adatoknak a használata kevésbé megbízható. Galli et al. (2005) a 'Pinova' esetében két lókuszon is 3 allélt detektált, míg hozzánk hasonlóan más kutatók is csak 2 allélt kaptak. 
32. Táblázat. A nemzetközi kontroll fajták allélméreteinek összevetése a szakirodalmi adatokkal (*=ECPGR által kijelölt primer)

\begin{tabular}{|c|c|c|c|c|c|c|c|c|c|c|c|c|c|c|c|c|c|c|c|c|c|c|c|c|c|}
\hline \multirow[b]{2}{*}{ Florina } & \multirow[b]{2}{*}{$\begin{array}{l}\text { saját adat } \\
\text { Galli } 2005 \\
\text { Gianfr. } 1998 \\
\text { Liebhard } 2002\end{array}$} & \multicolumn{2}{|c|}{ CH01f02* } & \multicolumn{2}{|c|}{ CH01h01* } & \multicolumn{2}{|c|}{ CH02c02a } & \multicolumn{2}{|c|}{ CH02c09* } & \multicolumn{2}{|c|}{ CH05e03 } & \multicolumn{2}{|c|}{ CH04e03 } & \multicolumn{2}{|c|}{ CH05d11 } & \multicolumn{2}{|c|}{ CH03g07 } & \multicolumn{2}{|c|}{ CH02c11* } & \multicolumn{2}{|c|}{ CH02d08* } & \multicolumn{2}{|c|}{ CH03a02 } & \multicolumn{2}{|c|}{ CH05c04 } \\
\hline & & $\begin{array}{c}184 \\
-2 \\
0\end{array}$ & $\begin{array}{l}208 \\
-2 \\
-2\end{array}$ & $\begin{array}{l}116 \\
+3 \\
+4\end{array}$ & $\begin{array}{l}130 \\
+3 \\
+4\end{array}$ & 145 & 175 & 243 & 247 & $\begin{array}{c}162 \\
+1 \\
0\end{array}$ & $\begin{array}{l}190 \\
+1 \\
-2\end{array}$ & $\begin{array}{c}197 \\
-1 \\
-1\end{array}$ & $\begin{array}{c}199 \\
-1 \\
-1\end{array}$ & $\begin{array}{c}173 \\
0 \\
0\end{array}$ & $\begin{array}{c}197 \\
0\end{array}$ & $\begin{array}{l}120 \\
+3 \\
+3\end{array}$ & $\begin{array}{l}124 \\
+3 \\
+3\end{array}$ & 228 & 232 & 211 & 229 & 119 & 145 & 185 & 207 \\
\hline Gala & $\begin{array}{l}\text { saját adat } \\
\text { Galli } 2005 \\
\text { Sikorskaite } 2012\end{array}$ & 170 & 206 & 118 & 130 & 141 & 179 & $\begin{array}{r}231 \\
+4 \\
\end{array}$ & $\begin{array}{r}241 \\
+5 \\
\end{array}$ & $\begin{array}{c}\mathbf{1 7 2} \\
+1\end{array}$ & $\begin{array}{c}\mathbf{1 8 4} \\
+1\end{array}$ & $\begin{array}{c}197 \\
-1\end{array}$ & $\begin{array}{c}199 \\
-1\end{array}$ & $\begin{array}{c}\mathbf{1 7 3} \\
0\end{array}$ & $\begin{array}{c}173 \\
0\end{array}$ & $\begin{array}{c}116 \\
+3\end{array}$ & $\begin{array}{c}126 \\
+3\end{array}$ & $\begin{array}{r}216 \\
+6 \\
\end{array}$ & $\begin{array}{r}232 \\
+7 \\
\end{array}$ & $\begin{array}{l}225 \\
+2 \\
\end{array}$ & $\begin{array}{r}255 \\
+3 \\
\end{array}$ & 145 & 181 & 199 & 257 \\
\hline Jonathan & $\begin{array}{l}\text { saját adat } \\
\text { Galli } 2005 \\
\text { Gianfr. } 1998 \\
\end{array}$ & $\begin{array}{l}208 \\
-2 \\
\end{array}$ & $\begin{array}{c}208 \\
-2 \\
\end{array}$ & $\begin{array}{r}114 \\
+3 \\
\end{array}$ & $\begin{array}{r}130 \\
+3 \\
\end{array}$ & 175 & 177 & 247 & 255 & $\begin{array}{c}162 \\
+1\end{array}$ & $\begin{array}{c}\mathbf{1 8 4} \\
+1\end{array}$ & $\begin{array}{c}187 \\
-1\end{array}$ & $\begin{array}{c}197 \\
-1\end{array}$ & $\begin{array}{c}173 \\
0\end{array}$ & $\begin{array}{c}175 \\
0\end{array}$ & $\begin{array}{c}116 \\
+3\end{array}$ & $\begin{array}{l}120 \\
+3\end{array}$ & 228 & 234 & 229 & 255 & 119 & 133 & 185 & 185 \\
\hline McIntosh & $\begin{array}{l}\text { saját adat } \\
\text { Galli } 2005 \\
\text { Guarino } 2006 \\
\text { Sikorskaite } 2012\end{array}$ & 174 & 206 & 114 & 116 & 179 & 183 & $\begin{array}{r}231 \\
+3 \\
+4 \\
\end{array}$ & $\begin{array}{l}255 \\
+4 \\
+5 \\
\end{array}$ & $\begin{array}{c}162 \\
+1\end{array}$ & $\begin{array}{c}162 \\
+1\end{array}$ & $\begin{array}{c}185 \\
-1\end{array}$ & $\begin{array}{c}199 \\
-1\end{array}$ & $\begin{array}{c}173 \\
0\end{array}$ & $\begin{array}{c}175 \\
0\end{array}$ & $\begin{array}{c}126 \\
+3\end{array}$ & $\begin{array}{c}166 \\
-1\end{array}$ & $\begin{array}{r}226 \\
+4 \\
+6 \\
\end{array}$ & $\begin{array}{r}226 \\
+6 \\
+8 \\
\end{array}$ & $\begin{array}{l}211 \\
+3 \\
+2 \\
\end{array}$ & $\begin{array}{l}229 \\
+2 \\
+3 \\
\end{array}$ & 119 & 157 & 207 & 207 \\
\hline Pinova & $\begin{array}{l}\text { saját adat } \\
\text { Galli } 2005 \\
\text { Gianfr. } 1998 \\
\text { Gasi } 2010\end{array}$ & $\begin{array}{c}170 \\
-2\end{array}$ & $\begin{array}{l}206 \\
-2\end{array}$ & $\begin{array}{r}118 \\
+3 \\
+1\end{array}$ & $\begin{array}{l}130 \\
+3 \\
+1\end{array}$ & +3 & 185 & 241 & 255 & $\begin{array}{c}172 \\
+7 \\
0\end{array}$ & $\begin{array}{cc}\mathbf{1 7 8} & \\
+7 & 163 \\
& \\
0 & \end{array}$ & $\begin{array}{c}\mathbf{1 8 7} \\
+1\end{array}$ & $\begin{array}{c}199 \\
+3\end{array}$ & $\begin{array}{c}171 \\
-2\end{array}$ & $\begin{array}{c}173 \\
0\end{array}$ & $\begin{array}{c}\mathbf{1 2 6} \\
+1\end{array}$ & $\begin{array}{ll}\mathbf{1 8 0} & \\
129 & 119\end{array}$ & 226 & 232 & $\begin{array}{r}217 \\
+1 \\
+\end{array}$ & 0 & 133 & 157 & 185 & 257 \\
\hline Prima & $\begin{array}{l}\text { saját adat } \\
\text { Garkav-G. } 2008 \\
\text { Galli } 2005 \\
\text { Liebhard } 2002 \\
\text { Sikorskaite } 2012\end{array}$ & 180 & 208 & 114 & 118 & 179 & 179 & $\begin{array}{c}+2 \\
+17 \\
\end{array}$ & $\begin{array}{c}+2 \\
+17 \\
\end{array}$ & $\begin{array}{l}178 \\
+1 \\
-2\end{array}$ & $\begin{array}{c}184 \\
+1 \\
-2\end{array}$ & $\begin{array}{l}185 \\
-1 \\
-1\end{array}$ & $\begin{array}{l}205 \\
-1 \\
-1\end{array}$ & $\begin{array}{c}169 \\
\\
0 \\
+2\end{array}$ & $\begin{array}{c}173 \\
0 \\
+2\end{array}$ & $\begin{array}{l}126 \\
+3 \\
+3\end{array}$ & $\begin{array}{c}166 \\
-1\end{array}$ & $\begin{array}{c}228 \\
0 \\
+3 \\
0 \\
\end{array}$ & $\begin{array}{c}232 \\
0\end{array}$ & $\begin{array}{c}253 \\
+1 \\
\\
+1 \\
-28 \\
\end{array}$ & $\begin{array}{c}255 \\
-1\end{array}$ & 133 & 157 & 185 & 209 \\
\hline
\end{tabular}


A PhD kutatásaimban vizsgált fajták, ill. genotípusok $29 \%$-a bizonyult az allélösszetétele alapján triploidnak, ami hasonló más fajtagyüjteményekben végzett vizsgálatok eredményéhez (Bassil et al. 2009: $26 \%$, Pereira-Lorenzo et al. 2007: 28 \%, Gasi et al. 2010: $21 \%$ ). Van Treuren et al. (2010) a vizsgált fajták $38 \%$-át triploidnak, $2 \%$-át tetraploidnak találták, de eredményeiket nem támasztották alá flow citométeres méréssel. Rouston et al. (2009) vizsgálataiban a vizsgált fajták csupán 8,6\%-ánál mutatkozott triploidra utaló eredmény, és megállapítják, hogy a késői érés és a nagy gyümölcsméret gyakran jellemző a triploidnak bizonyult fajtákra.

A ploidszint megállapításának leggyakoribb módja a flow citométeres mérés. Bodor (2009) a keresztezési vizsgálatokat egészítette ki flow citométeres méréssel. Halász et al. (2011) régi almafajták $S$-genotípusának vizsgálatakor a jelen munkában is szereplő 21 fajta ploidszintjét határozta meg flow citométerrel.

A fajták egy részénél (diploid fajták, valamint a triploidok közül a 'Kanadai renet' és 'Nemes sóvári') SSR adatok alapján feltételezett ploiditási eredményünk megegyezik Halász et al. (2011) flow citométeres mérése alapján meghatározott ploidszinttel (33. táblázat). Ugyanakor a 'Fekete tányéralma', 'Nemes szercsika', 'Orbai alma', 'Szabadkai szercsika' a saját SSR adatok alapján triploid, viszont Halász et al. (2011) flow citométeres és $S$ genotípus meghatározása alapján diploidnak bizonyultak.

33. Táblázat. Saját SSR vizsgálatainkban tapasztalt ploidszint összevetése Halász et al. (2011) S-allél és flow citométer eredményeivel

\begin{tabular}{|c|c|c|c|}
\hline Fajta & $\begin{array}{c}\text { Triploid lókuszok száma } \\
\text { (összesen } 12 \text { vizsgált lókusz) }\end{array}$ & $\begin{array}{c}\text { SSR alapján } \\
\text { feltételezett ploidszint }\end{array}$ & $\begin{array}{l}\text { Flow citométerrel } \\
\text { meghatározott ploidszint } \\
\text { (Halász et al. 2011) }\end{array}$ \\
\hline Batul & & $2 n$ & $2 n$ \\
\hline Beregi sóvári 1 & & $2 n$ & $2 n$ \\
\hline Börkormos renet & & $2 n$ & $2 n$ \\
\hline Fekete tányéralma & 4 & $3 n$ & $2 n$ \\
\hline Gyógyi piros & & $2 n$ & $2 n$ \\
\hline Harang alma & & $2 n$ & $2 n$ \\
\hline Kanadai renet & 8 & $3 n$ & $3 n$ \\
\hline Marosszéki piros & & $2 n$ & $2 n$ \\
\hline Nemes sóvári & 8 & $3 n$ & $3 n$ \\
\hline Nemes szercsika & 2 & $3 n$ & $2 n$ \\
\hline Orbai alma & 8 & $3 n$ & $2 n$ \\
\hline Sikulai & & $2 n$ & $2 n$ \\
\hline Simonffy piros & & $2 n$ & $2 n$ \\
\hline Sóvári nobil & & $2 n$ & $2 n$ \\
\hline Szabadkai szercsika & 6 & $3 n$ & $2 n$ \\
\hline Szászpap alma & & $2 n$ & $2 n$ \\
\hline Tordai alma & 3 & $3 n$ & $3 n$ \\
\hline Tordai piros kálvil & & $2 n$ & $2 n$ \\
\hline Vajki alma & 4 & $3 n$ & $4 n$ \\
\hline Vilmos renet & & $2 n$ & $2 n$ \\
\hline Zöld sóvári & & $2 n$ & $2 n$ \\
\hline
\end{tabular}


A 'Nemes szercsika' esetében két lókuszon tapasztaltunk 3 allélt, ami nem feltétlen jelenti azt, hogy valóban triploid fajtáról van szó. A 'Fekete tányéralma' esetében négy triploid lókuszt találtunk, viszont Halász et al. (2011) flow citométeres eredményei ezt nem támasztják alá. Wichmann et al. (2007, 2010) a 'Fekete tányéralma' fajtát SSR markeranalízis alapján szintén diploidnak találta, így az általunk mért három allél jelenléte nem indokolt, vélhetően mérési hibáról van szó.

A ‘Szabadkai szercsika' 6 lókuszában detektáltunk 3 allélt, ami alapján triploidnak tekinthető lenne a fajta, de ez ellentmond Halász et al. (2011) közlésének. Továbbá Tóth et al. (2013) keresztezéssel, a 'Szabadkai szercsika' apai szülőként való használatával, életképes magoncok felnevelésével és utódvizsgálattal is bizonyította, hogy a fajta pollenje nem steril. Tóth (2013, szóbeli közlés) kétféle keresztezésből származó hibridcsaládban is jelentős gyümölcskötődést tapasztalt. A 'Hesztia' × 'Szabadkai szercsika' keresztezésből 115 megporzásból 26 gyümölcs kötődött (23\%), míg a 'Jonathan M41' × 'Szabadkai szercsika' keresztezésből 97 megporzott virágból 35 db gyümölcs kötődött (36\%). Mindkét esetben nagyon nagy volt a teltmagvak aránya, és az elvetett magvak 95\%-a életképes csíranövényeket eredményezett. A két megelőző tanulmány miatt arra a következtetésre jutottunk, hogy a 'Szabadkai szercsika' minden bizonnyal diploid.

Az 'Orbai alma' esetében 8 triploid lókuszt találtunk, amely elég jelentős arány ahhoz, hogy Halász et al. (2011) eredményeire hagyatkozva elvessük a fajta triploid voltát. E fajta is bizonyítja, hogy a ploiditás többoldalú vizsgálatára van szükség, ezért javasolt az $S$ genotípus, az SSR és a flow citométeres vizsgálatok megismétlése, és megporzási kísérletekkel kiegészítése.

Az SSR adatok alapján triploidnak, flow citométer alapján tetraploidnak mért 'Vajki alma' tetraploid voltát nem cáfolhatjuk, hiszen előfordulhat, hogy homozigóta allélok is előfordulnak a detektált allélok között. Halász et al. (2011) a tetraploid 'Vajki alma' esetében három $S$-allélt talált, és megállapítja, hogy a tetraploidoknál soha nincs négy allél, amelyre a heteroallélikus pollen lehet a magyarázat. Wichmann et al. (2007, 2010) által is mért fajták esetében az esetek felében a miénkkel azonos allélszámot tapasztaltak (35. táblázat). Néhány, általunk diploidnak mért fajtánál ('Fertődi téli’, 'Széchenyi renet') 3 allélt detektáltak, de csak egyetlen lókuszon, ezért nem jelenthető ki, hogy eltérő ploiditást tapasztaltak. Wichmann et al. $(2007,2010)$ eredményével ellentétben a 'Dániel féle renet' és a 'Fekete tányéralma' viszont a mi vizsgálatainkban több lókuszon triploidnak bizonyult. 
34. Táblázat. A vélhetően triploid fajtáknál a triploid lókuszok neve és száma ( $\mathrm{X}=3$ allélt detektáltunk; *=ECPGR által kijelölt primer)

\begin{tabular}{|c|c|c|c|c|c|c|c|c|c|c|c|c|c|}
\hline & LG & & LG3 & LG5 & LG10 & LG11 & LG & & LG13 & LG14 & LG15 & LG17 & \\
\hline Fajta & CH02c02a & CH05e03 & CH03g07 & CH04e03 & CH02c11* & CH02d08* & CH01f02* & CH05d11 & CH05c04 & CH03a02 & CH02c09* & CH01h01* & $\begin{array}{c}\text { Triploid } \\
\text { lókuszok száma } \\
(\mathbf{n} / \mathbf{1 2})\end{array}$ \\
\hline Beregi sóvári 2 & & & & & & $X$ & & & & $\mathrm{X}$ & & & 2 \\
\hline Cigány alma & & & $\mathrm{X}$ & & & $\mathrm{X}$ & $X$ & & & & & & 3 \\
\hline Dániel féle renet & & & $\mathrm{X}$ & & & $\mathrm{X}$ & $\mathrm{X}$ & & & & & & 3 \\
\hline Entz Rozmaring & $\mathrm{X}$ & $\mathrm{X}$ & $\mathrm{X}$ & $\mathrm{X}$ & & $\mathrm{X}$ & & $X$ & & & $X$ & & 7 \\
\hline Fekete tányéralma & & & $\mathrm{X}$ & & $\mathrm{X}$ & $\mathrm{X}$ & & & $X$ & & & & 4 \\
\hline Honti alma & & & & & $\mathrm{X}$ & & & $X$ & $\mathrm{X}$ & & $\mathrm{X}$ & $X$ & 5 \\
\hline Húsvéti rozmaring & $\mathrm{X}$ & $X$ & $X$ & $X$ & & $\mathrm{X}$ & & $X$ & & & $X$ & & 7 \\
\hline Kanadai renet & $X$ & $X$ & $\mathrm{X}$ & $X$ & $\mathrm{X}$ & $\mathrm{X}$ & & & & & $X$ & $X$ & 8 \\
\hline Királyi renet & & & $\mathrm{X}$ & & $\mathrm{X}$ & & & & & & $\mathrm{X}$ & & 3 \\
\hline Lóci édes almája & $\mathrm{X}$ & & & & & & & $X$ & & $\mathrm{X}$ & & $\mathrm{X}$ & 4 \\
\hline Nemes sóvári & $\mathrm{X}$ & $X$ & & & $\mathrm{X}$ & $\mathrm{X}$ & $X$ & $\mathrm{X}$ & $\mathrm{X}$ & & $X$ & & 8 \\
\hline Nemes szercsika & & & $X$ & & $\mathrm{X}$ & & & & & & & & 2 \\
\hline Nyári fontos & & & & & $\mathrm{X}$ & & & $X$ & & & $\mathrm{X}$ & & 3 \\
\hline Orbai alma & & & $X$ & $\mathrm{X}$ & & $\mathrm{X}$ & $X$ & & $X$ & $X$ & $X$ & $X$ & 8 \\
\hline Sándor cár & $\mathrm{X}$ & & $\mathrm{X}$ & & $\mathrm{X}$ & $\mathrm{X}$ & $\mathrm{X}$ & & & & & & 5 \\
\hline Szabadkai szercsika & $\mathrm{X}$ & $\mathrm{X}$ & $\mathrm{X}$ & $X$ & & & & $X$ & & & $\mathrm{X}$ & & 6 \\
\hline Tordai alma & & & & & $X$ & & & $\mathrm{X}$ & & & $\mathrm{X}$ & & 3 \\
\hline $\begin{array}{l}\text { Adott lókuszon } \\
\text { triploid fajták száma } \\
(\mathrm{n} / 20)\end{array}$ & 7 & 5 & 11 & 5 & 9 & 10 & 5 & 8 & 4 & 3 & 10 & 4 & \\
\hline
\end{tabular}


Az allélösszetétele alapján triploidnak mutatkozó fajták flow citométeres poliditás vizsgálatát megkezdtük, de még nincsenek végleges eredmények, így a legtöbb esetben csak a mikroszatellit vizsgálatok eredményei alapján feltételezzük a ploidszintet. A kontroll fajtákon kívül biztosan csak a 'Cserepánya' és a 'Csíkos óriás halasi' fajták ploidszintjét tudtuk flow citométerrel megbízhatóan meghatározni. Ennél a két fajtánál 4, illetve 9 lókuszon három allélt detektáltunk, de a flow citométeres mérés szerint tetraploidnak bizonyultak (Nagyistván 2012), amely eredmény egyezik a 'Vajki alma' esetében tapasztaltakkal. Újabb megerősítés a heteroallélikus pollennel történő öntermékenyülésre.

Megállapítható tehát, hogy a mi eredményeinkben a 78 vizsgált genotípusból 55 diploid, és valószínüleg 17 fajta triploid (ㄴ. táblázat), és három fajta ('Vajki alma', 'Cserepánya' és 'Csíkos óriás halasi') pedig tetraploid az allélösszetétele alapján. Ezt azonban nem tekinthetjük kész ténynek, mert a lókuszonkénti kettőnél több allél jelenléte nem feltétlenül poliploiditást jelent, hanem lehet mérési hiba, vagy jelezheti kiméra jelenlétét, vagy multilókuszosságot is. Mivel a fajták többségénél nem kaptunk kettőnél több allélt egyik lókuszon sem, így a multilókuszosságot kizárhatjuk, annak ellenére, hogy néhány kutató két lókuszt tapasztalt egyes markereknél (ld. előző fejezet). A vizsgálatban szereplő ECPGR által kijelölt markerkörben megtalálható primerek biztos nem multilókuszosak, és a többi lókusznál sem bizonyított a multilókuszosság.

Evans et al. (2011) a nagyszámú (300) vizsgált fajta között arányaiban jóval kevesebb (8 fajta) triploidot találtak, mint más kutatók, ezért javasolják, vegyük figyelembe a kromoszóma duplikációból vagy homológ kromoszómákról származó esetleges

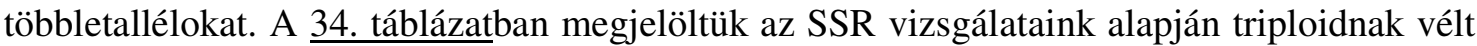
fajtáknál a három allélt mutató lókuszokat. A legtöbb triploid adattal rendelkező lókusz a CH02c11 és a CH03g07. A kromoszómaszám változást eredményező mutációt (kiméra) a kapcsoltsági csoportok alapján kizárhatjuk, mert a LG12-n két primert is használtunk, de ezek nem minden fajtánál adtak három allélt. Az ECPGR által kijelölt markerek és a többi marker által eredményezett triploid lókuszok számát összevetve azt tapasztaljuk, hogy a nem kiemelt marker gyakran adott három allélt a bizonyíthatóan diploid fajtáknál, mint az ECPGR által kijelölt markerek. Ezért az utóbbiakat megbízhatóbbnak tartjuk a ploiditásra vonatkozó megállapításokhoz.

A legbiztosabb választ a kromoszómaszám meghatározás adná, de ezt számos tényező nehezíti a fás szárú növények esetében. Leggyakrabban gyökércsúcsból végzik a vizsgálatot, de az almát oltványról termesztjük, a nemes fajta gyökereztetése nagyon nehéz, így ez a módszer gyakorlatilag nem kivitelezhető. Az alma kromoszómáinak kis mérete $(1,5-3,5 \mu \mathrm{m})$ és a nagy száma (2n=34) tovább nehezíti a számlálást (Bouvier et al. 2000). 
Wichmann et al. (2007, 2010) az újfehértói génbank magyar tájfajtáit vizsgálta,

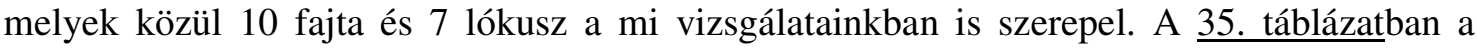
nemzetközi fajtákhoz hasonló összevetést készítettünk. Mivel ezekben a publikációkban nem szerepel egyik kontroll fajta sem, amit a HiDRAS a honlapjukon (www.hidras.unimi.it) javasol és/vagy mi alkalmaztunk, ezért nehéz az adatok összevetése. Azt megállapíthatjuk,

hogy a 'Nyári fontos' és a 'Téli arany parmen' fajták valószínüleg azonosak a két kutatói mühely adatai alapján, bár 1-3 bp eltérések tapasztalhatók, ami az eltérö molekulatömegü festék használatából adódhat. Saját vizsgálatainkban a 'Fekete tányéralma’-nál 4 lókuszon is 3 allélt detektáltunk, de ha ezeket a lókuszokat figyelmen kívül hagyjuk, akkor az eredményeink megegyeznek a Wichmann et al. (2007, 2010) által közölttel. Ök a CH03g07 lókuszon a 'Fertődi téli' és a 'Széchenyi renet' fajtáknál 3 allélt detektáltak, ami ellentmond a saját adatainknak. A 'Fertődi téli', 'Sikulai' és 'Simonffy piros' fajtáknál a lókuszok nagy része azonos (max. 1-4 bp eltérés) allélokat mutat a két tanulmányban, de néhány lókuszon olyan nagy a különbség (14-46 bp), hogy nem jelenthetjük ki a mérési hibát. Ennek ellenére valószínűleg azonos fajtacsoportba tartoznak a fajták, valószínűleg azonos fenotípusos jellemzőkkel bírnak, de inszerció vagy deléció miatt a genotípusukban van némi eltérés. További következtetések csak akkor lennének levonhatók, ha a két vizsgálat fajtáit azonos laboratóriumi körülmények között újra megvizsgálnánk.

Ami viszont egyértelmủen látszik az adatok összevetéséből, hogy a 'Dániel féle renet', 'Simonffy piros', 'Széchenyi renet' és a 'Tordai piros kálvil' Soroksárról és Újfehértóról származó mintája nem azonos, homonimák lehetnek. A soroksári 'Tordai piros kálvil' Bereczki leírásától eltérő morfológiai jellemzőire már Tóth (2005b) és Tóth et al. (2013) is rámutattak, amikor a kiemelkedő tủzelhalással szembeni ellenálló-képességét értékelték.

\subsection{Fajtacsoportok, szinonimák, fajtaazonosság a morfológiai és a molekuláris vizsgálatok alapján}

A fajtacsoportok értékelését, a szinonimák azonosítását a morfológiai és a molekuláris vizsgálatok eredményeinek együttes figyelembevételével végeztük el, mert reális képet és a fajták rokonsági viszonyainak kérdésére egyértelmü válaszokat nagyobb biztonsággal kaphatunk a két módszer alapján. 
35. Táblázat. Régi magyar almafajták allélméreteinek összevetése a szakirodalmi adatokkal (*=ECPGR által kijelölt primer)

\begin{tabular}{|c|c|c|c|c|c|c|c|c|}
\hline & & CH02c09* & CH05e03 & CH04e03 & CH05d11 & CH03g07 & CH02c11* & CH02d08* \\
\hline Dániel féle renet & $\begin{array}{l}\text { saját adat } \\
\text { Wichmann } 2007,2010\end{array}$ & $\begin{array}{lll}231 & 239 & \\
+12 & +14 & 255 \\
\end{array}$ & $\begin{array}{cc}162 & 172 \\
+1 & \\
\end{array}$ & \begin{tabular}{cc|}
197 & 205 \\
-1 & -1 \\
\end{tabular} & $\begin{array}{cc}\mathbf{1 7 5} & \mathbf{1 8 7} \\
0 & -18 \\
\end{array}$ & \begin{tabular}{ccc|}
120 & 126 & 170 \\
-1 & & \\
\end{tabular} & $\begin{array}{|cc|}\mathbf{2 2 0} & \mathbf{2 1 6} \\
-14 & 0 \\
\end{array}$ & $\begin{array}{ccc}\mathbf{2 1 1} & \mathbf{2 1 7} & \mathbf{2 5 5} \\
0 & +6 & \\
\end{array}$ \\
\hline Fekete tányéralma & $\begin{array}{l}\text { saját adat } \\
\text { Wichmann } 2007,2010\end{array}$ & \begin{tabular}{cc|}
253 & $\mathbf{2 5 5}$ \\
0 & -2 \\
\end{tabular} & $\begin{array}{cc}172 & 190 \\
+1 & +1 \\
\end{array}$ & $\begin{array}{cc}197 & 203 \\
-1 & -1 \\
\end{array}$ & $\begin{array}{|ccc|}195 & 195 & \\
0 & & 225 \\
\end{array}$ & $\begin{array}{|ccc|}116 & 126 & 166 \\
+3 & +3 & \\
\end{array}$ & $\begin{array}{|ccc|}206 & 230 & 236 \\
0 & & \\
\end{array}$ & $\begin{array}{|ccc|}\mathbf{2 2 3} & \mathbf{2 2 5} & \mathbf{2 5 5} \\
0 & 0 & \\
\end{array}$ \\
\hline Fertődi téli & $\begin{array}{l}\text { saját adat } \\
\text { Wichmann } 2007,2010\end{array}$ & $\begin{array}{cc}255 & 255 \\
0 & 0 \\
\end{array}$ & $\begin{array}{cc}162 & 168 \\
+1 & 0 \\
\end{array}$ & $\begin{array}{cc}185 & 197 \\
-1 & -1 \\
\end{array}$ & $\begin{array}{|cc|}163 & 173 \\
& 0 \\
\end{array}$ & $\begin{array}{|ccc|}120 & 124 & \\
-1 & -1 & 129 \\
\end{array}$ & $\begin{array}{|cc|}218 & 226 \\
0 & -4 \\
\end{array}$ & $\begin{array}{ll}247 & \mathbf{2 5 5} \\
-32 & -40 \\
\end{array}$ \\
\hline Húsvéti rozmaring & $\begin{array}{l}\text { saját adat } \\
\text { Wichmann 2007, } 2010\end{array}$ & $\begin{array}{ccc}\mathbf{2 4 3} & \mathbf{2 4 7} & \mathbf{2 5 3} \\
-2 & 0 & \end{array}$ & $\begin{array}{|ccc|}162 & 172 & 190 \\
& & +1\end{array}$ & $\begin{array}{ccc}193 & 197 & 203 \\
-1 & -1 & -1 \\
\end{array}$ & $\begin{array}{|ccc|}187 & \mathbf{1 9 5} & \mathbf{2 0 5} \\
0 & 173 & 0 \\
\end{array}$ & $\begin{array}{|ccc|}116 & 124 & 126 \\
+3 & & +3 \\
\end{array}$ & $\begin{array}{cc}222 & 232 \\
0 & \\
\end{array}$ & $\begin{array}{ccc}\mathbf{2 1 1} & \mathbf{2 1 7} & \mathbf{2 4 7} \\
0 & 0 & \\
\end{array}$ \\
\hline Nyári fontos & $\begin{array}{l}\text { saját adat } \\
\text { Wichmann } 2007,2010\end{array}$ & $\begin{array}{ccc}231 & \mathbf{2 4 3} & \mathbf{2 5 5} \\
0 & 0 & \\
\end{array}$ & $\begin{array}{cc}160 & 172 \\
+1 & +1 \\
\end{array}$ & \begin{tabular}{cc|}
197 & 223 \\
-1 & -1 \\
\end{tabular} & $\begin{array}{|ccc|}171 & 181 & 187 \\
0 & 0 & 0 \\
\end{array}$ & $\begin{array}{|cc|}116 & 126 \\
+3 & +3 \\
\end{array}$ & \begin{tabular}{ccc|}
218 & 220 & 234 \\
-2 & +2 & \\
\end{tabular} & $\begin{array}{cc}211 & 225 \\
0 & 0 \\
\end{array}$ \\
\hline Sikulai & $\begin{array}{l}\text { saját adat } \\
\text { Wichmann } 2007,2010\end{array}$ & $\begin{array}{cc}231 & 251 \\
0 & \\
\end{array}$ & $\begin{array}{cc}162 & 192 \\
+1 & +1 \\
\end{array}$ & $\begin{array}{cc}197 & 211 \\
-1 & -1 \\
\end{array}$ & $\begin{array}{|ccc|}177 & 207 & \\
0 & & 175 \\
\end{array}$ & $\begin{array}{cc}126 & 166 \\
+3 & -1 \\
\end{array}$ & $\begin{array}{cc}232 & 236 \\
-16 & -14\end{array}$ & $\begin{array}{cc}217 & \mathbf{2 2 5} \\
0 & 0\end{array}$ \\
\hline Simonffy piros & $\begin{array}{l}\text { saját adat } \\
\text { Wichmann 2007, } 2010\end{array}$ & $\begin{array}{cc}\mathbf{2 3 1} & \mathbf{2 4 7} \\
0 & 0\end{array}$ & $\begin{array}{cc}160 & 172 \\
0 & +1\end{array}$ & $\begin{array}{cc}197 & 201 \\
-1 & -1\end{array}$ & $\begin{array}{|ccc|}171 & 171 & \\
+2 & & 227 \\
\end{array}$ & $\begin{array}{cc}126 & 126 \\
-7 & +3\end{array}$ & $\begin{array}{cc}206 & 218 \\
0 & 0\end{array}$ & $\begin{array}{|ll|}255 & 255 \\
-46 & -46\end{array}$ \\
\hline Széchenyi renet & $\begin{array}{l}\text { saját adat } \\
\text { Wichmann } 2007,2010\end{array}$ & $\begin{array}{|cc|}231 & 253 \\
+16 & -6 \\
\end{array}$ & $\begin{array}{cc}172 & 178 \\
-1 & +1 \\
\end{array}$ & $\begin{array}{cc}197 & 223 \\
-1 & -1 \\
\end{array}$ & $\begin{array}{|cc|}171 & 175 \\
0 & 0 \\
\end{array}$ & $\begin{array}{|ccc|}126 & 152 & \\
+3 & +1 & 165 \\
\end{array}$ & $\begin{array}{|cc|}206 & 230 \\
0 & -8 \\
\end{array}$ & $\begin{array}{cc}213 & 255 \\
-2 & \\
\end{array}$ \\
\hline Téli arany parmen & $\begin{array}{l}\text { saját adat } \\
\text { Wichmann } 2007,2010\end{array}$ & 253253 & $\begin{array}{cc}162 & 162 \\
+1 & +1 \\
\end{array}$ & $\begin{array}{cc}197 & 199 \\
-1 & -3 \\
\end{array}$ & $\begin{array}{cc}169 & 175 \\
0 & 0 \\
\end{array}$ & \begin{tabular}{cc|}
126 & 152 \\
+3 & +1 \\
\end{tabular} & 216230 & 229255 \\
\hline Tordai piros kálvil & $\begin{array}{l}\text { saját adat } \\
\text { Wichmann } 2007,2010\end{array}$ & \begin{tabular}{|cc}
231 & 243 \\
+16 & +4 \\
\end{tabular} & $\begin{array}{ll}162 & 162 \\
+11 & +29 \\
\end{array}$ & $\begin{array}{cc}199 & 199 \\
-3 & +5 \\
\end{array}$ & $\begin{array}{|ccc|}171 & 171 & \\
0 & +4 & 187 \\
\end{array}$ & \begin{tabular}{|c|c|}
120 & 176 \\
-1 & -47 \\
\end{tabular} & $\begin{array}{|cc|}206 & 206 \\
0 & +8 \\
\end{array}$ & $\begin{array}{cc}211 & 211 \\
-2 & +4 \\
\end{array}$ \\
\hline
\end{tabular}


A fajták UPOV TG/14/9 irányelveiben meghatározott 56 tulajdonság szerinti számkulcsos adataiból készített hasonlósági mátrix alapján hierarchikus klaszteranalízist végeztünk. Az ennek alapján készített dendrogramon jól látszik a hat főcsoport. A markeranalízis során elkészítettük a fajták genetikai ujjlenyomatát. Az összefüggések szemléltetésére a fragmentumhosszokból a Jaccard-indexen alapuló genetikai távolság mátrix alapján készítettünk dendrogramot, melyen hét nagy csoportot figyelhetünk meg.

A vizsgált fajták között megtalálhatók a Kárpát-medencében elterjedt, de vélhetően, vagy biztosan nem magyar származású fajták is pl. 'Ontario’ és ‘Tartós Gusztáv'. Sajnos a vizsgálatba vont fajták származására nézve kevés az információ. A Kárpát-medence egész területéről származhatnak, de a legtöbb fajta erdélyi. Néhány fajta Kárpátalja, Délvidék, az Alföld vagy a Dunántúl területéről származik (1. táblázat).

Laurens et al. (2004), Hokanson et al. (2001) és Potts et al. (2012) SSR vizsgálati eredményeihez hasonlóan a fajták földrajzi származása és a kapott klaszterek között nem találtunk összefüggést, mind a külföldi régi és a modern fajták, mind a Kárpát-medencében keletkezett fajták vegyes eloszlást mutatnak. A dendrogram nem tükrözi a Kárpát-medence tájegységeit sem, így a morfológiai és a genetikai hasonlóság nem fedi fel a származást. Más következtetésre jutottak Patzak et al. (2009) és Urbanovich és Kazlovskaya (2009), akik megállapították, hogy a klaszterbe sorolás nagymértékben függ a fajták pedigréjétől és a földrajzi származásától. Song et al. (2006) az ipari és friss étkezési fajtákat sikeresen sorolták be klaszterekbe, az egyes klaszterek szemléltették a származás és a beltartalmi hasonlóságokat. Pereira-Lorenzo et al. (2008) molekuláris vizsgálataikban jelentős eltéréseket mutattak ki a spanyol és a nemzetközi fajták között. Gasi et al. (2010) munkájukban a molekuláris adatok alapján a nemzetközi fajták jól elkülönültek a hagyományos fajtáktól, viszont a morfológiai adatok alapján ez nem jelenthető ki egyértelmüen.

A vizsgált fajták nagy genetikai variabilitására mutat rá mindkét dendrogram, mert a rügymutációval keletkezett fajták, ill. fajtacsoportok kivételével nem találtunk egymáshoz közel elhelyezkedő fajtákat, hanem mind a molekuláris, mind a morfológiai hasonlósági indexek igen nagy távolságot mutattak. A nagyobb klasztereken belül nem találtunk összefüggést a fajták között, Bassil et al.-hoz (2009) hasonlóan a kisebb klaszterekben mégis sikerült fajtacsoportok kialakítása. Laurens et al. (2004) is csak néhány kisebb fajtacsoportot tudtak klaszterbe sorolni, de a molekuláris adatok nem adták a francia fajtáknál elterjedt három fenotípus szerinti fajtacsoportot ('Reinette', 'Calville', 'Court-Pendu'). 


\subsubsection{Fajtacsoportok rokonsági viszonyai}

\section{Batul fajtacsoport}

A dendrogramon egy külön föklasztert alkot a Batul fajtacsoport. A morfológiai és a molekuláris adatokon alapuló dendrogramok (17-18. ábra) egyik kisebb klaszterét a 'Batul' genotípusok adják, a 'Zöld batul' kivételével. Az allélösszetétel alapján a 'Batul' 2. és 3. genotípusa és a 'Mosolygós batul' $100 \%$-ban azonosnak mutatkozott, és a 'Batul' 1 . genotípusa és a 'Fehér batul' csak egyetlen lókuszon mutatott 2 bp különbséget. A morfológiai adatok alapján a 'Batul' 1. és 3. genotípusa adott $100 \%$-os egyezést, és a 'Batul' 2. genotípusa és a 'Mosolygós batul' a tulajdonságok $95 \%$-ában azonos volt az előző két genotípussal. Ezzel tisztázódtak a korábbi pomológiai kételyek a 'Batul' és a 'Mosolygós batul' azonosságáról. Az eredmények alapján nem tudtuk elkülöníteni a két fajtát egymástól. A mosolygós kifejezés a piros színeződésre utal, de a gyüjteményünkben lévő Batul genotípusok és a Mosolygós batul azonosan színeződött, pontosabban színeződés csak a gyümölcsök kis százalékán, és azokon is csak a napos oldalon, kis kiterjedésben fordult elö. Az 56 UPOV tulajdonság közül néhány esetben találtunk eltérést a másik 3 Batul genotípustól. De ha megnézzük, akkor az elméletileg azonos 3 Batul alapfajta sem mutatott 100 \%-os morfológiai egyezést. Ennek oka a vegetatív szaporítás során jelentkező fajta leromlás lehet.

Ez az eredmény várható volt, hiszen számos szakirodalom felhívja a figyelmet a Batul fajtacsoportba tartozó fajták hasonlóságára és elkülönítésük nehézségeire. Miközben az alapfajta pomológiai leírásának megbízhatósága vitathatatlan, a változatok leírása tisztázatlan. Például egyes leírásokban (Girókúti 1863, Kerekes 1937) föcímként a 'Batul' szerepel, a jellemzés végén pedig megemlíti a szerző, hogy ez a leírás a 'Mosolygós batul'-ra vonatkozik. Nem kapunk világos útmutatást arról, hogy miben különbözik a két fajta. Oberdieck és Lucas (1860) külön fajtaként, 'Mosolygi alma' néven említ egy erdélyi almafajtát, amely a leírás alapján valószínűleg a Mosolygós batul. Az ugyanebben a müben ismertetett 'Batul' és leírása viszont nem különbözik a 'Mosolygi alma' néven említett fajtáétól. Nagy-Tóth (1998) szerint több különböző almafajtát neveztek 'Mosolygó alma'nak. Az Ocfalván talált 'Mosolygós batul' almáról azt írja, hogy több tulajdonságában a 'Batul' fajtához hasonlít, annak magonca lehet, s erről többek között Bereczki (1899) és Bordeianu et al. (1964) is hasonlóan vélekednek. Ugyanez a kusza kép rajzolódik ki a 'Batul' többi változatáról is, ezért említi Brózik és Régius 1957-ben, hogy fajtaköre még nincs feldolgozva.

A 'Zöld batul' a morfológiai és a molekuláris vizsgálatokban is egy teljesen másik főklaszterbe került, távol a többi vizsgált 'Batul' genotípustól. A levél, virág és gyümölcs 
jellemzői nemcsak együttesen, hanem külön-külön is egyértelmủen alkalmasak a 'Zöld batul' többi 'Batul' típustól megkülönböztetésére. A markeranalízis során is csak négy lókusz egyegy alléljában mutatott hasonlóságot a 'Batul' többi vizsgált típusához. A két vizsgálati módszer eredményei és az eltérő virágzási idő alapján a 'Zöld batul' nem mutat közvetlen rokonságot a 'Batul' fajtával, hanem bizonyára az alapfajta távoli leszármazottja lehet, s ezért a jövőben ezt a fajtát külön fajtaként kell nyilvántartani.

\section{Renet fajtacsoport}

A fenotípusos tulajdonságok és a genetikai ujjlenyomatuk alapján a fajták jól elkülöníthetők egymástól. A dendrogramokon látható a Renet fajták sokfélesége, mert szinte az összes vizsgált fajta különböző föklaszterbe került, és az egy főklaszterbe kerülő Renetek is nagy távolságban, külön alklaszterben helyezkednek el.

A Renet fajtákat a gyümölcsjellemzők, elsősorban az íz alapján sorolják közös csoportokba a pomológusok. A Renetekre jellemző a tömött, finom és porhanyó hús, a különleges füszeres íz (Rapaics 1937). Az egyik leggazdagabb fajtacsoport. Az általunk vizsgált Renet fajtákat a legegyszerübben Diel (1799) csoportosítási módszere szerint sorolhatjuk be, aki 4 alcsoportba sorolja a Reneteket: egyszínü renetek ('Királyi renet'), piros renetek ('Dániel féle renet', 'Baumann renet', 'Vilmos renet', 'Széchenyi renet'), szürke vagy kormos renetek ('Bőrkormos renet', 'Kanadai renet'), aranyrenetek. Bereczki Máté az 1882-87 között megjelent négy kötetes Gyümölcsészeti vázlatok címü könyvében 64 Renetet, Diel a Kernobstsorten (Almatermésűek) címü gyüjteményes mű 1799-1816 között megjelent, almával foglalkozó 12 füzetében több, mint 200 Renet fajtát ismertetett, így az általunk vizsgált 7 Renet fajta csak csekély betekintést nyújt ebbe a gazdag és népes fajtacsoportba.

A 'Kanadai renet' szelekciók csoportja azonban külön klasztert alkotott mindkét dendrogramon. Halász et al. (2011) az $S$-genotípus alaján különbséget találtak az angol nemzeti fajtagyüjteményben megörzött és a Tóth (2005a) által Kárpátalján begyüjtött, és a soroksári génbankban megőrzött 'Kanadai renet' között. Mindkét fajta triploid volta, és hogy a három $S$-allélból kettő azonos a két genotípusban, arra enged következtetni, hogy szülöutód kapcsolatról lehet szó. Diel (1799) szerint a Renet fajták a hasonló morfológiai tulajdonságaik alapján képeznek fajtacsoportot. A három vizsgált genotípus ránézésre fajtaazonosnak tünt, csak a gyümölcs méretében fedeztünk fel szemmel látható különbséget. Ennek ellenére elvégeztük mindhárom egyed teljes morfológiai és SSR vizsgálatát. Két morfológiai tulajdonságban (kocsány vastagsága és gyümölcshús színe) ugyan eltérő adatot kaptunk a három genotípusnál, de genetikai ujjlenyomatuk $100 \%$-ban azonos volt. A 
gyümölcshús színének eltérő kategóriába sorolása adódhat az eltérő időben végzett vizsgálatból, ill. a vizsgálatot végző személy szubjektivitásából is. Ez felhívja a figyelmet a fenotípusos vizsgálatok környezeti és emberi tényezők általi befolyásolhatóságára. Számos tanulmány (Federico et al. 2008, Santesteban et al. 2009) hasonló következtetésekre jutott a fenotípusos és genotípusos jellemzések összevetésekor.

\section{Sóvári fajtacsoport}

A Sóvári fajták a feltételezett közös származás alapján képeznek fajtacsoportot, mert a legtöbb szakirodalmi forrás a 'Közönséges sóvári' változataként ismerteti ezeket. Az SSR vizsgálatokba 7, míg a morfológiai jellemzésbe 6 Sóvári genotípust vontunk be. A levél, virág és gyümölcs morfológiai jellemzőinek külön-külön használata nem alkalmazható egyértelmüen a fajták megkülönböztetésére, így komplex használatuk javasolt. A fenotípusos adatatok alapján készített dendrogramon a Sóvári fajtacsoport három fajtája ('Nemes sóvári', 'Zöld sóvári', 'Daru sóvári') egy kisebb klasztert alkotott, a 'Sóvári nobil'-t ugyanabban a főklaszterben, míg a 'Beregi sóvári’ genotípusokat teljesen külön főklaszterben találjuk. Allélösszetételük alapján is feltételezhető a rokonságuk, hiszen néhány lókuszon néhány fajtapár között találunk azonos allélokat, de ez inkább csak távoli rokonságra és nem közvetlen leszármazásra enged következtetni. Az SSR-dendrogramon elfoglalt helyzetük alapján a 'Sóvári nobil', a 'Daru sóvári', a 'Téli sóvári’ és a 'Zöld sóvári’ ugyanabban a főklaszterben található, de a fajták közti távolság nagyon nagy. Ettől eltérő két külön főklaszterbe került a 'Nemes sóvári’ és a két 'Beregi sóvári' genotípus.

A szinonimának tartott 'Nemes sóvári' és az Angol Nemzeti Fajtagyüjteményben fenntartott 'Sóvári nobil' a morfológiai és a molekuláris eredmények alapján nem tekinthető azonos fajtának, tehát nem nevezhetjük azokat szinonimának. Ezt az eredmény alátámasztja Halász et al. (2011) S-genotípusra vonatkozó vizsgálata is, amelyben a 'Nemes sóvári' Kárpátaljáról származó egyedét triploidnak, az Angliából származót (ebben a dolgozatban 'Sóvári nobil' néven szerepel) pedig diploidnak találta, amit flow citométeres vizsgálataik is megerősítettek. A két genotípusban az $S$-allél összetétele is eltérő volt.

A két 'Beregi sóvári' genotípus (angliai és kárpátaljai) nem mutat morfológiai hasonlóságot. A legjelentősebb különbség a virágok és gyümölcsök vizsgálatakor volt tapasztalható, amely megkérdőjelezi a két fajta azonosságát. Annak ellenére, hogy hat lókuszon egy-egy közös allélt találtunk, igen nagy genetikai távolságot mutattak a dendrogramon. Ezen komplex vizsgálati eredményeink szerint a 'Beregi sóvári' Angliából visszahozott és Kárpátaljáról begyüjtött típusai nem tekinthetők azonos fajtának, s bebizonyosodott, hogy az utóbbi egyezik meg a Bereczki Máté által leírt fajtával. Ezért a 
'Beregi sóvári' Angol Nemzeti Fajtagyüjteményben (Morgan és Richards 1993) található egyedet ismeretlen genotípusnak kell tekinteni. Halász et al. (2011) az Angliából származó egyed $S$-genotípusát határozták meg.

Mint azt korábban ismertettük, Sóvári gyüjtőnév alatt egy fajtakört kell értenünk, mivel igen sok formája létezik. Wichmann et al. (2010) a 'Nyári sóvári' és a 'Puha sóvári' fajtákat vizsgálta. Ezeknél a fajtáknál nem találtak a mi fajtáinkkal $100 \%$-ban azonos fragmentumméretü allélokat ugyanazon lókuszokban, tehát nem szinonimái a jelen vizsgálatban szereplő fajtáknak. Viszont néhány közös allél felfedezhető, ami a közös származásra utalhat, a különböző kutatómühelyek adatainak összevetésével azonban óvatosan kell bánni.

\subsubsection{Szinonimák azonosítása}

Simonffy piros - Cigány alma - Roter Stettiner - Török Bálint

A 'Cigány alma' elnevezést gyüjtőnévnek tekinthetjük, mert sok, sötétpiros színü gyümölcsökkel rendelkező tájfajtát neveznek így. A gyakran szinonimaként ismert 'Cigány alma' és 'Simonffy piros' vizsgálatba vont genotípusai a fa habitusától kezdve a gyümölcsméretig már ránézésre jelentős különbségeket mutattak. Közös tulajdonságként jegyezhetjük fel többek között a sötét, liláspirosra színeződő gyümölcshéjat. A két fajta az UPOV kategóriák szerinti morfológiai jellemzés alapján is egyértelműen elkülöníthető volt egymástól, amit a markeranalízis is alátámasztott. A morfológiai tulajdonságok közel 50 \%ában tapasztaltunk eltérést, míg az allélegyezőség mértéke nem érte el ezt az értéket: csupán 7 lókusz 1-1 allélja volt azonos. A dendrogramokon is két külön klaszterbe kerültek. A 'Simonffy piros' fragmentumhossz adatai egy lókusz kivételével (pár bp különbségtől eltekintve) megegyeznek a Wichman et al. (2007, 2010) által közöltekkel. A 'Cigány alma' több lókuszán 3 allélt detektáltunk, míg a 'Simonffy piros' diploidnak bizonyult mind a saját, mind pedig Wichman et al. (2007, 2010) és Halász et al. (2011) vizsgálataiban.

Holler et al. (2012) 12 különböző termőhelyről (köztük Magyarországról, a soroksári génbankból is) begyüjtött 'Simonffy piros' ('Roter von Simonffy') és 'Cigány alma' ('Zigeunerapfel') minták gyümölcsmorfológiai és DNS vizsgálatát végezték el, az általunk küldött 'Simonffy piros' mintát összehasonlító fajtának tekintve. Egy ausztriai minta kivételével az összes vizsgált minta azonosnak bizonyult. Holler et al. (2012) utaltak rá, hogy Felső-Ausztriában elterjedt egy 'Cigányalma' ('Mostzigeuner') néven ismert fajta, amit Bernkopf (1989 cit. Holler et al. 2012) is jellemzett, és a 'Simonffy piros'-tól eltérő jellegekkel bír. A markeranalízis során azt tapasztalták, hogy a 'Cigány alma' genetikai ujjlenyomata megegyezik a Németországban széleskörüen elterjedt 'Roter Stettiner' 
fajtáéval. A Lucas (1875a) által közölt ábrát és leírását megnézve nem kizárt, hogy azonos fajtáról van szó. Különösen azért, mert Bereczki (1887) szintén jellemzett egy fajtát 'Czigány alma' néven, amelyet német származásúnak írt le, ahol 'Brauner Matapfel' néven ismert. A Lucas (1875a) által jellemzett 'Brauner Matapfel' és a 'Roter Stettiner' viszont hasonló, de nem azonos. A 'Roter Stettiner' szinonim nevei között - ugyan kérdőjellel megjelölve -, de említi a 'Matapfel' nevet. Ezek ismeretében, és a morfológiai leírásuk alapján lehetséges, hogy a gyüjteményünkben fellelhető, Bereczki által is jellemzett 'Cigány alma' a 'Roter Stettiner' fajtával azonos.

Viszont Stoll (1888) Osztrák-Magyar Pomológia címü művében a 'Roter Stettiner' magyar neveként a 'Török Bálint'-ot adja meg, ami némi bizonytalanságra ad okot. Bereczki (1877) a 'Török Bálint' származásához azt írta, hogy régi, bizonytalan, általában német eredetünek, a 'Roter Stettiner'-rel azonosnak tartják a világ nevesebb gyümölcsészei, de semmi bizonyos adatot nem jegyeztek föl a német eredetre vonatkozóan, mind magyar, mind német területeken elterjedt ez a fajta. A magyar köznyelv szerint a 'Török Bálint' fajtát a törökök hozták magukkal hazánkba. Ezzel szemben Surányi (2002) szerint egy német eredetü fajta hazai szelekciójából származik.

Az SSR adatok alapján készített dendrogramon látszik, hogy a 'Cigány alma' és a 'Török Bálint' egymáshoz közel helyezkedik el. Az általunk vizsgált 'Cigány alma' és 'Török Bálint' allélösszetételét összevetve azt tapasztaljuk, hogy a 'Török Bálint' alléljai 100 \%-ban megtalálhatók a 'Cigány alma' genotípusában (⒍ táblázat). A közös allélokon kívül a 'Cigány alma'-nál négy lókuszon plusz egy allélt detektáltunk, ami ennek a fajtának a triploid voltát valószínüsíti, amit Holler et al. (2012) vizsgálatai is megerősítettek. A fenotípus (gyümölcsküllem) és a ploidszint alapján kizárt, hogy a két fajta azonos.

36. Táblázat. A Török Bálint és a Cigány alma azonos alléljai

\begin{tabular}{lccc}
\hline Primer & $\begin{array}{c}\text { Cigány alma } \\
\text { (utód) }\end{array}$ & $\begin{array}{c}\text { Török Bálint } \\
\text { (Q vagy } \text { đ) }\end{array}$ & Dániel féle renet \\
\hline CH01f02 & $170: 180: 188$ & $170: 180$ & $170: 180: 188$ \\
CH01h01 & $112: 116$ & $112: 116$ & $112: 116$ \\
CH02c02a & $129: 157$ & $129: 157$ & $129: 157$ \\
CH02c09 & $231: 239$ & $231: 239$ & $231: 239$ \\
CH05e03 & $162: 172$ & $162: 172$ & $162: 172$ \\
CH04e03 & $197: 205$ & $197: 205$ & $197: 205$ \\
CH05d11 & $175: 187$ & $175: 187$ & $175: 187$ \\
CH03g07 & $120: 126: 170$ & $120: 126$ & $120: 126: 170$ \\
CH02c11 & $216: 220$ & $216: 220$ & $216: 220$ \\
CH02d08 & $211: 217: 255$ & $211: 217$ & $211: 217: 255$ \\
CH03a02 & $135: 145$ & 135 & 135 \\
CH05c04 & $179: 207$ & $179: 207$ & $179: 207$ \\
\hline
\end{tabular}


A szakirodalom és a genetikai ujjlenyomatuk alapján inkább az valószínűsíthető, hogy a két fajta rokonságban áll egymással, mégpedig szülő-utód kapcsolatról lehet szó. Feltételezhető, hogy a 'Török Bálint' az egyik szülő, a 'Cigány alma' az utód. Az ivarsejtek képződésekor nem történt szabályos meiózis, így a megtermékenyítésben részt vevő petesejt vagy a hímivarsejt kettős kromoszómaszerelvénnyel rendelkezett. Ez akkor jöhetett létre, hogy a meiózis első osztódása volt szabálytalan, vagyis nem a homológ kromoszómák váltak szét, hanem valamennyi kromoszóma kromatidái kerültek a két leánysejtbe. A haploid és diploid gaméták egyesüléséből keletkezhetett a triploid fajta.

A ‘Cigány alma’ lehetséges származása:

'Cigány alma' = 'Török Bálint' $\times$ ismeretlen;

'Cigány alma' = ismeretlen $\times$ 'Török Bálint' .

Ha elfogadjuk Holler et al. (2012) megállapítását, hogy a 'Cigány alma' azonos a 'Roter Stettiner'-rel, akkor:

'Roter Stettiner $=$ 'Török Bálint' $\times$ ismeretlen;

'Roter Stettiner $=$ ismeretlen $\times$ 'Török Bálint'.

A másik elmélet, hogy a 'Török Bálint' öntermékenyülésével keletkezett a 'Cigány alma'. Abban az esetben, ha idegentermékenyüléssel keletkezett a 'Cigány alma', akkor az ismeretlen szülőnek 8 SSR lókuszban egyeznie kellett a másik szülővel, a 'Török Bálint'-tal, aminek kicsi a valószínüsége.

A fajták genetikai ujjlenyomata alapján készített dendrogramon jól látszik a 'Dániel féle renet' és a 'Cigány alma' hasonlósága. Allélösszetételük elemzésekor azt tapasztaltuk, hogy csupán egyetlen allélban különbözik a két fajta (36. táblázat). Hazai szakirodalomban nem található a 'Dániel féle renet'-ről leírás. Diel (1832) 'Dániel piros téli renete' ('Daniels rothe Winterreinette') néven ismertetett egy német (kölni) fajtát, ami Daniel államtanácsos kertjében nőtt. A leírás és a markeranalízis alapján nem kizárt, hogy ez a fajta azonos a 'Roter Stettiner', azaz az általunk 'Cigány alma'-ként ismert fajtával. A morfológiai hasonlósági dendrogramon is viszonylag közel helyezkedik el a két fajta, de nem mutat 100 \%-os egyezést. A soroksári gyüjteményben éppen egymás mellett van a két fajta, így még könnyebb az összevetésük. Szembetünő különbség van a fa habitusa és termőképességük között. A ‘Cigány alma’ elterülö, és igen gyenge termőképességü, míg a 'Dániel féle renet' lehajló habitusú, ritkább koronát nevel, és igen bőtermő. Tehát a két fajta azonossága nem jelenthető ki. További SSR markerek alkalmazása és részletes morfológiai megfigyelés lenne célszerü az azonosság vagy különbözőség meggyőző megállapítása érdekében. 


\section{Entz rozmaring - Húsvéti rozmaring - Honti alma}

Sokak által szinonimaként ismert és használt az 'Entz rozmaring' és a 'Húsvéti rozmaring'. Más szerzők a 'Honti alma'-t is az előző kettő szinonimájaként ismertetik (Herszényi 1934, Molnár 1898b). Az 'Entz-féle rozmarin' elnevezés Bereczki Mátétól (1884) származik, aki 'Magyar rozmaring' néven Entz Ferenctől oltóvesszőt kapott, de nem találta fajtaazonosnak, így a tiszteletére elnevezte róla a fajtát. Herszényi (1934) szerint a 'Honti alma' valószínüleg Hont megyéből származik. A 'Húsvéti rozmaring’-ról Brózik és Régius (1957) azt írja, hogy hazai eredetű, származásáról nem tudunk biztosat. Molnár (1898b) az 'Entz-féle rozmarin' társneveiként ismerteti a 'Honti alma'-t. Angyal (1926), Herszényi (1934) és Brózik és Régius (1957) a három fajtát szinonimának tartja. Brózik és Régius (1957) a 'Húsvét rozmaring' társneveiként felsorolja az 'Entz rozmaring'-ot is, de a származásra vonatkozó részben leírja, hogy az alaki és biológiai különbségek alapján mindkettőt külön fajtának kell tekinteni. Angyal Dezső (1926) megjegyzi, hogy valakinek rendet kellene tenni a rozmaringok között, mindazonáltal nincs egységes véleménnyel a fajták azonosságát illetően (Herszényi 1934). A Kerekes (1937) által szerkesztett Pomológia címü gyüjteményes füzetben a bevezetésben Rapaics (1937) az almafajták csoportosításánál a Rozmaringalmák csoportjában példaként az 'Entz és a 'Húsvéti rozmaring'-ot hozza fel, míg a fajták ismertetésénél Horn (1937) már csak a 'Húsvéti rozmaring'-ot ismerteti, és nem adja meg a társneveit. Herszényi (1934) számos jeles korabeli pomológus egymásnak ellentmondó véleményét közli a Gyümölcsfajta ismertetés címü müvében. Kovács Ferencet idézi, aki szerint a 'Húsvéti rozmaring' „föleg abban különbözik az Entz-rozmaringtól, hogy nem olyan csúcsos az alakja, annál nagyobb, világos zöldessárga alapon nagyobb a piros folt a napos oldalon és később, február-májusban érik'. A 'Húsvéti rozmaring'-ról nem ad külön jellemzést, hanem utal az 'Entz-féle rozmaring'-ra, és megjegyzi: „Célszerü volna, ha a szaksajtó az Entz-féle rozmarin, a Honti alma s a Húsvéti rozmaring almafajták kérdését, Angyal Dezső nagynevü tudósunk véleménye, illetve kívánsága szerint véglegesen rendezné".

Morfológiai vizsgálatainkba csak a 'Húsvéti és az 'Entz rozmaring'-ot, míg a markeranalízisbe a 'Honti alma'-t is bevontuk. Az utóbbihoz mindegyik fajtából két különböző termőhelyröl származó minta állt rendelkezésünkre, de mivel ezek azonos allélmintázatot adtak, a továbbiakban nem említjük a termőhelyi származást. Az igen hasonló morfológiai bélyegekkel rendelkező 'Entz rozmaring' és 'Húsvét rozmaring' genetikai ujjlenyomata $100 \%$-ban megegyezett (ㄱ. táblázat). A 'Honti alma' 10 lókusz egy-egy allélja mutatott azonosságot a másik két fajtával, ezért vélhetően szülö-utód, vagy testvéri rokonságban vannak, de ezt a dendrogram nem tükrözi. A 'Honti alma' és a két Rozmaring 
közötti testvéri rokonság nem lehetetlen, de elhanyagolható a valószínüsége a szülő-utód kapcsolathoz képest.

A két Rozmaring fajta SSR markerekkel történő elkülönítése nem sikerült, de a kismértékủ morfológiai eltérés miatt célszerü lenne más markerezési módszert is alkalmazni annak érdekében, hogy valóban azonos fajtákról, vagy rügymutációval keletkezett fajtákról van szó. A 'Honti alma' viszont nem szinonimája egyik vizsgált rozmaringnak sem. Ezt igazolják Tóth et al. (2007) megfigyelései is, akik szerint a 'Honti alma' gyümölcsmérete kisebb, gyümölcsalakja kevésbé megnyúlt, fája szétterülőbb a 'Húsvéti rozmaring'-énál.

37. Táblázat. Az Entz rozmaring, Húsvéti rozmaring és a Honti alma allélösszetétele (a Honti almánál színnel kiemeltük a két Rozmaringban is megtalálható allélokat)

\begin{tabular}{lccc}
\hline Primer & Entz Rozmaring & Húsvéti rozmaring & Honti alma \\
\hline CH01f02 & $170: 184$ & $170: 184$ & $170: 180$ \\
CH01h01 & 112 & 112 & $114: 118: 130$ \\
CH02c02a & $171: 185: 191$ & $171: 185: 191$ & $141: 185$ \\
CH02c09 & $243: 247: 253$ & $243: 247: 253$ & $231: 241: 243$ \\
CH05e03 & $162: 172: 190$ & $162: 172: 190$ & 162 \\
CH04e03 & $193: 197: 203$ & $193: 197: 203$ & $197: 211$ \\
CH05d11 & $187: 195: 205$ & $187: 195: 205$ & $169: 175: 177$ \\
CH03g07 & $116: 124: 126$ & $116: 124: 126$ & $126: 166$ \\
CH02c11 & $222: 232$ & $222: 232$ & $222: 232: 236$ \\
CH02d08 & $211: 217: 247$ & $211: 217: 247$ & $217: 253$ \\
CH03a02 & $135: 145$ & $135: 145$ & $135: 155$ \\
CH05c04 & $185: 207$ & $185: 207$ & $185: 205: 259$ \\
\hline
\end{tabular}

\section{További lehetséges fajtaazonosságok}

A hasonló morfológiai bélyegekkel rendelkező 'Nyári fontos' és 'Tordai alma' allélösszetétele 100 \%-os egyezést mutatott. Ez meglepő, mert a két fajta hasonlóságára nem találtunk a szakirodalomban megjegyzést. A 'Nyári fontos' eredete nem tisztázott, egyes szerzők szerint magyar, mások szerint francia (Brózik és Régius 1975). Bereczki (1882) Leroy francia pomológust idézi, aki szerint Amiensban 'Nyári fontos' (=Rambour d'été) név alatt, már 1535-ben ismeretes volt. A 'Tordai alma' csak Bereczki (1887) rövid jellemzéséből ismert, más szakirodalomban nem található meg. Mivel Bereczki „szelíden bordásfelületü’-nek jellemzi, az általa 'Káposzta alma' elnevezéssel is illetett és a gyüjteményünkben megtalálható, az Angol Nemzeti Fajtagyüjteményből származó 'Tordai alma’ valószínüleg nem azonos. A szakirodalmi jellemzések alapján a gyüjteményünkben megtalálható ‘Tordai alma' valójában a 'Nyári fontos', amit a morfológiai és molekuláris markerezési eredményeink is alátámasztanak, tehát a két fajta nem szinonima, hanem fajtakeveredésről van szó. 


\subsection{Az SSR markerek és az UPOV bélyegek alkalmassága a fajtaazonosítás során}

Önmagában a fenotípusra irányuló vizsgálatok eredményeit nem tekinthetjük mindig egyértelműnek. Több éves vizsgálat szükséges ahhoz, hogy kiszürjük a környezeti tényezők fenotípusra gyakorolt hatását. A fenotípus vizsgálatok objektív elvégzéséhez rendelkezni kell a kontroll fajtákkal, ami gyakran nem megvalósítható. Ezért más termőhelyről származó adatokat kell felhasználni, vagy jelentős szubjektivitást kell alkalmazni, ami rontja a vizsgálatok minőségét. Federico et al. (2008) a morfológiai és molekuláris adatmátrixok között különbséget találtak, ami felhívja a figyelmet arra, hogy a morfológiai tulajdonságokat jelentősen befolyásolhatják a környezeti hatások, míg a molekuláris markerek függetlenek a környezettől.

Fajtaazonosításra és genetikai diverzitás vizsgálatokra alkalmasnak tartják az SSR markereket, de néhány esetben a megbízhatóságuk megkérdőjeleződik. Ennek egyik példája a rügymutációval létrejött fajták elkülöníthetősége. A rügymutációval keletkezett fajták (mint például a vizsgálatokban szereplő 'Batul' alapfajta és a 'Mosolygós batul') SSRujjlenyomatának azonossága nem feltétlen jelenti azt, hogy azonos fajtákról van szó, hiszen a rügymutációval keletkezett fajták csak egy vagy néhány kisebb régióban különböznek, amelyek pl. a gyümölcs színeződéséért felelősek. Az SSR markereket a rügymutációval keletkezett fajták elkülönítésére eddig sikertelenül alkalmazták (Gianfranceschi et al. 1998, Hokanson et al. 1998, Galli et al. 2005, Gasi et al. 2010, Patzak et al. 2012). A rügymutációval keletkezett fajták (feltételezhetően a 'Batul' fajták is azok) elválasztásához nagyobb polimorfizmussal rendelkező markerek szükségesek, mint például retrotranszpozonok, amelyekkel Venturi et al. (2006) és Zhao et al. (2010) már sikeresen megkülönböztették a 'Gala', 'Braeburn' és 'Fuji' fajtákat. Galli et al. (2008) viszont ugyanezzel a technikával csak a 'Jonathan' alapfajtát tudta a többi 'Jonathan' fajtától elkülöníteni.

A vizsgálatainkban további példákat is találtunk a sikertelen elkülönítésre a fajták genetikai ujjlenyomata alapján. Az SSR adatok kielemzésekor (mind az Identity, mind a dendrogram alapján) felfigyeltük két fajtapárosra. A 'Gegesi piros' és a 'Sikulai' 100 \%-ban azonos allélösszetétellel rendelkezik. A morfológiai dendrogramon is közel helyezkednek el, de számos tulajdonságban találunk legalább egy kifejeződési fokozat eltérést. Az UPOV értékelési rendszere szerint két fajta között akkor van világos különbség, ha legalább egy tulajdonságban legalább egy kifejeződési fokozat eltérés van. Ennek értelmében a 'Gegesi piros' és a 'Sikulai' megkülönböztethető, tehát nem azonos egymással. A két fajta genotípus szerinti sikeres elkülönítésének érdekében további SSR markerek vagy egyéb markerezési eljárások alkalmazása szükséges. A ‘Csíkos óriás halasi’ és a 'Vajki alma’ allélösszetétele 
szintén 100 \%-ban megegyezik. Ezt az egyezést a morfológiai vizsgálatok nem támasztották alá, a dendrogramon is teljesen külön főklaszterbe kerültek. A két fajta sikeres elkülönítése érdekében további SSR lókuszok vizsgálatát kell elvégezni. Halász et al. (2011) bizonyította, hogy a 'Vajki alma' tetraploid, és ugyanez valószínüsíthető a 'Csíkos óriás halasi' esetében is. A duplikáción átesett genomokra jellemző az instabilitás, megnő a kisebb-nagyobb volumenű kromoszomális átrendeződések, módosulások valószínűsége. A duplikált gének (különösen a dózisérzékeny gének) expressziója nagymértékben módosulhat véletlenszerüen, illetve genetikai és epigenetikai szabályozás hatására, ami jelentős fenotípusos varianciát idézhet elő (Wang et al. 2004).

A morfológiai (főként UPOV és IPGRI) leírások pontosítása érdekében számos kutató (Szalatnay et al. 2009, Pereira-Lorenzo et al. 2003, 2007, Santesteban et al. 2009) használta a molekuláris markereket. Hokanson et al. (2001) és Goerre (2001) is felhívták a figyelmet arra, hogy a pontosabb eredmények érdekében a molekuláris adatokat célszerü kombinálni a morfológiai és egyéb fenotípusos tulajdonságokkal. Ezt a saját vizsgálataink is alátámasztják a fenti két fajtapáros példáján.

\subsection{A morfológiai és molekuláris adatok közti összefüggés}

Saját vizsgálatainkban a Mantel-teszt szignifikáns, közepes erősségü korrelációt ( $r=0,33343$, $p=0,00000)$ mutatott ki a morfológiai és a molekuláris adatmátrixok között, ami hasonló Giancola et al. (2002) szójánál kapott eredményéhez ( $r=0,353)$. Khoufi et al. (2012) durumbúzafajták morfológiai (UPOV) és molekuláris (SSR) adatai között gyenge korrelációt $(r=0,24)$ tapasztaltak. Ezzel szemben Guarino et al. (2006) és Gasi et al. (2010) ( $r=0,095$; $p>0,05)$ alma, Tommasini et al. (2003) repce $(r=0,098, p=0,283)$ fajták vizsgálatakor a Mantel-teszttel nem talált korrelációt a morfológiai (UPOV) és molekuláris (SSR) adatok között. Mivel a szakirodalomban fellelhető morfológiai és molekuláris távolság mátrixok nem minden esetben mutattak korrelációt, a fajtajellemzéshez és rokonsági vizsgálatokhoz javasoljuk a fenotípusos jellemzés genotípus vizsgálatokkal kombinálását kis számú ( 10), nagy polimorfizmussal rendelkező SSR markerrel. 


\section{7. ÚJ TUDOMÁNYOS EREDMÉNYEK}

1. Meghatároztam 57 régi almafajta illetve genotípus virágzási idejét, és a virágzás kezdete és a fővirágzás időpontja alapján virágzási időcsoportokba soroltam őket.

2. Elkészítettem 73 Kárpát-medencében elterjedt régi almafajta illetve genotípus mikroszatellit ujjlenyomatát és 60 fajta UPOV TG/14/9 szerinti számkulcsos jellemzését.

3. Párhuzamosan végzett fenotípus- és genotípusvizsgálatokkal jellemeztem a kárpátmedencei almafajták genetikai variabilitását. Azt tapasztaltam, hogy:

a. a vizsgált régi fajták genetikai variabilitása nagyobb az üzemi fajtákénál (a szakirodalomban fellelhető heterozigótasági értékek alapján).

b. a Sóvári és Renet fajtacsoportokon belül is nagy diverzitás tapasztalható.

c. a molekuláris és a morfológiai adatmátrixok alapján készített dendrogram nem tükrözi a földrajzi eredetet.

4. A fajtaazonosításra irányuló fenotípus és SSR vizsgálatok eredményeként megállapítottam, hogy:

a. a 'Zöld batul' nem mutat közvetlen rokonságot a 'Batul' fajtával, hanem feltételezhetően az alapfajta távoli leszármazottja. Ezért a jövőben ezt a fajtát külön fajtaként kell nyilvántartani.

b. a 'Beregi sóvári' kárpátaljai és az Angol Nemzeti Fajtagyüjteményben megőrzött genotípusa nem azonos. Bebizonyosodott, hogy a kárpátaljai egyezik meg a Bereczki Máté által leírt fajtával, ezért az Angol Nemzeti Fajtagyüjteményben található egyedet ismeretlen genotípusnak kell tekinteni.

c. a szinonimának tartott 'Nemes sóvári és az Angol Nemzeti Fajtagyüjteményben fenntartott 'Sóvári nobil' nem azonos.

5. Allélösszetétele alapján három fajta esetében alátámasztottam, vagy cáfoltam a szülő utód kapcsolatokat.

a. A 'Fertődi téli' apai partnere nem lehet a nemesítő által közölt 'Török Bálint'. Ennek megfelelően a származás helyes közlési módja:

'Fertödi téli' = 'Jonathan' $\times$ ismeretlen.

b. A 'Budai Domokos' nemesítő által közölt szülőfajtái ('Téli arany parmen', 'Jászvadóka') nem mutattak $100 \%$-os allélegyezést a vélt utóddal, így a származása ismeretlennek tekintendő.

c. A 'Cigány alma' és a 'Török Bálint' fajták között szülö-utód kapcsolat van. A valószínűsíthető származás: 'Cigány alma' = 'Török Bálint' $\times$ ismeretlen vagy 
'Cigány alma' = ismeretlen $\times$ 'Török Bálint'. Valószínüsíthető, hogy a 'Cigány alma' a 'Török Bálint' öntermékenyülésével keletkezett.

6. A 'Csíkos óriás halasi' és a 'Vajki alma' 12 SSR lókuszon 100 \%-ban megegyezett, de a fenotípus alapján biztos nem azonos fajtákról van szó. Ez alátámasztja a duplikáción átesett genomok (poliploid fajták) instabilitását. 


\section{8. ÖSSZEFOGLALÁS}

Az alma a mérsékelt égöv legjelentősebb gyümölcsfaja. Több ezer fajta ismert világszerte, de a termesztésben alig pár tucat fajta található. A termesztett fajták genetikai variabilitása beszükült, gyakran azonos szülőfajtákkal rendelkeznek, ami a biotikus és abiotikus hatásokkal szemben érzékenyebbé teszi a fajtákat. A piacon megtalálható fajták színválasztéka széles, de az alak és a beltartalmi értékek tekintetében már kisebb a változatosság.

A biodiverzitás fenntartására irányuló törekvések felhívják a figyelmet arra, hogy nemcsupán a vadon termő, hanem a kultúrnövények esetében is szükség van a fajok, fajták védelmére, megörzésére és felhasználására. Egyre több állami vagy magánkézben levő gyümölcsgénbank létesül világszerte, viszont a növényanyag értékelésére - elsősorban a szakértelem, idő, munkaerő és pénz hiánya miatt - már csak a nagyobb gyüjteményekben van lehetöség.

Kutatásainkban a Budapesti Corvinus Egyetem Gyümölcstermő Növények Tanszék génbanki gyüjteményében vizsgáltuk a Kárpát-medencében keletkezett és/vagy elterjedt régi almafajták fenológiai és morfológiai jellemzöit. A fenotípusos vizsgálatokat kiegészítettük a genotípus alapú markerezéssel. Kiemelt célunk volt a fajták számkulcsos jellemzése, és egyedi genetikai ujjlenyomatuk elkészítése. A vizsgálatokban szereplő fajták körülbelül háromnegyede a Kárpát-medence valamelyik tájegységén létrejött endemikus fajta. A legtöbb fajta Erdélyből származik, de Magyarország valamennyi tájegységén (Kárpátalja, Felvidék, Délvidék, Dunántúl, Alföld) keletkezett fajta megtalálható a vizsgálatban. Néhány külföldi vagy vitatott származású fajtát is bevontunk a vizsgálatokba, mert ezek nagy jelentőséggel bírnak a korábbi évszázadok hazai fajtahasználatában. A molekuláris és a morfológiai adatmátrixok alapján készített dendrogramokon kialakult csoportok azonban nem tükrözték a földrajzi származást.

A virágzási időszak a vizsgálati évek többségében április 15-e elött vagy után pár nappal kezdődött, és 14-26 napig tartott az időjárástól függően. A hosszabb virágzási időszakú években jobban elkülönültek az egyes virágzási időcsoportok, míg a gyors virágzású években csak pár nap különbség volt megfigyelhető a csoportok között. A virágzásfenológiai megfigyeléseink alapján elkészítettük a virágzási időcsoportokat. Mind a virágzás kezdete, mind pedig a fövirágzás alapján besoroltuk a fajtákat. A virágzási idő kezdete genetikailag kódolt, a fajtára jellemző, így megbízhatóan alkalmazható. A gyakorlatban viszont a fővirágzás időpontja határozza meg a fajtatársítás sikerességét, így szükség van az így kialakított virágzási időcsoport ismeretére. A legjelentősebb eltérést a 
kétféle csoportosítási mód között a közepes és a kései virágzású fajták esetében tapasztaltuk. A legtöbb vizsgált fajta közepes vagy kései virágzási csoportba került. Eddigi megfigyeléseink alapján az igen korai, korai és az igen kései virágzású fajták stabil virágzási idejünek tekinthetők, viszont a középidejü és a kései virágzású fajták többségénél további vizsgálati évek szükségesek a virágzási időcsoportba való pontos besoroláshoz. Eredményeink a gyakorlat számára is hasznosíthatók, de figyelembe kell venni a termőhelyi adottságokból bekövetkező korábbi, illetve későbbi virágzás lehetőségét.

A fajták fenotípusának jellemzését az UPOV irányelvei szerint végeztük, a vegetatív és a generatív szervek tulajdonságai alapján, összesen 56 tulajdonságot figyelembe véve. A DUS-tesztek során is alkalmazott számkulcsos leírás lehetőséget ad a fajták gyors és egységes jellemzésére. Vizsgálataink eredményeként 60 régi, főként magyar almafajtát írtunk le számkulcsokkal.

A genotípus jellemzését 12, nagy polimorfizmust mutató SSR markerrel végeztük. A felhasznált primerek közül öt megtalálható az ECPGR által fajtaazonosításra javasolt markerkörben. A felhasznált markerek mindegyike nagy polimorfizmust mutatott, így javasolhatók fajtaazonosítási célokra. Két primer (CH02d08 és CH05c04) kiértékelése nehezebb volt, mert a fragmentum-analízis során két csúcsot kaptunk, így ezek helyett a további vizsgálatokhoz ajánlott másik primert választani. Két fajtapár ('Gegesi piros’ és 'Sikulai', valamint 'Csíkos óriás halasi’ és 'Vajki alma') 100 \%-ban azonos allélösszetétellel rendelkezik, de azonosságukat a fenotípusos vizsgálatok nem támasztották alá. Ez felhívja a figyelmet arra, hogy a genotípus vizsgálatokat célszerü fenotípusos megfigyelésekkel együtt alkalmazni magasabb ploidszintü fajták esetében. Másik lehetőség, hogy több SSR vagy jobb elválasztóképességü molekuláris markert kell a kérdéses fajtáknál alkalmazni. A Batul vélhetően rügymutációval keletkezett fajtáinak elkülönítése nem volt egyértelmü, így ezeknél más (nem SSR) molekuláris technikát kell alkalmazni. Megfigyeléseink szerint a fajták ploidszintjét az SSR markerek alapján nehéz megállapítani. Abban az esetben, ha minden lókuszon két allélt kaptunk, valószínűsíthető, hogy a fajta diploid. Ezzel szemben, ha három allélt detektáltunk, az nem feltételen jelenti, hogy a fajta triploid. A 'Fekete tányéralma' és a 'Szabadkai szercsika' példája ezt alátámasztja, mert jelentős arányban mutattak három alléllal rendelkező lókuszokat, de a flow citométeres és keresztezési vizsgálatok alapján diploidnak kell tekintenünk a két fajtát. A másik eset a 'Vajki alma' példája, amikor több lókuszon három allélt detektáltunk, de flow citométeres mérések szerint tetraploid fajtáról van szó.

Származás vizsgálatára kiválóan alkalmasnak találtuk az SSR markerezést. Nemcsak az ismert származású fajták származását tudtuk az SSR adatok alapján alátámasztani vagy 
megcáfolni. A vonatkozó szakirodalmi leírások alapján elindulva a 'Cigány alma' és a 'Török Bálint' fajták közötti szülő-utód kapcsolatot is bizonyítani tudtuk, amely kérdés évtizedek óta nyitott volt.

A fenotípus és genotípus vizsgálati módszerek alapján megállapíthatjuk, hogy a vizsgált gyüjtemény nagyfokú diverzitást mutatott. A néhány tévesen dokumentált fajta, és a 'Batul' és 'Kanadai renet' fajtákon kívül az összes fajta nagy genetikai távolságot mutatott, ezért a nemesítés során kiváló génforrások lehetnek, különösen akkor, ha rendelkeznek valamilyen fokú, kórokozóval szembeni rezisztenciával. 


\section{SUMMARY}

The apple is the most important fruit species of temperate zone. More thousands apple varieties are known worldwide, but some dozens are in the production barely. Genome of grown cultivars didn't show high variability, because they often have same parents, therefore they can be sensitive to biotic and abiotic environmental effects. The color range of cultivars, which are on the market, is large, however there is less variability in their shape and inner content value.

Efforts to biodiversity's maintenance call our attention that it is necessary to protect, save, and use not only the wilding plants' species and varieties, but the grown plants as well. More and more ex-situ fruit gene banks, belong to the state or private sector, have been established all over the world, however accessions are evaluated just in the largest collections due to lack of suitable knowledge, time, labor and financial support.

Phenological and morphological traits of apple cultivars, which are native or widespread in the Carpathian basin, were studied in the frame of this research in the gene bank of Corvinus University of Budapest's Department of Pomology. The phenotypic observations were added to markeranalysis. Our highlighted aim was to characterize the varieties using UPOV descriptors and to create their fingerprints. Three-fourth parts of the examined varieties were endemic varieties from different regions of Carpathian basin. The most varieties were from Transylvania and other Hungarian regions (Transcarpathia, upper Hungary, Autonomous Province of Vojvodina, Transdanubia, Great Plain). Some varieties with foreign or disputed origin can be also found among the examined varieties because these cultivars had an important role in the Hungarian cultivar usage in the past centuries. The geographical origin wasn't mirrored on the dendrograms' groups, which were made basis of molecular and morphological data matrix.

The blooming period was started before 15th April or some days later in the bulk of examined years and it fulfilled between 14th and 26th April depended on the weather conditions. In the examined years with long blooming period there were differences in the blooming groups, while there were just some days difference in the blooming time between the groups in the years with short blooming period. Blooming groups, which were determined based on our observations, were created, both beginning of blooming and main blooming were noticed so as to group the examined varieties. Beginning of blooming is encoded by genes, this characteristic is typical for the variety, so this method can be used trustworthy. Success of growing is based on main blooming times in the practice, so knowledge of blooming groups is necessary for pollination. The largest difference between 
examination of beginning and main blooming time was noted in the case of medium and late blooming varieties. The most varieties were in the medium or late blooming groups. Based on our results the varieties with very early, early, and very late blooming time had stabile blooming period, but more data are needed for the most medium and late blooming cultivars to determine their exact blooming group. Our results can be used by the practice, but we have to take into consideration the possibility of previous and delayed blooming time because of site conditions.

Phenotypic characterization was made using UPOV descriptions. 56 different characters were examined based on the vegetative and generative traits of the organs. The number-based system gives a possibility to describe the varieties rapidly and uniformly during the DUS tests. As results of this research 60 historic apple varieties having mainly Hungarian origin were marked with numbers.

The genotype was characterized by twelve SSR markers showing high polimorphism. Five of twelve used primers could be found among standard set for variety identification

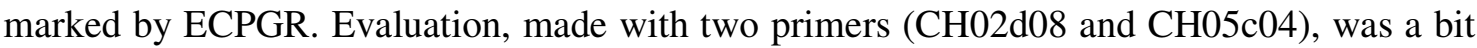
difficult, because two peaks were got during the fragment analysis, so two other primers were chosen for further examinations instead of named. Two cultivar couples (Gegesi piros' and 'Sikulai' as well as 'Csíkos óriás halasi' and 'Vajki alma') had the same alleles, this similarity wasn't supported by phenotypic examinations. This result is a good example that genotype examinations have to make together with phenotypic observations. Other possibility is to use more SSR markers or other type of marker analysis with better separation capacity in the case of questionable varieties. Other molecular marker was used during differentiation of 'Batul' clones, because SSR didn't give suitable results.

Ploidy level of varieties can't determine using SSR. If there were two alleles in all loci, this variety may be diploid. On contrarily, if three alleles were detected, it doesn't mean, that the sample was from a triploid variety. For instance, 'Fekete tányéralma' and 'Szabadkai szercsika' are good examples, because number of loci with three alleles was significant, however both varieties may be diploid because of flow cytometry measurements and cross breeding results. Otherwise, three alleles are often detected in loci of 'Vajki alma', but this variety is tetraploid because of flow cytometry measurement.

The SSR marker is an excellent method to determine origin of varieties. Not only varieties with known origin can be confirmed or traversed. Starting from the literature data parent - progeny relationship was confirmed between 'Cigány alma' and 'Török Bálint' in the frame of this $\mathrm{PhD}$ research. This had been an open question for many decades. 
The observed collection showed high genetic diversity by phenotypic and genotypic methods. There was a high genetic distance between all varieties except in the case of 'Batul' and 'Kanadai renet' as well as some mistakenly documented varieties, therefore Department of Pomology's ex-situ gene bank collection may be excellent genetic resources for the breeding, if these accessions have resistance to important apple diseases. 


\section{MELLÉKLETEK}

1. melléklet. Irodalomjegyzék

1. Angyal D. (1926): Gyümölcsismeret. (Pomológia) Budapest: Pátria Irodalmi Vállalat és Nyomdai Rt., 524. p.

2. Baric S., Storti A., Hofer M., Dalla Via J. (2012): Resolving the parentage of the apple cultivar 'Meran'. Erwerbs-Obstbau, 54:143-146.

3. Bassil N., Hummer K. E., Postman J. D., Fazio G., Baldo A., Armas I., Williams R. (2009): Nomenclature and genetic relationships of apples and pears from Terceira Island. Genet Resour Crop Ev, 56:339-352.

4. Beach S. A., Booth N. O., Taylor O. M. (1905): The Apples Of New York. I. kötet. Albany: J. B Lyon Company, 409. p.

5. Benham J. (2001): Genographer 1.6. http://hordeum.oscs.montana.edu/genographer.

6. Bereczki M. (1877): Gyümölcsészeti vázlatok I. Kötet. Arad: Gyulai István nyomdája, 510. p.

7. Bereczki M. (1882): Gyümölcsészeti vázlatok II. Kötet. Arad: Gyulai István nyomdája, 517. p.

8. Bereczki M. (1884): Gyümölcsészeti vázlatok III. Kötet. Arad: Gyulai István nyomdája, 549. p.

9. Bereczki M. (1887): Gyümölcsészeti vázlatok IV. Kötet. Arad: Gyulai István nyomdája, 541. p.

10. Blazek J., Krelinová J. (2011): Tree growth and some other characteristics of new columnar apple cultivars bred in Holovousy, Czech Republic. Hortic Sci (Prague). 38(1):11-20.

11. Bodor P., Gál M., Tóth M. (2008): Floral phenology investigation of scab resistant apple varieties and multi-resistant candidates - bred in Hungary - in 2007-2008. Int J Hortic Sci, 14(4):7-10.

12. Bodor P. (2009): Betegség-ellenálló almafajták és fajtajelöltek virágzás-fenológiai és termékenyülés-biológiai sajátosságai. Doktori $(\mathrm{PhD})$ értekezés. Budapest

13. Bordeianu T., Constantinescu N., Péterfi S., Stefan N., Anghel G., Costetch M., Cvasnii D., Miron G., Oros F., Pompeius E., Trandafir V. (1964): Pomologia Republicii populare Romine II. kötet. Bucarest: Acad. R.P.R. 1007. p.

14. Bouvier, L., Lespinasse, Y. and Schuster, M. 2000. Karyotype analysis of an haploid plant of apple (Malus $\times$ domestica). Acta Hortic, 538:321-324.

15. Bödecs L-né, Tomcsányi P. (1979): Alma. 36-82. p. In: Tomcsányi P. (szerk.). Gyümölcsfajtáink. Gyakorlati pomológia. Budapest: Mezőgazdasági Kiadó, 454. p.

16. Brookfield J.F.Y. (1996): A simple new method for estimating null allele frequency from heterozygote deficiency. Mol Ecol, 5:453-455.

17. Brown S. K., Maloney K. E. (2003): Genetic improvement of apple: Breeding, markers, mapping and biotechnology. 31-59. p. In: Ferree D. C. és Warrington I. J. (szerk.). Apples. Botany, Production and Uses. New York: CABI Publishing, 660. p.

18. Brózik S., Régius J. (1957): Termesztett gyümölcsfajtáink 1. Almatermésüek. Alma. Budapest: Mezőgazdasági Kiadó, 25. p.

19. Brózik S. (1974): Fajtaismeret (pomológia). 22-41. p. In: Gyúró F. A gyümölcstermesztés technológiája. Budapest: Mezőgazdasági Kiadó, 734. p.

20. Brózik S., Nyéki J. (1974): Fenológia. 299-318. p. In: Gyúró F. (szerk.): A gyümölcstermesztés alapjai. Budapest: Mezőgazdasági Kiadó, 797. p.

21. Brózik S., Nyéki J. (szerk.) (1975): Gyümölcstermő növények termékenyülése. Budapest: Mezőgazdasági Kiadó, 234. p. 
22. Bunyard E. A. (1920): A handbook of Hardy fruits more commonly grown in Great Britain. Apples and pears. London: John Murray, Albemarle street, 205. p.

23. Bus V. G. M., Laurens F., van de Weg W. E., Rusholme R. L., Rikkerink E., Gardiner S., Bassett H. C. M., Kodde L. P., Plummer K. M. (2005): The Vh8 locus of a new gene-for-gene interaction between Venturia inaequalis and the wild apple Malus sieversii is closely linked to Vh2 locus in Malus pumila. New Phytol, 166:10351049.

24. Cabe P. R., Baumgarten A., Onan K., Luby J. J., Bedford D. S. (2005): Using microsatellite analysis to verify breeding records: A study of 'Honeycrisp' and other cold-hardy apple cultivars. HortScience, 40(1): 15-17.

25. Calenge F., Drouet D., Denance C., van de Weg W. E., Brisset M.-N., Paulin J. P., Durel C. E. (2005): Identification of a major QTL together with several minor additive or epistatic QTLs for resistance to fire blight in apple in two related progenies. Theor Appl Genet, 111:128-135.

26. Calenge F., Durel C. E. (2006): Both stable and unstable QTLs for resistance to powdery mildew are detected in apple after four years of field assessments. Mol Breeding, 17:329-339.

27. Cevik V., Ryder C. D., Popovich A., Manning K., King G. J., Seymour G. (2009): A FRUITFULL-like gene is associated with genetic variation for fruit flesh firmness in apple (Malus domestica Borkh.). Tree Genet Genomes, 6:271-279.

28. Chagné D., Carlisle C. M., Blond C., Volz R. K., Whitworth C. J., Oraguzie N. C., Crowhurst R. N., Allan A. C., Espley R. V., Hellens R. P., Gardiner S. E. (2007): Mapping a candidate gene (MdMYB10) for red flesh and foliage colour in apple. BMC Genomics, 8:212.

29. Clarke J. B., Tobutt K. R. (2009): A standard set of accessions, microsatellites and genotypes for harmonising the fingerprinting of cherry collections for the ECPGR. Acta Hortic, 814:615-61.

30. Conner J. P., Brown S. K., Weeden N. F. (1998): Molecular marker analysis of quantitative traits for growth and development in juvenile apple trees. Theor Appl Genet, 96:1027-1035.

31. CPVO. Community Plant Variety Office. (2006): Protocol for distinctness, uniformity and stability tests Malus domestica Borkh. Apple. CPVO-TP/14/2. 14/03/2006. http://www.cpvo.europa.eu/documents/TP/fruits/TP_014-

2_MALUS_DOMESTICA.pdf

32. Diel A. F. A. (1799): Kernobstsorten. Apfel. I. kötet. Frankfurt am Main.

33. Diel A. F. A. (1799-1816): Kernobstsorten. Apfel. I-XII. kötet. Frankfurt am Main.

34. Diel A. F. A. (1832): Kernobstsorten. Apfel-Birnen. VI. füzet. Stuttgart und Tübingen. 222. p.

35. Dunemann F., Urbanietz A., Gardiner S., Bassett H., Legg W., Rusholme R., Bus V., Ranatunga C. (2004): Marker assisted selection for Pll powdery mildew resistance in apple-Old markers for a new resistance gene. Acta Hortic, 663:757-762.

36. Dunemann, F., Schuster, M. (2009): Genetic characterization and mapping of the major powdery mildew resistance gene Plbj from Malus baccata jackii. Acta Hortic, 814:791-798.

37. Evans K. M., Fernández-Fernández F., Govan C. (2009): Harmonising fingerprinting protocols to allow comparisons between germplasm collections - Pyrus. Acta Hortic, 814:103-106.

38. Evans, K. M., Patocchi, A., Rezzonico, F., Mathis, F., Durel, C. E., FernándezFernández, F., Boudichevskaia, A., Dunemann, F., Stankiewicz-Kosyl, M., Gianfranceschi, L., Komjanc, M., Lateur, M., Madduri, M., Noordijk, Y., van de Weg, W. E. (2011): Genotyping of pedigreed apple breeding material with a 
genome-covering set of SSRs: trueness-to-type of cultivars and their parentages. Mol Breeding, 28:535-547.

39. Farrokhi J., Darvishzadeh R., Naseri L., Mohseni Azar M., Hatami Maleki H. (2011): Evaluation of genetic diversity among Iranian apple (Malus $\times$ domestica Borkh.) cultivars and landraces using simple sequence repeat markers. Aust J Crop Sci, 5(7):815-821.

40. Federico M., Busconi M., Camangi F., Fogher C., Stefani A., Sebastiani L. (2008): Ancient Pomoideae (Malus domestica Borkh. and Pyrus communis L.) cultivars in "Appenino Toscano" (Tuscany, Italy): molecular (SSR) and morphological characterization. Caryologia, 61(3):320-331.

41. Forte A. V., Ignatov A. N., Ponomarenko V. V., Dorokhov D. B., Savelyev N. I. (2002): Phylogeny of the Malus (Apple Tree) species, inferred from the morphological traits and molecular DNA analysis. Russ J Genet+, 38(10): 11501160 .

42. Galli, Zs., Halász, G., Kiss, E., Heszky, L. and Dobránszki, J. (2005): Molecular identification of commercial apple cultivars with microsatellite markers. HortScience, 40(7):1974-1977.

43. Galli, Zs., Wichmann, B., Kiss, E., Szabó, T., Heszky, L. (2008): Test of the utility of apple retrotransposon insertion patterns for molecular identification of 'Jonathan' somatic mutants. Int J Hortic Sci, 14(3):7-10.

44. Galli P., Broggini G. A. L., Kellerhals M., Gessler C., Patocchi A. (2010): Highresolution genetic map of the Rvil5 ( $V r 2)$ apple scab resistance locus. Mol Breeding, 26(4):561-572.

45. Gardiner S. E., Norelli J. L., de Silva N., Fazio G., Peil A., Malnoy M., Horner M., Bowatte D., Carlisle C., Wiedow C., Wan Y, Bassett C. L., Baldo A. M., Celton JM., Richter K., Aldwinckle H. S., Bus V. G. M. (2012): Putative resistance gene markers associated with quantitative trait loci for fire blight resistance in Malus 'Robusta 5' accessions. BMC Genet, 13:25.

46. Garkava-Gustavsson, L., Nybom, H. (2007): Genetic diversity in a collection of apple (Malus $\times$ domestica Borkh.) cultivars as revealed by RAPD markers. Int $J$ Hortic Sci 13: 1-11.

47. Garkava-Gustavsson L., Kolodinska Brantestam A., Sehic J., Nybom H. (2008): Molecular characterisation of indigenous Swedish apple cultivars based on SSR and $S$-allele analysis. Hereditas, 00:1-14.

48. Gasi F., Simon S., Pojskic N., Kurtovic M., Pejic I. (2010): Genetic assessment of apple germplasm in Bosnia and Herzegovina using microsatellite and morphologic markers. Sci Hortic-Amsterdam, 126:164-171.

49. Gessler C., Patocchi A., Sansavini S., Tartarini S., Gianfranceschi L.. (2006): Venturia inaequalis resistance in apple. Crit Rev Plant Sci, 25:473-503.

50. Gharghani A., Zamani Z., Talaie A., Oraguzie N. C., Fatahi R., Hajnajari H., Wiedow C., Gardiner S. E. (2009): Genetic identity and relationships of Iranian apple (Malus $\mathrm{x}$ domestica Borkh.) cultivars and landraces, wild Malus species and representative old apple cultivars based on simple sequence repeat (SSR) marker analysis. Genet Resour Crop Ev, 56:829-842.

51. Giancola S., Marcucci Poltri S., Lacaze P., Hopp H. E. (2002): Feasibility of integration of molecular markers and morphological descriptors in a real case study of a plant variety protection system for soybean. Euphytica, 127(1):95-113.

52. Gianfranceschi L., Seglias N., Tarchini R., Komjanc M., Gessler C. (1998): Simple sequence repeats for the genetic analysis of apple. Theor Appl Genet, 96: 10691076. 
53. Gianfranceschi L, Soglio V (2004): The European project HiDRAS: innovative multidisciplinary approaches to breeding high quality disease resistant apples. Acta Hortic, 663:327-330.

54. Girókúti P. F. (1863): Magyarország gyümölcsészete színezett rajzokban. Pest: Heckmann Gusztáv nyomdája, 48. p.

55. Goerre M. (2001): Molecular identification of fruit genetic resources and integration of molecular information into a common European database useful for genebank curators and nurserymen. 72-73. p. In: Maggioni L., Fischer M., Lateur M., Lamont E.J., Lipman E. (szerk.). 2004. Report of a working group on Malus/Pyrus. Second meeting, 2-4 May 2002, Dresden-Pillnitz. Germany. International Plant Genetic Resources Institute, Rome, Italy. 97. p.

56. Goulão L., Oliveira C. M. (2001): Molecular characterisation of cultivars of apple (Malus $\times$ domestica Borkh.) using microsatellite (SSR and ISSR) markers. Euphytica, 122:81-89.

57. Guarino C., Santoro S., De Simone L., Lain O., Cipriani G., Testolin R. (2006): Genetic diversity in a collection of ancient cultivars of apple (Malus x domestica Borkh.) as revealed by SSR-based fingerprinting. J Hortic Sci Biotech, 81(1):39-44.

58. Guilford P., Prakash S., Zhu J. M., Rikkerink E., Gardiner S., Bassett H., Foster R. (1997): Microsatellites in Malus x domestica (apple): abundance, polymorphism and cultivar identification. Theor Appl Genet, 94:249-254.

59. G. Tóth M. (2001): Gyümölcsészet 2. kiadás Nyíregyháza: Primon Kiadó, 489. p.

60. G. Tóth M. (2005a): A Kárpát-medence régi almafajtáinak felderítése és megmentése. Kertgazdaság, 37(2):24-29.

61. G. Tóth M. (2005b): Régi magyar almafajták mint a rezisztencianemesítés génforrásai és a környezettudatos külterjes gyümölcsök elemei. Kertgazdaság különszám. A fajtaválaszték fejlesztése a kertészetben, 23-31. p.

62. Hajósné Novák M. (szerk.) (1999): Genetikai variabilitás a növénynemesítésben. Budapest: Mezőgazda Kiadó. 142. p.

63. Halász J., Hegedűs A., György Zs., Pállinger É., Tóth M. (2011): S-genotyping of old apple cultivars from the Carpathian basin: methodological, breeding and evolutionary aspects. Tree Genet Genomes, 7:1135-1145.

64. Hammer R., Harper D. A. T., Ryan P. D. (2001): PAST: Paleontological statistics software package for education and data analysis. Palaeontol Electron, 4(1):9. http://palaeo-electronica.org/2001_1/past/issue1_01.htm

65. Harris S. A., Robinson J. P., Juniper B. E. (2002): Genetic clues to the origin of the apple. Trends Genet, 18:426-430.

66. Hemmat M., Weeden N. F., Connor P. J., Brown S. K. (1997): A DNA marker for columnar growth habit in apple contains a simple sequence repeat. J Amer Soc Hort Sci, 122: 347-349.

67. Herszényi L. (1934): Gyümölcsfajta ismertetés. Budapest: Stephaneum nyomda Rt., 269. p.

68. Hinterthür, L. (ca. 1890): Der Apfel. Praktisches Handbuch über Anbau, Zucht, Pflege, Arten, Verwertung, Schädlinge etc. des Apfel-Obstes. Leipzig: Amthor'sche Verlagsbuchhandlung. 103. p.

69. Hogg R. (1851): British pomology. History, description, classification, and synonymes, of the fruits and fruit trees of Great Britain. The apple. London: Groombridge and Sons. 306. p.

70. Hokanson S. C., Szewc-Mc Fadden A. K., Lamboy W. F., Mc Ferson J. R. (1998): Microsatellite (SSR) markers reveal genetic identities, genetic diversity and relationships in a Malus x domestica Borkh. core subset collection. Theor Appl Genet, 97:671-683. 
71. Hokanson S. C., Lamboy W. F., Szewc-Mc Fadden A. K., Mc Ferson J. R. (2001): Microsatellite (SSR) variation in a collection of Malus (apple) species and hybrids. Euphytica, 118:281-294.

72. Holler C. (2007): Régi gyümölcsfajták és hagyományos gyümölcsök: A táj, a természet, és az ember kincsei. Kertgazdaság, 39(3):76-80.

73. Holler C., Kajtna B., Baric S., Storti A. (2012): Zigeunerapfel oder Roter von Simonffi? Pomologische und molekularbiologische Verifizierung der selben Sorte. Besseres Obst, 57(5):20-22.

74. Horn J. (1937): Alma I. 7-34. p. In: Kerekes L. (szerk.). 1937. Pomológia. Harmadik kötet. Alma I. Növényvédelem és Kertészet Kiadása. 34. p.

75. Hu J., Wang L., Li J. (2011): Comparison of genomic SSR and EST-SSR markers for estimating genetic diversity in cucumber. Biol Plantarum. 55(3): 577-580.

76. Ifjú Z. (1980): A virágzás és befolyásoló tényezői. 43-46. p. In: Nyéki J. (szerk.) Gyümölcsfajták virágzásbiológiája és termékenyülése. Budapest: Mezőgazdasági Kiadó, 334. p.

77. Jaccard P. (1908): Nouvelles recherches sur la distribution florale. Bulletin de la Socit vaudoise des sciences naturelles, 44: 223-270.

78. James C. M., Clarke J. B., Evans K. M. (2004): Identification of molecular markers linked to the mildew resistance gene $\mathrm{Pl}-\mathrm{d}$ in apple. Theor Appl Genet, 110:175-181.

79. Janick J., Cummins J. N., Brown S. K., Hemmat M. (1996): Apples. 1-77. p. In: Janick J., Moore J. N. (szerk.): Fruit breeding. Tree and tropical fruits, vol 1. New York: John Wiley and Sons, 616. p.

80. Jung S., Staton M., Lee T., Blenda A., Svancara R, Abbott A., Main D. (2008): GDR (Genome Database for Rosaceae): integrated web-database for Rosaceae genomics and genetics data. Nucleic Acids Res, 36 (Database issue): D1034-40. Epub 2007 Oct 11. http://www.ncbi.nlm.nih.gov/pubmed/17932055

81. Juniper B., Watkins R., Harris S. (1996): The origin of the apple. Acta Hortic, 484:2733.

82. Kellerhals M., Dolega E., Gessler C., Koller B., Lespinasse Y., Parisi L. et al. (1999): EU-Projekt: Dauerhafte Apfel-Resistenz in Europa (DARE). Schweizerische Zeitschrift für Obst- und Weinbau, 17: 421-424.

83. Kellerhals M., Szalatnay D., Hunziker K., Duffy B., Nybom H., Ahmadi-Afzadi M., Höfer M., Richter K., Lateur M. (2012): European pome fruit genetic resources evaluated for disease resistance. Trees, 26:179-189.

84. Kelsey D. F., Brown S. K. (1992): 'McIntosh Wijcik': a columnar mutation of 'McIntosh' apple proving useful in phisiology and breeding research. Fruit Varieties J, 46:83-87.

85. Kenis K., Pauwels E., Van Houtvinck N., Keulemans J. (2001): The use of microsatellites to estabilish unique fingerprints for apple cultivars and some of their descentants. Acta Hortic, 546:427-431.

86. Kenis K., Keulemans J. (2005): Genetic linkage maps of two apple cultivars (Malus x domestica Borkh.) based on AFLP and microsatellite markers. Mol Breeding, 15:205-219.

87. Kenis K., Keulemans J., Davey M. (2008): Identification and stability of QTLs for fruit quality traits in apple. Tree Genet Genomes, 4:647-661.

88. Kerekes L. (szerk.). 1937. Pomológia. Harmadik kötet. Alma I. Növényvédelem és Kertészet Kiadása. 34. p.

89. Khan M. A., Durel C.-E., Duffy B., Drouet D., Kellerhals M., Gessler C., Patocchi A. (2007): Development of molecular markers linked to the 'Fiesta' linkage group 7 major QTL for fire blight resistance and their application for marker-assisted selection. Genome, 50:568-577. 
90. Khan M. A., Zhao Y. F., Korban S. S. (2012): Molecular mechanisms of pathogenesis and resistance to the bacterial pathogen Erwinia amylovora, causal agent of fire blight disease in Rosaceae. Plant Mol Biol Rep, 30(2):247-260.

91. Khoufi S., Khamassi K., Teixeira da Silva J. A., Chaabane R., Naceur M. B. B. (2012): Morphological and molecular characterization of six of the most frequently cultivated hard wheat varieties in Tunisia. J Plant Breeding Crop Sci, 4(7):106-114.

92. King G. J., Brown L., Ryder C., Periam N. (1998): Microsatellite markers for accession identification, pedigree analysis and assessment of allelic diversity in Malus genetic resources. 104-113. p. In: Maggioni, L., R. Janes, A. Hayes, T. Swinburne, E. Lipman (szerk): Report of a Working Group on Malus/Pyrus. First meeting, 15-17 May 1997, Dublin, Ireland. International Plant Genetic Resources Institute, Rome, Italy. 130. p.

93. King G. J., Maliepaard C., Lynn J. R., Alston F. H., Durel C.-E., Evans K. M., Griffon B., Laurens F., Manganaris A. G., Schrevens E., Tartarini S., Verhaegh J. (2000): Quantitative genetic analysis and comparison of physical and sensory descriptors relating to fruit flesh firmness in apple (Malus pumila Mill.). Theor Appl Genet, 100:1074-1084.

94. Király I., Pedryc A., Halász J., Deák T., Tóth M. (2009): Parent identification of Hungarian apple cultivars using SSR markers. Acta Hortic, 839:471-477.

95. Kitahara K., Matsumoto S., Yamamoto T., Soejima J., Kimura T., Komatsu H., Abe K. (2005): Parent identification of eight apple cultivars by $S$-RNase analysis and Simple Sequence Repeat markers. HortScience, 40(2):314-317.

96. Komonyi É. (2010): Kárpátalja tájalmafajtáinak pomológiai leírása. Acta Beregsasiensis, IX(1):245-254.

97. Kovács J. (1861): Kalauz a gyümölcsfaültetéshez és nyeséshez. Pest: Kiadja Heckmann Gusztáv. 76. p.

98. Kumar S., Bink M. C. A. M., Volz R. K., Bus V. G. M., Chagné D. (2012): Towards genomic selection in apple (Malus $\times$ domestica Borkh.) breeding programmes: Prospects, challenges and strategies. Tree Genet Genomes, 8:1-14.

99. Lateur M., Ordidge M., Engels J., Lipman E. (2013): Report of a Working Group on Malus/Pyrus Fourth Meeting, 7-9 March 2012, Weggis, Switzerland. 39. p. http://www.ecpgr.cgiar.org/fileadmin/www.ecpgr.cgiar.org/NW_and_WG_UPLOA DS/MalusPyrus2012/Malus_Pyrus_4_Weggis_draft_for_Web_31_January_2013_n ewURL.pdf

100. Laurens F., Durel C. E., Lascostes M. (2004): Molecular characterization of French local apple cultivars using SSRs. Acta Hortic, 663:639-642.

101. Laurens F., Feugey L. (2010): France: Molecular characterization (SSRs) of some European cultivars. 24. p. In: Lateur M, Maggioni L, Lipman E.: Report of a Working Group on Malus/Pyrus. Third Meeting, 25-27 October 2006, Tbilisi, Georgia. Bioversity International, Rome, Italy. 44. p.

102. Lespinasse Y., Durel C.E., Parisi L., Laurens F., Chevalier M., Pinet C. (2000): A European project: D.A.R.E. - Durable apple resistance in Europe. Acta Hortic, 538:197-200.

103. Liebhard R., Gianfranceschi L., Koller B., Ryder C. D., Tarchini R., van de Weg E., Gessler C. (2002): Development and characterisation of 140 microsatellites in apple (Malus x domestica Borkh.). Mol Breeding, 10:217-241.

104. Liebhard R., Kellerhals M., Pfammatter W., Jertmini M., Gessler C. (2003a): Mapping quantitative physiological traits in apple (Malus x domestica Borkh.). Plant Mol Biol, 52:511-526.

105. Liebhard R., Koller B., Gianfranceschi L., Gessler C. (2003b): Creating a saturated reference map for the apple (Malus $\times$ domestica Borkh.) genome. Theor Appl Genet, 106(8):1497-1508. 
106. Lucas E. (1875a): Rother Stettiner; Brauner Matapfel. 555-556. p.; 367-368. p. In: Lucas E., Oberdieck J. G. C. (szerk.). Illustriertes Handbuch der Obstkunde. I. Band. Apfel. Stuttgart: Verlag von Eugen Urlag. 572. p.

107. Lucas E. (1875b): Systeme, auf die bei jeder Beschreibung der Apfelsorten hingeweisen ist. 21-32. p. In: Lucas E., Oberdieck J. G. C. (szerk.): Illustriertes Handbuch der Obstkunde. I. Band. Apfel. Stuttgart: Verlag von Eugen Urlag. 572. p.

108. Lucas E., Oberdieck J. G. C. (szerk.) (1875): Illustriertes Handbuch der Obstkunde. I. Band. Apfel. Stuttgart: Verlag von Eugen Urlag. 572. p.

109. Maggioni L., Fischer M., Lateur M., Lamont E.J., Lipman E. (szerk.) (2004): Report of a working group on Malus/Pyrus. Second meeting, 2-4 May 2002, Dresden-Pillnitz. Germany. International Plant Genetic Resources Institute, Rome, Italy. 97. p.

110. Magyar Alma Mikroszatellit Adatbázis. http://mkk.szie.hu/dep/genetika/Alma mikroszatellit/Uj/Fooldal.html

111. Mantel N., Valand R. S. (1970): A technique of nonparametric multivariate analysis. Biometrics, 26:547-558.

112. Molnár I. (1898a): Gyümölcstermelés és értékesítés. Budapest: Pátria Irodalmi Vállalat és Nyomdai Rt., 223. p.

113. Molnár I. (1898b): Magyar pomologia. Budapest: Athenaeum Nyomda.

114. Morgan J., Richards A. (1993): The book of apples. London: Ebury Press, 288. p.

115. Morgante M., Olivieri A.M. (1993): PCR-amplified microsatellites as markers in plant genetics. Plant $J, 3: 175-182$.

116. Moriya S., Iwanami H., Kotoda N., Takahashi S., Yamamoto T., Abe K. (2009): Development of a marker-assisted selection system for columnar growth habit in apple breeding. J Jpn Soc Hortic Sci, 78:279-287.

117. Moriya S., Iwanami H., Okada K., Yamamoto T., Abe K. (2011): A practical method for apple cultivar identification and parent-offspring analysis using simple sequence repeat markers. Euphytica, 177:135-150.

118. Muzher B. M., Younis R. A. A., El-Halabi O., Ismail O. M. (2007): Genetic identification of some Syrian local apple (Malus sp.) cultivars using molecular markers. Res J Agric Biol Sci, 3(6):704-713.

119. Nagyistván O. (2012): Történelmi almafajták ploiditás vizsgálata. TDK dolgozat. Budapest.

120. Nagy-Tóth F. (1998): Régi erdélyi almák. Kolozsvár: Erdélyi Múzeum-Egyesület, 352. p.

121. Nei M. (1973): Analysis of gene diversity in subdivided populations. Proc Natl Acad Sci, 70:3321-3323.

122. Nybom H., Garkava-Gustavsson L. (2009): Apple gene banks - for breeding, research or public entertainment? Acta Hortic, 814:71-76.

123. Nybom H., Mikicinski A., Garkava-Gustavsson L., Sehic J., Lewandowski M., Sobiczewski P. (2012): Assessment of fire blight tolerance in apple based on plant inoculations with Erwinia amylovora and DNA markers. Trees, 26:199-213

124. Nyéki J. (1989): Csonthéjas gyümölcsüek virágzása és termékenyülése. Doktori értekezés. MTA, Budapest.

125. Oberdieck J. G. C., Lucas E. (szerk.) (1860): Monatsschrift für Pomologie und praktischen Obstbau. Band VI. Stuttgart: Ebner \& Seubert, 378. p.

126. Ogjanov V., Vujanic-Varga D., Gasic K. (1999): Breeding columnar apples in Novi Sad. Acta Hortic, 484:207-209.

127. Oraguzie N. C., Iwanami H., Soejima J., Harada T., Hall A. (2004): Inheritance of the Md-ACS1 gene and its relationship to fruit softening in apple (Malus $\times$ domestica Borkh.). Theor Appl Genet, 108:1526-1533.

128. Paetkau D., Calvert W., Stirling I., Strobeck C. (1995): Microsatellite analysis of population structure in Canadian polar bears. Mol Ecol, 4:347-354. 
129. Papp D., Ficzek G., Stégerné Máté M., Nótin B., Király I., Tóth M. (2011): Kárpátmedencei régi almafajták beltartalmi értékei és perspektívái a XXI. század hazai gyümölcsnemesítésében. Kertgazdaság, 43(1):23-27.

130. Papp D., Király I., Tóth M. (2012): Régi magyar almafajták előnyben! Biokultúra, XXIII(1):15-17.

131. Patthy L. (1999): 3. Mutation. In: Protein evolution. Oxford: Blackwell Science Ltd., 228. p.

132. Patocchi A., Bigler B., Koller B., Kellerhals M., Gessler C. (2004): Vr2: a new apple scab resistance gene. Theor Appl Genet, 109(5):1087-1092.

133. Patocchi A., Walser M., Tartarini S., Broggini G. A. L., Gennari F., Sansavini S., Gessler C. (2005): Identification by genome scanning approach (GSA) of a microsatellite tightly associated with the apple scab resistance gene Vm. Genome, 48:630-636.

134. Patocchi A., Fernández-Fernández F., Evans K., Silfverberg-Dilworth E., Matasci C. L., Gobbin D., Rezzonico F., Boudichevskaia A., Dunemann F., Stankiewicz-Kosyl M., Mathis F., Durel C. E., Soglio V., Gianfranceschi L., Costa F., Toller C., Cova V., Mott D., Komjanc M., Barbaro E., Voorrips R. E., Rikkerink E., Yamamoto T., Cevik V., Gessler C., van de Weg W. E. (2009a): Development of a set of apple ssrs markers spanning the apple genome, genotyping of HiDRAS plant material and validation of genotypic data. Acta Hortic, 814:603-608.

135. Patocchi A., Frei A., Frey J. E., Kellerhals M. (2009b): Towards improvement of marker assisted selection of apple scab resistant cultivars: Venturia inaequalis virulence surveys and standardization of molecular marker alleles associated with resistance genes. Mol Breeding, 24:337-347.

136. Patzak et al. (2009): Evaluation of old and local apple (Malus $\times$ domesticaBorkh.) varieties from genetic resources by molecular genetic SSR analysis. Agriculture, 55(1): 55-57.

137. Patzak J., Paprštein F., Henychová A. (2011): Identification of apple scab and powdery mildew resistance genes in Czech apple (Malus $\times$ domestica) genetic resources by PCR molecular markers. Czech J Genet Plant, 47(4):156-165.

138. Patzak J., Paprštein F., Henychová A., Sedlák J. (2012): Genetic diversity of Czech apple cultivars inferred from microsatellite markers analysis. Hortic Sci (Prague), 39(4):149-157.

139. Peil A., Garcia-Libreros T., Ritcher K., Trognitz F. C., Trognitz B., Hanke M. V., Flachovsky H. (2007): Strong evidence for fire blight resistance gene of Malus robusta located on linkage group 3. Plant Breeding, 126:470-475.

140. Pereira-Lorenzo S., Ramos-Cabrer A. M., Ascasibar-Errasti J., Piñeiro-Andión J. (2003): Analysis of apple germplasm in Northwestern Spain. J Am Soc Hortic Sci, 128(1):67-84.

141. Pereira-Lorenzo S., Ramos-Cabrer A. M., Díaz-Hernández M. B. (2007): Evaluation of genetic identity and variation of local apple cultivars (Malus $\times$ domestica Borkh.) from Spain using microsatellite markers. Genet Resour Crop Ev, 54:405-420.

142. Pereira-Lorenzo S., Ramos-Cabrer A. M., González-Díaz A. J., Díaz-Hernández M. B. (2008): Genetic assessment of local apple cultivars from La Palma, Spain, using simple sequence repeats (SSRs). Sci Hortic-Amsterdam, 117:160-166.

143. Pessl Instruments (2009): Fieldclimate. URL: http://www.fieldclimate.com/

144. Potts S. M., Han Y., Khan M. A., Kushad M. M., Rayburn A. L., Korban S. S. (2012): Genetic diversity and characterization of a core collection of Malus germplasm using Simple Sequence Repeats (SSRs). Plant Mol Biol Rep, 30(4):827-837.

145. R Development Core Team (2008): R: A language and environment for statistical computing. R Foundation for Statistical Computing, Vienna, Austria. ISBN 3900051-07-0, URL http://www.R-project.org. 
146. Racskó J., Szabó T., Soltész M., Szabó Z., Nyéki J. (2005): Régi magyar alma tájfajták gyümölcsmorfológiai és beltartalmi sajátosságai. Kertgazdaság, 37(3):23-35.

147. Rapaics R. (1937): Bevezetés. 3-6. p. In: Kerekes L. (szerk.). 1937. Pomológia. Harmadik kötet. Alma I. Növényvédelem és Kertészet Kiadása. 34. p.

148. Reim S., Flachowsky H., Hanke M.-V., Peil A. (2008): Verifying the parents of the Pillnitzer apple cultivars. Acta Hortic, 814:319-324.

149. Rodics K. (2008): Biológiai sokféleség és hagyomány. Kertgazdaság, 40(1):3-5.

150. Rosenberg M. S., Anderson C. D. (2011): PASSaGE: Pattern Analysis, Spatial Statistics and Geographic Exegesis. Version 2. Methods Ecol Evol, 2(3):229-232.

151. Routson K. J., Reilley A. A., Henk A. D., Volk G. M. (2009): Identification of historic apple trees in the Southwestern United States and implications for conservation. HortScience, 44(3):589-594.

152. Royo J. B., Itoiz R. (2004): Evaluation of the discriminance capacity of RAPD, isoenzymes and morphologic markers in apple (Malus x domestica Borkh.) and the congruence among classifications. Genet Resour Crop Ev, 51:153-160.

153. Santesteban L. G., Miranda C., Royo J. B. (2009): Assessment of the genetic and phenotypic diversity maintained in apple core collections constructed by using either agro-morphologic or molecular marker data. Span J Agric Res, 7(3):572-584.

154. Sehic J., Garkava-Gustavsson L., Nybom H. (2013): More harmonization needed for DNA-based identification of fruit tree germplasm. Acta Hortic, 976:277-283.

155. Sikorskaite S., Gelvonauskiene D., Stanys V., Baniulis D. (2012): Characterization of microsatellite loci in apple (Malus $\times$ domestica Borkh.) cultivars. Žemdirbyste $=$ Agriculture, 99(2):131-138.

156. Silfverberg-Dilworth E., Matasci C. L., van de Weg W. E., van Kaauwen M. P. W., Walser M., Kodde L. P., Soglio V., Gianfranceschi L., Durel C. E., Costa F., Yamamoto T., Koller B., Gessler C., Patocchi A. (2006): Microsatellite markers spanning the apple (Malus x domestica Borkh.) genome. Tree Genet Genomes, 2:202-224.

157. Soltész M. (1980): Az alma. 111-167. p. In: Nyéki J. (szerk.): Gyümölcsfajták virágzásbiológiája és termékenyülése. Budapest: Mezőgazdasági Kiadó, 334. p.

158. Soltész M. (1982): Almaültetvények fajtatársítása. Kandidátusi értekezés.

159. Soltész M. (1992): Virágzásfenológiai adatok és összefüggések felhasználása az almaültetvények fajtatársításánál. Doktori (MTA) értekezés, Budapest.

160. Soltész M. (1996): Flowering. 80-131. p. In: Nyéki J., Soltész M. (szerk.): Floral biology of temperature zone fruit trees and small fruits. Budapest: Akadémiai Kiadó, 621. p.

161. Soltész M. (2002): Alma. 72-150. p. In: Nyéki J., Soltész M., Szabó Z. (szerk.): Fajtatársítás a gyümölcsültetvényekben. Budapest: Mezőgazda Kiadó, 382. p.

162. Song Y., Zhai H., Yao Y-X., Li M., Du Y-P. (2006): Analysis of genetic diversity of processing apple varieties. Agr Sci China, 5(10):745-750.

163. Stoeckli S., Mody K., Gessler C., Patocchi A., Jermini M., Dorn S. (2008): QTL analysis for aphid resistance and growth traits in apple. Tree Genet Genomes, 4(4):833-847.

164. Stoll R. (1888): Oesterreichisch - Ungarische Pomologie. Klosterneuburg bei Wien.

165. Storti A., Dalla Via J., Baric S. (2012): Comparative molecular genetic analysis of apple genotypes maintained in germplasm collections. Erwerbs-Obstbau, 54:137141.

166. Sun H. H., Zhao Y. B., Li C. M., Chen D. M., Wang Y., Zhang X. Z., Han Z. H. (2012): Identification of markers linked to major gene loci involved in determination of fruit shape index of apples (Malus $\times$ domestica). Euphytica, 185(2):185-193.

167. Surányi D. 2002. Gyümölcsöző sokféleség: Biodiverzitás a gyümölcstermesztésben. Cegléd: Akcident Nyomdaipari Kft. 140. p. 
168. Szalatnay D. (2005): Agronomische und pomologische Beschreibung von ObstGenressourcen. Zwischenbericht. http://www.cpc-skek.ch/fileadmin/pdf/NAPPhaseII/NAP_02-22_JB05.pdf

169. Szalatnay D. (2006): Obst-Descriptoren NAP. 1. http://www.cpcskek.ch/fileadmin/pdf/NAP_Beschreibungshandbuecher/deskriptorenhandbuch_nap.pdf

170. Szalatnay D., Eder-Bauermeister R., Duffy B., Kellerhals M. (2009): Characterization of fruit genetic resources in Switzerland. Acta Hortic, 814:143-148.

171. Szalatnay D., Hunziker K. (2011): Beschreibung von Obstgenressourcen BEVOG (NAP 03-21). Schlussbericht.

172. http://www.fructus.ch/downloads/schlussbericht_bevog.pdf

173. Szalay L., Király I., Battey, N. H., Tóth M. (2012): Magyar történelmi almafajták ventúriás varasodásra való fogékonyságának összehasonlító értékelése két helyszínen. Kertgazdaság, 44(2):35-40.

174. Szani Zs. (2007): Alma tájfajták táji tagozódása Magyarországon. Kertgazdaság, 39(2):21-26.

175. Szani Zs. (2011): Történelmi alma- és körtefajták a Kárpát-medencében a népi fajtaismeret és -használat tükrében. PhD értekezés. Budapest

176. Szász G., Tőkei L. (szerk.) (1997): Meteorológia mezőgazdászoknak, kertészeknek, erdészeknek. Budapest: Mezőgazda Kiadó. 722. p.

177. Tartarini S., Gennari F., Pratesi D., Palazzetti C., Sansavini S., Parisi L., Fouillet A., Fouillet V., Durel C. E. (2004): Characterisation and genetic mapping of a major scab resistance gene from the old Italian apple cultivar 'Durello di Forli'. Acta Hortic, 663:129-133.

178. Thomas J. J. (1903): The American Fruit Culturist. New York: William Wood and Company. 823. p.

179. Tignon M., Lateur M., Kettman R., Watillon B. (2001): Distinction between closely related apple cultivars of the Belle-Fleur family using RFLP and AFLP markers. Acta Hortic, 546:509-513.

180. Tomcsányi P. (1998): Fajtaismeret és fajtaértékelés a III. évezred küszöbén. Kertgazdaság, 30(2):77-81.

181. Tommasini L., Batley J., Arnold G. M., Cooke R. J., Donini P., Lee D., Law J. R., Lowe C., Moule C., Trick M., Edwards K. J. (2003): The development of multiplex simple sequence repeat (SSR) markers to complement distinctness, uniformity and stability testing of rape (Brassica napus L.) varieties. Theor Appl Genet, 106:10911101.

182. Tóth M. (2005a). Exploring and preseving old apple cultivars of the Carpathian basin. Int J Hortic Sci, 11(3):9-13.

183. Tóth M. (2005b): Pomology of gene resoureces bearing resistance to Erwinia amylovora. Int J Hortic Sci, 11(3):29-33.

184. Tóth M. (2005c): Régi magyar almafajták mint a rezisztencianemesítés génforrásai és és a környezettudatos külterjes gyümölcsösök elemei. Kertgazdaság Különszám. A fajtaválaszték fejlesztése a a kertészetben. 23-32. p.

185. Tóth M. (2005d): Malus genotípusok pomológiai és genetikai értékelése. Akadémiai doktori értekezés; MTA. Budapest

186. Tóth M. (2013): Az alma fajtarendszertana. In: Tóth M. (szerk.): Magyarország kultúrflórája. 77. kötet. (in press)

187. Tóth M., Rozsnyay Zs., Quang D. X. (1994): Apple Breeding for Disease Resistance in Hungary. p. 27-30. in: Schmidt, H. and Kellerhals (Eds.): Progress in Temperature fruit Breeding. Dordrecht: Kluwer Academic Publishers. 470. p.

188. Tóth M., Szani Zs. (2004): Traditional farming within the Carpathian basin pomaceous fruits. Int J Hortic Sci, 10(3):15-18. 
189. Tóth M., Hevesi M., Honty K., Kása K. (2005a): Kárpátalján fellelhető alma genotípusok (régi és helyi fajták) tüzelhalással szembeni ellenállósága növényházi vizsgálatok alapján. Növényvédelem, 41(8):341-348.

190. Tóth M., Balikó E., Szani Zs. (2005b): Evaluation of fruit quality of old apple cultivars originating from the foot of the Carpathian Mountains, for utilization in breeding and in organic farming, Int J Hortic Sci, 11(3):15-21.

191. Tóth M., Kása K., Szani Zs., Balikó E. (2005c): Traditional old apple cultivars as new gene sources for apple breeding. Acta Hortic, 663(2):609-612.

192. Tóth M., Hudák K., Geiszler J. (2007): Gyümölcsfajta-kutatás az Aggteleki Nemzeti Park területén. XIII. Növénynemesítési Tudományos Napok 2007. március 12. Budapest, Összefoglalók, 179.

193. Tóth M., Ficzek G., Király I., Kovács Sz., Hevesi M., Halász J., Szani Zs. (2012a): 'Artemisz', 'Cordelia', 'Hesztia', and 'Rosmerta': New hungarian multiresistant apple cultivars. HortScience, 47:1795-1800.

194. Tóth M., Ficzek G., Király I., Honty K., Hevesi M. (2013): Evaluation of old Carpathian apple cultivars as genetic resources of resistance to fire blight (Erwinia amylovora). Trees, 27:597-605.

195. UPOV. International Union for the Protection of New Varieties of Plants. (2002): General introduction to the examination of distinctness, uniformity and stability and the development of harmonized descriptions of new varieties of plants. Technical Guideline

TG/1/3. http://www.upov.int/export/sites/upov/publications/en/tg_rom/pdf/tg_1_3.pdf

196. UPOV. International Union for the Protection of New Varieties of Plants. (2003): Working group on biochemical and molecular techniques and dna-profiling in particular. BMT/8/24. Eighth Session Tsukuba, Japan, September 3 to 5, 2003. Protection of plant breeders' rights and use of advanced technology. http://www.upov.int/edocs/mdocs/upov/en/bmt/8/bmt_8_24.pdf

197. UPOV. International Union for the Protection of New Varieties of Plants. (2005): Guidelines for the conduct of tests for distinctness, uniformity and stability. Apple. Technical Guideline TG/14/9. 45 p. http://www.upov.int/edocs/tgdocs/en/tg014.pdf

198. UPOV. International Union for the Protection of New Varieties of Plants. (2010): Working group on biochemical and molecular techniques and DNA profiling in particular. BMT/12/23. Twelfth Session Ottawa, Canada, May 11 to 13, 2010. http://www.upov.int/edocs/mdocs/upov/en/bmt/12/bmt_12_23.pdf

199. UPOV. International Union for the Protection of New Varieties of Plants (2011): Possible use of molecular markers in the examination of distinctness, uniformity and stability (DUS). UPOV/INF/18/1. http://www.upov.int/edocs/infdocs/en/upov_inf_18_1.pdf.

200. Urbanovich O.Y., Kazlovskaya Z.A. (2007): Identification of apple tree cultivars growing in Belarus using SSR-markers. Acta Hortic, 839:479-486.

201. van Treuren R., Kemp H., Ernsting G., Jongejans B., Houtman H., Visser L. (2010): Microsatellite genotyping of apple (Malus $\times$ domestica Borkh.) genetic resources in the Netherlands: application in collection management and variety identification. Genet Resour Crop Ev, 57:853-865.

202. Varshney R. K., Graner A., Sorrells M. E. (2005): Genic microsatellite markers in plants: features and applications. Trends Biotechnol, 23(1):48-55.

203. Velasco R., Zharkikh A., Affourtit J., Dhingra A., Cestaro A., Kalyanaraman A., Fontana P., Bhatnagar S. K., Troggio M. et al. (2010): The genome of the domesticated apple (Malus $\times$ domestica Borkh.). Nat Genet, 42:833-839.

204. Velich I. (2001): A mutáció. 354-364. p. In: Velich I. (szerk.): Növénygenetika. Budapest: Mezőgazda Kiadó, 549. p. 
205. Venturi S., Dondini L., Donini P., Sansavini S. (2006): Retrotransposon characterisation and fingerprinting of apple clones by S-SAP markers. Theor Appl Genet, 112:440-444.

206. Vercier J. (1948): La détermination rapide des variétés de fruits [1], Poires, pommes: méthode chiffrée, inédite. Párizs: Librairie J.-B. Baillère et fils. 330. p.

207. Vinatzer B. A., Patocchi A., Tartarini S., Gianfraneschi L., Sansavini S., Gessler C. (2004): Isolation of two microsatellite markers from BAC clones of the $V f$ scab resistance region and molecular characterization of scab-resistant accessions in Malus germplasm. Plant Breeding, 123(4):321-326.

208. Wagner H. W., Sefc K. M. (1999): IDENTITY 1.0. Freeware program for the analysis of microsatellite data. Centre for Applied Genetics, University of Agricultural Sciences Vienna. http://www-ang.kfunigraz.ac.at/ sefck

209. Wang J., Tian L., Madlung A., Lee H. S., Chen M., Lee J. J., Watson B., Kagochi T., Comai L., Chen Z. J. (2004): Stochastic and epigenetic changes of gene expression in Arabidopsis polyploids. Genetics, 167:1961-1973.

210. Warder J. A. (1867): American Pomology. Apples. New York: Orange Judd and Company. 744. p.

211. Weber J.L., May P.E. (1989): Abundant class of human DNA polymorphism which can be typed using the polymerase chain reaction. Am J Hum Genet, 44: 388-396.

212. Wichmann B., Galli Zs., Molnár S., Galbács Zs., Kiss E., Szabó T., Heszky L. (2007): Molecular identification of old Hungarian apple varieties. Int J Hortic Sci, 13(3):3742.

213. Wichmann B., Galli Zs., Szabó T., Kovács L., Heszky L., Kiss E. (2010): Alma kereskedelmi és tájfajták elkülönítése európai standard SSR markerekkel. Kertgazdaság, 42(1):68-75.

214. Wünsch A., Hormaza J. I. (2002): Cultivar identification and genetic fingerprinting of temperate fruit tree species using DNA markers. Euphytica, 125:59-67.

215. Xuan H., Mayr U., Büchele M. (2010): Fingerprinting practices applied to the KOB heritage apple cultivars using SSRs as proposed by the ECPGR_FN. Acta Hortic, 859:183-190.

216. Yao Y., Zhai H., Zhao L., Yi K., Liu Z., Song Y. (2008): Analysis of the apple fruit acid/low-acid trait by SSR markers. Front Agric China, 2(4):463-466.

217. Yao L., Zheng X., Cai D., Gao Y., Wang K., Cao Y., Teng Y. (2010): Exploitation of Malus EST-SSRs and the utility in evaluation of genetic diversity in Malus and Pyrus. Genet Resour Crop Ev, 57:841-851.

218. Zhang Q., Li J., Zhao Y., Korban S. S., Han Y. (2012): Evaluation of genetic diversity in chinese wild apple species along with apple cultivars using SSR markers. Plant Mol Biol Rep, 30(3):539-546.

219. Zhao G., Dai H., Chang L., Ma Y., Sun H., He P., Zhang Z. (2010): Isolation of two novel complete Ty1-copia retrotransposons from apple and demonstration of use of derived S-SAP markers for distinguishing bud sports of Malus $\times$ domestica cv. 'Fuji'. Tree Genet Genomes, 6(1):149-159.

220. www.hidras.unimi.it 
221. 2. melléklet. Az UPOV (2005) által a TG/14/9 számú irányelvben az almafajták jellemzéséhez javasolt tulajdonságok, azok kifejeződési fokozatai és kódszámai

\begin{tabular}{|c|c|c|c|}
\hline Sorszám & Tulajdonság & Kifejeződési fokozat & Kód \\
\hline \multirow[t]{4}{*}{1.} & Fa: növekedési erély & nagyon gyenge & 1 \\
\hline & & gyenge & 3 \\
\hline & & közepes & 5 \\
\hline & & erös & 7 \\
\hline \multirow[t]{2}{*}{2.} & Fa: típus & oszlopos & 1 \\
\hline & & elágazó & 2 \\
\hline \multirow[t]{4}{*}{3.} & Csak elágazó típusú fajták: & feltörő & 1 \\
\hline & Fa: habitus & elterülő & 2 \\
\hline & & lehajló & 3 \\
\hline & & csüngő & 4 \\
\hline \multirow[t]{3}{*}{4.} & Fa: terméshozás típusa & csak termőnyársakon & 1 \\
\hline & & termőnyársakon és hosszú vesszőkön & 2 \\
\hline & & csak hosszú vesszőkön & 3 \\
\hline \multirow[t]{4}{*}{5.} & Vesszö: vastagság & vékony & 3 \\
\hline & & közepes & 5 \\
\hline & & vastag & 7 \\
\hline & & nagyon vastag & 9 \\
\hline \multirow[t]{4}{*}{6.} & Vessző: ízköz hosszúsága & nagyon rövid & 1 \\
\hline & & rövid & 3 \\
\hline & & közepes & 5 \\
\hline & & hosszú & 7 \\
\hline \multirow[t]{5}{*}{7.} & Vessző: színe a napos oldalon & zöldesbarna & 1 \\
\hline & & pirosasbarna & 2 \\
\hline & & világosbarna & 3 \\
\hline & & középbarna & 4 \\
\hline & & sötétbarna & 5 \\
\hline \multirow[t]{5}{*}{8.} & Vessző: szőrözöttség (a vessző felső felén) & nincs vagy nagyon gyenge & 1 \\
\hline & & gyenge & 3 \\
\hline & & közepes & 5 \\
\hline & & erös & 7 \\
\hline & & nagyon erös & 9 \\
\hline \multirow[t]{3}{*}{9.} & Vessző: paraszemölcsök száma & kevés & 3 \\
\hline & & közepes & 5 \\
\hline & & sok & 7 \\
\hline \multirow[t]{3}{*}{10.} & Levéllemez: hajtáshoz viszonyított állása & felálló & 1 \\
\hline & & kiálló & 2 \\
\hline & & csüngő & 3 \\
\hline \multirow[t]{4}{*}{11.} & Levéllemez: hosszúság & nagyon rövid & 1 \\
\hline & & rövid & 3 \\
\hline & & közepes & 5 \\
\hline & & hosszú & 7 \\
\hline \multirow[t]{3}{*}{12.} & Levéllemez: szélesség & keskeny & 3 \\
\hline & & közepes & 5 \\
\hline & & széles & 7 \\
\hline \multirow[t]{3}{*}{13.} & Levéllemez: hosszúság/szélesség aránya & kicsi & 3 \\
\hline & & közepes & 5 \\
\hline & & nagy & 7 \\
\hline \multirow[t]{3}{*}{14.} & Levéllemez: zöld szín intenzitása & világos & 3 \\
\hline & & közepes & 5 \\
\hline & & sötét & 7 \\
\hline \multirow[t]{5}{*}{15.} & Levéllemez: szélének bemetszése (felső fele) & csipkés & 1 \\
\hline & & kétszeresen csipkés & 2 \\
\hline & & fürészes 1. típusú & 3 \\
\hline & & fürészes 2. típusú & 4 \\
\hline & & kétszeresen fürészes & 5 \\
\hline
\end{tabular}


2. melléklet (folyt.)

\begin{tabular}{|c|c|c|c|}
\hline Sorszám & Tulajdonság & Kifejeződési fokozat & Kód \\
\hline \multirow[t]{3}{*}{16.} & Levéllemez: szőrözöttség a fonákán & nincs vagy nagyon gyenge & 1 \\
\hline & & közepes & 2 \\
\hline & & erös & 3 \\
\hline \multirow[t]{3}{*}{17.} & Levélnyél: hosszúság & rövid & 3 \\
\hline & & közepes & 5 \\
\hline & & hosszú & 7 \\
\hline \multirow[t]{3}{*}{18.} & Levélnyél: antociános színeződés kiterjedése az & kicsi & 3 \\
\hline & alaptól & közepes & 5 \\
\hline & & nagy & 7 \\
\hline \multirow[t]{7}{*}{19.} & Virág: meghatározó szín szirombimbó & fehér & 1 \\
\hline & állapotban & sárgás rózsaszín & 2 \\
\hline & & világos rózsaszín & 3 \\
\hline & & sötét rózsaszín & 4 \\
\hline & & középpiros & 5 \\
\hline & & sötétpiros & 6 \\
\hline & & bíborszínü & 7 \\
\hline \multirow[t]{4}{*}{20.} & Virág: átmérő vízszintes helyzetbe nyomott & nagyon kicsi & 1 \\
\hline & sziromlevelekkel & kicsi & 3 \\
\hline & & közepes & 5 \\
\hline & & nagy & 7 \\
\hline \multirow[t]{3}{*}{21.} & Virág: sziromlevelek elrendeződése & szabadon álló & 1 \\
\hline & & közbülső & 2 \\
\hline & & átfedő & 3 \\
\hline \multirow[t]{3}{*}{22.} & Virág: bibék helyzete a portokokhoz & alattuk & 1 \\
\hline & viszonyítva & egy szintben & 2 \\
\hline & & felettuik & 3 \\
\hline \multirow[t]{5}{*}{23.} & Kis gyümölcs: antociános fedőszín kiterjedése & nincs vagy nagyon kicsi & 1 \\
\hline & & kicsi & 3 \\
\hline & & közepes & 5 \\
\hline & & nagy & 7 \\
\hline & & nagyon nagy & 9 \\
\hline \multirow[t]{9}{*}{24.} & Gyümölcs: méret & nagyon kicsi & 1 \\
\hline & & nagyon kicsi - kicsi & 2 \\
\hline & & kicsi & 3 \\
\hline & & kicsi - közepes & 4 \\
\hline & & közepes & $\begin{array}{l}5 \\
6\end{array}$ \\
\hline & & közepes - nagy & 7 \\
\hline & & nagy & 8 \\
\hline & & nagy - nagyon nagy & 9 \\
\hline & & nagyon nagy & \\
\hline \multirow[t]{3}{*}{25.} & Gyümölcs: magasság & kicsi & 3 \\
\hline & & közepes & 5 \\
\hline & & nagy & 7 \\
\hline \multirow[t]{3}{*}{26.} & Gyümölcs: átmérő & kicsi & 3 \\
\hline & & közepes & 5 \\
\hline & & nagy & 7 \\
\hline \multirow[t]{5}{*}{27.} & Gyümölcs: magasság/átmérő aránya & nagyon kicsi & 1 \\
\hline & & kicsi & 3 \\
\hline & & közepes & 5 \\
\hline & & nagy & 7 \\
\hline & & nagyon nagy & 9 \\
\hline \multirow[t]{7}{*}{28.} & Gyümölcs: alak & befüződve hengeres & 1 \\
\hline & & kúpos & 2 \\
\hline & & tojás alakú & 3 \\
\hline & & hengeres & 4 \\
\hline & & ellipszoid & 5 \\
\hline & & gömbölyded & 6 \\
\hline & & lapított ellipszoid & 7 \\
\hline
\end{tabular}


2. melléklet (folyt.)

\begin{tabular}{|c|c|c|c|}
\hline Sorszám & Tulajdonság & Kifejeződési fokozat & Kód \\
\hline \multirow[t]{3}{*}{29.} & Gyümölcs: bordázottság & nincs vagy gyenge & 1 \\
\hline & & közepes & 2 \\
\hline & & erős & 3 \\
\hline \multirow[t]{3}{*}{30.} & Gyümölcs: barázdáltság a csészemélyedés & nincs vagy gyenge & 1 \\
\hline & szélén & közepes & 2 \\
\hline & & erős & 3 \\
\hline \multirow[t]{3}{*}{31.} & Gyümölcs: csésze mérete & kicsi & 3 \\
\hline & & közepes & 5 \\
\hline & & nagy & 7 \\
\hline \multirow[t]{3}{*}{32.} & Gyümölcs: csészelevél hosszúsága & rövid & 3 \\
\hline & & közepes & 5 \\
\hline & & hosszú & 7 \\
\hline \multirow[t]{3}{*}{33.} & Gyümölcs: héj hamvassága & nincs vagy gyenge & 1 \\
\hline & & közepes & 2 \\
\hline & & erős & 3 \\
\hline \multirow[t]{3}{*}{34.} & Gyümölcs: héj zsírossága & nincs vagy gyenge & 1 \\
\hline & & közepes & 2 \\
\hline & & erös & 3 \\
\hline \multirow[t]{6}{*}{35.} & Gyümölcs: alapszín & nem látható & 1 \\
\hline & & fehéressárga & 2 \\
\hline & & sárga & 3 \\
\hline & & fehéreszöld & 4 \\
\hline & & sárgászöld & 5 \\
\hline & & zöld & 6 \\
\hline \multirow[t]{5}{*}{36.} & Gyümölcs: fedőszín viszonylagos felülete & nincs vagy nagyon kicsi & 1 \\
\hline & & kicsi & 3 \\
\hline & & közepes & 5 \\
\hline & & nagy & 7 \\
\hline & & nagyon nagy & 9 \\
\hline \multirow[t]{6}{*}{37.} & Gyümölcs: fedőszín árnyalata - hamvasság & nincs & 0 \\
\hline & letörlése után & narancsvörös & 1 \\
\hline & & rózsaszín-piros & 2 \\
\hline & & piros & 3 \\
\hline & & bíborpiros & 4 \\
\hline & & barnáspiros & 5 \\
\hline \multirow[t]{4}{*}{38.} & Gyümölcs: fedőszín intenzitása & nincs & 0 \\
\hline & & világos & 3 \\
\hline & & közepes & 5 \\
\hline & & sötét & 7 \\
\hline \multirow[t]{8}{*}{39.} & Gyümölcs: fedőszín jellege & nincs & 0 \\
\hline & & csak mosott & 1 \\
\hline & & mosott és gyengén csíkozott & 2 \\
\hline & & mosott és erősen csíkozott & 3 \\
\hline & & gyengén mosott és erősen csíkozott & 4 \\
\hline & & csak csíkozott (nem mosott) & 5 \\
\hline & & mosott és márványozott & 6 \\
\hline & & mosott, csíkozott és márványozott & 7 \\
\hline \multirow[t]{4}{*}{40.} & Gyümölcs: csíkok szélessége & nincs & 0 \\
\hline & & keskeny & 3 \\
\hline & & közepes & 5 \\
\hline & & széles & 7 \\
\hline \multirow[t]{3}{*}{41.} & Gyümölcs: parásodás felülete a kocsány körül & nincs vagy kicsi & 1 \\
\hline & & közepes & 2 \\
\hline & & nagy & 3 \\
\hline \multirow[t]{3}{*}{42.} & Gyümölcs: parásodás felülete a gyümölcs & nincs vagy kicsi & 1 \\
\hline & oldalán & közepes & 2 \\
\hline & & nagy & 3 \\
\hline \multirow[t]{3}{*}{43.} & Gyümölcs: parásodás felülete a csészemélyedés & nincs vagy kicsi & 1 \\
\hline & körül & közepes & 2 \\
\hline & & nagy & 3 \\
\hline
\end{tabular}


2. melléklet (folyt.)

\begin{tabular}{|c|c|c|c|}
\hline Sorszám & Tulajdonság & Kifejeződési fokozat & Kód \\
\hline \multirow[t]{3}{*}{44.} & Gyümölcs: paraszemölcsök száma & kevés & 3 \\
\hline & & közepes & 5 \\
\hline & & sok & 7 \\
\hline \multirow[t]{3}{*}{45.} & Gyümölcs: paraszemölcsök mérete & kicsi & 3 \\
\hline & & közepes & 5 \\
\hline & & nagy & 7 \\
\hline \multirow[t]{5}{*}{46.} & Gyümölcs: kocsány hosszúsága & nagyon rövid & 1 \\
\hline & & rövid & 3 \\
\hline & & közepes & 5 \\
\hline & & hosszú & 7 \\
\hline & & nagyon hosszú & 9 \\
\hline \multirow[t]{3}{*}{47.} & Gyümölcs: kocsány vastagsága & vékony & 3 \\
\hline & & közepes & 5 \\
\hline & & vastag & 7 \\
\hline \multirow[t]{3}{*}{48.} & Gyümölcs: kocsánymélyedés mélysége & sekély & 3 \\
\hline & & közepes & 5 \\
\hline & & mély & 7 \\
\hline \multirow[t]{3}{*}{49.} & Gyümölcs: kocsánymélyedés szélessége & keskeny & 3 \\
\hline & & közepes & 5 \\
\hline & & széles & 7 \\
\hline \multirow[t]{3}{*}{50.} & Gyümölcs: csészemélyedés mélysége & sekély & 3 \\
\hline & & közepes & 5 \\
\hline & & mély & 7 \\
\hline \multirow[t]{3}{*}{51.} & Gyümölcs: csészemélyedés szélessége & keskeny & 3 \\
\hline & & közepes & 5 \\
\hline & & széles & 7 \\
\hline \multirow[t]{5}{*}{52.} & Gyümölcs: hús szilárdsága & nagyon puha & 1 \\
\hline & & puha & 3 \\
\hline & & közepes & 5 \\
\hline & & szilárd & 7 \\
\hline & & nagyon szilárd & 9 \\
\hline \multirow[t]{6}{*}{53.} & Gyümölcs: hús színe & fehér & 1 \\
\hline & & krémszínü & 2 \\
\hline & & sárgás & 3 \\
\hline & & zöldes & 4 \\
\hline & & rózsaszínü & 5 \\
\hline & & pirosas & 6 \\
\hline \multirow[t]{3}{*}{54.} & Gyümölcs: magrekeszek nyitottsága & zárt vagy kissé nyitott & 1 \\
\hline & (keresztmetszetben) & mérsékelten nyitott & 2 \\
\hline & & teljesen nyitott & 3 \\
\hline \multirow[t]{5}{*}{55.} & Virágzás kezdetének időpontja & nagyon korai & 1 \\
\hline & & korai & 3 \\
\hline & & közepes & 5 \\
\hline & & kései & 7 \\
\hline & & nagyon kései & 9 \\
\hline \multirow[t]{5}{*}{56.} & Szedési érettség időpontja & nagyon korai & 1 \\
\hline & & korai & 3 \\
\hline & & közepes & 5 \\
\hline & & kései & 7 \\
\hline & & nagyon kései & 9 \\
\hline \multirow[t]{9}{*}{57.} & Fogyasztási érettség időpontja & nagyon korai & 1 \\
\hline & & nagyon korai - korai & 2 \\
\hline & & korai & 3 \\
\hline & & korai - közepes & $\begin{array}{l}4 \\
5\end{array}$ \\
\hline & & közepes & $\begin{array}{l}5 \\
6\end{array}$ \\
\hline & & közepes - kései & 7 \\
\hline & & kései & 8 \\
\hline & & kései - nagyon kései & 9 \\
\hline & & nagyon kései & \\
\hline
\end{tabular}


3. melléklet. A levéllemez szélének bemetszése a levél felső felét figyelembe véve a TG/14/9 irányelvben (UPOV, 2005) (1=csipkés, 2=kétszeresen csipkés, 3=fürészes 1. típusú, 4=fürészes 2. típusú, 5=kétszeresen fürészes)
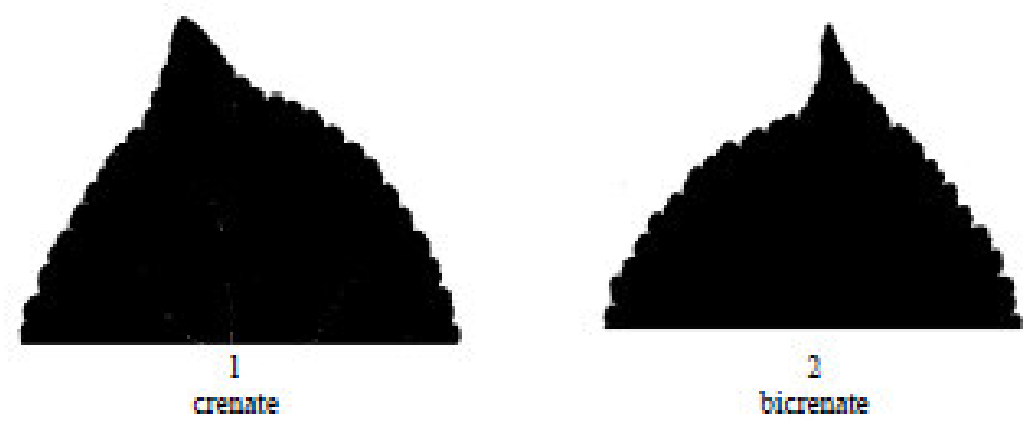

2

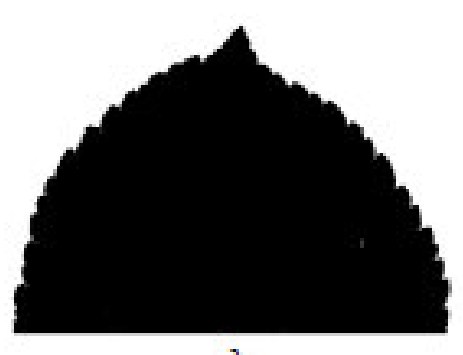

3

serrate type 1
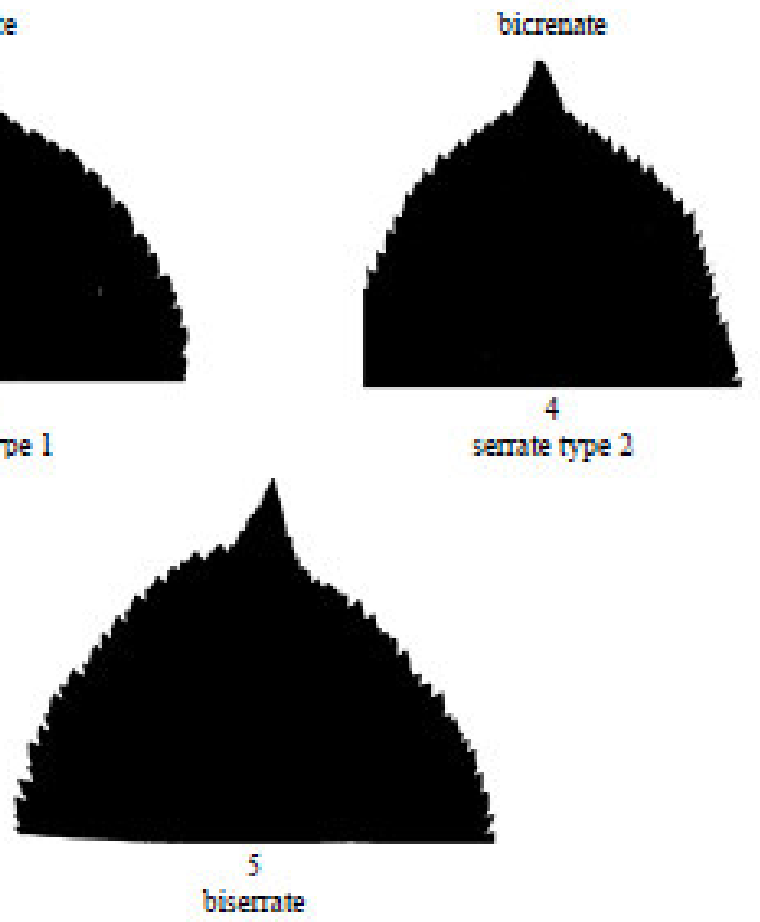
4. melléklet. A gyümölcsalak kifejeződési fokozatai a TG/14/9 irányelvben (UPOV, 2005) (1= befüződve hengeres, 2=kúpos, 3=tojás alakú, 4=hengeres, 5=ellipszoid, 6=gömbölyded, 7=lapított ellipszoid)
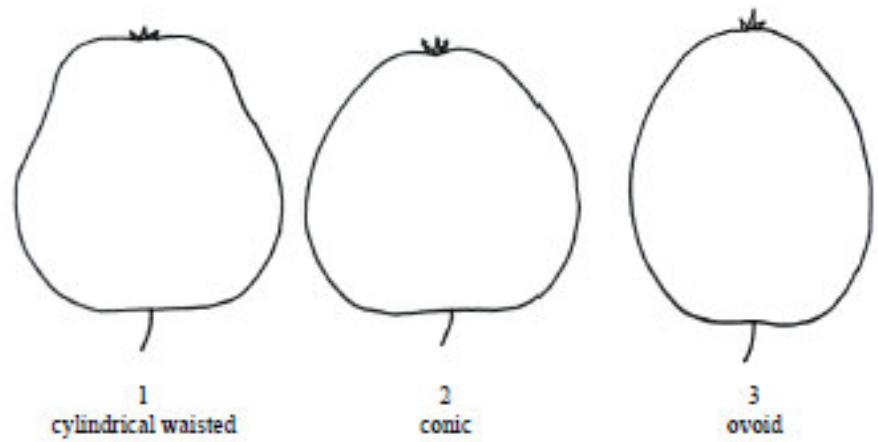

3
ovoid
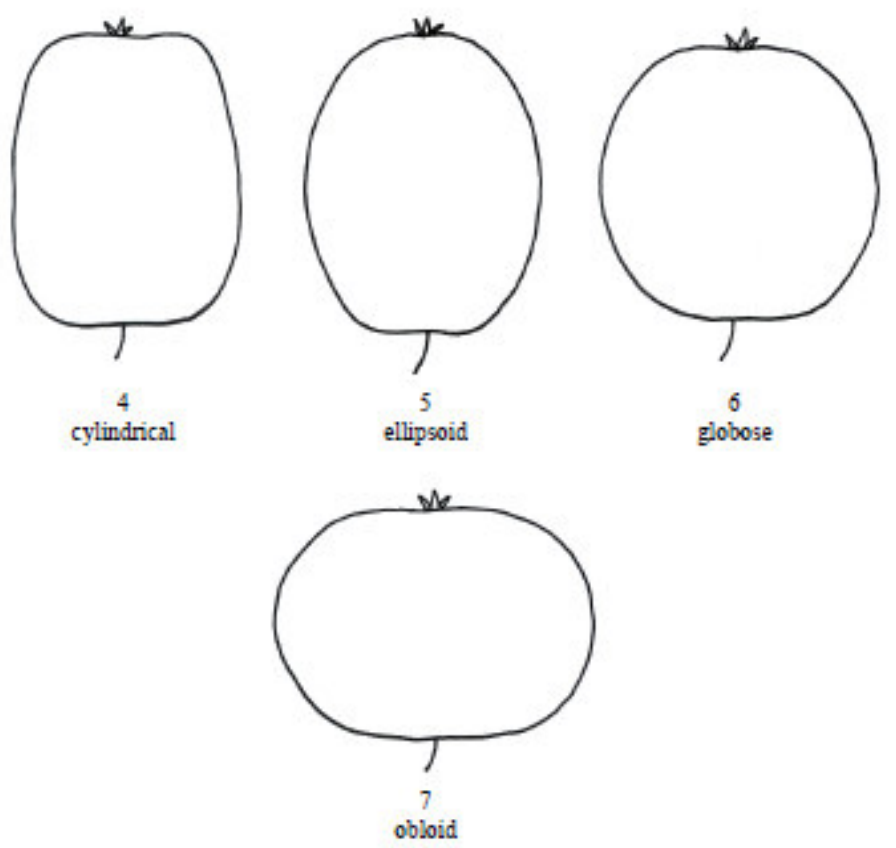
5. melléklet. A vizsgált fajták virágzás kezdetének, fővirágzásának és a virágzás végének napja (Soroksár, 2007-2011)

\begin{tabular}{|c|c|c|c|c|c|c|c|c|c|c|c|c|c|c|c|}
\hline \multirow[b]{2}{*}{ Vizsgált fajta } & \multicolumn{3}{|c|}{2007} & \multicolumn{3}{|c|}{2008} & \multicolumn{3}{|c|}{2009} & \multicolumn{3}{|c|}{2010} & \multicolumn{3}{|c|}{2011} \\
\hline & $\begin{array}{l}\text { Virágzás } \\
\text { kezdete }\end{array}$ & $\begin{array}{c}\text { Fö- } \\
\text { virágzás }\end{array}$ & $\begin{array}{c}\text { Virágzás } \\
\text { vége }\end{array}$ & $\begin{array}{l}\text { Virágzás } \\
\text { kezdete }\end{array}$ & $\begin{array}{c}\text { Fö- } \\
\text { virágzás }\end{array}$ & $\begin{array}{c}\text { Virágzás } \\
\text { vége }\end{array}$ & $\begin{array}{l}\text { Virágzás } \\
\text { kezdete }\end{array}$ & $\begin{array}{c}\text { Fó- } \\
\text { virágzás }\end{array}$ & $\begin{array}{c}\text { Virágzás } \\
\text { vége }\end{array}$ & $\begin{array}{l}\text { Virágzás } \\
\text { kezdete }\end{array}$ & $\begin{array}{c}\text { Fô- } \\
\text { virágzás }\end{array}$ & $\begin{array}{c}\text { Virágzás } \\
\text { vége }\end{array}$ & $\begin{array}{l}\text { Virágzás } \\
\text { kezdete }\end{array}$ & $\begin{array}{c}\text { Fő- } \\
\text { virágzás }\end{array}$ & $\begin{array}{c}\text { Virágzás } \\
\text { vége }\end{array}$ \\
\hline Bánffy Pál & & & & 4. 17. & 4. 21. & 4. 25. & 4.16. & 4. 20. & 4.24. & 4. 21. & 4.23. & 4.30. & 4. 20. & 4.22. & 4.25. \\
\hline Batul 1 & & & & 4. 21 . & 4. 23 . & 4. 28 . & 4. 18 . & 4. 20 . & 4. 24 . & 4. 23 . & 4. 26 . & 5. 3. & 4. 20 . & 4. 22 . & 4. 25 . \\
\hline Batul 2 & 4. 16 . & 4. 20 . & 4. 23 . & 4. 17. & 4. 21 . & 4. 28 . & 4. 16 . & 4. 20 . & 4. 24 . & 4. 23 . & 4. 26 . & 4. 30 . & 4. 20 . & 4. 22 . & 4. 28 . \\
\hline Batul 3 & 4. 12 . & 4. 16 . & 4. 18 . & 4. 21 . & 4. 23 . & 4. 28 . & 4. 20 . & 4. 24 . & 4. 28 . & 4. 23 . & 4. 26 . & 5. 3. & 4. 20 . & 4. 22 . & 4. 28 . \\
\hline Baumann renet & & & & 4. 17 . & 4. 21 . & 4. 28 . & 4. 16 . & 4. 20 . & 4. 24 . & 4. 23 . & 4. 26 . & 5. 3. & 4. 20 . & 4. 22 . & 4. 28 . \\
\hline Beregi sóvári 1 & & & & 4. 17. & 4. 21 . & 4. 30 . & 4. 20 . & 4. 24 . & 4. 28 . & 4. 23 . & 4. 26. & 4. 30 . & 4. 22 . & 4. 24 . & 4. 28 . \\
\hline Beregi sóvári 2 & 4. 12 . & 4. 16. & 4. 27. & 4. 17. & 4. 21 . & 4. 28 . & 4. 16 . & 4. 20 . & 4. 24 . & 4. 23 . & 4. 26 . & 5. 3. & 4. 20 . & 4. 22 . & 4. 28 . \\
\hline Börkormos renet & 4. 16. & 4. 18 . & 4. 23. & 4. 17 . & 4. 21 . & 4. 28 . & 4. 16 . & 4. 20 . & 4. 24 . & 4. 23 . & 4. 26. & 5. 3 . & 4. 22 . & 4. 24 . & 4. 28 . \\
\hline Budai Domokos & & & & & & & 4. 20 . & 4. 24 . & 4. 28 . & & & & 4. 22 . & 4. 24 . & 4. 28 . \\
\hline Budai Ignác & & & & 4. 23 . & 4. 28 . & 5.3. & 4. 24 . & 4. 26 . & 4. 28 . & 4. 26 . & 4. 28 . & 5. 3. & & & \\
\hline Cigány alma & 4. 16. & 4. 18 . & 4. 20 . & 4. 17 . & 4. 21 . & 4. 23 . & 4. 16 . & 4. 20 . & 4. 24 . & 4. 23 . & 4. 26 . & 4. 28 . & 4. 22 . & 4. 24 . & 4. 28 . \\
\hline Cserepánya & & & & 4. 14 . & 4. 21 . & 4. 28 . & 4. 16 . & 4. 20 . & 4. 24 . & 4. 23 . & 4. 26 . & 5.3. & 4. 22 . & 4. 24 . & 4. 28 . \\
\hline Csíkos óriás halasi & & & & 4. 17. & 4. 21 . & 4. 28 . & 4. 16 . & 4. 18 . & 4. 20 . & 4. 26 . & 4. 28 . & 5.3. & & & \\
\hline Dániel féle renet & 4. 12 . & 4. 16 . & 4. 20 . & 4. 17. & 4. 21 . & 4. 25 . & 4. 16 . & 4. 20 . & 4. 24 . & 4. 21 . & 4. 23 . & 4. 30 . & 4. 20 . & 4. 22 . & 4. 28 . \\
\hline Daru sóvári & & & & 4. 23 . & 4. 25 . & 5.3. & & & & 4. 26 . & 4. 28 . & 5.5. & 4. 22 . & 4. 24 . & 4. 28 . \\
\hline Édes escoar & 4. 12 . & 4. 16. & 4. 18 . & 4. 17. & 4. 21 . & 4. 23 . & 4. 14 . & 4. 16 . & 4. 24 . & 4. 21 . & 4. 23 . & 4. 26 . & 4. 20 . & 4. 22 . & 4. 28 . \\
\hline Entz Rozmaring & & & & 4. 17 . & 4. 21 . & 4. 25 . & 4. 16 . & 4. 20 . & 4. 24 . & 4. 23 . & 4. 26 . & 4. 30 . & 4. 22 . & 4. 24 . & 4. 25 . \\
\hline Fekete tányéralma & & & & 4. 14 . & 4. 17 . & 4. 21 . & 4. 16 . & 4. 18 . & 4. 20 . & 4. 21 . & 4. 26 . & 4. 28 . & & & \\
\hline Gegesi piros & & & & 4. 21 . & 4. 23 . & 4. 25 . & 4. 16. & 4. 20 . & 4. 24 . & 4. 26 . & 4. 28 . & 4. 30 . & 4. 22 . & 4. 24 . & 4. 28 . \\
\hline Gomba Károly & & & & 4. 21 . & 4. 23 . & 4. 28. & 4. 20 . & 4. 22 . & 4. 24 . & 4. 26 . & 4. 28 . & 5.3. & 4. 22 . & 4. 23 . & 4. 25 . \\
\hline Gyógyi piros & & & & 4. 17. & 4. 21 . & 4. 23 . & 4. 16 . & 4. 18 . & 4. 20 . & 4. 23 . & 4. 26 . & 4. 30 . & 4. 22 . & 4. 24 . & 4. 28 . \\
\hline Harang alma & & & & 4. 23 . & 4. 25 . & 4. 30 . & 4. 20 . & 4. 24 . & 4. 28 . & 4. 26 . & 4. 28 . & 5.5. & & & \\
\hline Herceg Batthyány & 4. 18 . & 4. 20 . & 4. 23 . & 4. 17. & 4. 21 . & 4. 28 . & 4. 16. & 4. 20 . & 4. 24 . & 4. 23 . & 4. 26 . & 4. 30 . & 4. 20 . & 4. 22 . & 4. 25 . \\
\hline Hosszúfalusi & 4. 12 . & 4. 16 . & 4. 20 . & 4. 17 . & 4. 21 . & 4. 25 . & 4. 16 . & 4. 20 . & 4. 24 . & 4. 21 . & 4. 23 . & 4. 26 . & 4. 20 . & 4. 22 . & 4. 25 . \\
\hline Ízletes zöld & & & & 4. 17 . & 4. 21 . & 4. 23 . & 4. 16 . & 4. 18 . & 4. 20 . & 4. 23 . & 4. 26 . & 4. 28 . & 4. 20 . & 4. 22 . & 4. 28 . \\
\hline Jászvadóka & 4. 10 . & 4. 12 . & 4. 18. & 4. 14. & 4. 17 . & 4. 21 . & 4. 14 . & 4. 16 . & 4. 20 . & 4. 21 . & 4. 23 . & 4. 26 . & 4. 18 . & 4. 20 . & 4. 22 . \\
\hline Kanadai renet 1 & 4. 12 . & 4. 16 . & 4. 23 . & 4. 17 . & 4. 21 . & 4. 23 . & & & & 4. 23 . & 4. 26 . & 4. 28 . & 4. 20 . & 4. 22 . & 4. 25 . \\
\hline Kanadai renet 2 & & & & 4. 17. & 4. 21 . & 4. 23 . & 4. 16 . & 4. 20 . & 4. 24 . & 4. 23 . & 4. 26 . & 4. 28 . & 4. 20 . & 4. 22 . & 4. 28 . \\
\hline Kanadai renet 3 & & & & 4. 14 . & 4. 17 . & 4. 23 . & 4. 16 . & 4. 20 . & 4. 24 . & 4. 23 . & 4. 26 . & 4. 30 . & 4. 20 . & 4. 22 . & 4. 25 . \\
\hline Királyi renet & 4. 12 . & 4. 16. & 4. 23 . & 4. 17 . & 4. 21 . & 4. 25 . & 4. 16 . & 4. 20 . & 4. 24. & & & & 4. 20 . & 4. 22 . & 4. 28 . \\
\hline Kisasszony & & & & 4. 17. & 4. 21 . & 4. 25. & 4. 16. & 4. 20 . & 4. 28. & 4. 26. & 4. 28. & 4. 30 . & 4. 22. & 4. 28. & 4. 30 . \\
\hline
\end{tabular}




\section{5. melléklet. (folyt.)}

\begin{tabular}{|c|c|c|c|c|c|c|c|c|c|c|c|c|c|c|c|}
\hline \multirow[b]{2}{*}{ Vizsgált fajta } & \multicolumn{3}{|c|}{2007} & \multicolumn{3}{|c|}{2008} & \multicolumn{3}{|c|}{2009} & \multicolumn{3}{|c|}{2010} & \multicolumn{3}{|c|}{2011} \\
\hline & $\begin{array}{l}\text { Virágzás } \\
\text { kezdete }\end{array}$ & $\begin{array}{c}\begin{array}{c}\text { Fö- } \\
\text { virágzás }\end{array} \\
\end{array}$ & $\begin{array}{l}\text { Virágzás } \\
\text { vége }\end{array}$ & $\begin{array}{l}\text { Virágzás } \\
\text { kezdete }\end{array}$ & $\begin{array}{c}\begin{array}{c}\text { Fö- } \\
\text { virágzás }\end{array} \\
\end{array}$ & $\begin{array}{c}\text { Virágzás } \\
\text { vége }\end{array}$ & \begin{tabular}{|l|l|}
$\begin{array}{l}\text { Virágzás } \\
\text { kezdete }\end{array}$ \\
\end{tabular} & $\begin{array}{c}\text { Fö- } \\
\text { virágzás }\end{array}$ & $\begin{array}{c}\text { Virágzás } \\
\text { vége }\end{array}$ & $\begin{array}{l}\text { Virágzás } \\
\text { kezdete }\end{array}$ & $\begin{array}{c}\begin{array}{c}\text { Fö- } \\
\text { virágzás }\end{array} \\
\end{array}$ & $\begin{array}{c}\text { Virágzás } \\
\text { vége }\end{array}$ & $\begin{array}{l}\text { Virágzás } \\
\text { kezdete }\end{array}$ & $\begin{array}{c}\begin{array}{c}\text { Fö- } \\
\text { virágzás }\end{array} \\
\end{array}$ & $\begin{array}{l}\text { Virágzás } \\
\text { vége }\end{array}$ \\
\hline Lóci cirmos alma & 4.16. & 4. 18. & 4.23. & 4.17. & 4.21 & 4.23. & 4. 16. & 4.18. & 4. 20. & 4. 21. & 4. 23. & 4.28 & & & \\
\hline Lóci édes almája & & & & 4. 14 . & 4. 17 . & 4. 23 . & 4. 16 . & 4. 18 . & 4. 20 . & 4. 21 . & 4. 23 . & 4. 28 . & 4. 20 . & 4. 22 . & 4. 28 . \\
\hline Londoni pepin & 4. 16. & 4. 18 . & 4. 27. & 4. 21 . & 4. 23 . & 4. 30 . & 4. 16. & 4. 20 . & 4. 28 . & 4. 26. & 4. 28 . & 5.5. & 4. 22 . & 4. 28 . & 4. 30 . \\
\hline Marosszéki piros & & & & 4. 23 . & 4. 25 . & 4. 30 . & 4. 20 . & 4. 24 . & 4. 28 . & 4. 28 . & 4. 30 . & 5. 3. & 4. 24 . & 4. 28 . & 4. 30 . \\
\hline Masánszki & & & & 4. 21 . & 4. 23 . & 4. 30 . & 4. 16 . & 4. 20 . & 4. 28 . & 4. 26 . & 4. 28 . & 5. 3 . & 4. 22 . & 4. 28 . & 4. 30 . \\
\hline Máté Dénes & & & & 4. 17 . & 4. 21 . & 4. 25 . & 4. 16 . & 4. 18 . & 4. 20 . & 4. 23 . & 4. 26 . & 5. 3. & 4. 22 . & 4. 28 . & 4. 30 . \\
\hline Mosolygós batul & & & & 4. 21 . & 4. 23 . & 4. 28 . & 4. 16 . & 4. 20 . & 4. 24 . & 4. 23 . & 4. 26. & 4. 30 . & 4. 20 . & 4. 22 . & 4. 25 . \\
\hline Nemes sóvári & & & & 4. 17 . & 4. 21 . & 4. 23 . & 4. 16 . & 4. 20 . & 4. 24 . & & & & 4. 22 . & 4. 24 . & 4. 28 . \\
\hline Nemes szercsika & & & & 4. 17. & 4. 21 . & 4. 23 . & 4. 16 . & 4. 20 . & 4. 24 . & 4. 23 . & 4. 26 . & 4. 30 . & 4. 20 . & 4. 22 . & 4. 25 . \\
\hline Ontario & & & & 4. 17 . & 4. 21 . & 4. 25 . & 4. 16. & 4. 20 . & 4. 24 . & 4. 23 . & 4. 26 . & 5.3. & 4. 20 . & 4. 22 . & 4. 28 . \\
\hline Orbai alma & 4. 10 . & 4. 12 . & 4. 16. & 4. 14. & 4. 17 . & 4. 21 . & 4. 14 . & 4. 16 . & 4. 20 . & & & & 4. 18 . & 4. 20 . & 4. 25 . \\
\hline Sándor cár & & & & 4. 21 . & 4. 23 . & 4. 30 . & 4. 16. & 4. 20 . & 4. 24 . & 4. 26 . & 4. 30 . & 5.5. & 4. 20 . & 4. 22 . & 4. 28 . \\
\hline Sárga szépvirágú & 4. 12 . & 4. 16. & 4. 18 . & 4. 17. & 4. 21 . & 4. 30 . & 4. 16. & 4. 20 . & 4. 24 . & 4. 23 . & 4. 26 . & 4. 28. & 4. 20 . & 4. 22 . & 4. 25 . \\
\hline Sikulai & 4. 16. & 4. 23 . & 4. 27 . & 4. 17 . & 4. 21 . & 4. 23 . & 4. 16 . & 4. 20 . & 4. 24 . & 4. 23 . & 4. 26 . & 4. 30 . & 4. 22 . & 4. 24 . & 4. 28 . \\
\hline Simonffy piros & 4. 16 . & 4. 18 . & 4. 27. & 4. 17 . & 4. 21 . & 4. 28 . & & & & 4. 23 . & 4. 26 . & 5.3. & & & \\
\hline Sóvári nobil & & & & 4. 23 . & 4. 25 . & 4. 30 . & & & & 4. 26 . & 4. 30 . & 5. 5 . & & & \\
\hline Szabadkai szercsika & & & & & & & 4. 16. & 4. 20 . & 4. 24 . & 4. 26 . & 4. 28 . & 5. 3. & 4. 20 . & 4. 22 . & 4. 28 . \\
\hline Szászpap alma & & & & 4. 21 . & 4. 23 . & 4. 28 . & 4. 16 . & 4. 20 . & 4. 24 . & 4. 23 . & 4. 26 . & 4. 30 . & 4. 20 . & 4. 22 . & 4. 25 . \\
\hline Széchenyi renet & 4. 10 . & 4. 12 . & 4. 18. & 4. 21 . & 4. 23 . & 4. 28 . & 4. 14 . & 4. 16. & 4. 24 . & 4. 23 . & 4. 26 . & 4. 28 . & 4. 20 . & 4. 22 . & 4. 25 . \\
\hline Tartós Gusztáv & 4. 16. & 4. 18 . & 4. 23 . & 4. 21 . & 4. 23 . & 5.3. & 4. 16 . & 4. 20 . & 4. 28 . & 4. 26 . & 4. 28 . & 5.5. & 4. 22 . & 4. 28 . & 4. 30 . \\
\hline Tordai alma & & & & 4. 17 . & 4. 21 . & 4. 23 . & 4. 14. & 4. 16. & 4. 20 . & 4. 23 . & 4. 26 . & 4. 30 . & 4. 20 . & 4. 22 . & 4. 25 . \\
\hline Tordai piros kálvil & & & & & & & & & & 4. 26 . & 4. 28 . & 5.3. & 4. 24 . & 4. 28 . & 4. 30 . \\
\hline Tükör alma & & & & 4. 21 . & 4. 23 . & 4. 28 . & & & & 4. 23 . & 4. 26 . & 5.3. & & & \\
\hline Vajki alma & 4. 12 . & 4. 16 . & 4. 18 . & 4. 21 . & 4. 23 . & 4. 30 . & 4. 16 . & 4. 20 . & 4. 24 . & 4. 23 . & 4. 26 . & 4. 30 . & 4. 22 . & 4. 28 . & 4. 30 . \\
\hline Vilmos renet & 4. 16. & 4. 18 . & 4. 23 . & 4. 21 . & 4. 23 . & 4. 28 . & 4. 20 . & 4. 24 . & 4. 28 . & 4. 23 . & 4. 26 . & 5.3. & 4. 22 . & 4. 28 . & 4. 30 . \\
\hline Zöld batul & 4. 20 . & 4. 27. & 4. 30. & 4. 25 . & 4. 30. & 5. 10. & & & & & & & 4. 28. & 4. 30. & 5.3. \\
\hline \multicolumn{16}{|l|}{ Kontroll: } \\
\hline Reglindis & 4. 12 . & 4. 15 . & 4. 20 . & 4. 12 . & 4. 16. & 4. 22 . & 4. 13. & 4. 15 . & 4. 18. & 4. 20 . & 4. 23 . & 4. 26. & & & \\
\hline Florina & 4. 14. & 4. 17. & 4. 21 . & 4. 14. & 4. 18 . & 4. 21 . & 4. 15 . & 4. 17. & 4. 21 . & 4. 23 . & 4. 27. & 4. 30 . & 4. 21 . & 4. 24 . & 4. 28 . \\
\hline Rewena & & & & 4. 17. & 4. 21. & 4. 30. & 4. 16. & 4. 19. & 4. 22. & 4. 26. & 4. 30. & 5. 3. & 4. 24. & 4. 27. & 5.1. \\
\hline
\end{tabular}


6. melléklet. A virág, levél, gyümölcs átlagértékei (Soroksár, 2007-2011)

\begin{tabular}{|c|c|c|c|c|c|c|c|c|c|c|c|c|c|c|c|c|c|c|c|c|c|c|c|c|c|c|c|c|}
\hline \multirow{2}{*}{ Fajta } & \multicolumn{4}{|c|}{$\begin{array}{c}\text { Virág átmérője } \\
\text { (átlag) }\end{array}$} & \multicolumn{4}{|c|}{$\begin{array}{l}\text { Levéllemez } \\
\text { hosszúsága } \\
\text { (átlag) }\end{array}$} & \multicolumn{4}{|c|}{$\begin{array}{c}\text { Levéllemez } \\
\text { szélessége } \\
\text { (átlag) }\end{array}$} & \multicolumn{4}{|c|}{$\begin{array}{c}\text { Levélnyél } \\
\text { hosszúsága } \\
\text { (átlag) }\end{array}$} & \multicolumn{6}{|c|}{$\begin{array}{c}\text { Gyümölcs magassága } \\
\text { (átlag) }\end{array}$} & \multicolumn{6}{|c|}{$\begin{array}{c}\text { Gyümöles átmérője } \\
\text { (átlag) }\end{array}$} \\
\hline & હิ & 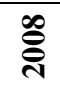 & ڤે̊ิ & 禀 & હิ & 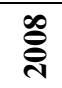 & ڤ્ఠે & 宸 & હે & 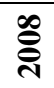 & જ્తి & $\frac{0,0}{2}$ & હิ & ஓ્ণิ & ڤ્ఠิ & 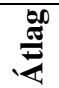 & હิ & 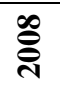 & હે & 을 & $\overline{\bar{\lambda}}$ & 䍿 & હે & 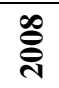 & હેઁે & 옹 & $\overline{\overline{\text { ন }}}$ & $\frac{0}{0}$ \\
\hline Bánffy Pál & & 51 & & 51 & 84 & & & 84 & 65 & & & 65 & 25 & & & 25 & & 65 & & & & 65 & & 85 & & & & 85 \\
\hline Batul 1 & & & 39 & 39 & 75 & & 67 & 71 & 61 & & 52 & 57 & 22 & & 22 & 22 & & & 67 & & & 67 & & & 78 & & & 78 \\
\hline Batul 2 & 36 & 42 & 42 & 40 & 73 & 77 & 68 & 73 & 61 & 58 & 53 & 57 & 22 & 23 & 23 & 23 & & & 63 & & & 63 & & & 75 & & & 75 \\
\hline Batul 3 & 43 & & 43 & 43 & 69 & 68 & 69 & 69 & 53 & 51 & 53 & 52 & 21 & 23 & 22 & 22 & & & 62 & & & 62 & & & 74 & & & 74 \\
\hline Baumann renet & & 52 & & 52 & 75 & & & 75 & 56 & & & 56 & 30 & & & 30 & & & & 70 & & 70 & & & & 81 & & 81 \\
\hline Beregi sóvári 1 & 47 & 47 & 39 & 44 & 80 & & 83 & 82 & 54 & & 59 & 57 & 16 & & 19 & 18 & & 49 & 49 & & & 49 & & 67 & 68 & & & 68 \\
\hline Beregi sóvári 2 & 59 & 59 & 46 & 55 & 84 & 81 & 80 & 82 & 60 & 62 & 55 & 59 & 18 & 20 & 22 & 20 & & 67 & 63 & & & 65 & & 80 & 76 & & & 78 \\
\hline Börkormos renet & 41 & 47 & & 44 & 79 & 83 & & 81 & 59 & 57 & & 58 & 20 & 25 & & 23 & & 63 & & 54 & & 59 & & 77 & & 68 & & 73 \\
\hline Budai Domokos & 43 & & & 43 & 82 & & & 82 & 56 & & & 56 & 26 & & & 26 & & & & & & & & & & & & \\
\hline Budai Ignác & 41 & 50 & & 46 & 93 & & & 93 & 66 & & & 66 & 26 & & & 26 & & 62 & & & & 62 & & 77 & & & & 77 \\
\hline Cigány alma & 58 & 62 & & 60 & 96 & 94 & & 95 & 62 & 63 & & 63 & 25 & 24 & & 25 & 61 & & & & & 61 & 76 & & & & & 76 \\
\hline Cserepánya & & 59 & & 59 & 87 & & & 87 & 59 & & & 59 & 16 & & & 16 & & 62 & & & & 62 & & 85 & & & & 85 \\
\hline Csíkos óriás halasi & 51 & 56 & & 54 & 86 & & & 86 & 71 & & & 71 & 18 & & & 18 & & 67 & & & & 67 & & 82 & & & & 82 \\
\hline Dániel féle renet & 61 & 66 & & 64 & 96 & 93 & & 95 & 60 & 61 & & 61 & 24 & 22 & & 23 & & 65 & 67 & 63 & & 65 & & 79 & 83 & 80 & & 81 \\
\hline Daru sóvári & & 52 & & 52 & 94 & & 92 & 93 & 71 & & 67 & 69 & 18 & & 18 & 18 & & 58 & & & & 58 & & 72 & & & & 72 \\
\hline Édes escoar & & & & & 91 & & & 91 & 59 & & & 59 & 25 & & & 25 & & 56 & & & & 56 & & 70 & & & & 70 \\
\hline Entz Rozmaring & & 55 & & 55 & 83 & & & 83 & 69 & & & 69 & 18 & & & 18 & & 65 & & 68 & 73 & 69 & & 68 & & 73 & 79 & 73 \\
\hline Fekete tányéralma & & 57 & & 57 & 97 & & & 97 & 70 & & & 70 & 24 & & & 24 & & 51 & & 50 & & 51 & & 70 & & 72 & & 71 \\
\hline Gegesi piros & 53 & & & 53 & 99 & & & 99 & 66 & & & 66 & 31 & & & 31 & & 64 & & & & 64 & & 83 & & & & 83 \\
\hline Gomba Károly & & 61 & & 61 & 89 & & & 89 & 66 & & & 66 & 21 & & & 21 & & 70 & & & & 70 & & 81 & & & & 81 \\
\hline Gyógyi piros & 61 & 57 & & 59 & 92 & & & 92 & 68 & & & 68 & 33 & & & 33 & & & & & & & & & & & & \\
\hline Harang alma & & 51 & & 51 & 90 & & & 90 & 71 & & & 71 & 17 & & & 17 & & 71 & & & & 71 & & 78 & & & & 78 \\
\hline Herceg Batthyány & 44 & 44 & & 44 & 95 & 99 & & 97 & 63 & 61 & & 62 & 28 & 31 & & 30 & & 60 & & & & 60 & & 71 & & & & 71 \\
\hline Hosszúfalusi & 41 & 40 & & 41 & 86 & 89 & & 88 & 53 & 53 & & 53 & 22 & 22 & & 22 & & 53 & & & & 53 & & 72 & & & & 72 \\
\hline Húsvéti rozmaring & & & & & & 95 & & 95 & & 66 & & 66 & & 20 & & 20 & & & & 73 & 73 & 73 & & & & 80 & 79 & 80 \\
\hline Ízletes zöld & & 50 & & 50 & 89 & & & 89 & 60 & & & 60 & 22 & & & 22 & & 67 & & & & 67 & & 83 & & & & 83 \\
\hline Jászvadóka & 46 & 46 & & 46 & 81 & 78 & & 80 & 48 & 48 & & 48 & 28 & 26 & & 27 & & 53 & & & & 53 & & 62 & & & & 62 \\
\hline Kanadai renet 1 & 51 & 59 & & 55 & 91 & 92 & & 92 & 74 & 70 & & 72 & 26 & 25 & & 26 & & & 76 & 75 & & 76 & & & 96 & 91 & & 94 \\
\hline Kanadai renet 2 & & 57 & & 57 & 87 & & & 87 & 66 & & & 66 & 28 & & & 28 & & & 69 & 67 & & 68 & & & 88 & 86 & & 87 \\
\hline Kanadai renet 3 & & 58 & & 58 & 86 & & & 86 & 72 & & & 72 & 27 & & & 27 & & 70 & & 72 & & 71 & & 92 & & 92 & & 92 \\
\hline Királyi renet & 58 & & & 58 & 93 & 99 & & 96 & 68 & 66 & & 67 & 27 & 31 & & 29 & & & 67 & & & 67 & & & 88 & & & 88 \\
\hline
\end{tabular}


6. melléklet. (folyt.)

\begin{tabular}{|c|c|c|c|c|c|c|c|c|c|c|c|c|c|c|c|c|c|c|c|c|c|c|c|c|c|c|c|c|}
\hline \multirow{2}{*}{ Fajta } & \multicolumn{4}{|c|}{$\begin{array}{c}\text { Virág átmérője } \\
\text { (átlag) }\end{array}$} & \multicolumn{4}{|c|}{$\begin{array}{c}\text { Levéllemez } \\
\text { hosszúsága } \\
\text { (átlag) }\end{array}$} & \multicolumn{4}{|c|}{$\begin{array}{c}\text { Levéllemez } \\
\text { szélessége } \\
\text { (átlag) }\end{array}$} & \multicolumn{4}{|c|}{$\begin{array}{l}\text { Levélnyél } \\
\text { hosszúsága } \\
\text { (átlag) }\end{array}$} & \multicolumn{6}{|c|}{$\begin{array}{c}\text { Gyümölcs magassága } \\
\text { (átlag) }\end{array}$} & \multicolumn{6}{|c|}{$\begin{array}{c}\text { Gyümöles átmérője } \\
\text { (átlag) }\end{array}$} \\
\hline & సิ & 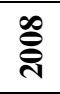 & ఠิ & 紫 & હิ & 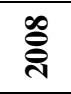 & बे & 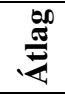 & 홍 & 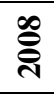 & ڤે̊ิ & 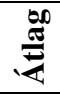 & હิ) & 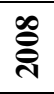 & बे̊ి & 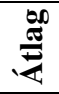 & હิ & 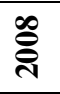 & 을 & 을 & $\overline{\bar{\pi}}$ & 傿 & ริ & 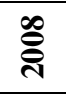 & ڤิ & 을 & 戸్ & 筀 \\
\hline Kisasszony & & 45 & & 45 & & 73 & & 73 & & 55 & & 55 & & 19 & & 19 & & 55 & & & & 55 & & 72 & & & & 72 \\
\hline mos alma & & 58 & & 58 & 93 & 87 & & 90 & 61 & 56 & & 59 & 31 & 30 & & 31 & & 65 & & & & 65 & & 80 & & & & 80 \\
\hline Lóci édes almája & & & & & 91 & & & 91 & 59 & & & 59 & 23 & & & 23 & & 73 & & & & 73 & & 88 & & & & 88 \\
\hline Londoni pepin & 48 & 54 & & 51 & 82 & 82 & & 82 & 51 & 48 & & 50 & 26 & 25 & & 26 & & 60 & & & & 60 & & 81 & & & & 81 \\
\hline Marosszéki piros & 39 & & & 39 & 85 & 88 & & 87 & 57 & 53 & & 55 & 25 & 28 & & 27 & & & & & & & & & & & & \\
\hline Masánszki & & & & & 90 & & & 90 & 68 & & & 68 & 25 & & & 25 & & 73 & & & & 73 & & 82 & & & & 82 \\
\hline Máté & 46 & 52 & & 49 & 82 & & & 82 & 55 & & & 55 & 25 & & & 25 & & 57 & & & & 57 & & 77 & & & & 77 \\
\hline Mosolygós batul & & & 37 & 37 & & & 66 & 66 & & & 53 & 53 & & & 21 & 21 & & & 64 & & & 64 & & & 76 & & & 76 \\
\hline Neme & & & 50 & 50 & 81 & & 88 & 85 & 59 & & 60 & 60 & 16 & & 19 & 18 & & & & & & & & & & & & \\
\hline Neme & & 54 & & 54 & 84 & & & 84 & 58 & & & 58 & 19 & & & 19 & & & & & & & & & & & & \\
\hline Nyári fon & & & & & & 106 & & 106 & & 69 & & 69 & & 28 & & 28 & & & & 69 & 74 & 72 & & & & 94 & 96 & 95 \\
\hline Ontario & 51 & 52 & & 52 & 84 & & & 84 & 63 & & & 63 & 30 & & & 30 & & 73 & & & & 73 & & 92 & & & & 92 \\
\hline Orbai alma & 53 & 56 & & 55 & 81 & 92 & & 87 & 61 & 64 & & 63 & 23 & 25 & & 24 & & & & & & & & & & & & \\
\hline Sándo & & 60 & & 60 & & 88 & & 88 & & 69 & & 69 & & 18 & & 18 & & 64 & & & & 64 & & 83 & & & & 83 \\
\hline Sárga & & & & & & 96 & & 96 & & 51 & & 51 & & 25 & & 25 & & 76 & & & & 76 & & 84 & & & & 84 \\
\hline Siku & 48 & 49 & & 49 & 87 & 99 & & 93 & 60 & 65 & & 63 & 25 & 27 & & 26 & 51 & 59 & & & & 55 & 70 & 80 & & & & 75 \\
\hline Simo & 42 & 47 & & 45 & 83 & 73 & & 78 & 58 & 53 & & 56 & 26 & 24 & & 25 & & 53 & & & & 53 & & 66 & & & & 66 \\
\hline Sóvári nobil & & 53 & 47 & 50 & 97 & & 91 & 94 & 68 & & 66 & 67 & 19 & & 20 & 20 & & 73 & & & & 73 & & 88 & & & & 88 \\
\hline Szabadkai szercsika & 45 & & & 45 & 72 & & & 72 & 58 & & & 58 & 20 & & & 20 & 56 & & & & & 56 & 73 & & & & & 73 \\
\hline Szászp & & 48 & & 48 & 82 & & & 82 & 55 & & & 55 & 22 & & & 22 & & & & & & & & & & & & \\
\hline Széc & 50 & 48 & & 49 & 84 & 79 & & 82 & 63 & 51 & & 57 & 24 & 28 & & 26 & & & 56 & 61 & & 59 & & & 67 & 74 & & 71 \\
\hline Tartós Gusztáv & & 54 & & 54 & 81 & 83 & & 82 & 65 & 72 & & 69 & 27 & 27 & & 27 & & 66 & & & & 66 & & 77 & & & & 77 \\
\hline Tord & & 64 & & 64 & 98 & & & 98 & 66 & & & 66 & 25 & & & 25 & & & & 68 & 72 & 70 & & & & 90 & 95 & 93 \\
\hline & & & & & 73 & & & 73 & 52 & & & 52 & 27 & & & 27 & & & & & & & & & & & & \\
\hline Tükö1 & & 48 & & 48 & 88 & & & 88 & 57 & & & 57 & 23 & & & 23 & & 63 & & & & 63 & & 80 & & & & 80 \\
\hline Vajki al & 57 & 56 & & 57 & 83 & 92 & & 88 & 65 & 66 & & 66 & 20 & 21 & & 21 & & & & & & & & & & & & \\
\hline Vilmos renet & 46 & 51 & & 49 & 97 & 101 & & 99 & 64 & 63 & & 64 & 22 & 26 & & 24 & & & & 66 & & 66 & & & & 81 & & 81 \\
\hline Zöld batul & 51 & & 47 & 49 & & 90 & 81 & 86 & & 57 & 50 & 54 & & 31 & 28 & 30 & & & 74 & & & 74 & & & 80 & & & 80 \\
\hline Zöld só & & & & & 88 & & 88 & 88 & 68 & & 60 & 64 & 19 & & 24 & 22 & & & & & & & & & & & & \\
\hline Átlag & 49 & 53 & 43 & 51 & 86 & 88 & 79 & 87 & 62 & 60 & 57 & 61 & 24 & 25 & 22 & 24 & 56 & 63 & & 66 & 73 & 64 & 73 & 78 & 79 & & 87 & 79 \\
\hline Minimum & 36 & 40 & 37 & 37 & 69 & 68 & 66 & 66 & 48 & 48 & 50 & 48 & 16 & 18 & 18 & 16 & 51 & 49 & 49 & 50 & 72 & 49 & 70 & 62 & 67 & 68 & 79 & 62 \\
\hline Maximum & 61 & 66 & 50 & 64 & 99 & 106 & 92 & 106 & 74 & 72 & 67 & 72 & 33 & 31 & 28 & 33 & 61 & 76 & 76 & 75 & 74 & 76 & 76 & 92 & 96 & 94 & 96 & 95 \\
\hline
\end{tabular}




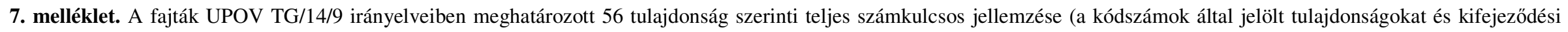
fokozatokat lásd a 2 . mellékletben)

\begin{tabular}{|c|c|c|c|c|c|c|c|c|c|c|c|c|c|c|c|c|c|c|c|c|c|c|c|c|c|c|c|c|}
\hline Tulajdonság & 1. & 2. & 3. & 4. & 5. & 6. & 7. & 8. & 9. & 10. & 11. & 12. & 13. & 14. & 15. & 16. & 17. & 18. & 19. & 20. & 21. & 22. & 24. & 25. & 26. & 27. & 28. & 29. \\
\hline Bánffy Pál & 5 & 2 & 2 & 2 & 5 & 3 & 4 & 1 & 5 & 2 & 3 & 7 & 3 & 5 & 3 & 2 & 5 & 3 & 4 & 3 & 3 & 2 & 7 & 5 & 7 & 5 & 7 & 1 \\
\hline Batul 1 & 5 & 2 & 2 & 2 & 5 & 3 & 2 & 5 & 7 & 2 & 1 & 3 & 3 & 5 & 5 & 2 & 5 & 5 & 5 & 1 & 3 & 2 & 7 & 7 & 5 & 5 & 6 & 1 \\
\hline Batul 2 & 5 & 2 & 2 & 2 & 5 & 3 & 2 & 5 & 7 & 2 & 1 & 5 & 3 & 5 & 5 & 2 & 5 & 5 & 5 & 1 & 3 & 2 & 4 & 5 & 5 & 5 & 6 & 1 \\
\hline Batul 3 & 5 & 2 & 2 & 2 & 5 & 3 & 2 & 5 & 7 & 2 & 1 & 3 & 3 & 5 & 5 & 2 & 5 & 5 & 5 & 1 & 3 & 2 & 6 & 5 & 5 & 5 & 6 & 1 \\
\hline Baumann renet & 5 & 2 & 2 & 2 & 3 & 5 & 3 & 5 & 5 & 2 & 1 & 5 & 3 & 3 & 3 & 3 & 7 & 5 & 4 & 5 & 2 & 2 & 6 & 7 & 7 & 7 & 2 & 1 \\
\hline Beregi sóvári 1 & 3 & 2 & 1 & 2 & 7 & 3 & 4 & 7 & 7 & 2 & 3 & 5 & 5 & 7 & 4 & 3 & 3 & 5 & 4 & 3 & 2 & 3 & 4 & 3 & 3 & 3 & 7 & 1 \\
\hline Beregi sóvári 2 & 5 & 2 & 3 & 2 & 5 & 5 & 3 & 7 & 7 & 2 & 3 & 5 & 5 & 5 & 1 & 3 & 3 & 3 & 4 & 7 & 3 & 2 & 5 & 5 & 5 & 5 & 6 & 1 \\
\hline Bőrkormos renet & 3 & 2 & 2 & 2 & 5 & 3 & 1 & 7 & 7 & 1 & 3 & 5 & 5 & 5 & 4 & 2 & 5 & 7 & 3 & 3 & 2 & 2 & 5 & 3 & 3 & 5 & 7 & 1 \\
\hline Budai Domokos & 5 & 2 & 2 & 1 & 7 & 3 & 3 & 1 & 7 & 1 & 3 & 3 & 5 & 5 & 5 & 2 & 5 & 3 & 4 & 3 & 1 & 2 & 4 & 5 & 3 & 5 & 6 & 1 \\
\hline Budai Ignác & 3 & 2 & 2 & 2 & 3 & 3 & 5 & 5 & 3 & 2 & 5 & 7 & 5 & 5 & 3 & 1 & 5 & 5 & 5 & 3 & 2 & 3 & 5 & 5 & 5 & 5 & 6 & 1 \\
\hline Cigány alma & 7 & 2 & 2 & 2 & 5 & 5 & 2 & 5 & 7 & 2 & 7 & 5 & 5 & 5 & 4 & 2 & 5 & 3 & 3 & 7 & 3 & 2 & 6 & 5 & 5 & 5 & 7 & 1 \\
\hline Cserepánya & 5 & 2 & 2 & 2 & 5 & 5 & 5 & 9 & 5 & 2 & 5 & 5 & 5 & 5 & 4 & 3 & 3 & 3 & 4 & 7 & 3 & 3 & 7 & 5 & 7 & 3 & 7 & 1 \\
\hline Csíkos óriás halasi & 3 & 2 & 3 & 2 & 5 & 5 & 1 & 7 & 3 & 2 & 3 & 7 & 3 & 5 & 3 & 2 & 3 & 5 & 4 & 5 & 3 & 2 & 9 & 7 & 7 & 5 & 7 & 2 \\
\hline Dániel féle renet & 5 & 2 & 3 & 2 & 5 & 5 & 4 & 7 & 7 & 2 & 7 & 5 & 7 & 5 & 4 & 1 & 5 & 3 & 3 & 7 & 3 & 2 & 5 & 5 & 5 & 5 & 7 & 1 \\
\hline Daru sóvári & 5 & 2 & 2 & 2 & 7 & 7 & 2 & 9 & 5 & 2 & 5 & 7 & 3 & 7 & 4 & 3 & 3 & 7 & 3 & 5 & 3 & 3 & 5 & 5 & 5 & 5 & 2 & 1 \\
\hline Édes escoar & 3 & 2 & 2 & 3 & 3 & 5 & 3 & 1 & 7 & 2 & 5 & 5 & 7 & 5 & 4 & 2 & 5 & 5 & 4 & 5 & 1 & 2 & 3 & 5 & 3 & 5 & 7 & 1 \\
\hline Entz Rozmaring & 5 & 2 & 2 & 2 & 5 & 7 & 2 & 5 & 7 & 2 & 3 & 7 & 3 & 7 & 4 & 1 & 3 & 5 & 4 & 7 & 3 & 2 & 6 & 7 & 5 & 7 & 2 & 1 \\
\hline Fekete tányéralma & 3 & 2 & 3 & 2 & 5 & 7 & 4 & 9 & 7 & 2 & 7 & 7 & 5 & 5 & 4 & 3 & 5 & 3 & 4 & 7 & 1 & 3 & 5 & 3 & 5 & 7 & 7 & 1 \\
\hline Gegesi piros & 5 & 2 & 2 & 3 & 7 & 7 & 4 & 5 & 7 & 2 & 7 & 7 & 5 & 5 & 3 & 1 & 7 & 5 & 4 & 7 & 2 & 2 & 7 & 5 & 7 & 5 & 7 & 1 \\
\hline Gomba Károly & 5 & 2 & 3 & 3 & 5 & 7 & 3 & 7 & 3 & 2 & 5 & 7 & 5 & 5 & 5 & 2 & 5 & 5 & 4 & 7 & 3 & 3 & 7 & 7 & 7 & 7 & 2 & 1 \\
\hline Gyógyi piros & 3 & 2 & 2 & 2 & 3 & 5 & 2 & 1 & 3 & 1 & 5 & 7 & 3 & 5 & 3 & 1 & 7 & 5 & 4 & 7 & 1 & 2 & 5 & 5 & 5 & 5 & 7 & 1 \\
\hline Harang alma & 3 & 2 & 3 & 2 & 3 & 3 & 4 & 5 & 3 & 2 & 5 & 7 & 3 & 5 & 3 & 2 & 7 & 7 & 3 & 5 & 3 & 3 & 7 & 7 & 5 & 7 & 2 & 1 \\
\hline Herceg Batthyány & 5 & 2 & 2 & 2 & 3 & 5 & 3 & 7 & 5 & 2 & 7 & 5 & 7 & 5 & 3 & 3 & 7 & 3 & 4 & 3 & 2 & 3 & 7 & 5 & 5 & 5 & 6 & 1 \\
\hline Hosszúfalusi & 3 & 2 & 2 & 2 & 5 & 1 & 5 & 9 & 7 & 2 & 5 & 3 & 7 & 5 & 3 & 1 & 5 & 5 & 4 & 1 & 2 & 3 & 5 & 3 & 5 & 3 & 7 & 1 \\
\hline Húsvéti rozmaring & 5 & 2 & 2 & 2 & 5 & 7 & 2 & 5 & 7 & 2 & 5 & 7 & 5 & 5 & 4 & 1 & 3 & 7 & 4 & 7 & 3 & 2 & 6 & 7 & 5 & 7 & 2 & 1 \\
\hline Ízletes zöld & 5 & 2 & 2 & 3 & 5 & 5 & 3 & 7 & 3 & 1 & 5 & 5 & 5 & 5 & 3 & 1 & 5 & 3 & 4 & 5 & 3 & 2 & 6 & 7 & 7 & 5 & 6 & 1 \\
\hline Jászvadóka & 3 & 2 & 2 & 2 & 3 & 7 & 4 & 7 & 3 & 2 & 3 & 3 & 5 & 3 & 3 & 3 & 5 & 3 & 3 & 3 & 2 & 2 & 2 & 3 & 3 & 7 & 6 & 1 \\
\hline Kanadai renet 1 & 7 & 2 & 2 & 1 & 7 & 7 & 3 & 5 & 7 & 2 & 5 & 7 & 3 & 5 & 5 & 2 & 5 & 3 & 3 & 7 & 3 & 3 & 9 & 7 & 7 & 5 & 7 & 1 \\
\hline Kanadai renet 2 & 7 & 2 & 2 & 1 & 7 & 7 & 3 & 5 & 7 & 2 & 5 & 7 & 3 & 5 & 5 & 2 & 7 & 3 & 4 & 7 & 3 & 3 & 9 & 7 & 7 & 5 & 7 & 1 \\
\hline Kanadai renet 3 & 7 & 2 & 2 & 1 & 7 & 7 & 3 & 5 & 7 & 2 & 5 & 7 & 3 & 5 & 5 & 2 & 7 & 3 & 4 & 7 & 3 & 3 & 9 & 7 & 7 & 5 & 7 & 1 \\
\hline Királyi renet & 5 & 2 & 2 & 2 & 7 & 5 & 1 & 7 & 5 & 2 & 7 & 7 & 5 & 5 & 4 & 2 & 7 & 3 & 4 & 7 & 2 & 3 & 7 & 7 & 7 & 5 & 7 & 1 \\
\hline Kisasszony & 5 & 2 & 2 & 2 & 3 & 7 & 1 & 9 & 7 & 1 & 1 & 3 & 3 & 5 & 3 & 3 & 3 & 3 & 4 & 3 & 3 & 3 & 5 & 3 & 5 & 5 & 6 & 1 \\
\hline Lóci cirmos alma & 7 & 2 & 2 & 3 & 5 & 5 & 3 & 3 & 7 & 1 & 5 & 5 & 5 & 5 & 5 & 3 & 7 & 5 & 4 & 5 & 1 & 3 & 6 & 5 & 5 & 5 & 6 & 1 \\
\hline
\end{tabular}




\section{7. melléklet. (folyt.)}

Londoni pepin

Marosszéki piros

Masánszki

Máté Dénes

Mosolygós batul

Nemes sóvári

Nemes szercsika

Nyári fontos

Ontario

Orbai alma

1. 2.3 . 8. 9.

11. 12. 13.14 .15$.

\begin{tabular}{cccccccccccc} 
17. & 18. & 19. & 20. & 21. & 22. & 24. & 25. & 26. & 27. & 28. & 29. \\
\hline 5 & 7 & 3 & 7 & 3 & 2 & 8 & 7 & 7 & 5 & 6 & 1
\end{tabular}

Sándor cár

\begin{tabular}{lll}
5 & 2 & 2 \\
\hline
\end{tabular}

Sárga szépvirágú

Sikulai

Simonffy piros

Sóvári nobil

Szabadkai szercsika

Szászpap alma

Széchenyi renet

Tartós Gusztáv

Tordai alma

$3 \quad 2 \quad 2$

\begin{tabular}{ll}
2 & 5 \\
2 & 3 \\
\hline 1 & 5 \\
\hline
\end{tabular}

$\begin{array}{lll}5 & 2 & 2\end{array}$

Tordai piros kálvil

Tükör alma

Vajki alma

Vilmos renet

Zöld batul

Zöld sóvári

$\begin{array}{lll}5 & 2 & 2 \\ 3 & 2 & 2\end{array}$

$\begin{array}{ll}2 & 5 \\ 2 & 3\end{array}$

$\begin{array}{llll}2 & 7 & 3\end{array}$

$\begin{array}{lllll}2 & 3 & 7 & 1 & 7\end{array}$

$\begin{array}{ll}2 & 5 \\ 3 & 7\end{array}$

$\begin{array}{lll}1 & 9 \\ 1 & 7\end{array}$

1

$\begin{array}{lll}1 & 3 & 7 \\ 4 & 3 & 3\end{array}$

$\begin{array}{llllll}2 & 5 & 5 & 5 & 5 & 3 \\ 2 & 3 & 3 & 7 & 5 & 1\end{array}$

\begin{tabular}{lll}
2 & 3 & 3 \\
2 & 3 \\
2 & 5 \\
1 & 3 & 3 \\
\hline
\end{tabular}

\begin{tabular}{lll}
7 & 1 & 3 \\
7 & 2 & 1 \\
7 & 2 & 3 \\
\hline & 1 & 3
\end{tabular}

\begin{tabular}{lll}
7 & 2 & 3 \\
\hline 5 & 2 & 2
\end{tabular}

$\begin{array}{lll}5 & 2 & 2 \\ 5 & 2 & 2\end{array}$

$\begin{array}{lll}1 & 7 & 5\end{array}$

$\begin{array}{llllll}1 & 7 & 7 & 5 & 5 & 3 \\ 2 & 3 & 5 & 3 & 5 & 4 \\ 1 & 3 & 5 & 3 & 5 & 4\end{array}$

1
2
1

$\begin{array}{ll}5 & 5 \\ 3 & 3 \\ 3 & 7\end{array}$

$\begin{array}{lllll}1 & 3 & 5 & 3 & 5 \\ 2 & 5 & 7 & 3 & 5\end{array}$

\begin{tabular}{lllllllllllll}
1 & 5 & 7 & 3 & 7 & 3 & 2 & 8 & 7 & 7 & 5 & 6 & 1 \\
3 & 5 & 7 & 4 & 5 & 3 & 2 & 6 & 5 & 5 & 3 & 7 & 3 \\
2 & 5 & 3 & 4 & 1 & 2 & 3 & 5 & 3 & 3 & 5 & 6 & 1 \\
1 & 5 & 5 & 3 & 7 & 2 & 3 & 7 & 7 & 7 & 7 & 2 & 2 \\
\hline 1 & 5 & 5 & 4 & 3 & 2 & 2 & 5 & 5 & 5 & 3 & 7 & 1
\end{tabular}

$\begin{array}{lllll}3 & 5 & 3 & 1 & 5 \\ 5 & 5 & 5 & 1 & 5\end{array}$

\begin{tabular}{lll}
2 & 5 & 5 \\
3 & 5 & 5 \\
\hline
\end{tabular}

$\begin{array}{lll}5 & 2 & 2 \\ 3 & 2 & 3\end{array}$

$\begin{array}{lll}2 & 3 & 3 \\ 2 & 5 & 7\end{array}$

$\begin{array}{llll}4 & 7 & 7 \\ 3 & 3 & 3\end{array}$

$\begin{array}{lll}2 & 7 & 3 \\ 1 & 5 & 5\end{array}$

$\begin{array}{ll}5 & 5 \\ 5 & 5 \\ 5 & 5\end{array}$

$\begin{array}{lll}2 & 3 & 5 \\ 3 & 3 & 5\end{array}$

$\begin{array}{llll}4 & 3 & 2 & 2 \\ 5 & 1 & 3 & 2\end{array}$

\begin{tabular}{lll}
5 & 2 & 2 \\
\hline
\end{tabular}

$\begin{array}{lll}2 & 5 & 5\end{array}$

$\begin{array}{llllll}2 & 3 & 7 & 2 & 5 & 7 \\ 4 & 7 & 3 & 2 & 1 & 5\end{array}$

$\begin{array}{llllllll}1 & 5 & 5 & 5 & 5 & 4 & 2 & 5 \\ 1 & 3 & 3 & 5 & 5 & 3 & 3 & 5 \\ 2 & 5 & 7 & 5 & 5 & 3 & 2 & 3 \\ 2 & 1 & 5 & 3 & 5 & 4 & 2 & 3 \\ 2 & 3 & 3 & 5 & 5 & 1 & 2 & 5\end{array}$

\begin{tabular}{lll}
3 & 3 & 7 \\
4 & 3 & 7 \\
\hline & 3 & 5
\end{tabular}

$\begin{array}{ll}5 & 1 \\ 4 & 7\end{array}$

\begin{tabular}{lll}
3 & 5 & 3 \\
2 & 3 & 3 \\
\hline
\end{tabular}

\begin{tabular}{lll}
3 & 3 \\
3 & 3 & 5 \\
3 & 3 & 5 \\
\hline
\end{tabular}

$\begin{array}{lll}7 & 2 & 1\end{array}$

$\begin{array}{lll}1 & 5 & 3 \\ 2 & 3 & 5\end{array}$

\begin{tabular}{lll}
5 & 2 & 2 \\
5 & 2 & 2 \\
\hline & 2 & 3
\end{tabular}

$\begin{array}{llll}2 & 3 & 5 & 3 \\ 2 & 5 & 5 & 3 \\ 1 & 5 & 7 & 1\end{array}$

\begin{tabular}{lll}
3 & 1 \\
3 & 5 & 3 \\
\hline
\end{tabular}

$\begin{array}{llll}7 & 1 & 3 \\ 3 & 2 & 3\end{array}$

$\begin{array}{lll}3 & 5 & 3 \\ 7 & 3 & 5\end{array}$

\begin{tabular}{lll}
3 & 2 & 2 \\
\hline 5 & 2 & 3
\end{tabular}

$\begin{array}{lllll}5 & 3 & 3 & 7 & 3 \\ 3 & 5 & 1 & 7 & 7\end{array}$

$\begin{array}{lllll}2 & 1 & 3 & 5 & 5 \\ 2 & 5 & 5 & 7 & 3\end{array}$

$\begin{array}{llllll}3 & 1 & 2 & 5 & 3 & 2 \\ 5 & 1 & 3 & 3 & 7 & 4\end{array}$

$\begin{array}{ll}5 & 2 \\ 5 & 2 \\ 5 & 3 \\ 5 & 2\end{array}$

$\begin{array}{lll}2 & 3 & 6 \\ 2 & 3 & 7\end{array}$

\begin{tabular}{lll}
5 & 2 & 3 \\
\hline 3 & 2 & 3
\end{tabular}

$\begin{array}{lllllllllllllll}5 & 3 & 2 & 5 & 3 & 4 & 3 & 3 & 3 & 5 & 7 & 7 & 5 & 6 & 1 \\ 5 & 3 & 2 & 7 & 3 & 4 & 5 & 3 & 2 & 8 & 7 & 7 & 7 & 6 & 1 \\ 5 & 3 & 2 & 3 & 5 & 3 & 7 & 3 & 3 & 5 & 5 & 5 & 5 & 6\end{array}$




\section{7. melléklet. (folyt.)}

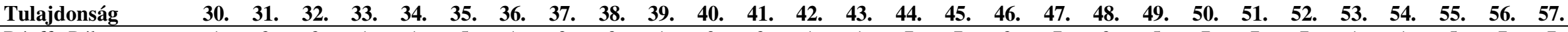

Bánffy Pál

Batul 1

Batul 2

Batul 3

Baumann renet

Beregi sóvári 1

Beregi sóvári 2

Börkormos renet

Budai Domokos

Budai Ignác

Cigány alma

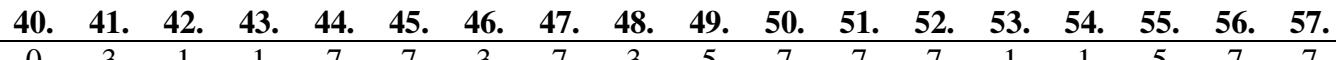

Cserepánya

Csíkos óriás halasi

Dániel féle renet

Daru sóvári

Édes escoar

Entz Rozmaring

Fekete tányéralma

Gegesi piros

Gomba Károly

Gyógyi piros

Harang alma

Herceg Batthyány

Hosszúfalusi

Húsvéti rozmaring

Ízletes zöld

Jászvadóka

Kanadai renet

Kanadai renet 2

Kanadai renet 3

Királyi renet

Kisasszony

$\begin{array}{lllll}1 & 3 & 3 & 1 & 1 \\ 1 & 5 & 3 & 1 & 1\end{array}$

$\begin{array}{ll}1 & 2 \\ 3 & 1\end{array}$

\begin{tabular}{lll}
1 & 5 & 3 \\
\hline 1 & 5 & 3
\end{tabular}

$\begin{array}{lll}1 & 5 \\ 1 & 5\end{array}$

$\begin{array}{lllllllll}2 & 5 & 5 & 2 & 1 & 5 & 5 & 3 & 5\end{array}$

\begin{tabular}{|c|c|c|c|c|c|c|c|c|c|c|c|c|c|c|c|c|c|c|}
\hline 1 & 0 & 3 & 1 & 1 & 7 & 7 & 3 & 7 & 3 & 5 & 7 & 7 & 7 & 1 & 1 & 5 & 7 & 7 \\
\hline 1 & 0 & 1 & 1 & 1 & 5 & 3 & 1 & 5 & 3 & 3 & 7 & 5 & 7 & 1 & 1 & 7 & 7 & 5 \\
\hline 1 & 0 & 1 & 1 & 1 & 5 & 3 & 1 & 5 & 3 & 3 & 7 & 5 & 7 & 1 & 1 & 5 & 7 & 5 \\
\hline 1 & 0 & 1 & 1 & 1 & 5 & 5 & 1 & 5 & 3 & 3 & 7 & 5 & 7 & 1 & 1 & 5 & 7 & 5 \\
\hline 2 & 3 & 2 & 1 & 1 & 7 & 7 & 3 & 5 & 7 & 3 & 7 & 3 & 3 & 2 & 1 & 7 & 5 & 6 \\
\hline 1 & 0 & 3 & 1 & 1 & 3 & 5 & 1 & 7 & 3 & 5 & 7 & 7 & 7 & 1 & 1 & 5 & 7 & 7 \\
\hline 1 & 0 & 1 & 1 & 1 & 7 & 5 & 3 & 7 & 3 & 5 & 5 & 7 & 7 & 4 & 1 & 5 & 7 & 6 \\
\hline 1 & 0 & 3 & 2 & 2 & 3 & 7 & 3 & 3 & 3 & 3 & 5 & 5 & 5 & 4 & 1 & 5 & 7 & 8 \\
\hline 3 & 3 & 1 & 1 & 1 & 3 & 3 & 3 & 5 & 5 & 3 & 5 & 7 & 7 & 1 & 1 & 7 & 7 & 5 \\
\hline 1 & 0 & 3 & 1 & 1 & 7 & 5 & 5 & 3 & 7 & 3 & 7 & 7 & 5 & 1 & 1 & 9 & 7 & 8 \\
\hline 1 & 0 & 2 & 1 & 1 & 3 & 3 & 1 & 7 & 5 & 5 & 5 & 7 & 5 & 3 & 1 & 5 & 5 & 7 \\
\hline 2 & 3 & 3 & 1 & 1 & 7 & 7 & 1 & 7 & 7 & 7 & 5 & 7 & 7 & 4 & 1 & 5 & 7 & 7 \\
\hline 3 & 7 & 1 & 1 & 1 & 7 & 3 & 3 & 7 & 7 & 7 & 7 & 7 & 3 & 2 & 2 & 7 & 5 & 5 \\
\hline 1 & 0 & 2 & 1 & 1 & 5 & 5 & 1 & 5 & 5 & 7 & 5 & 5 & 5 & 4 & 1 & 3 & 7 & 7 \\
\hline 3 & 5 & 1 & 1 & 1 & 3 & 3 & 7 & 5 & 5 & 5 & 5 & 5 & 3 & 1 & 1 & 9 & 7 & 8 \\
\hline 0 & 0 & 3 & 2 & 1 & 5 & 5 & 9 & 5 & 5 & 5 & 3 & 5 & 7 & 1 & 1 & 3 & 5 & 4 \\
\hline 1 & 0 & 1 & 1 & 1 & 3 & 3 & 3 & 5 & 7 & 3 & 5 & 3 & 7 & 1 & 1 & 5 & 7 & 9 \\
\hline 2 & 5 & 3 & 1 & 1 & 3 & 5 & 3 & 5 & 5 & 7 & 7 & 7 & 5 & 4 & 1 & 3 & 7 & 8 \\
\hline 2 & 7 & 1 & 1 & 1 & 7 & 3 & 1 & 7 & 3 & 7 & 7 & 5 & 5 & 3 & 3 & 7 & 7 & 7 \\
\hline 1 & 0 & 1 & 1 & 1 & 7 & 7 & 3 & 7 & 7 & 7 & 7 & 7 & 7 & 4 & 1 & 7 & 5 & 4 \\
\hline 2 & 5 & 1 & 1 & 1 & 5 & 7 & 3 & 7 & 5 & 3 & 3 & 3 & 3 & 3 & 1 & 5 & 5 & 4 \\
\hline 2 & 5 & 1 & 1 & 1 & 5 & 5 & 5 & 5 & 5 & 3 & 7 & 3 & 5 & 4 & 1 & 9 & 7 & 9 \\
\hline 0 & 0 & 2 & 2 & 1 & 7 & 7 & 3 & 7 & 7 & 5 & 5 & 5 & 3 & 3 & 1 & 5 & 7 & 7 \\
\hline 5 & 7 & 3 & 1 & 1 & 3 & 5 & 1 & 5 & 5 & 3 & 7 & 7 & 3 & 1 & 1 & 3 & 3 & 4 \\
\hline 1 & 0 & 1 & 1 & 1 & 5 & 3 & 3 & 5 & 7 & 3 & 5 & 3 & 7 & 1 & 1 & 5 & 7 & 9 \\
\hline 2 & 3 & 2 & 1 & 1 & 7 & 5 & 3 & 5 & 5 & 5 & 7 & 7 & 7 & 1 & 1 & 5 & 7 & 9 \\
\hline 1 & 0 & 1 & 1 & 1 & 5 & 5 & 5 & 5 & 5 & 5 & 5 & 3 & 7 & 1 & 1 & 1 & 3 & 4 \\
\hline 2 & 3 & 3 & 3 & 3 & 7 & 7 & 3 & 7 & 7 & 3 & 7 & 3 & 7 & 2 & 1 & 5 & 7 & 8 \\
\hline 2 & 3 & 3 & 3 & 3 & 7 & 7 & 3 & 5 & 7 & 3 & 7 & 3 & 7 & 1 & 1 & 5 & 7 & 8 \\
\hline 2 & 3 & 3 & 3 & 3 & 7 & 7 & 3 & 5 & 7 & 3 & 7 & 3 & 7 & 1 & 1 & 3 & 7 & 8 \\
\hline 4 & 5 & 3 & 1 & 1 & 5 & 3 & 3 & 7 & 5 & 5 & 5 & 3 & 5 & 1 & 1 & 5 & 5 & 7 \\
\hline 1 & 0 & 2 & 1 & 1 & 7 & 5 & 5 & 7 & 5 & 3 & 7 & 7 & 3 & 1 & 1 & 5 & 5 & 5 \\
\hline 5 & 7 & 3 & 1 & 1 & 5 & 7 & 5 & 7 & 7 & 3 & 5 & 5 & 5 & 4 & 1 & 5 & 7 & 6 \\
\hline
\end{tabular}




\section{7. melléklet. (folyt.)}

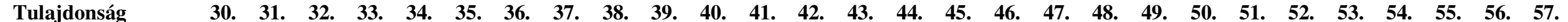
Lóci édes almája

Londoni pepin

Marosszéki piros

Masánszki

Máté Dénes

Mosolygós batul

Nemes sóvári

Nemes szercsika

Nyári fontos

Ontario

Orbai alma

Sándor cár $\begin{array}{llllllllllllllllllllllllllllllllll}1 & 5 & 5 & 1 & 3 & 3 & 1 & 3 & 3 & 2 & 5 & 1 & 1 & 1 & 3 & 7 & 1 & 7 & 7 & 3 & 7 & 7 & 3 & 1 & 3 & 3 & 5 & 6 \\ 3 & 5 & 7 & 2 & 2 & 3 & 1 & 1 & 3 & 1 & 0 & 2 & 1 & 1 & 3 & 5 & 5 & 7 & 7 & 5 & 5 & 5 & 5 & 1 & 1 & 7 & 7 & 8\end{array}$

Sárga szépvirágú

Sikulai

Simonffy piros

Sóvári nobil

Szabadkai szercsika

Szászpap alma

Széchenyi renet

Tartós Gusztáv

Tordai alma

Tordai piros kálvil

Tükör alma

Vajki alma

Vilmos renet

Zöld batul

Zöld sóvári

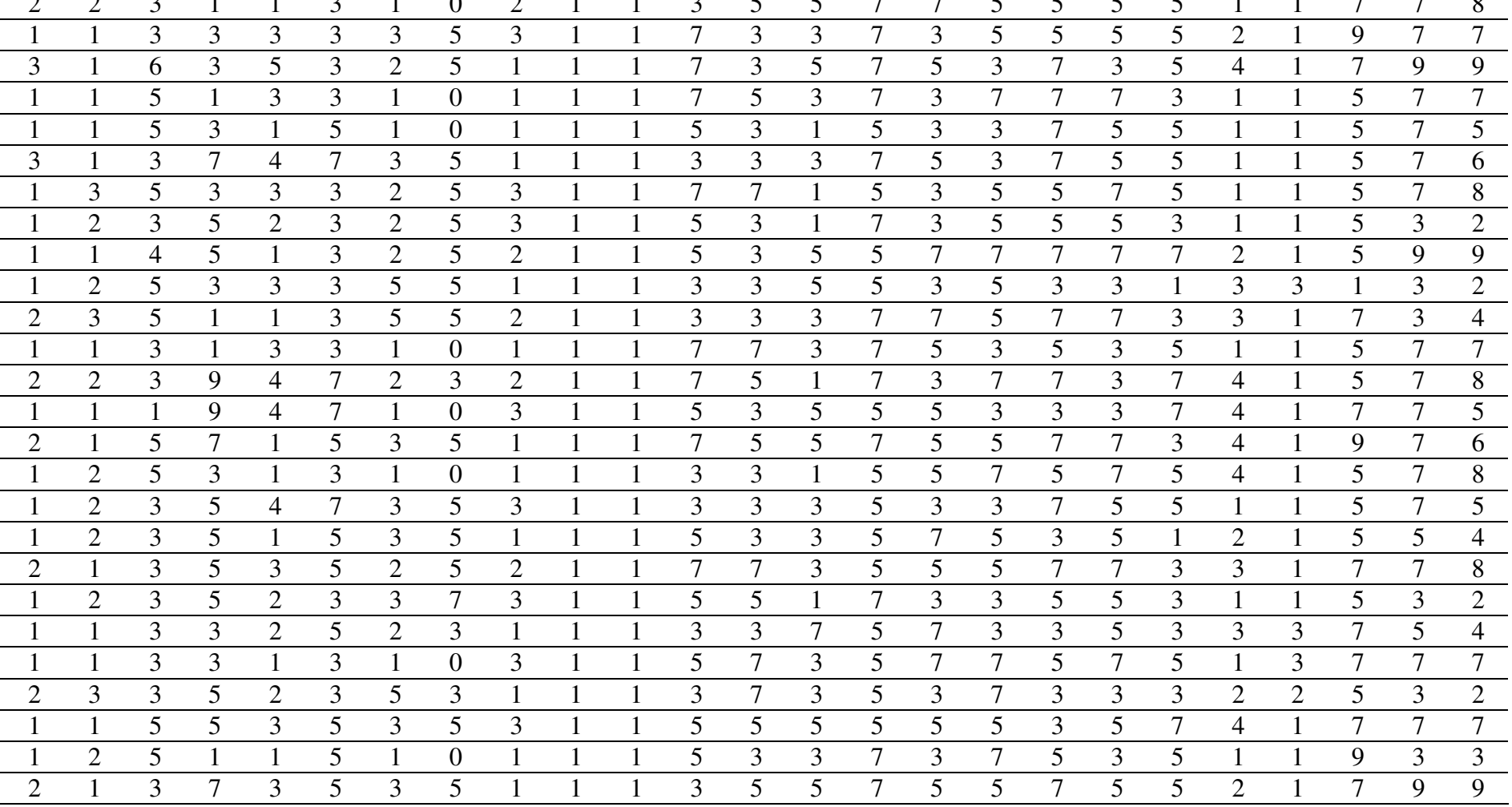


8. melléklet. Az UPOV számkulcsokból készített hasonlósági mátrix (a fajták páronkénti összehasonlításával képzett normalizált értékek összege)

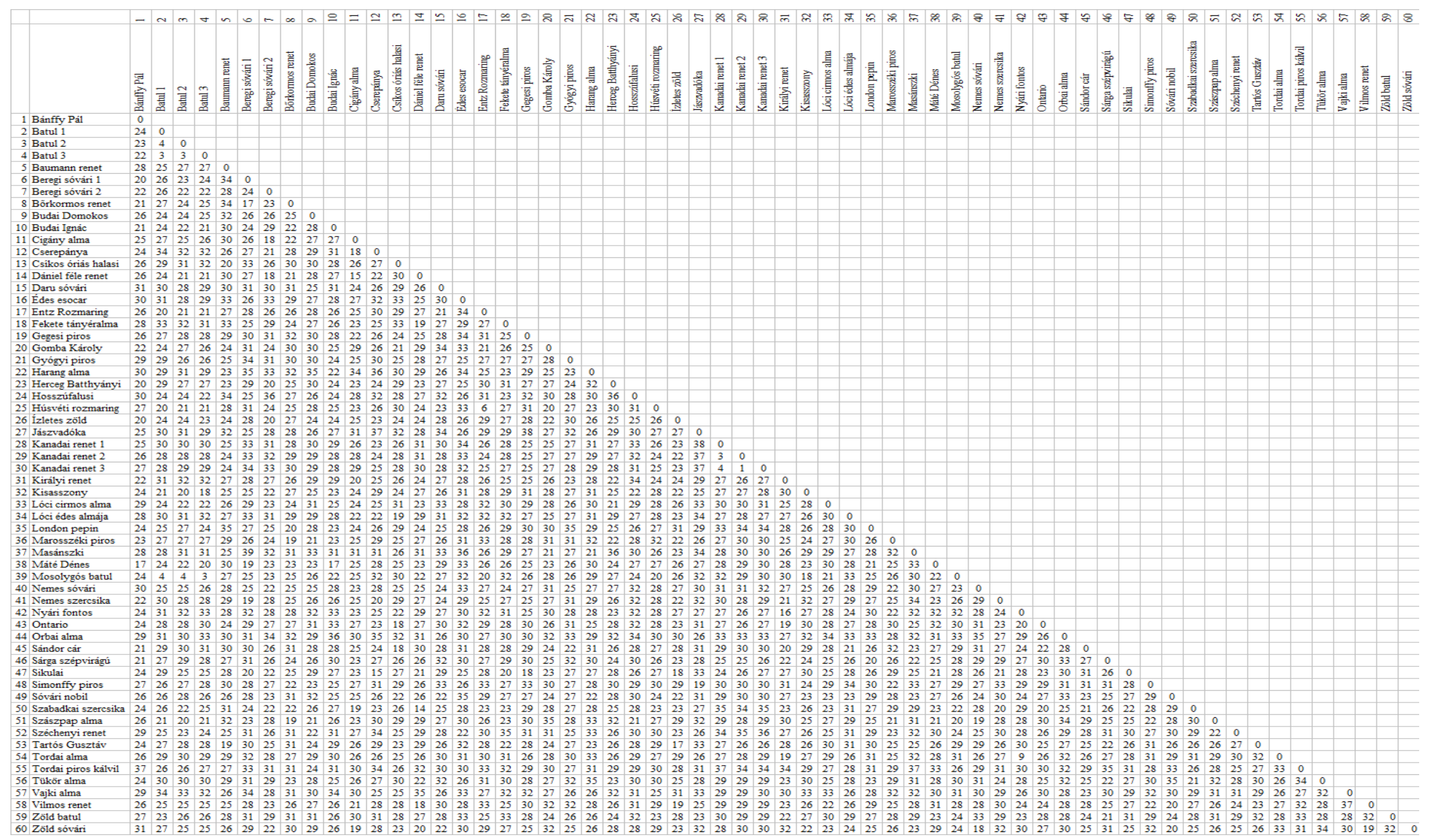




\section{9. melléklet. A fajták SSR fragmentumjai alapján készített Jaccard-indexen alapuló genetikai távolság mátrix}

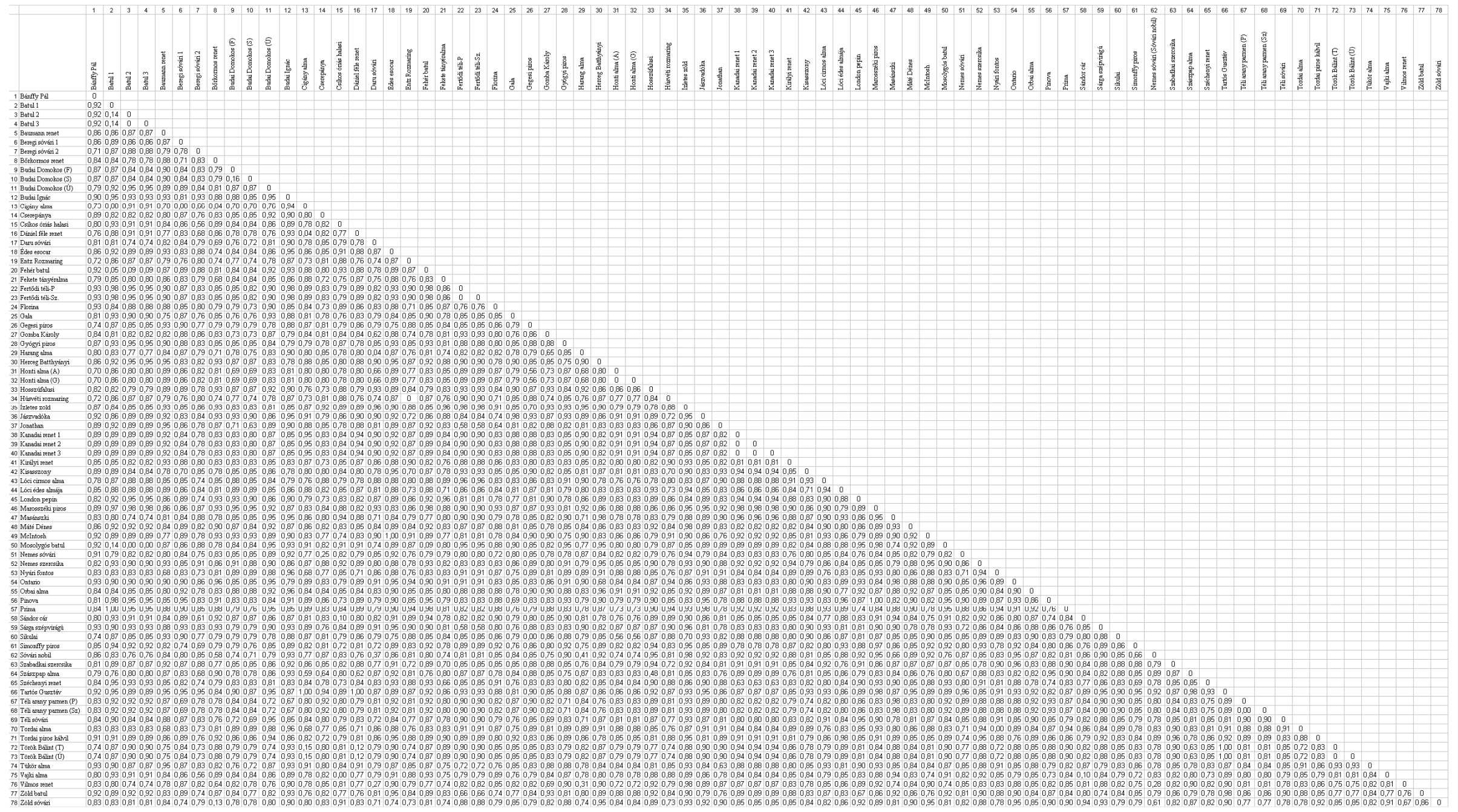




\section{KÖSZÖNETNYILVÁNÍTÁS}

Köszönöm témavezetőm, Dr. Tóth Magdolna segítségét a vizsgálatok elvégzéséhez szükséges háttér biztosításáért, és a dolgozat elkészülésében nyújtott szakmai és emberi támogatásért.

Köszönet Dr. Ladányi Mártának a statisztikai elemzésekekben nyújtott segítségért.

Köszönöm Dr. Pedryc Andrzej, Dr. Bisztray György Dénes, Dr. Halász Júlia, Dr. Deák

Tamás és Dr. Bodor Péter hasznos tanácsait az SSR vizsgálatok elvégzése során.

A vizsgálatok elvégzését a TÁMOP 4.2.1./B-09/01/KMR/2010-0005, VM-É-45343 és GOP1.1.1-09/1-2009-0042 pályázatok támogatták. 